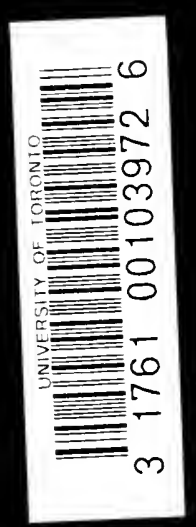






\section{Digitized by the Internet Archive in 2007 with funding from Microsoft Corporation}





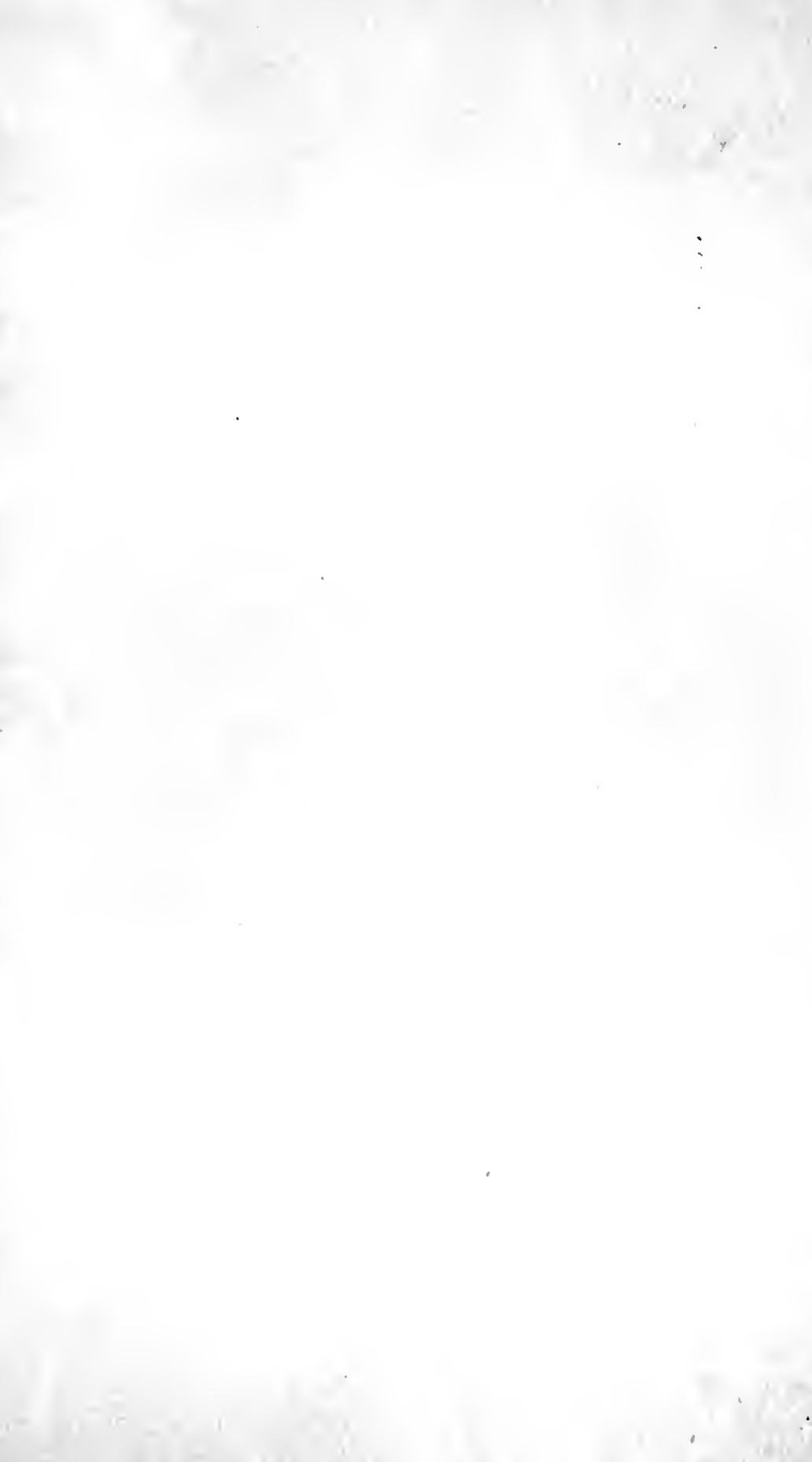
Mirabeau and the French Revolution By Fred Morrow Fling, Ph.D.

Three volumes, 8ro, Illustrated

1. The Youth of Mirabeau.

2. The Opponent of Arbitrary Government.

3. The Defender of the Constitutional Monarchy. 



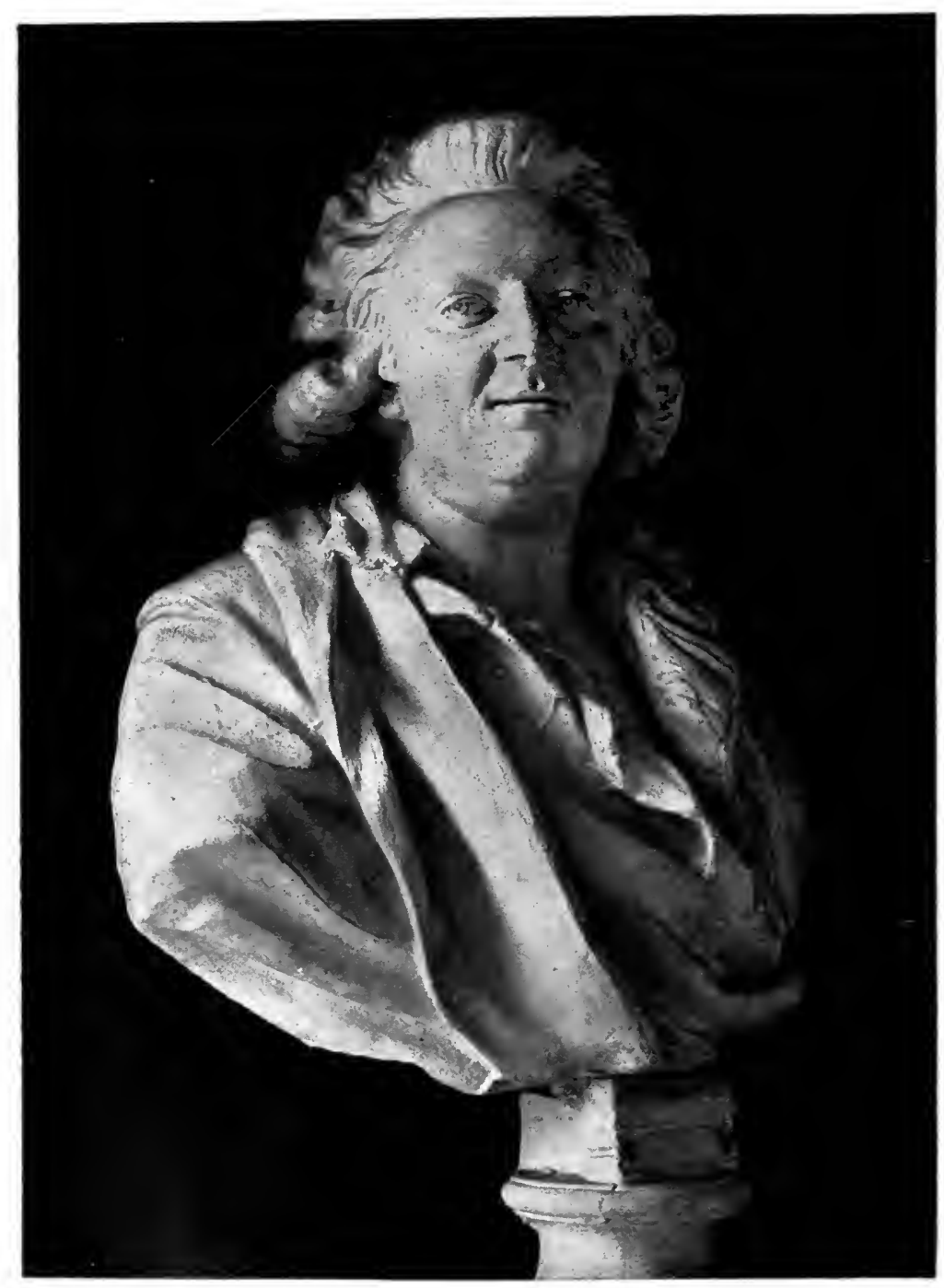

Mirabeau at Thirty

From the bust by Lucas de Montigny. Original in the possession of M. le Comte O'Mahony 


\title{
Mirabeau and the French Revolution
}

\author{
By \\ Fred Morrow Fling, Ph.D. \\ Professor of European History in the University of Nebraska
}

In Three Volumes

Volume I.

The Youth of Mirabeau

Illustrated

G. P. Putnam's Sons

New York and London

Tbe Rutckerbocker Dress

1908

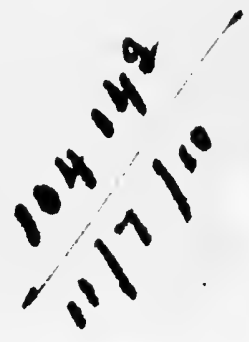


Copyright, Igo8 BY

FRED MORROW FLING

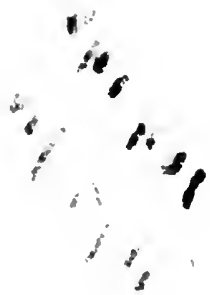

Tbe Knickerbocker Dress, Hew Dork 
TO MY WIFE

HELENE DRESSER FLING 


$$
\text { ' }
$$




\section{PREFACE}

THE plan of writing a life of Mirabeau was formed nineteen years ago in my student days at Leipzig. France was preparing to commemorate the centenary of the Revolution and I naturally turned to this period for the subject of my doctor's dissertation. Mirabeau as the central, dramatic figure of the early revolution attracted and fascinated me. At that time, neither the biography of $M$. Charles de Loménie nor that of Professor Stern had appeared and the subject seemed to promise rich returns for faithful effort. The very year in which I began my investigations, Professor Stern published his first volume; before my research had been carried far, M. de Loménie had completed his exhaustive work. I did not feel, however, that my occupation was gone, for there was still in English no full and scholarly life of Mirabeau, and that alone seemed sufficient justification for the continuance of the undertaking.

The work, as I have planned it, will consist of three volumes. The first volume is devoted to the youth of Mirabeau and closes with the year I774, when he legally came of age; the second will follow his fortunes during his confinement in French prisons, as a victim of lettres de cachet, and during the period of his activity as a publicist and of his residence in Holland, England, and Germany, ending in $\mathrm{I} 888$ with the preparations for the elections to the states-general; the third will deal 
with Mirabeau and the national assembly, describing his double rôle of leader of the assembly and adviser of the king, until his death in April, I79I. These divisions seem natural ones, including well marked phases of Mirabeau's life: (I) His youth; (2) his public career to the beginning of the revolutionary crisis and, finally, (3) his activities in the assembly.

As the title of the whole work, Mirabeau and the French Revolution, indicates, I have conceived my task in a large way and have striven to write the life of Mirabeau with an historical setting that will make it intelligible. I have endeavoured to present Mirabeau as a true heir of the Riqueti, as a product of Seighteenth century France, but possessing a marked individuality and reacting upon his environment as a leader in the greatest revolution of modern times. In narrating his life, I have tried to avoid the rôle of an advocate and to attain to a strictly scientific point of view. I have sought to describe his life as it actually was-in so far as the evidence permits it,-but to describe it sympathetically. This effort to reach an objective view of the man has determined the form of exposition. My aim has been-the aim, undoubtedly, of every conscientious historian who works consciously-not to stand more than is absolutely necessary between the reader and the evidence and, as far as possible, to reveal in the text the nature and value of the evidence. To introduce into the text the actual words of the Marquis, the Bailli, or the Comte de Mirabeau gives local colour to the narrative, and makes it possible for the reader to visualise these individuals in a way and to a degree that would be impossible from a narrative composed solely of the 
writer's interpretations of these words. As the visualisation of persons is one of the chief ends that the biographer has in view, this alone would seem to justify the weaving together of source extracts, but the method has the further merit of placing the evidence directly before the reader, thus enabling him to correct false interpretations and to detect and guard against prejudice in the historian.

Desirous of making my work reasonably complete, I have acquainted myself with the printed and manuscript sources, as well as with the biographies dealing with Mirabeau's life. Of the printed works of any value, but few are now missing from the library that I have brought together; during several visits to Europe, I have been able to examine the most of the manuscript material and to view the places connected with Mirabeau's life. This research work abroad has left behind it a train of delightful recollections. Had this volume never seen the light, the years of labour spent in its preparation would have been amply repaid by the warm friendships it has enabled me to make in Europe and especially in France. My feelings toward the French people have been revolutionised by the unspeakably kind reception I have ever met with at the hands of French scholars, both in Paris and in the provinces, while in the other European countries into which my investigations have taken me I have received convincing proof of the existence of a brotherhood of scholars. The names of Charles de Loménie, Alfred Stern, Georges Guibal, Paul Cottin, Dauphin Meunier, and Alexandre Mouttet are familiar to every student of Mirabeau's life. To each and all of them I am under obligations for their interest in my work, for their readiness to further my investigations, for the 
generous loan of books, manuscripts, and notes, and for helpful suggestions and criticisms.

Of the names that I have mentioned, one must be set aside from all the rest. Alexandre Mouttet is no longer among the living. A kindlier nature than his I have never known. During my summer at Aix, I grew deeply attached to him, for he treated me like a son, making the success of my investigations his personal concern. He permitted me to take home to America the manuscript of his unpublished volume on Mirabeau as well as a large collection of copies of manuscript letters. More than one chapter of this volume shows how great are my obligations to him.

Besides these students of Mirabeau's life, there are others whose names must be mentioned here because of their sympathy and assistance. Mr. Henry Vignaud, the distinguished historian and veteran secretary of the American embassy at Paris, smoothed my way into archives, libraries, and fortresses, and followed my labours with scholarly interest; M. Paul Arbaud, the liberal patron of Provençal historians, placed unreservedly at my disposal his unpublished and unutilised Mirabeau manuscripts and portraits; M. Henri Aubert, the nephew of M. Mouttet, has been good enough to allow me to retain until the present time the manuscripts of his uncle. My chief obligation for the use of manuscript material is to M. de Montigny of Aix, the grandson of the adopted son of Mirabeau. During my summer at Aix, he kindly permitted me to examine the twelve folios containing the manuscript copies of the several thousand letters that passed between the Marquis and the Bailli. They constitute the most important source of information for this volume. In conferring this favour upon an American 
scholar, M. de Montigny was but continuing the admirable tradition, established by his grandfather and kept alive by his father, of opening their manuscript treasures to historians. Two generations of scholars have profited by this generosity.

I would that I might mention here the names of all those who have aided indirectly in my investigations, or who have made my task a pleasant one while on the continent, the kind and unselfish natures whom I met in Paris, or at Aix, on the Ile de Ré, at Saintes, Mirabeau, Manosque, or Neufchâtel. They taught me many things that have not found their way into this volume, and left me with a fund of delightful memories that has proved to be the best reward for my labours.

But the labour has not been all my own. Long as this volume has been in assuming tangible form, it would have been still longer in appearing, perhaps never would have taken shape, had it not been for the patient and untiring assistance of my wife, who, in libraries and archives, has worked faithfully at my side. Her good judgment has been helpful to me throughout the construction of the volume and in the final reading of the text, while the French notes have especially profited by her careful inspection. The work is dedicated to her in memory of the long years of common effort that has produced it, as an act of simple justice and as a meagre expression of all that her companionship has meant to me.

LiNCOLN, NeBRASKA.

May $30,1907$. 



\section{CONTENTS}

\section{CHAPTER I}

The Struggle against Arbitrary Government

PAGE in France $\quad . \quad$. $\quad . \quad$. $\quad$.

CHAPTER II

The Origin and Rise of the Rigueti • • • 25

CHAPTER III

The Chevalier and the Bailli de Mirabeau • 43

CHAPTER IV

The Youth of the Marquis de Mirabeau • • 53

CHAPTER V

Matrimonial and Other Speculations • • 68

CHAPTER VI

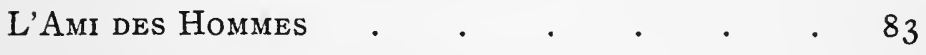

CHAPTER VII

L'Enfant Terrible • • . • • . 26

CHAPTER VIII

AN UNHAPPY FAMILY

CHAPTER IX

Monsieur de Pierre-Buffière • • • • • 175

$\mathbf{x i}$ 
xii

Contents

CHAPTER X

Monsieur de Pierre-Buffière (Continued) .

CHAPTER XI

Mirabeau in the Confidence of His Father

CHAPTER XII

The Marriage of Mirabeau • • • • 306

CHAPTER XIII

Extravagance, Debts and a Critical Situation • $33^{\circ}$

CHAPTER XIV

Lettres de Cachet and Interdiction • • • 365

CHAPTER XV

Two Affairs of Honour $\quad . \quad$. $\quad . \quad \cdot \quad 412$

CHAPTER XVI

The "Essay upon Despotism" . . . . 447

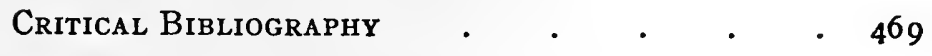

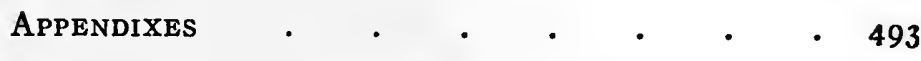




\section{ILLUSTRATIONS}

Mirabeau at Thirty . . . Frontispiece

PAGE

Bust by Lucas de Montigny. Original in the possession of M. le Comte O'Mahony.

Chateau de Mirabeau (from the west) . . 26

Photograph by the author.

Marquis de Mirabeau $\quad . \quad$. . . . 44

Painting by Thérèse Boucher ( $78 \mathrm{r}$ ).

Bailli de Mirabeau . . . . . . 50

Painting by Aved ( 748 ).

Birthplace of Mirabeau at Bignon . . . i 26

From Pallain, "La Statue de Mirabeau" (Paris, r 883).

Residence of Mirabeau at Saintes . . . 192 Photograph by H. D. Fling.

Palais de Justice at Saintes . . . . 202 Photograph by H. D. Fling.

Residence of Mlle. de Marignane at Aix . . 308 Photograph by H. D. Fling.

Looking East from the Chateau de Mirabeau • 340 Photograph by H. D. Fling.

Residence of Mirabeau at Manosque . . 380 Photograph by H. D. Fling. 
“Mirabeau, excellent citoyen, qui toute ta vie n'as cessé de signaler ta haine contre le despotisme et as contribué plus que personne à nous affranchir."

Camille Desmoulins, La France Libre (1789), io.

"C'est le plus étrange mélange de bien et de mal que j'aie connu."

Du Pont De Nemours, quoted by Schelle, Du Pont de Nemours, 20. 


\section{MIRABEAU AND THE FRENCH REVOLUTION}

CHAPTER I

THE STRUGGLE AGAINST ARBITRARY GOVERNMENT

IN FRANCE

$\mathrm{F}^{\mathrm{ROM}}$ the shifting background of human affairs that somehow become history, figures here and there detach themselves and fix the attention. They are the shapes of men whose activities were so closely identified with the serious business of their day that their deeds became historical events and their biographies take on the importance of universal history. Such a man was Mirabeau.

The movement with which his life was identified was the revolt against arbitrary power and the attempt to establish a government based upon law that filled the eighteenth century of French history. It culminated in the meeting of the states-general, in the transfer of sovereignty from the monarch to the middle class and in the formation of the Constitution of I79I. Viewed as a crisis in this struggle, the events of I $_{7} 8$ become pregnant with meaning and the oath of the tennis court assumes the significance of a world event. Looked at in an even more comprehensive vor. $1=x$ 
way, the French Revolution appears as a part of that larger movement that gave to England its Bill of Rights, to the American colonies their independence and to many states constitutional government. Mirabeau was thus a fellow labourer with Franklin.

Only when thus broadly conceived does the work of Mirabeau's life become intelligible. It is a false perspective that sees in the national assembly more historical significance than in the century of agitation against arbitrary power that made the assembly possible; that dates the beginning of Mirabeau's historical life from his entrance into the states-general and not from the year of the publication of his Essai sur le despotisme. The first event marked the culmination, the last the beginning of his activities as an historical character.

At the opening of the eighteenth century, the government of France was arbitrary both in theory and in practice. During his long reign, Louis XIV. tolerated no resistance to his will and at the end of his life formulated the theory of absolutism for the benefit of his successor. "It is to the head alone," he wrote, "that the power of deliberating and determining belongs and all the functions of the other members consist only in the execution of the commands which are given them." The king was not only the sole legislator, but he ruled by divine right, was responsible alone to God and demanded passive obedience from his subjects. The theory corresponded to the fact.

At the close of the century, both the theory and the practice had radically changed. The king had been stripped of his power and the national assembly had become omnipotent, while the Declaration of Rights and the Constitution of $179 \mathrm{I}$ contained the new theory 


\section{Struggle Against Arbitrary Government}

of the sovereignty of the nation. Between these two extremes lies the reign of Louis $\mathrm{XV}$., a period of agitation and transformation.

How this transformation was wrought is an historical problem of the first importance. Until the appearance of the works of Aubertin and Rocquain, the most generally accepted explanation attributed the change almost exclusively to the influence of a powerful public opinion, created by the writings of the so-called philosophers. ${ }^{1}$ It is now known that this explanation is both incomplete and inexact. It overlooks the fact that one generation of agitators had nearly passed from the scene before the philosophers began to write, and it fails to take into account what is, perhaps, the most important factor in the whole movement prior to 1789 , the parliaments of France. ${ }^{2}$

It was the parliaments of France that precipitated the revolution by forcing Louis XVI. to convoke the states general. This act was the last in the long struggle between an arbitrary government and the remnants

1 Aubertin, Charles, L'esprit public au XVIII' siècle. (Troisième édition. Paris, 1889,258$)$ : “Les philosophes n'ont pas droit à une part si large dans le mérite ou la responsabilité de l'évènement; en admettant qu'ils aient été les ouvriers les plus énergiques des changements accomplis, ils n'en sont ni les seuls ni les plus anciens promoteurs."

2 After quoting the statement of D'Argenson that the parliaments by their studies had established the opinion that "the nation is above kings" Aubertin remarks: "Voilà donc un point bien établi: le principe fondamental de la révolution est sorti des luttes politiques du XVIII siècle et non des spéculations de la philosophie." Ibid., 275. In June, $175^{2}$, D'Argenson, after giving an account of what the "gazette manuscrite de Cologne" said of the struggle between the king and the parliament-"elle ne parle que des cris de joie qu'en a poussés le peuple; elle dit que le parlement dispute au roi son autorite"-describes the rôle played by the parliament and adds, "En un mot, c'est le seul organe du peuple qui puisse se faire entendre aujourd'hui." D'Argenson, vii, 243. 
of independent institutions in France. The profound disrepute into which the parliaments fell after 1788 has blinded historians to the great significance of the part they played prior to that date. How the revolution could ever have been accomplished without the aid of these bodies, it is not easy to imagine. Failure to take the parliaments into account in dealing with the causes of the great transformation, explains the current but incorrect conception that the revolution was the work of pure theorists and had no foundation in historical tradition. It would probably be much nearer the truth-although not the whole truth-to say that the agitation that led to the assembly of the states-general was but the conclusion of the struggle between the monarchy and the privileged orders in which the parliamentary Fronde of the preceding century had been an episode.

However selfish and reactionary the motives of the parliaments may have been, their opposition certainly tended to check the arbitrary acts of the ministers and naturally received the support of public opinion, that, not without reason, regarded the parliaments as the last bulwark of the nation against despotism. They were the only bodies in France capable of playing such a part and it is extremely doubtful if even they could have played it under a masterful king. ${ }^{1}$ For the success or failure of the opposition depended upon the attitude of the king and his ministers toward the

" "Un des plus éclairés, dit Duclos, et des plus zélés parlementaires, à qui je demandais de me marquer précisément les bornes qui séparent l'usurpation d'avec le droit des parlements, me répondit: Les principes en cette matière sont fort obscures; mais, dans le fait, le parlement est fort sous un roi faible et faible sous un roi fort." Quoted by L. de Loménie, Beaumarchais et son temps (Deuxième édition, Paris, 1858), i. 308. 


\section{Struggle Against Arbitrary Government 5}

public sentiment aroused by the remonstrances of the parliaments or by the suspension of justice throughout France.

From first to last, the parliaments opposed the government on a variety of questions, but the differences arose chiefly over ecclesiastical and financial affairs, and in both the vast majority of the nation was on the side of the opposition.

The attempt to force the famous Constitution on the French church, was followed by a half century of agitation that stirred society to its depths. The parliament of Paris, supported by public opinion, resisted this effort to destroy the cherished "Gallic liberties," but in spite of its remonstrances it was compelled by Louis XIV. to register the bull. Under the liberal government of the Duc d' Orléans, the strife was renewed and ended only with the expulsion of the Jesuits and the victory of the parliaments and their supporters. The government suffered much from this affair. Its repeated orders that all discussion should cease were not obeyed; its attempts to interfere upon the one side or the other aroused the antagonism of the injured party and frequently led to a discussion of the powers of the monarch. A despotic government, throwing its protection over a despotic clergy, shared inevitably the odium that the public entertained for the supporters of the Constitution and the right of such a government to deal arbitrarily with the affairs of the church was naturally questioned. ${ }^{1}$

1 The subject is treated at length and with an abundance of quotations from the sources in Rocquain, F., L'esprit révolutionnaire avant la révolution (Paris, I878), $\mathrm{x}-23 \mathrm{I}$. See, also, Aubertin, Charles, L'esprit public au XVIII' siècle (Troisième édition, Paris, 1889 ), 258-296. The principal sources are: Marais, Mathieu, Journal et mémoires (4 vols., Paris, 1863); Barbier, 
Matters of finance were, however, the most prolific cause of trouble between the king and the parliaments. No new taxes could be levied, no money could be borrowed, until the edicts had been registered. Posing as the guardian of the interests of the nation in times of famine and of suffering, the courts often remonstrated against an increase of taxes or of debt and refused to register the royal edicts. If the king forced the registration-a not uncommon occurrence-the parliaments sometimes went so far as to forbid the taxpayers to pay the tax and to prohibit the tax collectors from collecting it on pain of capital punishment. ${ }^{2}$ In the last half of the century, the courts even attempted, at times, to play the rôle of the English Parliament. When tax edicts were sent to them for registration, they demanded a statement of receipts and expenses that they might be convinced that the wants of the government were legitimate. ${ }^{2}$

More important, possibly, than the causes of the conflict between the king and the courts was the fact that such a conflict existed. Not only did this long struggle destroy the prestige of the government and undermine its authority, but it led to the denial of the claims of the monarchy as formulated by Louis XIV. The constant strife created, kept alive and developed a public

E. J. F., Journal (8 vols., Paris, I 866); D'Argenson, René, Mémoires (9 vols., Paris, 1859); Isambert, Recueil général des anciennes lois françaises ( 30 vols., Paris, I821-1833), vols. xxi., xxii.; Flammermont, Jules, Remontrances du parlement ide Paris au XVIII' siècle (3 vols., Paris, $1888-1896$ ), vols, i, ii.

1 "Le parlement de Besançon (Franche-Comté) a été en grand mouvement pour empêcher la levée de la taxe en forme de don gratuit. Défenses de la percevoir à peine de mort et des procédés violents contre $M$. de Boynes, intendant de la province et premier président."-Barbier, vii., r 26, February, 759.

2 Barbier, V., 227 ; Flammermont, Remontrances, ii., 277. 


\section{Struggle Against Arbitrary Government 7}

opinion that was finally powerful enough to enable the parliaments to bring the king to terms.

At first sight, the contest appears to be an unequal one. Matched against an arbitrary government with an armed force at its disposal, the resources of the parliaments seem paltry indeed. Many times, in fact, they were utterly inadequate, but on the whole they were very effective. The credit of the government suffered when it was obliged to force the registration of financial edicts and French society was seriously disturbed when the parliaments refused to try cases. These were, seemingly, intangible weapons, but the government could not always stand against them. How far the parliaments carried their resistance depended upon the temperament of the members, the temper of the government, and the state of public opinion. At times, they went no further than a simple remonstrance against an edict and obeyed without discussion the peremptory order to register; at other times, they yielded only in a lit de justice, while at still other times they remonstrated anew, annulled the edicts of the grand council, refused to administer justice, or even went so far as to forbid the officers of the provinces to execute the provisions of the obnoxious edict.

The methods employed by the government depended upon the amount of resistance encountered and its own determination to overcome it. Negotiations, orders to register, lits de justice, arrests of individual members, the exile of a whole parliament, diminution of the prerogatives of the parliaments, and even the destruction of the parliaments were the means resorted to by the government in its struggle with the courts. Sometimes none of the methods were successful and 
the recall of the banished parliament was an acknowledgment of the defeat of the government. ${ }^{1}$

While the parliaments formed the centre of the active opposition to arbitrary power, both in the church and in the state, yet neither in the reasons they advanced nor in the ends they aimed at did they have much in common with the critics of the ancient régime, the men who shaped public opinion in the latter half of the century. Both wished to limit the power of the monarch-so much they had in common-but the parliaments would have limited it in the interest of the privileged classes, the reformers in the interest of the whole nation.

Although influenced by selfish and reactionary motives, the parliaments posed as the defenders of the rights of the nation and supported these claims by appeals to the ancient laws of France. As these citations from royal edicts and parliamentary remonstrances were unfavourable to arbitrary power, they were equally acceptable to all groups of the political opposition. At no time in the history of the struggle did the parliaments employ, to any large extent, abstract arguments. That they could not wholly escape an influence that impregnated the atmosphere of the time is self-evident, but there is an essential difference between the writings of Rousseau and the documents issued by the parliaments. The latter stood, or pretended to stand, on historical ground. ${ }^{2}$ They

- Flammermont, Remontrances, i., Introduction. Flammermont's introductions to the three volumes of remonstrances taken together form an excellent short history of the struggle between the king and the parliament of Paris in the eighteenth century.

2 Of the truth of this position, the famous remonstrances of April 9, I 753, furnish the most convincing proofs. See Flammermont, Remontrances, i., 521-609. 


\section{Struggle Against Arbitrary Government}

demanded the observance of the old laws, the restoration of the old monarchy.

As early as 1730 , a pamphlet, condemned by the council of state, formulated the views that the parliaments were to defend in the long struggle against an arbitrary king. The publication was a consultation of forty advocates in behalf of a group of curés who had appealed to the parliament of Paris from the censure of their bishops. It was there asserted that the parliaments were the senate of the nation, the king, the chief of the nation. The parliaments were the sovereign depositories of the laws and no one was exempt from their decrees. This authority exercised by the parliaments was treated as having a representative character and no reference was made-so the council complained - to the fact that the prince is the source of all authority. The advocates even maintained that the laws were of the nature of contracts made between those who govern and those who are governed. "Such maxims" -remarked the council- "would hardly be tolerated in a republic; they are absolutely intolerable in a monarchy, despoiling the monarch of his quality of legislator, forcing him to treat as equal with equal with his subjects, by way of contract, and even exposing him to the danger of receiving laws from those to whom he should give them." 1

Here was a clear statement of the issue between divine right and popular sovereignty more than a generation before the appearance of the Contrat social. These ideas did not originate with Rousseau. The philosophers were not the authors of the revolution; on the contrary they but gave expression to an already existing public opinion. It is true, that when forced

' Rocquain, L'esprit révolutionnaire avant la révolution, 56, 57. 
to choose between a recantation and the loss of their offices the advocates recanted; but the time was not far distant when members of the parliaments, defending the same principles, would refuse to recant. Then the revolution was accomplished. It was simply a question of developing a public opinion sufficiently strong to make the resistance of the parliaments effective. This was to be the work of the next two generations.

Against the parliament of Paris, posing as a national senate, the king attempted to make use of the council of state. Cases were transferred to the council and decrees of the parliament were annulled. A pamphlet, published in $\mathrm{I}_{732}$ in the interests of the parliaments, condemned such acts as unconstitutional. "The king," the writer asserted, "may contract with his people only in the midst of his parliament, which, as ancient as the crown and born with the state, is the representative of the entire monarchy. The council of the king, a kind of jurisdiction established in defiance of the most fundamental laws of the kingdom, has no public character and it commits a manifest usurpation when it annuls or invalidates the decree of parliament. It matters little that the king is present in his council; he is present there only to destroy the laws; the rôle of the sovereign consists in maintaining them. It is his oath; it is the contract that he has made with his people. As he may make laws only with the concurrence of parliament, he ought to bear with its refusals and remonstrances. The magistrates who, in the face of the monarchy, would abandon the right to resistance, would be prevaricators in their functions and would become criminal." 1

1 Rocquain, L'esprit révolutionnaire avant la réolution, 69, 7०. 


\section{Struggle Against Arbitrary Government II}

Although the views in these pamphlets emanated from parliamentary circles, they were not the official utterances of the parliaments. It was in the remonstrances to the royal edicts that the parliaments officially made public their political ideas. They charged the king with violating the constitution of the kingdom, and added, "It is by alteration of the laws that revolutions are prepared." They declared that, "if subjects ought to obey kings, kings, in their turn, ought to obey the laws." 1 But what were the laws? Only those edicts that had been freely registered by all the parliaments of the kingdom. ${ }^{2}$ For one outcome of the struggle was to develop a feeling of common interests among the parliaments, and this feeling led to the formulation of the theory of the unity of the parliaments of France, the provincial courts being looked upon as classes or parts of one national court. The necessity of registering the edicts and the right of remonstrance possessed by the parliaments made them, they claimed, associates in legislation. " "The verification of the royal edicts," moreover, "did not mean blind approval of them." This was true to such an extent that the remonstrance formed an inseparable part of the edict. ${ }^{4}$ This theory had not been accepted

1 Rocquain, L'esprit révolutionnaire, I $7 \mathrm{I}$; Flammermont, Remontrances, i., 526 , note $\mathrm{I}$.

2 Rocquain, ibid., r 96, 242; Flammermont, ibid., ii., 274.

3 Rocquain ibid., 96, 222 ; Flammermont, ibid., 435

- Rocquain, L'esprit révolutionnaire avant la révolution, 142, 242; Flammermont, Remontrances, i., 466; Barbier, v., 73; D'Argenson, vi., 450. After quoting from the remonstrances the statement of the parliament that "les modifications portées dans les arrêts d'enregistrement en font essentiellement partie et en sont inséparables, suivant les anciennes maximes du royaume et les lois fondamentales de l'état," D'Argenson comments as follows: "Il sera nécessaire que, dans la réponse aux remontrances, le chancelier relève ces 
by the kings, but it had formed the working theory of the parliaments, especially under weak kings. In the past, edicts had been registered by force; in the future, the parliaments "would not recognise the authority of lits de justice and would accept as laws only those that had been freely consented to." 1 In registering his edicts by force, the monarch reduced the nation "to the humiliating condition of a subjugated people." But the subjects "of the king of the French," protested the parliament of Paris, "are free men and not slaves." 2

The members of the parliaments, the remonstrances declared, were "sacred and inviolable" and their exile by the king was a violation of "the rights that all citizens have of being punished only in conformity with the laws and after a judicial examination made by their natural judges." 3

Add to all this, the demands of the parliaments for financial statements and the declaration of the parliament of Paris that, before registering new tax edicts, it must be convinced that the sums turned into the treasury in past years " had really been expended for the service of the state" 4 and it is not difficult to see why the courts were suspected by contemporaries of wishing to play the rôle of the British parliament. ${ }^{5}$

maximes et, s'il les relève, voilà la chance pour définir l'autorité royale en France et celle du parlement et de toutes les cours souveraines. Voici que le parlement y intéresse toute la nation, les lois fondamentales du royaume et de l'état. Les étrangers jouiront de ce spectacle; l'Angleterre dira que le monarque est encore plus bridé chez nous que chez eux." See. also, in the same volume, pages 242, 253,271, 294, 369, 374, and 376 .

1 Rocquain, L'esprit révolutionnaire avant la révolution, 219.

2 Ibid., 243.

3 Ibid., 223.

4 Ibid., 2 I9, 24 I ; Flammermont, Remontrances, ii., 277.

5 Rocquain, L'esprit révolutionnaire avant la révolution, 2 I9. 


\section{Struggle Against Arbitrary Government I3}

Shrewd observers like D'Argenson realised the importance of such a rôle and the great possibilities that it contained. Commenting, in a letter to his brother, upon a correction made by the parliament of Paris in a royal edict, he said: "When the parliament acts thus, it not only attributes to itself a part in legislation, but a superiority to the king, since it annuls the proclamation of the law." He added that, two years before, the first president of the parliament, in an address to the king, had declared that "the modifications of (an edict by) the parliament form a part of legislation." This maxim D'Argenson considered both false and dangerous. He warned his brother, then one of the ministers of Louis XV., that this claim should not pass unchallenged. "It is thus that the commons of England advanced their usurpation over royalty by titles, charters, and usages. Originally, royalty in England was equal to that of France." 1

As a rule, however, he looked upon the parliaments as the last check upon arbitrary power. The monarch could be controlled, he believed, "by a refusal to grant money, as in England. Have we not the parliament of Paris, that calls itself the court of peers, and that suspends the will of the king?" 2 In another place, he speaks of the parliament as "a national senate all formed that may control the passions that I fear and may assure the safety of a nation against the absolute monarchical power." Finally he declared that the parliament was en règle in whatever it did; that it was composed of magistrates more difficult to corrupt than the members of the English parliament;

1 D'Argenson, Mémoires (edition of 1857,5 vols.), v., 58, 59, December 8, I 754 .

I Ibid., v., 293. 
that authority might strike them, but it could not intimidate or seduce them. "They oppose every new impost, refuse obstinately to register a loan, and dare to prescribe to the king to pay his debts with the funds that have been allotted to them before incurring new expenses." 1

Observations of a similar nature, extending over a series of years, might be drawn from other journals of the time. They were undoubtedly typical of the views of the majority of the nation. The parliaments were looked upon as the defenders of the rights of the people. So critical was the situation, that, in the words of Barbier, "If the authority and the pretended rights of the parliaments should be diminished, there would be no further obstacle to an assured despotism. If, on the contrary, the parliaments unite to oppose such attempts by strong measures, that can be followed only by a general revolution in the state." 2 Mably predicted the very steps that the parliaments would take to precipitate the revolution. ${ }^{3}$

Such claims were irreconcilable with the theory of divine right as formulated by Louis XIV. and accepted by his successor. In a letter, addressed by his minister in 1760 to the parliament of Rouen, Louis XV. rebuked the parliaments for their audacious language. He charged the magistrates with encroaching upon the rights of the monarch. The theory of a single national parliament, he treated as "new and chimerical." Above all, he combated the pretension of the parlia-

1 D'Argenson, Mémoires (edition of 1857,5 vols.), v., 295, 347, 348. December 8, I 754 .

2 Barbier, Journal, viii., 88, July I, I 763 .

3 Mably, Des droits et des devoirs du citoyen (Paris, 1893), x 19-133. 


\section{Struggle Against Arbitrary Government I5}

ments to regard as laws only those decrees that had received their adhesion. He charged them "to remember that his authority being sovereign, no one in his kingdom could share it with him. "You forget, and the parliament of Besançon has also forgotten," continued the minister, "that it is his majesty alone who forms the ordinances and the laws to which all subjects ought to submit. It is from him alone that the parliaments derive their existence and their powers. If the king sees fit to receive their remonstrances, it is not permitted to them under this pretext to suspend, still less to forbid, the execution of his orders. They ought to expect from his justice the reformation of the pretended abuses that they had denounced to him. Such are the veritable principles of the monarchy, unalterable principles that you are endeavoring to. destroy." 1

Six years later, the king in person expressed the same ideas, in a more vigorous form, to the parliament of Paris. After referring to the pretension of the parliaments to form an indivisible body, which was representative of the nation and participated with the monarch in the making of the laws, he said: "It is in my person alone that the sovereign power resides; it is from me alone that my courts derive their existence and their authority; it is to me alone that the legislative power pertains, without dependence and without division; the entire public order emanates from me." He concluded with the threat that, if the parliaments continued to offer "the scandalous spectacle of a rival of his sovereign power," he would be "reduced to the sad necessity of employing the power that he had received from God to preserve his

1 Rocquain, L'esprit révolutionnaire avant la révolution, 224. 
people from the unhappy consequences of similas enterprises." 1

This was the defiant answer of the monarchy by divine right to the new theory of the sovereignty of the law. The issue was fairly taken; the struggle that followed was to end only with the fall of the monarchy.

The French people were not indifferent to the outcome of a struggle that touched so directly their own interests. By the publication of their decrees and remonstrances, the parliaments appealed directly to public opinion, and met with a quick response. An enormous polemical literature sprang into existence and found eager readers. There were books and pamphlets, news-letters, songs, and poems. They dealt with all the phases of the many-sided discussion and were written in every conceivable vein from jest to earnest. ${ }^{2}$

Whatever may have been the real attitude of the parliaments, the makers of political history, toward the current political theories, they were dependent upon public opinion for support in their struggle with the monarchy. The government naturally endeav-

1 Flammermont, Remontrances, ii, 556-559. This session is famous in parliamentary history under the name of séance de la flagellation.

2 The remarkable activity of the press in the eighteenth century is a striking illustration of the profound gulf that may exist between the content of a law and the attitude of the government in the enforcement of the law or the possibility of enforcing it. Because the laws were severe, it has too often been inferred that the press was inactive. Rocquain notes (223, note 3 ) that the library of Besançon formed a collection of six volumes of the brochures that appeared in connection with the parliamentary episode of 1760 . And this was only one episode in the great struggle. See in Rocquain (489-535) the list of books condemned between I 7 I5 and I789. 


\section{Struggle Against Arbitrary Government I 7}

oured to deprive them of this support and its attempts to suppress discussion and to prevent the expression of public opinion form one of the most interesting features of this remarkably interesting period. Throughout the century, it strove to maintain a strict censorship over the press, but its success was not flattering. The reappearance, from time to time, of edicts upon the press was proof in itself of the inability of the government to deal successfully with the problem. The very contents of the edicts furnished convincing evidence of the failure of the censorship. ${ }^{1}$ Presses were seized or destroyed; authors were immured in the bastile; printers and colporteurs were placed in the stocks or sent to the galleys, while books and pamphlets were confiscated and many of them burned by the hangman. ${ }^{2}$ All these efforts were useless. The whole nation was in a conspiracy against the government.

As the century wore on, the situation grew ever more critical. More than once France seemed on the eve of a revolution. ${ }^{3}$ The claims of the king and of the parliaments were irreconcilable; clearly, one of them must subdue the other. The suppression of the parliaments had been considered and even threatened by the king, but not until $177 \mathrm{I}$ did he venture to resort to such an extreme measure.

It was on the occasion of the trial of the Duc d'Aiguillon by the parliament of Paris that Louis XV., acting

1 Anciennes lois, xxi., No. 255, Paris, Oct. 20, I 72 I; xxi., No. 372, Versailles, May 10, I728; xxii., No. 532, Versailles, March 31 , 1739; xxii., No. 547, 'Versailles, April II, r740; xxii., No. 673, Versailles, Feb. 7, 1752; xxii., No. 726, Versailles, April 16, I757; xxii., No. 865 , Versailles, March 28, I 764 .

Marais, Journal, iii., 577 ; iv., 8, I55, 163.

3 Rocquain points out $(287)$ that between 1752 and $177 \mathrm{I}$ the revolution threatened to break out three times.

vor. $1-2$ 
upon the advice of his unscrupulous minister, Maupeou, destroyed the old parliaments and removed the last check upon the arbitrary exercise of his will. ${ }^{1}$ The king put an end to the trial by letters patent and exculpated the duke. Affirming that justice had been outraged by this act, the parliament, by decree, deprived the duke of "all the rights and privileges of the peerage until he should have cleared himself of the suspicions that rested upon his honor." 2 This decree was annulled at once and a royal edict was issued, intended to define the limits of parliamentary activity and to anticipate further opposition on the part of the courts.

The edict was another declaration of absolutism. The preamble described in concise language the encroachments of the parliaments on the royal authority. They had suspended the administration of justice thinking to "constrain us to yield to their resistance"; at other times, "they had offered their resignations in a body, and by a singular contradiction, they have thereupon disputed our right to receive them"; they pretend that they compose "a single corporation, a single parliament, divided into several classes"; this new idea appears in their decrees in the expressions, classes, unity, indivisibility; they correspond with one another, send memoires and decrees, and adopt one another's judgments; they have "established maxims unknown up to the present time, calling themselves the 'representatives of the nation,' the 'necessary interpreters of the public will of the king,' the 'guardians

- For an exhaustive and scholarly treatment of the Maupeou parliaments see Flammermont, J., Le Chancelier Maupeou et les parlements (deuxième édition, Paris, 1885 ).

2 Flammermont, Remontrances, iii, 126. 


\section{Struggle Against Arbitrary Government I 9}

of the administration of the public force, and of the payment of the debts of the sovereign power'; granting force to our laws only in so far as, by a free deliberation, they have adopted and consecrated them, they raise their authority to the side of and even above our own, since by that means they reduce our legislative power to the simple faculty of proposing to them our desires, reserving to themselves the right to prevent the execution of them"; when, after listening to their remonstrances, the king had demanded the registration of his edicts, "they qualified these registrations as illegal transcriptions, and contrary to what they called the fundamental principles of the monarchy"; the parliaments had attempted to prevent the execution of the royal decrees, "and acting in our name against us they have dared to lay upon our people the law of disobedience to our known will."

These are all dangerous innovations, the preamble went on, to be destroyed in the germ. "We hold our crown from God alone; the right to make laws by which our subjects ought to be conducted and governed pertains to us alone without dependence and without division"; the laws are addressed to the courts "to be examined, discussed and executed"; if, after listening to their remonstrances, the king orders the registration of the edicts, "they should be executed without contradiction."

In the edict that follows the preamble, all these encroachments on the royal power are forbidden, in the future, under penalty of deprivation of office. This edict was registered in a lit de justice, the seventh of December, I $770 .^{1}$

1 The whole document is given in Flammermont, Le Chancelier Maupeou ct les parlements, I 16-120. 
The parliament remonstrated and refused to administer justice. The government at once acted in the most energetic manner. The members of parliament were summoned individually to resume their duties and when they refused were exiled, their offices confiscated, and they and their children declared incapable of ever holding any judicial office. It was a veritable coup d'état executed by a master hand. The parliaments of the provinces remonstrated and suffered the same fate. The judicial districts were reorganised, the new courts were filled with subservient officials, and, notwithstanding the great excitement throughout France and the abuse heaped upon the king, the ministers, and the new judges, the government stood firm and absolutism seemed to have triumphed.

The nation had lost its centre of opposition to the monarchy, but the opposition did not cease. A flood of pamphlets poured from the press; the dominant theme was opposition to arbitrary power. The leaders of the movement called themselves "Patriots" 1 and counted among their numbers the Jansenists, who now opposed a despotic monarchy with all the energy formerly displayed against a despotic papacy. Voltaire was not a member of this party. Mindful of the judicial murders of Calas and others he looked upon the coup d'état as an act of retributive justice. ${ }^{2}$

1 "Enfin des temps de trouble et d'oppression ont enfanté les Patriotes qui, remontant a la source des lois et de la constitution des gouvernements, ont démontré les obligations réciproques des subjets et des souverains et fixé les grands principes de l'administration." Bachaumont, i., Preface. Quoted by Rocquain, 298, note 3 .

2 Ibid., 298. "On assure que M. le chancelier, sentant la nécessité d'avoir dans son parti des plumes éloquentes, s'en est attaché plusieurs et qu'il fait même solliciter de loin M. de Voltaire, dont il flatte la vanité."-Mémoires secrets de Bachaumont (London, 1783 ), xix., 299. 


\section{Struggle Against Arbitrary Government 2I}

As a rule, the writers of the pamphlets, if not retained by the government, supported the parliaments and attacked the principles enunciated in the preamble to the edict of 1770 . In a pamphlet, printed in London and smuggled into France, the writer summed up the lessons of the English revolution of 1688 . "By the expulsion of a king, violator of his oaths, the great and true principles of societies were then established. The doctrine of resistance, this final resource of oppressed peoples, was settled beyond doubt by the exclusion of a family hereditarily despotic. It was decided that nations do not belong to kings. All these principles of passive obedience, of divine right, of indestructible power, this scaffolding of false notions upon which, up to that time, monarchy had supported itself, all that was overthrown." 1

While in this pamphlet it is not difficult to see how the study of English history was furnishing arguments to the opposition, a pamphlet entitled Tableau de la constitution française ${ }^{2}$ supplies a not less interesting example of the use made of French history. According to the current theory, expressed in this work, the government of France, formerly constitutional, had

1 Rocquain, L'esprit révolutionnaire avant la révolution, 299.

2 Tableau de la constitution française, ou autorité des rois de France dans les differents ages de la monarchie. Paris, I771. The pamphlet contains seventy-two pages. The tone and method of the work are made clear in the opening paragraph: "Jamais circonstances plus critiques n'ont inspiré un désir plus légitime de s'instruire et de connaître la nature de notre góuvernement; spectateur impartial, mais non insensible d'une révolution qui affecte diversement tous les coeurs français; étonné de voir le même objet envisagé sous des rapports si différents, $j$ 'ai cru que les principaux faits consignés dans nos annales, doivent nécessairement fournir assez de lumière pour porter sur cet objet important le flambeau de la vérité; j'ouvre, je parcours ces annales et c'est de l'ensemble des faits qu'elles renferment que je forme le tableau que je présente au lecteur." 
become despotic through the violation of the fundamental laws of the monarchy. The pamphlet is moderate in tone and the statements of the writer are supported by the citation of sources and of historians old and new. He treats his subject under the three heads of the "Origin of the French Constitution," the "Formation of the Laws" and the "Verification of the Laws." Having shown in the first chapter that general assemblies of the nation had once existed but no longer existed, he concluded: "It is thus that the parliament, as it exists to-day, was substituted for the ancient parliament, for the general assembly of the nation; it is thus that the nation allowed to be eclipsed the imprescriptible right that it had ever possessed of concurring in the political administration of the kingdom and in legislation, right that it derived from itself alone and that our kings did not confer upon it." In the second chapter, the writer attempts to show that, as the national assemblies had possessed the right to participate in legislation and as the parliaments had taken the place of the assemblies, the parliaments should enjoy this right to the same extent and with the same plenitude of authority that the nation would were it again assembled. In the last chapter, after having enumerated the fundamental principles of the French monarchy, he added: "From these fundamental and primitive laws there results necessarily another, not less precious to the French people, religiously observed up to our day and that it regards as the rampart of its liberty; it is that no ordinance or edict shall be published that has not been verified by the parliaments, a formality essential to impress upon it the character of law and to give it executive force." In the present struggle, it was believed with reason 


\section{Struggle Against Arbitrary Government 23}

that the parliaments represented the nation in giving assent to decrees; if the monarch deprived the parliaments of that right he should restore it to the nation, that had never renounced it and that had enjoyed it for fourteen centuries.

There can be little doubt that this pamphlet formulated the views of the majority of intelligent Frenchmen in the year $177 \mathrm{I}$. To these men, arbitrary government $V$ appeared to be supported neither by history nor by reason. The real right to control the monarch be- $\checkmark$ longed to the national assembly, but as this body no longer existed they looked upon the parliaments as its legitimate representatives. Should a national assembly ever be called, the parliaments would lose their delegated rights. ${ }^{1}$ There seemed, however, to be no immediate possibility of such an event. True, Mably had already conceived a way by which the parliaments might force the king to summon the states-general, but the parliaments were too shrewd to sacrifice their privileges.

It was at this crisis in the long struggle that Mira- $V$ beau first gave utterance to his views upon arbitrary power. His Essai sur le despotisme was simply a pamphlet produced by the coup d'etat of $\mathrm{I} 77 \mathrm{I}$. In the midst of this constant struggle between the monarch and the parliaments he had grown to manhood. As a mere boy his part in the struggle seemed forced upon him when his own father, an advocate of reform, was

1 Even a superficial reading of the contemporary writings like those of Marais, Barbier, Bachaumont, and D'Argenson will make clear that the parliaments had the support of the majority of the intelligent people of France in their struggle against an arbitrary government. The idea that there might be something better than this parliamentary opposition, namely, an assembly of the estates of France, frequently recurs in the writings of D'Argenson. 
punished for his criticism of the financial system of France by a lettre de cachet. It might be said with reason that he was born into the party of opposition to arbitrary power. Upon the success or failure of that party depended the whole future of France. It was Mirabeau's tireless agitation in this great cause that largely justified the eulogy of Camille Desmoulins: "All your life you have never ceased to proclaim your hatred against despotism, and more than any other you have helped to free us."

This was the social environment that was destined to shape the life of Mirabeau. In the struggle against an arbitrary government, he found his opportunity. But the manner in which he availed himself of it was conditioned by hereditary influences, by a defective education, by family feuds that made the name of Mirabeau a byword throughout France, and by his own extravagances, that exasperated his father and led to his imprisonment just as he was entering upon manhood. It is with these conditions that the present volume will deal, tracing the life of Mirabeau up to his twenty-fifth year, when by the laws of France his youth came to an end. It was the year I774. In this year he became an inmate of the Chateau d'If, a state's prison on a rock in the harbour of Marseilles. He had just completed his Essai sur le despotisme. 


\section{CHAPTER II}

THE ORIGIN AND RISE OF THE RIQUETI

$M$

IRABEAU came of a tempestuous race. If his ancestors were not literally "all devils "-as they have been called-many of them were "a little mad" and bore out to a considerable degree the popular opinion that the Mirabeaus were not exactly like other men. Here, if nowhere else, the theory of hereditary influences would seem to be justified, for in many an ancestor of the great orator are shadowed forth the most of the characteristics that distinguished the maddest Mirabeau of them all.

"I bear a well-known name. Five centuries ago your ancestors received my family, that the fury of factions had hunted from Italy." 1 These boastful words, addressed to the King of France by Mirabeau while a prisoner at Vincennes, refer to the supposed Florentine origin of his family. According to the tradition, the ancestors of Mirabeau, driven from Florence in the thirteenth century, during the struggles of the Guelfs and Ghibellines, took refuge in the little town of Seyne in south-eastern France. They were of noble blood and bore the name of Arrighetti, that, in

- Lettres originales de Mirabeau, écrites du donjon de Vincennes, pendant les années 1777 , I778, I 779 et 1780 (4 vols., Paris, I792), ii., 129. 
the course of time, became transformed into Riqueti. ${ }^{1}$ In the sixteenth century, the family purchased the noble estate of Mirabeau on the Durance and was thereafter known by the name of its possession. ${ }^{2}$

The origin was so attractive withal, and offered so satisfactory an explanation for the passionate and independent natures of the family, that it was readily accepted and no embarrassing questions were asked touching the evidence upon which it rested. Carlyle, more poet than historian, treated the episode in his grandiloquent style and added, "In this manner did the Arrighettis (doubtless in grim Longobardic ire) scale the Alps and become Tramontane French Riquetis." Such is the tradition, and all works treating of the life of Mirabeau-except the most recentrepeat the story with slight variations.

But what was the evidence upon which the tradition rested? It was chiefly a memoir, pretendedly the work of Mirabeau himself, and published in 1834 by his adopted son, Lucas de Montigny. ${ }^{3}$ The only

1 This is the spelling adopted by $M$. de Loménie and M. de Montigny. It is, also, the common spelling. The marquis wrote the name, almost without exception, Riquetty; his son spelled it Riquety. De Loménie, Les Mirabeau (5 vols., Paris, 1879-189r), i., r9, note.

2 The name Mirabeau was, of course, not a family name, but the name of an estate. The Riqueti were not the first to bear the name. There were, moreover, two estates with this name, and they have often been confounded by the biographers of Mirabeau, Mirabeau-les-Digne and Mirabeau-les-Durance. It was with the latter that the Riqueti were connected.

${ }^{3}$ The Mémoire is found in volume one, pages 6-189, of the work entitled Mémoires biographiques, littéraires et politiques de Mirabeau. écrites par lui-même, par son père, son oncle et son fils adoptif (8 vols.' Paris, $1834-5$ ). Before 1834 the proof of the Italian origin of the family was found in the Lettres de Vincennes and in the writings of the genealogists who had been employed by the Riqueti. Peuchet (i., 9) cites D'Hozier, Armorial de France, "cinquième supplément in folio, article Riquety." 


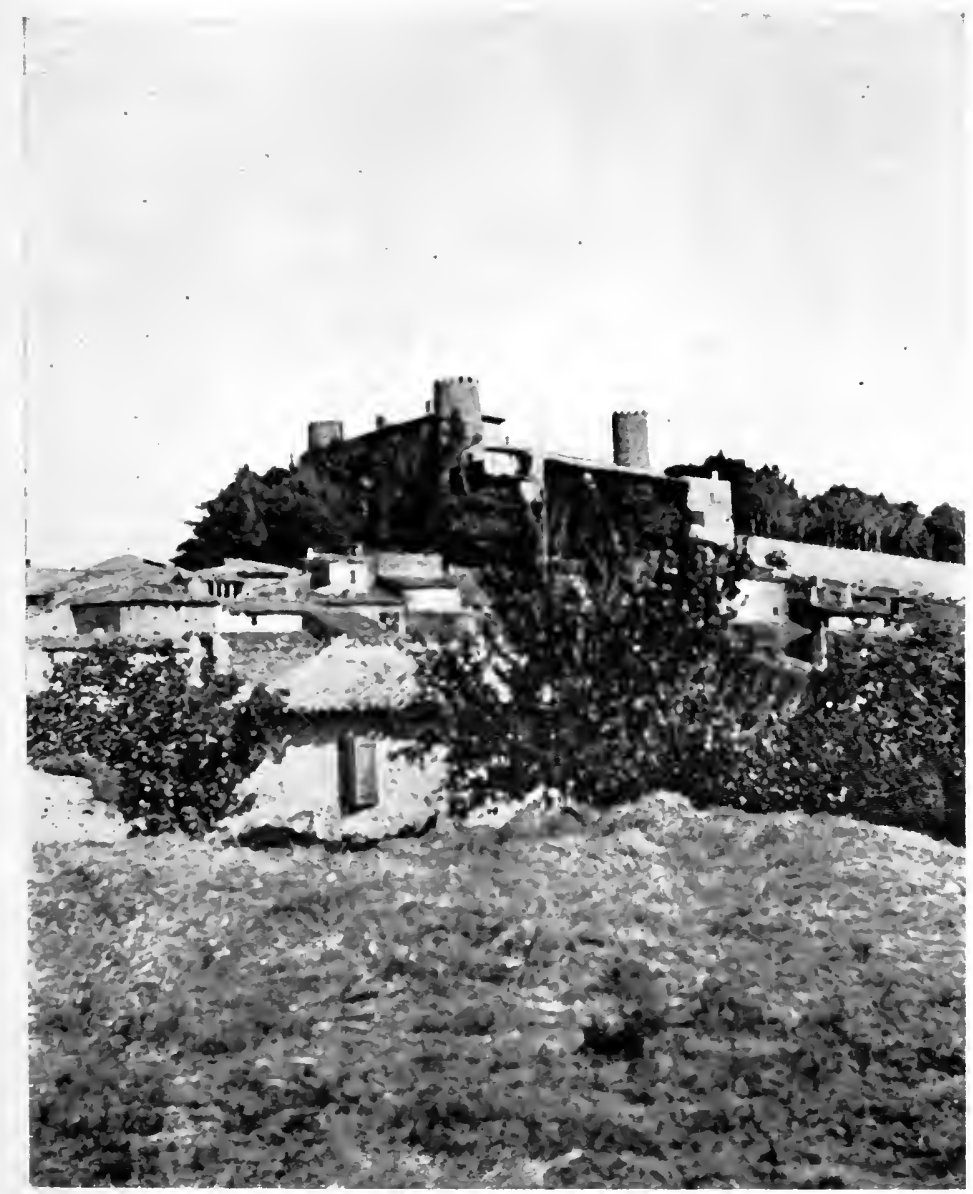

Chateau de Mirabeau

(From the west)

From a photograph by the author 


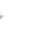




\section{The Origin and Rise of the Riqueti}

reference that it contains to the flight from Florence is found in a single paragraph and consists of a simple statement unsupported by a particle of proof. $1 \mathrm{M}$. Louis de Loménie has shown, in his exhaustive study of the origin of the Riqueti, that the memoir passing under Mirabeau's name was really the work of his father, the son having copied the manuscript when it came into his hands in $178 \mathrm{r} .^{2}$ So small was Mirabeau's own contribution that in one hundred and eighty-nine pages only two belong properly to the copyist. The changes made by Mirabeau were of such a character that his work cannot be relied upon even as a faithful copy. ${ }^{3}$

It is not for the purpose of prejudicing the reader against Mirabeau that he is presented in such an unfavourable light in these opening pages. $\mathrm{He}$ was a notorious literary buccaneer, and if, in his pillaging expeditions, he laid hands on the property of his ancestors, the historian is forced to charge him with plagiarism even before the man himself appears on the

1 "En 1267 et 1268 , et dans une de ces révolutions que produisait chaque jour la lutte de l'empire et du sacerdote, toute la famille des Arrighetti, signalée dans le parti des Ghibelins, fut chassée de Florence. L'acte de proscription indique le nom de neuf et entre autres Azzucius Arrighetti filius Gherardi, et omnes masculi descendentes ex eis. Azzucius se retira, avec son fils Pierre. en Provence, ou le père mourut en r294."-De Montigny, Mémoires de Mirabeau, i., 8.

$2 \mathrm{M}$. Louis de Loménie discovered the original manuscript, in the handwriting of the marquis, in the material loaned to him by M. de Montigny. De Loménie, Les Mirabeau, i., 2 r.

3 Extracts from the two manuscripts are given by M. de Loménie (i., $8 I-84$ ) in parallel columns for the purpose of comparison. $M$. de Loménie calls attention to the "rare sagacity" of Sainte-Beuve who, writing of the Mémoire at the time of its publication by $\mathrm{M}$. de Montigny ( 1834 ), remarked that its style "differed from that of the other works of Mirabeau, that it was more antique, more like the style of his father." 
scene. The revelation of a fresh case of plagiarism was, however, but a small part of the service rendered by $\mathrm{M}$. de Loménie to the cause of historic truth. $\mathrm{He}$ submitted to a patient and critical examination the claims of the Riqueti to an Italian origin and to a place in the haute noblesse of France extending back into the Middle Ages. ${ }^{1}$

It resulted from his investigations on the first point "that the French origin of Mirabeau is as probable as the Italian origin." The case might in all fairness be stated even more strongly, for, as M. de Loménie has shown, the evidence upon which the Florentine origin rests is practically worthless. "The Provençal Riqueti," writes M. Mouttet, " has nothing in common with the Florentine Arigheti, not even the name. They belong to this Provence that Mery called the Italy of the Gauls." 2

1 This work has been done so carefully and so exhaustively that it will never be necessary to do it over again. The two chapters devoted to this topic (vol. i., chapters i. and ii.) are models for that sort of investigation. It is unfortunate that the sources of information are not always fully indicated.

2 Mouttet, Alexandre, La galérie du Chateau de Mirabeau (Aix-en-Provence, I894), 27. On the same page M. Mouttet adds the following note: "Riqueti, comme beaucoup de noms en $i$, n'est en France que la forme latinisée du nom, telle qu' on l'écrivait autrefois sur les chartes, avant qu' elles fussent rédigées en français. Cette finale $i$ est latine et non italienne, on ne saurait trop le répéter; elle indique la filiation et pas autre chose. Littéralement $R$ iqueti veut dire fils de Riquet, abréviation d'Henriquet, dérivé d'Henri. Les Italiens, de leur cote, ont Arrighi et Arrigheti, au lieu $d$ 'Henri et d'Henriquet, mais rien n' a établi qu' il y avait parenté entre les deux familles."

"Quant l'édit de François I. (I539) prescrivit aux notaires d' écrire leur actes en français, la piupart des familles abandonnérent cette forme latine, exemple les Riquet de Caramon; tandis que quelques-unes $\mathrm{y}$ persistèrent, le plus souvent pour donner à leur nom une tournure italienne, selon le courant du jour-c'est le cas des Riqueti de Mirabeau.

"Tout nous porte à croire que c'est le point de départ de la 


\section{The Origin and Rise of the Riqueti}

The conclusions reached touching the early importance of the Riqueti in France are equally iconoclastic. It is the not uncommon story of a family that began in obscurity, but through the energy, independence, and intelligence of its members became in time wealthy and important. Having raised themselves above the masses by their efforts, they became ashamed of their original obscurity and laboured untiringly and successfully to make the beginning seem commensurable with the end.

The earliest trace of the Riqueti is found in a document bearing the date of June $26,{ }_{3} 346 .{ }^{1}$ From this document, it appears that a certain Pierre Riquet was at that time one of the three consuls or mayors of the little town of Seyne in the Basses-Alpes. "These modest municipal functions," observes M. de Loménie, "in a very small city, shared in 1346 with Pelissier and Bernard, do not give precisely the idea of a patrician of the plus haute noblesse, allied by marriage with the house of the counts of Provence."2

From Seyne, the family appears to have moved south to Digne, and from Digne, at the beginning of the sixteenth century, the Riqueti transferred their residence to Marseilles. Until the last half of the sixteenth century, this is, in reality, all that is known of the origin of the Riqueti. Here were no descendants of exiled Florentine nobles, but simply a Bas-Alpine family, that, like many another family of the same region before and since, had gravitated to Marseilles, moved by the love of trade. ${ }^{3}$ And the sons of the légende d'une extraction florentine, qui, on vient de le voir, ne repose sur aucun document authentique."

1 Loménie, i., $37 . \quad 2$ Ibid.

3 Demolins, Edmond, Les Français d'aujourd'hui (Paris, r9oo), 30. After pointing out that the poverty of the soil of the Basses- 
persons of ignoble birth holding noble estates. ${ }^{1} \mathrm{He}$ won his case, but the very fact that he was obliged to prove his nobility is evidence in itself that, at the best, it was a very obscure nobility. To have established his rank was a gain financially as well as socially and probably the thrifty "merchant of Marseilles"-as he is called in the royal acts-had the one advantage fully as much in view as the other.

During this investigation, references to the Italian origin of the family first appear. ${ }^{2}$ Little was established at the time, but the seed was planted that was to produce astonishing results in succeeding generations. It is not my intention to trace through several generations the attempts of Mirabeau's ancestors to connect their family with the Florentine Arrighetti. It is sufficient to say that the effort culminated in the time of Mirabeau's father, who caused investigations to be made at Florence. Although he found little evidence, he made good use of it, and it was not until $M$. Louis de Loménie had completed his investigations that it was known that the evidence was "such stuff as dreams are made of."

But the reputation of Jean Riqueti rests upon something more solid than a happy marriage and a successful lawsuit. Both in politics and in business, he was undoubtedly one of the most prominent citizens of Marseilles. In politics, he supported the Catholic party in the Huguenot wars and saved the city for the $\mathrm{King}$; $^{3}$ in business, he was one of a company formed to

1 Loménie, i., 35-38. The title claimed by Jean Riqueti and borne by him and by the next two generations was that of écuyer, or squire.

2 Ibid., i., 35, 43-77.

3 Montigny, Mémoires de Mirabeau, i., I4-16. 


\section{The Origin and Rise of the Riqueti}

manufacture scarlet cloth, "à la fasson de Venise." The company was organised in $157 \mathrm{I}$ and the following year was granted the monopoly in the manufacture of the particular kind of cloth for eight years. ${ }^{1}$ The business was a considerable one, the company buying its own wool in Spain, Italy, and southern France and also carrying on trade with the Levant and the Barbary states. The leading spirits in the company seem to have been two brothers, Lois and Baptiste Drera. The fact that an ancestor of the orator was a marchand de draps at Marseilles may be the foundation for the myth that Mirabeau engaged in the same business in that city in 1789 .

After Jean Riqueti's happy beginnings, the work of raising the family rank went steadily on. The era of the makers of fortunes was now practically past;

1 Archives départementales des Bouches du Rhone. Seven documents: (I) Acte notarial du XVI siècle. (2) Série B, Parlement de Provence, extrait du Registre N, II4 des lettres royaux, folio I347. (3) The same, folio I 35 r. (4) The same, folio r 352 . (5) The same, folio $\mathrm{I} 355$. (6) The same, folio $\mathrm{r} 356$. (7) Registre N, I08 des arrêts à la barre, folio ro74.

The first document (March 9, I57I) contains the articles of agreement among the members of the company; the second is the Lettres patentes of the King (Oct. I8, I 572) granting the company the monopoly in the manufacture of the cloth of Venice; the third (April 29, I574) and the fourth (Sept. 27, 1575) are Lettres patentes renewing the monopoly; the fifth is a request (undated, but probably Oct. or Nov., I 575), made by the company to the parliament of Aix, that the Lettres patentes be registered; the sixth is a note (Nov. I4, I 575) to the effect that the decree of verification has been granted; the seventh (same date) is the decree itself.

Neither Mirabeau nor his father seems to have been acquainted with these documents; at least, they do not make use of them. The Mémoires (i., I 7) refer to a "compagnie du corail qui fit des affaires advantageuses et probablement Jean Riqueti eut part à ses succès." In referring to Jean Riqueti, Mirabeau speaks of his fortune as being made in " le commerce sans monopole." (Montigny, Mémoires, i., I 9.)

vol. $\mathrm{I} \longrightarrow$ 
the era of the spenders of fortunes had come for the Riqueti. They continued to hold important offices at Marseilles or in Provence, to support the kings in their struggles against parliaments and Huguenots, to make brilliant marriages, and finally succeeded in making their younger sons chevaliers of Malta. Even at this time, their nobility was of such recent date that the secret proof was employed in the entrance to Malta, thus enabling the family to escape a searching examination of its origin. ${ }^{1}$

In 1685 , barely a century before the revolution, in recognition of services rendered and of devotion to the monarchy, the estate of Mirabeau was raised to the rank of a marquisate. At this date, the Riqueti changed the modest title of esquire for that of marquis and entered finally into the haute noblesse. Mirabeau's father was only the third of the family to bear the title. $^{2}$

Meanwhile, another means had been employed to rescue the early Riqueti from obscurity. The makers of genealogies plied their trade as industriously in the eighteenth century as they did in the nineteenth. They were not all men of spotless name who were thus employed to prove the genuineness of Riqueti nobility, but the work improved with time and the last maker of genealogies was no less a man than the well-known herald Louis d'Hozier, and the work in which the record was published his Armorial de France. ${ }^{3}$

During this second period of their family life, the Riqueti were not unimportant figures in the history of the south of France. They fought in the King's wars in Italy and in Spain; they went to court and one

1 Montigny, Mémoires de Mirabeau, i., 25-52

2 Ibid., i., 23 ; Loménie, i., 45, 53. 3 Ibid., i., 47-77. 


\section{The Origin and Rise of the Riqueti}

served in the King's guard and was a friend of the King himself. They began to live in a more lordly way, spending the fortunes made by their merchant ancestors and entailing much hardship and economy on succeeding generations. ${ }^{1}$ They were, above all other men, noted for their independence, frankness of speech, and eccentricities. One of them, a great-grandfather of Mirabeau,_. "the first and the last of the race destined for the church," remarked Mirabeau-was offered the succession to the bishopric of Digne on the sole condition that he pass three months in a seminary. He was dissipated, enamoured of an independent and fainéant existence; instead of accepting the offer, he replied coldly that if fate destined a mitre for him, it must fall perpendicularly upon his head in the streets of Marseilles. ${ }^{2}$

Of Bruno, officer of the King's service, and of François, chevalier of Malta, brothers of the man who would not be a bishop, numberless eccentric acts are recorded and of such a character that men of that day would seem to have been justified in speaking as they did of the Mirabeaus as "all devils." Even the father of the orator said of his grandfather Bruno, "He was not master of his head and appeared a brilliant lunatic, but a lunatic, nevertheless; one ought to be a little mad, but he was too mad by three-fourths." 3

1 Montigny, Mémoires de Mirabeau, i., 27, 28. The descendants of Jean Riqueti were: Honoré II., Thomas, Honoré III., JeanAntoine, Victor, and Honore-Gabriel, the orator. Thomas, the marquis wrote, "porta, très loin le luxe et le faste. Aussi laissa-t-il ses affaires dérangées, premier et infaillible effet du vent de la cour." As a result, Honore III., the successor to Thomas, was obliged to retire "avec sa famille à Mirabeau, où il vécut plusieurs années dans la plus étroite économie."

2 Montigny, Mémoires de Mirabeau, i., 37.

3 Ibid., i., 46. 
Of none of these men is enough known to enable the historian to form a clear conception of his life and character. With very few exceptions, their eccentric acts and equally eccentric sayings are recorded nowhere but in the memoir written by their descendant, the Marquis de Mirabeau. ${ }^{1}$ The paternal grandfather of Mirabeau, Jean-Antoine, is the first of the line who is known to us by something more than a date or an anecdote. Here, at last, is a man of flesh and blood. $\mathrm{He}$ was, in so many ways, a remarkable character, and indirectly exerted such an influence upon the life of Mirabeau, that he demands more than a passing notice.

$\mathrm{He}$ was born November 28, r666. He passed his youth at Mirabeau, receiving but little education, and before the age of eighteen was a musketeer in the royal army. "It is difficult," wrote the marquis, describing his father at this age, "to be more favoured by nature than was this handsome young man. He was five feet ten inches and had a perfect figure. Adroit in all exercises, he had the ability to handle himself such as no other person ever had. His noble, charming, military face expressed all the fire that devoured his soul." 2

Jean-Antoine was, certainly, "one of the rudest men of war that battled in the armies of Louis XIV." For twenty years, he fought in all the wars, bearing a charmed existence until the battle of Cassano. Here

1 Montigny, Mémoires de Mirabeau, i., 52-189; Loménie, i., 79-105. There are some very important differences between the Mémoire written by the marquis and the copy made by his son. The foot-notes supplied by M. de Montigny to the copy are, in reality, as M. de Loménie has shown, portions of the original Mémoire. Other portions of the original that were modified by Mirabeau are given in the original form by M. de Lomenie, whose work is thus needed to control the Memoires de Mirabeau.

2 Loménie, i., 86. 
he was "killed"-to use his own expression-and left upon the field. Saved by a miracle, covered with scars, with his left arm in a sling and a silver collar around his neck to hold his head erect, he returned to Provence. It was this physical wreck of a man that won the admiration of Françoise de Castellane, whom he met at Digne, the home of his ancestors, where he had gone to take the waters. The grandson of such a man might well exclaim, "Impossible! ne me dites jamais ce bête de mot."

The marriage of Jean-Antoine to the beautiful Provençale and his crippled condition did not prevent him from returning to the army, to serve four years more as brigadier in Dauphiné and in Flanders. Disgusted with the incompetency of the generals, disheartened by the death of the Duc de Vendôme, he sold his regiment and retired from the service. After the battle of Cassano, the government offered him a pension, but he asked that it be divided among six captains of his regiment who had been disabled at the same battle. As for himself, "he had served only for honour, and although he had dissipated a part of his fortune in the army, there still remained enough so that he need not become a burden to the state." $\mathrm{He}$ withdrew to Provence, and passed the rest of his life, with the exception of the last few years, at the Chateau de Mirabeau.

His career as a soldier was unique in many ways. In battle, he knew no fear, recklessly exposing himself and protecting his men. Towards his superior officers, he was respectful when he believed that they deserved respect, but otherwise brutally frank in his expression of disapproval. After a terrible engagement in which the regiment of Jean-Antoine had been nearly annihi- 
lated, he was received as a hero by the army. A brother of the minister, M. de Chamillard, was brigadier. Addressing himself to Mirabeau, he said, "I promise you that I will render a good account to my brother." The response was, "Your brother is very fortunate in having you, for without you he would be the most stupid man in the kingdom."

The civil commissioners, employed at this time as army inspectors, he thoroughly despised. On one occasion, the young captain reached his troop just after it had passed the inspector; he had been marked absent. The arguments of the major availed nothing; the captain had been marked absent and absent he must remain. Mirabeau, who had listened in silence, now asked, "So, Monsieur, I am absent?" "Yes, Monsieur." "In that case, Monsieur, this takes place in my absence," he replied and fell upon the commissioner with his riding-whip.

In the latter days of Louis XIV., frankness of speech was no aid to promotion, and this man was frank in his speech to the verge of folly. Shortly after his recovery from the terrible effects of the battle of Cassano, he was presented to the King by Vendôme, with the remark that from the entry of the French into Italy until their retirement he had never quitted his harness for a moment. "Yes, Sire," added Mirabeau's ancestor, "and if, abandoning the flag, I had come to court to bribe some. strumpet, I would have had my advancement and fewer wounds." It is needless to say that he did not receive his advancement.

By his soldiers, he was adored, "as the thunderbolt that they were sure of having at their head on every occasion." He was thoroughly devoted to their interests, obtaining whatever he wished for them because 
he asked it only for "the others" and because he never gave up. "He protected them against vexatious details and aided them in their affairs before tribunals of all kinds."

Such were the characteristics of the soldier. The qualities that made him feared and respected in the army rendered him useful in Provence. He treated the peasants on his estates as he had treated the soldiers of his regiment. Intolerant of idlers, he set himself the task of training up an industrious population. Thoroughly interested in all of their affairs, he was tireless in rendering them aid. $\mathrm{He}$ protected them against the extortions of tax-collectors and advocated their causes and the causes of the poor in the courts.

Forced to practise the most strict economy to restore the fortunes of his house, Jean-Antoine was reduced almost to poverty by the loss of a large sum in the crash that marked the collapse of Law's notorious system. His administration was so successful, however, that at the end of his life the estate was unincumbered and a surplus of two hundred thousand francs was bequeathed to his children.

Towards his children, he was as severe as towards his soldiers or his peasants. No close friendship existed between them. "I never had the honour," wrote his son, the father of Mirabeau, "of touching the hand of this respectable man, of this father essentially good, but whose dignity restrained his goodness, that always made itself felt without ever showing itself on the outside." He saw little of his father and never had connected conversations with him. "If it is true," the son added, "that initium sapientice timor Domini, he inspired us with all that was necessary to make us 
wise." And this fear was so deeply rooted that the son experienced it even when he had grown to manhood. As Jean-Antoine had lost the use of his right arm, his wife acted as his amanuensis. "I was so accustomed to be frightened on receiving his letters, " wrote the son, "that all my life, then as well as forty years afterwards, I was never able to open a letter from my mother without palpitation of the heart."

The last few years of his life were passed at Aix, in the midst of his friends and admirers. The evenings at his home were veritable lycées d'honneur, the old marquis entertaining his guests with martial tales, narrated with dignity and with an eloquence that seemed to foreshadow the remarkable genius of his grandson. During his last illness, he was unwilling to take nourishment. When it was urged upon him, he replied, "All my life, when I said no, I meant no." It was the belief of the son of Jean-Antoine, that his life was lengthened through the thoughtfulness of his wife, who guarded him against "all occasions of discontent and emotion."

She was, doubtless, one of the most beautiful as well as one of the most remarkable women of her day. ${ }^{1}$ Her courtship and marriage were by no means commonplace. To a proposition of elopement made by the impetuous suitor, she replied that "surprises are good only in war," refusing to marry without the consent of her parents. The young wife was twenty years younger than her husband, to whom she was thoroughly devoted. The foundation of her devotion was the profound respect that she felt for the scarred hero of many battles. On one occasion, a friend ventured a reference to the haughty and impetuous

1 Loménie, i., 107-126. 


\section{The Origin and Rise of the Riqueti}

character of her husband and remarked that her friends were sorry for her. "Ah, madam!" she replied, "if you only knew how happy one is to be able to respect one's husband!" Long contact with such a man was, naturally, not without effect upon her own character. She became severe, austere, a little haughty and, at times, a little rude. She expressed herself with an "energy that made the half-men of that day tremble," remarked one of her sons. At the same time, she had a good heart and was "born to love what she should love." 1 The proof of the nobleness and goodness of the mother is found in the deep and undying affection with which she inspired her sons.

The grandfather of the orator died before the birth of the grandson; the grandmother lived until the boy was twenty years of age and influenced profoundly his early life. During the last three years of her life her mind was deranged and, at times, she was violently insane. ${ }^{2}$ This ending, so pitiful and so unmerited, made a deep impression upon her sons. "It is the only event of my life," wrote the father of Mirabeau, "that has tempted me to sin against my absolute cult of resignation to providence." 3

Such was the origin and such the rise of the Riqueti. These men were "the predecessors and precursors of Mirabeau. To speak of him without speaking of them, would be a useless undertaking. To comprehend and

- Correspondance générale, iii., 32I. The chevalier to the mar. quis, Oct. I4, I 760 .

2 Gleichen, Charles-Henri, Souvenirs (Paris, x 868), I I7-II9."La nature a redemandé cet automne à ma digne mère une raison qui fut unique jusque-là. Tombée dans l'enfance, elle ne sorte plus de sa chambre."-The Marquis de Mirabeau to Rousseau, Paris, May 25, x 767. Strecheisen-Moultou, M. G., J.J. Rousseau, ses amis et ses ennemies ( 2 vols, Paris, I $86_{5}$ ), ii., 544 .

3 Loménie, i., 121. 
judge him, it is necessary to have constantly before our eyes the strange race from which he had sprung and of which he was to reproduce all the characteristic traits; the happy dynasty that, after a century of efforts, of essays, of rough models, produced at last this astonishing offspring, this sovereign of two years."1

1 Rousse, Edmond, Mirabsau (Paris, 1891), 45. 


\section{CHAPTER III}

\section{THE CHEVALIER AND THE BAILLI DE MIRABEAU}

$\mathrm{O}^{\mathrm{p}}$

$F$ the seven children of Jean-Antoine, but three survived him: Victor, Charles-Elzéar, and LouisAlexandre, better known as the marquis, the bailli, and the chevalier or the count. The first was the father of Mirabeau; the second an uncle who was a model brother and who sympathised with his nephew as the father was never able to do; the last, in many ways, a veritable prototype of Mirabeau himself.

In accordance with the old Roman practice, that persisted to a remarkable degree in the south of France, on the death of his father, Victor Riqueti became the head of the family and cared for the interests of his younger brothers. At the age of thirteen, and with very little previous education, Louis was placed in the army as a second lieutenant of infantry. Vauvenargues, a cousin of the Mirabeaus, was an officer in the same regiment and watched over the boy with all the solicitude of an elder brother. "He has, like you," wrote the young mentor, "very violent passions. I find in his disposition something of the Riqueti that is not conciliating; he has, however, a great desire to render himself esteemed and that will correct him. . . . His will is as decided as your own, and that is the only fault with which one may reproach him." 1

1 Gilbert, D. L., Euvres posthumes et auvres inédites de Vauve- 
Although, like some of his ancestors, the young count had reason to complain of the favouritism of the court, he nevertheless performed his duties manfully and showed by his conduct in many a battle that he was a worthy son of the old veteran, Jean-Antoine. At twenty-four years of age, he was a captain. By his next act, he dishonoured the name of Mirabeau and made it the laughing-stock of France. He became enamoured of Mlle. Navarre, one of the numerous mistresses of the Marechal de Saxe, and married her. His family was scandalised and disowned him; France laughed and found in the episode excellent material for the vaudeville stage and for the novel. His wife died shortly after the marriage, and Louis-Alexandre, living in destitution at Avignon, made the acquaintance of the Markgraf von Baireuth, who was passing that way, and became his grand chamberlain and privy councillor.

His career, from this time on, was brilliant enough to cause his mother and brothers to forgive all past misdeeds. Twice he was sent on an embassy to the French court, the first time by no less a man than Frederick the Great. In the dark days of 1757 , on the advice of his sister, the wife of the markgraf, the Prussian King empowered the Comte de Mirabeau to go to Versailles to purchase peace. The effort was not successful. The incident would hardly be forgotten by such a man as Frederick, and, doubtless, explains in some degree his willingness in later years to receive the nephew of Count Louis-Alexandre at Berlin.

The complete restoration of the prodigal was effected

nargues (2 vols., Paris, I 857), I01, I 23, I 30, I 39, I40, I 57, I 89, 199 , contain the references to the chevalier found in the letters addressed by Vauvenargues to the marquis. 


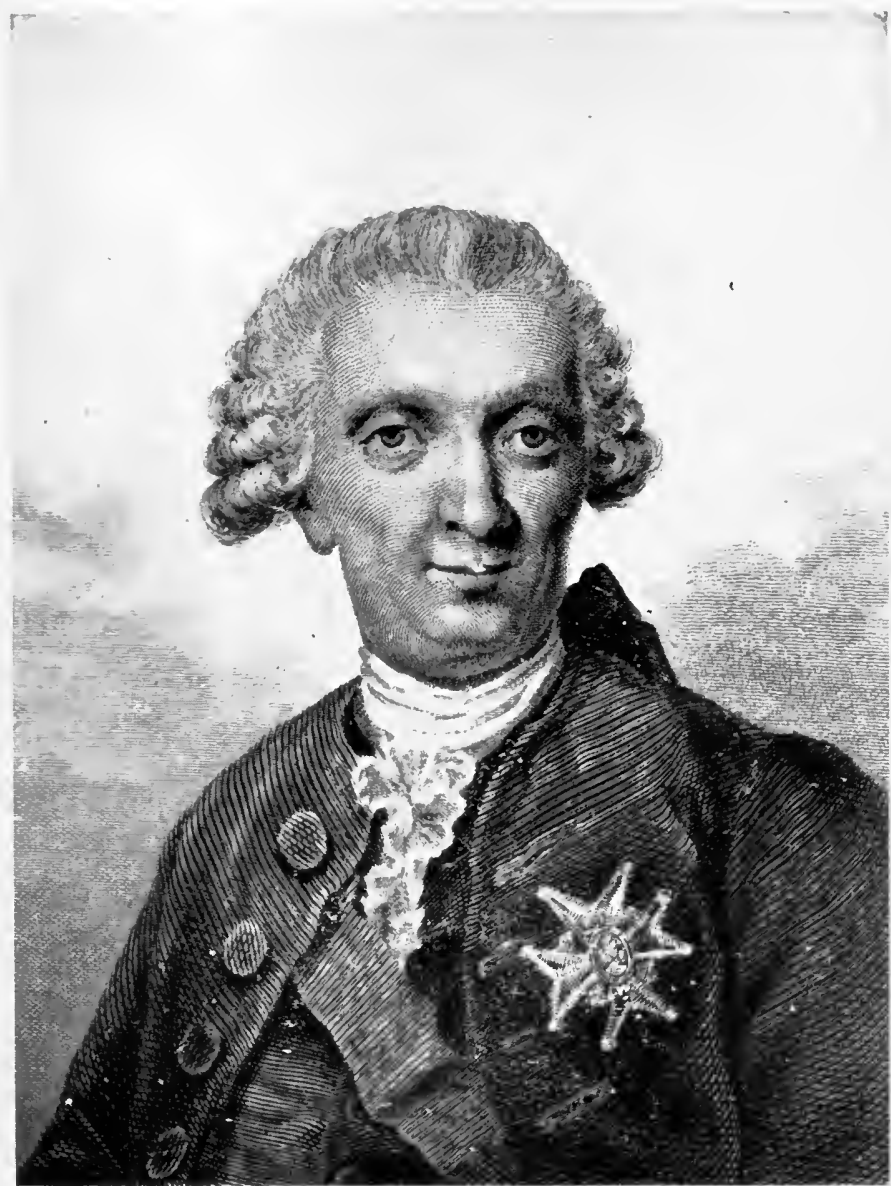

Marquis de Mirabeau

From the painting by Thérèse Boucher. (I $78 \mathrm{I}$. ) 


\section{The Chevalier and the Bailli de Mirabeau 45}

by his marriage with a pretty young German, the Gräfin von Kunsberg, and in 1760 , accompanied by his wife and with a goodly retinue, he returned to his family and was received with open arms. The next year, the count died. His young widow became a member of the household of his brother, the marquis, and remained there until her death in $1772 .{ }^{1}$

Quite a different character was the Bailli de Mirabeau. M. de Loménie has justly said of him that "he is incontestably the most beautiful moral product that issued from this impetuous and often unruly race." This man, of whom Mirabeau wrote, "He has the soul and the virtues of a hero," was the only one that inspired his nephew with "an unalterable respect." Although he did not obtain "the passing celebrity of his elder brother, the author of L'ami des hommes, nor the brilliant renown of his nephew," he does not suffer from comparison with either of these. Intellectually their equal, "he was superior to them in nobility of soul, in uprightness and in loyalty of character, in disinterestedness, and in the delicacy of a scrupulous conscience-in a word, in all the qualities that constitute an honest man." A frankness of speech characteristic of his family and a radical dislike for dissimulation and sham made a political rôle impossible for such a man in a country governed by a Louis XV.2

'Montigny, Mémoires de Mirabeau, 1., r94; Loménie, i., r 2 7-r 43.

3 The material for the life of the marquis is found in the excellent chapters of M. L. de Loménie (i., 1 45-333) and in Montigny, Mémoires de Mirabeau (i., I98-209). I have also read the manuscript correspondence between the marquis and the bailli from which MM. Montigny and Loménie obtained their information, but as $M$. de Loménie has reprinted the most important portions of the sources, it seems sufficient to refer to his work. 
Resembling his father in form, gesture, and voice, his mother in facial beauty, Mirabeau's uncle was a strikingly handsome man. In mind, as well as in face and form, he united the characteristics of his parents. The fiery temperament of the race, inherited from his father, was modified in him, more than in either of his brothers, by the lymphatic temperament of his mother.

Made a chevalier de Malte, he began his apprenticeship upon the galleys of the order before he was sixteen years of age. "For three or four years," wrote the marquis, when referring to the early life of his brother, "he did not pass eight days of the year out of prison, and as soon as he was released immediately drank again to excess. He thereupon attacked all who came in his way until he was overpowered and taken to prison." This dissolute period was, however, of short duration. At eighteen, the young man was master of himself, and never again yielded to his passion for drink.

After twenty years of service, during which he had cruised in many seas, taken part in several engagements, been severely wounded and even a prisoner of war in England, he reached the grade of captain, and, shortly thereafter, was made governor of Guadeloupe. No better choice could have been made. The chevalier -for he was not yet a bailli-was not only a man of remarkable honesty and one who approached his public duties with a deep feeling of his responsibility to society, but also a man of uncommon industry. During the long years of service, he had been preparing himself for such a place as this by patient and careful study of every branch of the service to which he belonged. He had not only observed, read, and reflected, 


\section{The Chevalier and the Bailli de Mirabeau 47}

but he had committed these reflections to paper in the form of mémoires, full of wise suggestions of reform.

A colonial governorship, however, was not an agreeable position for a man with such high notions of integrity and such an uncontrollable desire to remedy the glaring abuses of the service. In a letter to his brother, he characterised his administration and indicated the abuses against which he was forced to contend: "I have the satisfaction of hearing it said that there is general contentment with my administration and that I am given credit for my great desire to do good. The rascals, who are not few in number, tremble; the honest people rejoice; the poor know that justice will be rendered to them without regard to persons. The door of their governor is open to them, they say, at all hours and the whole colony knows that not one of my servants would dare to prevent the smallest and poorest negro from stating his case to me. They know, also, that I wish for neither presents nor property dishonestly acquired; that I have neither wife, nor mistress, nor relatives, nor friends; that I am a real Melchizedek who neither drinks, nor gambles, nor holds receptions, and if I fail to render justice it is because I was deceived."

In the midst of all these labours, his chief recreation was study and he constantly importuned his brother for books. Without ceasing, he was engaged in augmenting his knowledge, hoping that some day he might be called to a more important place. "If sight and health do not fail," he wrote, "in six years I shall be better able to manage the whole policy of the navy than anyone that has hitherto meddled with it." This boast seemed to be justified by the practical nature of his studies. He composed mémoires upon all the 
questions relative to the colonies and collected, compared, and made notes upon the different ordinances by which the colonies had been governed.

His salary was insufficient and the temptation was great to resort to illicit gains, regarded by many as the natural perquisites of the office. To nothing of this kind would the chevalier listen, even when it was suggested by his brother. He would not admit "that in his place a poor man could enrich himself honestly." Long ago, he said, he had abandoned the idea of making a fortune. "It is so much the worse for my poor nephews and nieces," he added, "but I am not sure that it is not worth more to them to be able to say that they come of a stock that prefers honour to a hundred thousand livres of income, than to be richer by property acquired by a man of their race through questionable practices."

In the new governor, the negro slaves of Guadeloupe found a protector and a friend. To his mind, slavery seemed indefensible from an economic point of view and repugnant to humanity. For the crimes committed by the blacks, he held the whites to a large degree responsible. "The slave, slave as he is, ought to be looked upon as a man and," he added, "I believe that I ought to look upon him as a brother. By way of parenthesis, not half a dozen blows of the whip have been given in my house, except to little negroes and negresses who would have received as many if they had been my children. . . . People have in this country, and frequently carry away with them, a prejudice against the negroes that is unjust. I regard that people as entirely the same as ourselves with the exception of colour. I doubt not that slavery would render us worse than them." 
Although loved by the slaves, such a man was naturally disliked by the masters and by the adventurers who came to Guadeloupe to make a fortune. Their clamours reached Versailles and called forth a friendly warning-transmitted to the chevalier by his brotherto the effect that his great severity, his zeal for reform, his failure to treat with consideration and respect the mediocrities that occupied high places, would not only injure his future but would render his ability, virtue, and probity useless to the good of the state.

The warning had no effect. Of his future, he thought little. "I owe to God and to my name," he replied, "to be the most honest man that I can. I owe to the state my sweat, my labour, my blood, and my life, provided that I am not vexed in my honour." $\mathrm{He}$ closed his Spartan confession of faith with the words: "That I make my fortune, matters little to me; that I be caressed matters little, but it matters much to me to have spoken the truth, to have performed my task, to have unveiled iniquity, to have combated vice, while in office."

Two years of residence so affected the health of the chevalier that in 1755, at his own request, he was recalled to France. When his health was restored, he would have returned to America as the governorgeneral of the Iles du Vent, but the desires of his brother and hopes of court favour induced him to remain in France.

No Mirabeau had ever known how to intrigue for favour, and the chevalier proved to be no more politic than his ancestors. He wished, however, to serve his country en grande, as he expressed it, and his whole life had been a period of preparation for such service. There were, moreover, several 
circumstances that seemed to favour him. The marquis was on the most friendly footing with the King's physician, Quesnay, and with the Abbe de Bernis, even then very influential with the royal mistress, Madame de Pompadour. But the private interview with the cause efficiente, upon which all his hopes were based, seems never to have been obtained, and although the chevalier aspired at one time to the embassy of Constantinople, at another to the ministry of marine, he was appointed to neither. The position of client of this minister or of that was intolerable to him and he wrote to his brother that "the antechambers would make a lunatic of him."

Even during these years of waiting, the chevalier did not pass all his days in idleness at court. In I756, he took part in the battle of Minorca, and in 1757 and the following year he helped defend the coast of France against the British. In I759, he was made inspectorgeneral of the coast guard, and occupied that position for two years. These were the most critical years of his life. Here ended the ambition that he had.long cherished of filling a most important office under his king and of rendering memorable services to his country; here, too, ended the one serious affection that he had ever entertained for any woman other than his mother. As the younger brother, and filled as few men of that day were with the spirit that had made the family a unit in the past, he sacrificed his own hopes, he buried his own affections, that the family, in the person of his elder brother, might prosper.

He was still only a chevalier de Malte. The final vow that bound him to the order, and made marriage impossible, had not yet been taken. By no other means, however, could he rise to a high position in the order 


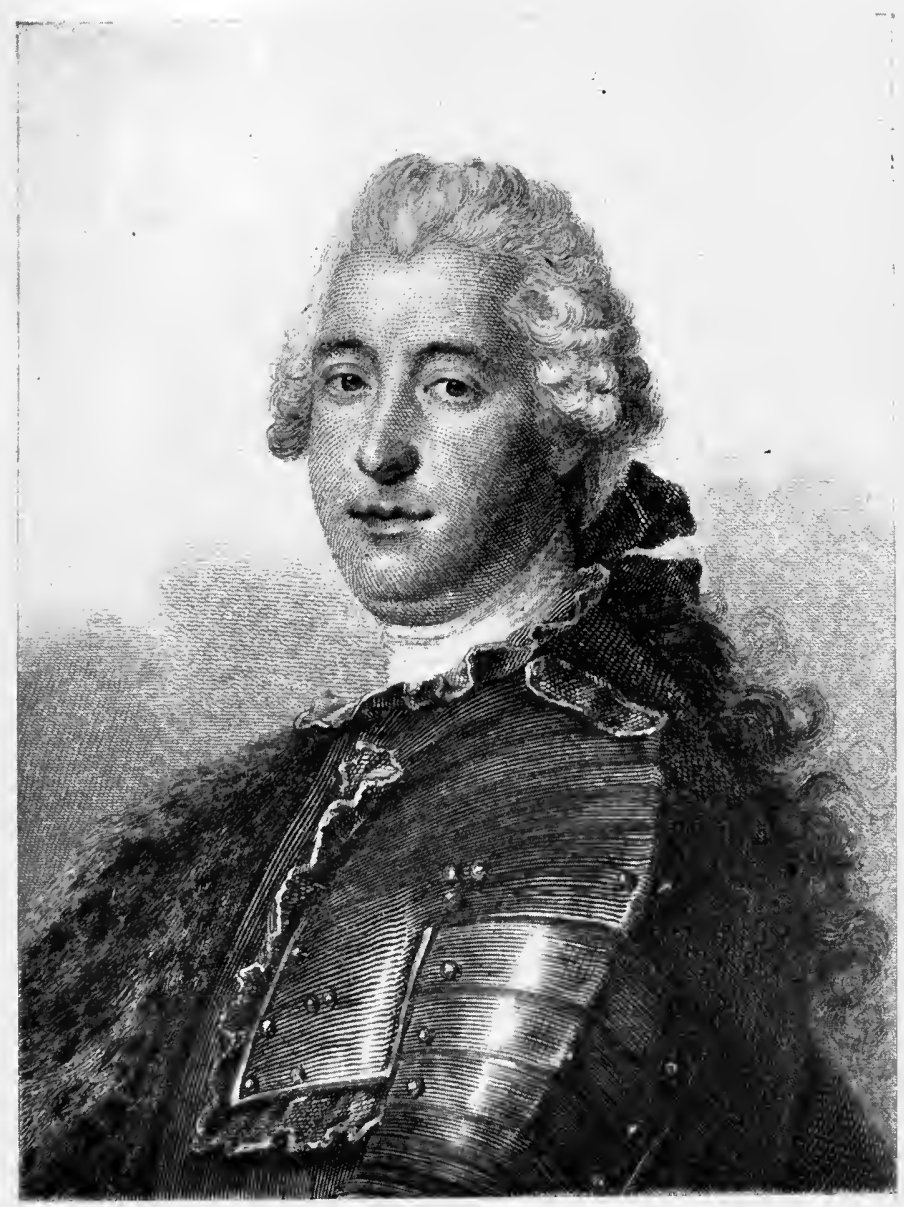

Bailli de Mirabeau

From the painting by Aved. (1 748 ) 



\section{The Chevalier and the Bailli de Mirabeau $5^{\mathrm{I}}$}

and derive financial benefits from his connection with it. In I760, he was offered the position of general of the galleys of Malta; he was forced to choose between love and duty. He had just met the woman who was "the image of his mother as she must have looked in the days of her young womanhood," for thus he described her to his brother. Had he followed his own inclinations, he doubtless would have married the dame de Caen, but the marquis, in need of the rich revenues of a commandery of the Order of Malta, made light of the matter and induced his brother to take the vows.

The affair was a speculation like many another in which the Marquis de Mirabeau had engaged. A1though one of the vows was that of poverty, the expenses of installation and entertainment for the two years amounted to I 40,000 livres. Of this the chevalier furnished but 50,000. The element of uncertainty in the speculation was great. The grand master of the order might die before conferring a commandery on the chevalier; the chevalier might die before the revenues of the commandery had repaid the sums borrowed by the marquis. The chevalier laid all these possibilities before his brother before the final step was taken, but they did not shake the confidence of the marquis in the outcome of the speculation.

The bailli served his two years as general with great distinction, but was rewarded at the expiration of his term with a commandery yielding a revenue of only I I,700 livres and the income of the first year must go to the grand master. This was indeed a poor return for an investment of r 40,000 livres, and he hesitated to accept it, but did so, at last, hoping that he might exchange it for something better. In a few months, his 
hope was realised. He received a rich commandery with a revenue of 39,000 livres "that could be easily raised to 45,000 ." The speculation proved successful, for the bailli was to outlive his brother and the revenue of the commandery was to be a saving resource to a family budget always in arrears.

A brilliant prospect now opened before the bailli. The grand master was old and he was talked of as a worthy successor. But the marquis wished his brother to return to France, that they might be near each other and that the bailli might reside upon the family estate, at the Chateau de Mirabeau, and hold the vassals in check. The bailli was urged to remain; the council of the order unwillingly granted him leave of absence, but, although he hesitated, he finally yielded to the wishes of his brother and returned to France. From this time on, his life was bound up in the life of his brother as it had never been before. How close their relations were can be realised only by one who has examined the voluminous correspondence that passed between them. The devotion of the brothers to one another was an ideal thing It ended only with death.

That the Marquis de Mirabeau was capable of holding the love of such a man throughout the trying experiences of their lives, is a fact that should be given due weight in forming a conception of the character of the father of Mirabeau. 


\section{CHAPTER IV}

\section{THE YOUTH OF THE MARQUIS DE MIRABEAU}

“ LTHOUGH Nature gave me a heart both symA pathetic and upright, she also gave me one unfettered by tenderness and easily detached.

For this I thank her."1 Such is the estimate made by the Marquis de Mirabeau of his own character. The defect here noted-for it certainly is a defect, although the marquis thanks Nature for it as for a blessing-was one of the most potent causes of misfortune to himself and to his family. It was this characteristic, more than all else, that distinguished him from the bailli: the one was not lovable, the other was. Undoubtedly tradition has dealt harshly with the father of Mirabeau, but the treatment was not wholly undeserved.

The family feud that filled the last twenty years of the marquis's life did not end with his death. He died discredited in public opinion, and ironically referred to as the "friend of men, but not of his wife nor of his children." 2 The long and scandalous lawsuit with his wife, combined with his almost endless demands made upon the government for lettres de cachet, explain the public disfavour with which he was

1 Mirabeau à Vauvenargues, I4 avril, I 740. In the correspondence of Vauvenargues edited by Gilbert (Paris, 1857).

2 Essai sur le despotisme (Troisième édition, Paris, I 792), xvii. 
regarded during his life; the tradition after his death was formed by his son and the friends of his son. Little did Mirabeau imagine, as he wrote in the donjon of Versailles letters filled with bitterness against his father, that these letters, published after his death and read throughout Europe, would prove a nemesis to his father's memory; little did he imagine as, out of the kindness of his heart, he adopted and cared for the child Lucas de Montigny, that this child grown to manhood would devote the best hours of his life to vindicating the character of his adopted father.

Until the coming of $\mathrm{M}$. Louis de Loménie, historians had drawn their materials for a portrait of the marquis from the Mémoires of M. de Montigny and from the Lettres de Vincennes. Naturally the portrait was neither attractive in itself nor was it true to life. The work of retouching this portrait was done by $M$. de Loménie in a kindly spirit, but at times the high lights of the old portrait were toned down to a degree that does not seem to be justified by the evidence.

Victor de Riqueti, the father of Mirabeau, was born in $17 \times 5$ at Perthuis, in Provence. ${ }^{1}$ Of the relations between the boy and his parents, I have spoken

1 Practically the sole source for the early life of the marquis is a brief autobiography entitled Journal de ma vie. The original manuscript is among the papers of the marquis in the Archives nationales $\left(\mathrm{M}, 78_{3}\right)$. It was published in the Revue retrospective (Nos. xii., xiii., Sept. and Oct., r834). M. L. de Loménie, who was unable to find the original in the archives, in a note (i., 365) defended the marquis against the charge, made by the editor of the Revue, of mutilating the manuscript by removing the most piquante portions. To anyone that has seen the manuscript the proof of intentional mutilation is convincing. The absence of leaves might be due to accident; the cutting out of a portion of a page can be explained in no such way. That the manuscript was mutilated is a matter of certainty; that it was mutilated by the marquis is a matter of inference and of probability. 


\section{The Youth of the Marquis de Mirabeau}

in a previous chapter. He grew up under a régime of fear and, knowing nothing from experience of the comradeship that may exist between father and son, he had no belief in it and trusted only to severe methods in dealing with his own children. Although a man of such an unbending nature would pride himself upon meting out exact justice to all, he was undoubtedly influenced in the attitude that he took toward his children by the training that he had received from his father. ${ }^{1}$

His childhood was passed in the chateau on the Durance and his early education was received at a Jesuit college either at Aix or Marseilles. ${ }^{2}$ At the age of thirteen, he was attached to the regiment of Duras, formerly commanded by his father. After serring three years, he was sent to Paris and placed in one of the so-called academies, for the purpose of perfecting him in the physical exercises useful in his profession.

He was supplied by his father with a letter to Duga, the head of the academy, "which apparently gave him full power," but the letter was never presented,

1 In a letter to the marquis (March $\mathrm{I}_{3}$, I 740 , Correspondance, I 87), Vauvenargues criticises the use of harshness and severity in education, closing with these words: "Ce que je dis de la sévérité combat l' exemple d' un père, qui soutenait ce défaut par de grandes vertus, par un esprit solide et par une éloquence mâle; je serais bien fâché d' attaquer sa mémoire; mais, comme elle me condamne, qu'elle vit dans votre cœur et $\mathrm{y}$ confond peut-être les vertus et les défauts, je crains qu' un respect si juste ne soit un préjugé contre mes sentiments."

The marquis responded (Correspondance, r98): "Votre systeme est d'arriver aux bons fins par la suplesse; le mien est d'arriver au bien, droit devant moi, ou par la violence; de fondre sur le mal décidé, de l'epouvanter et, enfin, de m' éloigner de ce qui n'a la force d'être ni l'un ni l'autre."

${ }^{2}$ Loménie, i., 157 . 
and the young man remained largely his own master. ${ }^{1}$

Well might he call these months of $I 73 \mathrm{I}$ and $173^{2}$ passed in Paris "very stormy." He was a true son of Provence, and "a shrewd and lively Provençal is soon master in the streets of Paris." Placing himself at the head of a group of young fellows, "who did not amount to much," he became the evil genius of the wealthy students. In December of his first year in Paris, after having indulged in "astonishing excesses during the four days of the Christmas holidays," he was attacked by the small-pox that claimed so many victims that year. Restored to health, he declared that he abandoned "the whole train of debauch into which vanity rather than inclination had plunged him." This statement, however, is hardly borne out by his own accounts of his later acts. "My purse, already nearly depleted, had been exhausted by this sickness and my father was deaf to demands that I did not dare repeat. He left me six months without a sou; not only had I not paid to Duga the quarter in advance, according to the custom of the academy, but I owed him one. But youth consoles itself for everything; when my shoes were worn out, I put on my boots. I had no fastening for my hair, and two feet longer than myself, ${ }^{2}$ wavy, bright chestnut in colour, it floated about my body; add to that the cross of Malta and an old surtout; it was enough to go to the parterre of the comedy that was paid for now by one of my friends, now by another, often to applaud an actress that we

1 Revue retrospective, No. xii., 366.

2 There is undoubtly an error here in the text of the Revue. I have translated the French as it stands: "Mes cheveux de deux pieds plus longs que moi." 
cut off in the midst of a tirade and permitted to leave the stage without saying a word." 1

Young Mirabeau and his comrades having taken possession of the parterre, "there was nothing that they did not do." Now the orchestra was forced to remain silent between the acts, while the young men "sang the songs of Provence and Languedoc that the Parisians love so well"; now the actors were forced to promise that Tartuffe, the play demanded by the noisy occupants of the parterre, should be the next presented, and when the promise was not kept any other play was rendered impossible until the Duchesse de Bourbon interceded in behalf of the players and effected a compromise.

"But love came then to give me a veritable occupation; I became enamoured of the little Dangeville, a young actress of great vivacity and charm on the stage. I worked myself up so over the affair that I became insane; the trouble was to make it known to her; to go to the theatre, I did not have a sou." He was ignorant, he asserts, at that time that "one may make a beginning by writing to a woman." $\mathrm{He}$ solved the problem by prowling about the house until he had attracted the attention of his lady's maid. "I talked with her with so much ardour concerning her mistress that she was astonished." The maid aroused the curiosity of her mistress and an appointment was made. "I was in the seventh heaven, but I trembled while waiting for her. She appeared." At this exciting point, the marquis thought it wise, in later years, to apply the scissors to the manuscript. When he again takes up the narrative, we learn that "the little

1 All quotations dealing with the life of the marquis up to 1736 are drawn from the Journal. 
Dangeville" accepted him as her lover, for he speaks of his great grief in leaving her in June of the next year. They parted "after many tears and protestations of fidelity." In six months she had another lover. "That cured me entirely" he added, "and I thought no more about her."

At the command of his father, he returned to the army. He had obtained a company in his father's old regiment and it was hoped that in time he might command the regiment itself. A severe attack of fever, a long period of convalescence passed in Switzerland, a return to the army and participation in the campaign of 1734 , filled the three years of absence from Paris. In December, 1735 , he was back in the city with one hundred pistoles in his purse. He was "to see only good company," he writes, "to be presented at Versailles, to ask for a regiment, to avoid all society of young people; finally, I saw clearly what was to be done, but not how to do it." Attired in a new habit of velvet, he called upon his uncle, the chamberlain of the Duc de Maine, but received no help. "Paris is not the place where one presents one's nephew," he was told. Forced to introduce himself, he preferred to frequent society of doubtful character and to delay as long as possible his visit to Versailles.

At length, in the first days of 1736 , he set out alone for court. He was so fortunate as to encounter at Versailles the lieutenant-colonel of his regiment, M. Massauve, who introduced him to Barjac, the valet of Cardinal de Fleury. Nothing was accomplished. Massauve informed Barjac that Mirabeau would give ten thousand livres for a regiment, but the valet refused the money, saying that he could do nothing for the young man. 
By the first visit to Versailles nothing was gained; the second was no more successful. After he had been introduced by his uncle to the King, the Queen, the dauphin, and the ministers, he was advised to return to Paris, but decided to remain and try his fortune in the antechambers of the cardinal. There were economic reasons, also, for remaining: "As I had no more money, I preferred to remain at Versailles, where I had but one repast, for which no pay was asked as long as I remained, and I had only to pay M. Duquesnoy, my rascally valet de chambre, my only domestic." At least five times each day, Mirabeau was present at the passing of the cardinal. On one occasion, as he waited at the foot of the staircase leading into the court, with coat buttoned up, as usual, and with both hands in his pockets, the cardinal, descending, missed his footing and fell with the whole weight of his body upon the young suitor. "A courtier would have pretended that he was crippled, at the same time saying, 'It is nothing'; as for myself, I did not have wit enough to move," and the cardinal had been conducted to his carriage " before I thought of the accident that had happened to His Eminence."

This sort of life "lasted some time"; how long, the Journal does not state, but possibly a few weeks. Upon the advice of his uncle, who gave him ten louis to pay his debts, he left Versailles and returned to Paris with four louis in his purse. The allowance from his father was not due until March; meanwhile, he led a hand-to-mouth existence: "There was no question of a carriage, for above all I did not want to owe anybody." He lived as many a young man lived in those days in Paris: "I wrote every morning; at one o'clock, I took a cup of coffee with a roll, and 
went to sup with Madame d'Andressel." His daily expense was thus the price of a cup of coffee with a roll and thirty sous for his valet. $\mathrm{He}$ enumerates "all these miserable details that they may furnish a lesson to fathers who would be too niggardly with their sons and to sons who spend more than they have."

As the time drew near when his allowance was due, he anticipated it, began to "eat a little," and kept a carriage, sharing the expense with his friend $\mathrm{Du}$ Chatelet. "My father having instructed me to sell a share of the stock that he had to pay my board, I engaged a lackey (he already had a valet), and soon after a footman, whom I clothed richly. That soon brought me to the end of my 2,000 livres." Thespring was approaching and he needed to replenish his wardrobe. He thought of leaving Paris for his regiment. Having a letter of credit for 75,000 livres on the Paris banker, to be used in paying for his regiment, if he obtained one, he called upon him and stated his intention of leaving the city. He was assured that it would be much wiser to remain, as this was precisely the time when favours were asked and granted. "I told him that I had no money," writes the marquis. " You have only to ask,' he said, 'I have enough at your service.' I thanked him, but said that I did not want my father to know that I borrowed, and that I could pay him only at the end of a year. 'Give yourself no concern,' he answered, 'you may pay when you wish and your father shall know nothing about it.' I thanked him and took three thousand five hundred livres. So I was well furnished with funds. I supplied myself with spring clothing and let myself go a little in every direction without engaging in a debauch."

At the end of May, he left Paris for Besançon to be 
present at the inspection of his regiment. Travelling in a post-chaise, with lackey, valet, and footman, he attracted much attention. At Besançon, his quarters became the meeting-place of the young officers, who presented themselves each morning, "as at my levee." In a duel with one of his fellow-officers, caused by a mere bagatelle, he wounded his adversary dangerously. The affair occurred at a time when the government was treating such matters with severity, and it was only through the protection of those high in place that he escaped punishment.

Here, in the summer of 1736 , the Journal ends. The record was made while the events were fresh in the marquis's mind and everything indicates that he told the truth. Animated by the desire "to see a true portrait" of himself, he wrote with a frankness not found in many mémoires. It was the abandon of youth that composed the Journal; it was the discretion of age that expurgated it. What the unexpurgated edition must have becn, may be inferred from the character of the portion that was not destroyed.

In May, 1737, Jean-Antoine died and Victor Riqueti became the Marquis de Mirabeau and the head of the family. His own master, with a net income of 16,000 livres a year, at twenty-one years of age, he was free to follow his bent without fear of a father's anger. It would be interesting to know what his debts were when he came into his inheritance, for before his father's death he was certainly living far beyond his allowance.

The knowledge of his life for the next four years is drawn almost exclusively from his correspondence with Vauvenargues. ${ }^{1}$ That he should have bound to

1 Gilbert, D. L., Euvres posthumes et cuvres inédites de Vauvenargues (Paris, I 857 ). 
himself, by a sincere attachment, "the noblest and most delicate moralist of the eighteenth century," is highly creditable to the heart and head of the young marquis. The correspondents were of the same age but extremely unlike in character. The one, wrote Vauvenargues, was "ardent, choleric, more agitated, more superb, more unequal than the sea, supremely avaricious of pleasures, of knowledge, and of honours"; the other-Vauvenargues-was "feeble, restless, unsociable, without taste for the ordinary interests of life, stubborn, peculiar, and anything else you please." 1 Although undoubtedly unjust to himself, the moralist drew a true portrait of his friend.

Both were in the army and ambitious to rise; but young Mirabeau possessed a good physique, a satisfactory income, and superfluous energy, while his cousin was lacking in all these things. The marquis, who was quick to discover his friend's literary ability, endeavoured to communicate to him some of his own energy and to induce him to prepare himself for some serious work that would make him famous in the world of letters. How much of what Vauvenargues really accomplished was due to Mirabeau's persistent spurring, it would be difficult to say. To the mind of the marquis it was unpardonable that one who thought and expressed himself as his friend did should not be ambitious. His insistence drew forth from Vauvenargues almost a cry of pain: "Spare me, I beg you upon my knees!"2 But the marquis was relentless, only insisting the more. If Vauvenargues "died leaving to us some imperishable proofs of a genius at once profound, animated, and attractive, we owe it, perhaps, to the

1 Vauvenargues à Mirabeau, January I6, I740. Gilbert, I66.

2 Ibid., June 30, I 739 . Gilbert, 138. 


\section{The Youth of the Marquis de Mirabeau $6_{3}$}

indefatigable excitations of his young friend who repeated incessantly: "You are unjust toward yourself, if you question your genius; work for the public; you would be culpable if you allowed the talents that nature has given you to be buried." 1

The marquis himself had even at this time literary aspirations. He had early acquired a taste for reading and a mania for writing; he called it "scribomanie." $\mathrm{He}$ had described the campaigns in which he had engaged $^{2}$ and had composed a journal of his life to the year I739. His correspondence with Vauvenargues was largely a literary exercise, and when the young moralist exclaimed, "My name and your letters will be printed together; that is the way that fortune and reputation come," 3 the marquis treated the matter more than half seriously. As early as I 739, he dreamed of the French Academy, spoke of his "reputation made by his friends," and referred with pride to the "republic of letters." 5 "I work to occupy myself," he wrote; "that amuses me, and I am acquiring a great facility in all kinds of composition." $6 \mathrm{He}$ composed a comedy, that he planned to have presented in Paris," "tragedies without love and verse."8 Few traces of these works remain.

1 Loménie, i., 389.

2 The manuscript accounts of these campaigns are found in the Archives nationales $\left(\mathrm{M}, 78_{3}\right)$. In the introduction to his Journal, the marquis refers to "les journaux de mes campagnes."

3 Vauvenargues à Mirabeau, Sept. 5, I 737. Gilbert, 9r .

4 Mirabeau à Vauvenargues, April 24, x 739. Gilbert, I 24.

Ibid.

- Mirabeau à Vauvenargues, May I6, r 739. Gilbert, I32.

- Vauvenargues à Mirabeau, May, 30 I 739; Mirabeau à Vauvenargues, June I4, I 739; Vauvenargues à Mirabeau, June 30, I 739. Gilbert, $\mathrm{r}_{35}, \mathrm{I}_{37}, \mathrm{r}_{3} 8$.

- Vauvenargues à Mirabeau, May 30 , I 739; Mirabeau à Vauvenargues, August 15, I 740. Gilbert, I35, 220. 
Although writing hurt his eyes, he boasted on one occasion, "I do not believe that anybody in the world has spoiled more paper than I have." 1 In a letter to Vauvenargues, he exhorts him to preserve his thoughts upon paper, "were it only for yourself." And he added: "The foolish things that I scrawled at seventeen give me infinite pleasure. It will be the same in six years with what I am writing now." 2

But, as interested as the marquis was in belleslettres, he was a soldier by profession, and during this period from I737 to I74I "wished to make himself known by war alone." 3 The year after his father's death he was again in Paris, hoping to obtain a regiment. It was the old experience. A friend with six years less of service, but more of a courtier, was successful; Mirabeau came away empty-handed.4 He was much chagrined, but he did not think for a moment of abandoning his calling. "Ambition devours me, but of a peculiar kind; it is not honours that I seek, nor money, nor benefits, but a name, and, finally, to be somebody; to accomplish that, a place is necessary. This kind of ambition has led me to look in many directions, and to such a degree, that in the present crisis, if $I$ had wanted a regiment in a foreign service, I knew where to get one." His relatives and friends opposed this plan and he abandoned it. 5

After a year passed at Bordeaux, where he read, wrote, disputed with Montesquieu, joined his regiment when necessary for inspection, and had a number of desperate love affairs, ${ }^{6}$ he returned to Versailles on the same old quest. His patience was becoming exhausted.

1 Mirabeau à Vauvenargues, Sept. 7, I739. Gilbert, 149.

2 Ibid., I50. 3 Ibid, April 19, I 738. Gilbert, 97. 'Ibid.

s Ibid., April 30, I 738 . Gilbert, 98. Gilbert, 103-1 54. 


\section{The Youth of the Marquis de Mirabeau 65}

A position that had been promised to him was given to a child of thirteen years; he decided to quit the service. ${ }^{1}$ To the remonstrances of the Secretary of War, he replied that he would never see Versailles again except as colonel. ${ }^{2}$ "If I enter the service again," he wrote to Vauvenargues, "it will be, in truth, without any taste for it." ${ }^{3}$ He did not at once carry out his intention, and when war broke out in 1742 , he decided to make one more campaign. After a few months with the army in Bavaria, he returned to Paris to attempt, for the last time, to buy a regiment. Failing again, he retired from the service never to return. He was convinced that his turn would never come "until favour ceased to rule at court." 4

Ambitious to make a name for himself, believing in his own merits, and finding his legitimate attempts to rise in the army rendered fruitless by the vices of the government, he naturally became a critic of the ancient régime.

But an account of the early life of the Marquis de Mirabeau would be incomplete without some reference to a serious defect in his character, "his too great passion for women." 5 Vauvenargues reproached him with it and he confessed that the reproach was well founded. He even declared in a later letter that voluptuousness was the hangman of his imagination. "I shall pay very dearly," he added, "for my follies and the derangement of my morals that has become a

' Mirabeau à Vauvenargues, January 7 and March I3, I 740. Gilbert, I6r, I70, and note page 174 .

2 Gilbert, I 74, note.

3 Mirabeau à Vauvenargues. February, I 740. Gilbert, I 74.

- Montigny, Mémoires de Mirabeau, i., 2 r 3.

5 Mirabeau à Vauvenargues, February, r 740. Gilbert, 72. vol. $1-5$ 
second nature to me."1 Not only did he pay dearly for it, but the same unbridled passion was inherited by his son and became the curse of his existence.

In his letters to Vauvenargues, the marquis writes freely of his endless affaires $d u$ cour. In the opening letter of the collection, he sends his friend a note that he has received from a discarded mistress, who is attempting, he believes, to win him back again. $\mathrm{He}$ treats her so brutally as to call forth from Vauvenargues an expression of pity for."the poor girl who loved him." 2 During the year at Bordeaux, he passed from one mistress to another, finding in each fresh affair the one great passion of his life and displaying a virtuosity in lovemaking that might well challenge comparison with that of his notorious son. ${ }^{3}$ At the close of the year I 739, he summed up his experiences retrospectively as follows: "I made my début by a veritable passion; had, thereupon, several flirtations, and ended with a love that will last, I think, all my life."4 He accompanied this last love to the French frontier and the correspondence' contains no further trace of her.

From this brief sketch of the early life of the father of Mirabeau, it is possible to disengage the salient features of his character and to form some conception of their importance for the life of his son. Marquis de Mirabeau possessed unusual talents, accompanied by a devouring ambition and a serene confidence in his own ability. It might be added that the remarkable industry that he displayed, his power of hard work and

1 Mirabeau à Vauvenargues, August I 5, I 740 . Gilbert, 220.

2 Vauvenargues à Mirabeau, August I2, I 737 . Gilbert, 89.

s Gilbert, 103-1 54 .

- Mirabeau à Vauvenargues, Oct. 6, I 739. Gilbert, I 53 . 


\section{The Youth of the Marquis de Mirabeau 67}

of productive effort, went far to justify both his ambition and his self-confidence. Uncompromising in advocating what he believed to be true, harsh even when just, he could not conceive that address and gentleness were reconcilable with honesty and force of character." He was a "man hard and rigid, a man all of one piece, full of severe maxims, intoxicated by his own virtue." 2 He boasted of his inflexibility, ${ }^{3}$ and declared that his way to accomplish anything was by going straight at it, or by violence. 4

He possessed what Vauvenargues called "the odious shortcoming of being vicious and severe at the same time."'s Passionately fond of women, he was too ready to overlook vice in his own person and to treat it with severity when encountered in others. The vicious tendencies of his son were, undoubtedly, largely hereditary; the chief explanation of the boy's defective training must 'be sought 'in' the father's character.

1 Vauvenargues à Mirabeau, March I3, I740. Gilbert, I83. Mirabeau à Vauvenargues, March 29, I 740. Gilbert, I99.

2 Vauvenargues à Mirabeau, March I3, I 740. Gilbert, I 85.

3 Mirabeau à Vauvenargues, February, x 740. Gilbert, I 74.

- Ibid., March 29, I 740. Gilbert, I98.

5 Vauvenargues à Mirabeau, March I 3, I 740. Gilbert, 185. 


\section{CHAPTER V}

\section{MATRIMONIAL AND OTHER SPECULATIONS}

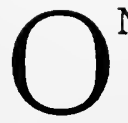

$\mathrm{N}$ the eve of his withdrawal from the army, while engaged in the last fruitless efforts to secure a regiment, the Marquis de Mirabeau had already begun the negotiations that were to culminate in his fateful marriage with Marie-Geneviève de Vassan, the mother of the orator. The marriage itself, and the tragic results that were the effect of it, were the natural fruits of the family organisation and of the conception of marriage under the ancient régime. The former, even as late as the eighteenth century, was a remarkable example of the survival of a Roman institution.

Nowhere in France did Roman life leave a more lasting impress than in Provence, the first Roman possession beyond the Alps. Here, even on the eve of the revolution, the father was the head of the family, exercising at times a power closely approaching that of life and death. Upon him rested the responsibility of preserving the honour of the family and of passing on the family possessions, not only intact, but augmented by his own acquisitions. He administered a trust and was under obligations to give an account of his administration to his posterity. In the Roman world, these records were transmitted from father to son. They were known as Tabulae, or Codex expensi et depensi. The Roman family had also its archives 


\section{Matrimonial and Other Speculations 69}

in which were deposited the mémoires (commentarii) of its ancestors, the genealogical tables (stemmata), and the funeral eulogies (laudationes mortuorum). The Livre de raison of Provence was the natural continuation of the Tabulae. It was the "book of the house," in which the head of the family was accustomed to record the essential facts of his life and of his domestic administration. ${ }^{1}$ It is from such a record, commenced by the marquis in 1747 , that we draw out information concerning the next period of his life. " "I am going," he announces in the opening sentence, "to give an account year by year of my administration and of all that has been done since the beginning of my reign, either by my mother, by myself, or by my agents." It is a veritable Livre de raison. In keeping it, the marquis was perpetuating an ancient and excellent custom of his native province. It was natural for him to write such a book, for he was thoroughly imbued with the spirit that had given rise to the custom. He was an ardent defender of the old family organisation, proud of his ancestors, jealous of the good name of his family, and ambitious to make of this provincial house a house of national reputation. As the head of the family, he never lost sight of the fact that his deeds would be judged by his posterity, and he was ever eager to justify himself. In his old age, he

1 A full treatment of this interesting subject of the Livre de raison and of the family life recorded in these books will be found in Charles de Ribbe, Les familles et la société en France avant la revolution. (Quatrième édition, 2 vols., Tours, I 879.)

${ }^{2}$ I have drawn the material for this chapter almost wholly from the work of M. Louis de Lomenie, volume I., chapters xvii. bis and xviii., and volume ii., chapter xxvi. bis. Besides the source already referred to, $M$. de Loménie employed in the composition of these two chapters a volume written by the marquis entitled, Mon état, tant d̀ charge qu'a décharge, en l'année I 779. 
affirmed that at twenty he had already begun to talk and write for those who were to succeed him and that three fifths of his manuscripts were only accounts of his administration, of his views, of his acts, as before their tribunal.

In such a system and to such a man, marriage was last of all a love affair. Love did not necessarily have anything to do with it. First of all stood the perpetuation of the family name and the enhancement of the reputation of the family. Marriage was, therefore, a good deal of a speculation, and for the Marquis de Mirabeau, this greatest of all speculations was to prove a lamentable failure.

In May, $\mathrm{I} 73^{8}$, the marquis wrote to Vauvenargues that he was about to marry Mlle. de Nesle, a younger sister of Mme. de Mailly, the "sultane favourite." She had great expectations, was the only one of the sisters that Mme. de Mailly cared for, and she would go to live in the provinces. In two weeks, the engagement was broken; Mlle. de Nesle did not wish to live in the provinces and the marquis was not yet enamoured of Paris. He endeavoured to put a good face upon the matter, but, although it was no love affair, he was evidently chagrined. ${ }^{1}$ The next two years were passed at Bordeaux, but nothing permanent resulted from the series of infatuations that have already been mentioned. He still asserted that he did not love Paris, ${ }^{2}$ although three months later he had bought a house in the rue Bergère and was "ruining himself to furnish it." 3 But the city quickly cast its spell

1 Mirabeau à Vauvenargues, May 20 and June 6, 1738. Gilbert, 99, 100.

2 Ibid., Oct. 6, I 739 . Gilbert, I 53.

3 Ibid., Dec. 23, I 739. Gilbert, I 56. 
about him, and before many weeks had passed he was lost to Provence. He assured Vauvenargues that the man of "philosophical ideas needs but few things." These few things were "some friends, a gay lodging, and facility in fulfilling all his desires." As such an ideal state was found only in Paris, it was in Paris that the marquis would reside in the future. The summer, of course, would be passed in the country and a country house had been purcheasd at Bignon, twenty leagues from Paris. Provence was to see little of him. ${ }^{1}$ He had undertaken the construction of a canal at Mirabeau, but, after uselessly expending 4800 livres, he was obliged to confess that the whole scheme was only a coup d'épée dans l'eau. The house in Paris, that had cost him 30,000 livres, was only a shell, while the property at Bignon, for which he had paid I I2,000 livres, was in such a dilapidated condition that all the revenue was consumed by repairs. Thus, before his marriage, the marquis had reduced his income by hasty, unprofitable investments. It seemed incumbent upon him to seek a wife with a large dowry.

While in Paris, he had made the acquaintance of a M. de Vassan, ${ }^{2}$ who had a marriageable daughter. He had never seen the young lady, but in 1743 , as he was about to start for Provence and was desirous of

1 Mirabeau à Vauvenargues, March I3, I 740. Gilbert, I 8I.

$2 \mathrm{M}$. de Vassan was the son of a président à la chambre des comptes of Paris. He signed himself, "Messire Charles de Vassan, chevalier, seigneur de la Tournelle, etc., etc., colonel d'infanterie." In I 7 9 he was named brigadier. Madame de Vassan was Anne-Thérèse de Ferrières, only daughter of Charles-Joseph de Ferrières, Marquis de Saulveboeuf. "Cette famille de Saulveboeuf, assez notable en Périgord, avait acquis par mariage, en 1626 , la seigneurie de Pierre-Buffière, près de Limoges, qualifiée première baronnie du Limousin, comme ayant été jadis l'apanage du cadet des vicomtes de Limoges." Loménie, i., 422. 
getting married before leaving Paris, "the idea came by chance," to himself and his friend M. de SaintGeorges, ${ }^{1}$ to begin negotiations for the hand of Mlle. de Vassan. M. Daoust, the notary of the marquis, accompanied by $\mathrm{M}$. de Saint-Georges, waited upon $\mathrm{M}$. de Vassan and made the proposition. In the conversation that followed, it transpired that in spite of the fact that M. and Mme. de Vassan possessed property yielding a revenue of 30,000 livres, property that at their deaths would go to the daughter, they would give her as dowry only 4000 livres annually, the revenue of an estate situated in Périgord. To the advisers of the marquis, such a dowry, for an only daughter whose parents were still quite young, did not seem "presentable." The young man, however, was not to be reasoned with. To be sure he had known the father of his future bride for five years and realised " his unfitness for anything good," but he believed that the mother, living with her daughter in Limousin, holding her property in severalty, was-judged by report-a "marvel of capacity." "It is so rare," he remarked, "to find a girl with the wealth of Paris possessing at the same time the education of the provinces, that I looked upon it as a piece of good fortune." $\mathrm{He}$ settled the question with his friends by the following reasoning: "One of two thingseither the character of these women will be agreeable to me, in which case I could live with them without compelling them to change their mode of life, and save money myself, or if it is not agreeable to me,

1 The marquis had made the acquaintance of Saint-Georges several years before in Paris and although Saint-Georges, who seems to have been a most estimable man, was a man with a family and considerably older than the marquis, the two became fast friends. 
they are suited to each other and I could leave them there [in Limousin] with their 4000 livres and I could live as a bachelor."

It was not a love affair, it was simply a business proposition, and yet the marquis acted like an ardent lover. He declared in a large-hearted way that it showed bad taste to haggle over a girl and that the four thousand livres ought to be accepted without further discussion. " $M$. de Saint-Georges, after having said that that was not his opinion, took charge of the affair. M. de Vassan, moreover, negotiated with an air of frankness that quite captivated M. de SaintGeorges, delivering to us all the letters that he received from his wife, and as she had had much experience in writing, I found these letters very interesting." It was only after his marriage that the marquis learned that the lady had sent two series of letters, one intended to be read by him and by his friend and the other for her husband. In the first, she was "very reasonable"; in the second, "she showed herself in her true colours."

The intervention of Mme. de Vassan caused continual difficulties. She insisted upon reserving for herself the right to dispose of a large part of her property as she pleased, even to the detriment of her only daughter. "In vain the notary and the friend of the young marquis urged him not to go further, charging him with Quixotism; he accepted all with a constantly increasing enthusiasm." He talked, he said, to Daoust, "with the Provençale vivacity, that always appears unnatural to the Parisians. And to tell the truth, among the Provençales themselves, I am not one of the slowest." In vain Saint-Georges protested that marriage contracts were not made in such a sentimental way; the marquis insisted and abandoned all further 
details of the agreement to his friend and $M$. de Vassan.

The conclusion of the affair must be given in his own words:

The contract was signed by M. de Vassan and myself the eleventh of April. He departed at once for Limousin, and I followed the next day. Hardly had I arrived in the country, so new to me then, when I had opportunity to note that the visor of the mind of my mother-in-law was not quite straight. ${ }^{1}$ of the formula of ratification that I had brought with me from Paris, she made complaints that I did not understand and did not wish to understand. I told her to arrange it to suit herself, and when I saw that she was content, I was also. I signed without looking, the nineteenth, and was married the twenty-first of April, I743.

And what was the character of the woman that the Marquis de Mirabeau had married with such "unparalleled thoughtlessness," this woman who was to become the mother of the great orator?. She was seventeen years of age and probably homely. M. de Lomenie, in describing a pastel that pictured the mother of Mirabeau as she appeared in her youth, remarks that the face is "not precisely ugly; it displays, it is true, in the eyes and in the mouth, an expression of sensual effrontery that appears somewhat marked, but,

1"Il déclare plus loin, que son mariage ne se serait pas fait $s$ ' il a vait connu l' esprit bifurque de Madame de Vassan, 'qui fut,' dit-il, 'à Saint-Sulpice lors de la naissance de sa dernière fille, des qu' elle fut relevée, pour voir si far hasard on n' avait pas fait baptiser son enfant sous un autre nom.' Plus loin encore, après avoir parlé des serpenteaux que peut faire 1' imagination de sa bellemère, il ajoute: 'Bonne femme au fond, mais la plus tracassière, tracessée, et tracassante femme de l'univers; elle a le malheur d'a voir l'esprit si gauche que rien n'y entre comme dans un autre.'" Loménie, i., 427 , note. 


\section{Matrimonial and Other Speculations}

taken in its ensemble, it is neither irregular nor disagreeable." 1 Some years later, the bailli declared to his brother that at the time of his marriage it was the general opinion that "he had espoused one of the most ridiculous creatures in the world." This description contained, doubtless, a large amount of truth, but just how much, it is impossible to say. Unfortunately, the evidence upon which we are obliged to depend is neither thoroughly reliable nor strictly contemporary. It consists, for the most part, of letters of the marquis and the bailli written more than thirty years after the marriage, at a time when the marquis, separated from his wife, was engaged in a scandalous lawsuit with her. A letter written by the marquis in 1776 contains a portrait of his wife that is probably not without some resemblance to the original. ${ }^{2}$

Possibly much in this description of her as she appeared after marriage was due to the "pestilential and impudent education"- to use the expression of the marquis-that she had received, but even more

1 Loménie, ii., 443. Correspondance générale, viii., $3^{\mathrm{I}} 3$. The bailli to the"Marquis de Mirabeau, Oct. I 3, I 778 : "Depuis la création du monde, on ne vit pas une femme de l' espèce de celle que Dieu te donna."

2 In a letter to Sophie de Monnier, written at Vincennes, Mirabeau characterises his mother as follows: "C'était Ninon Lenclos qui disait qu' elle remerciait Dieu tous les soirs de son esprit, et qu'elle le priait tous les matins de la preserver des erreurs de son cœur. Je dis erreur, pour que le mot effarouche moins ma pauvre mère; mais qu'est-ce que Ninon entendait par les sottises de son caur? Les faux pas multipliés où l'entrainaient sa complexion et son tempérament. Elle-même n'approuvait sûrement point ses légèretés, ou plutôt ses prostitutions. Jamais on ne fut plus aimable en amitié et plus rnéprisable en a mour. Ma pauvre mère a d'autres inconvénients encore à redouter de sa constitution presque aussi fougueuse qu'à vingt ans, c'est l'emportement où elle l'entraine. l'inégalité, les indiscrétions et les imprudences que cette inégalité nécessite."-Lettres originales de Mirabean (Paris, I 792), i., r 29. 
was clearly to be attributed to temperament. She was lacking in delicacy and gave such publicity to everything connected with her married life that "the chaste would have inferred that nature had refused her all natural shame." Desirous of reading, she could not open a serious book without going to sleep over it. She began pieces of needlework without number, soiled them all, but never completed anything unless absolutely obliged to do so by the needs of the household. When she did work, she sat upon her foot with her leg bent under her, her face close to the article she was making, the bed cover thrown over her, regardless of conventionalities, or the flight of time, or of the other demands that might be made upon her. Eating at irregular hours and indulging her love of dainties, she either had no appetite at table or she ate voraciously. As a rule, she took her seat at the table with her arms crossed or behind her back and with an absent look upon her face. She never concerned herself with her guests, neither serving them nor offering them anything. If she happened to be in good humour and talkative, "as she naturally possessed wit and humour," when her chance came and the tap was once turned, she was no longer mistress of herself and the paroxysm of laughter and talk resembled an attack of hysterics." After dinner, if she did not play cards, she fell asleep in her chair. For a man with the education, refinement, and temperament of the Marquis de Mirabeau, life with such a woman must have been before it ended what he himself described as "twenty years of nephritic colic."

Giving an account of this marriage to his descendants, the marquis argued that, everything considered, he had done an unusually good thing, "at least for 
our house, and that was all that I desired." Although the dowry of his wife was hardly sufficient to meet her personal expenses, and her character was such that he could never think of a diplomatic career, yet the "single quality that she possessed of only daughter and future heiress ... was sufficient to compensate for all the drawbacks of a marriage that brought him no present ease and that threatened to become a burden to him as soon as he should have children." In his imagination, he could see the domains in Limousin, Périgord, and Poitou united to those in Provence and the Riqueti of Mirabeau becoming a family of national importance. To realise this dream, patience was necessary, and above all the fortune must not be consumed in advance. Such conditions could be found only in a well-regulated household where husband and wife worked harmoniously in the interests of the family. For this reason the character of the woman whom he was about to marry was not the matter of indifference that the young marquis seemed to think it. "He was to learn that if it is sometimes dangerous to marry a woman for the fortune that she has, it is often still more dangerous to marry her for the fortune that she will have."

After a few days passed at the chateau of Aigueperse, the scene of his marriage, the marquis set out for Provence accompanied by the whole Vassan family, the company numbering in all, "both man and beast, thirtytwo mouths." En route, he stopped at Saulveboeuf to view the estate from which his wife's revenue was to be drawn. "The chateau," wrote the marquis, "was a beautiful collection of cut stone, but it was uninhabitable; there were windows in some places, but there was no glass. It was planked from top to 
bottom, but daylight entered between the planks." This domain that was to furnish a revenue of four thousand francs was in such a condition that nothing could be drawn from it and a considerable outlay would be necessary before it could be rented.

Meanwhile in Provence, at the chateau de Mirabeau, the mother of the marquis prepared to receive "the cloud of people." She not only stocked the larder in good earnest, but she called in workmen and changed the whole interior arrangement of the house. It was an extravagance that the marquise would hardly have committed had she known that, in the future, neither she nor her son would make a home at Mirabeau. The company remained three months, and the marquis complained bitterly of all the money that these people, who cared nothing for him, had cost him. "The house finally cleaned"-to use the language of the young husband in speaking of the departure of his new relatives-he sat down to make an estimate of his financial condition. He discovered that he had a net income of 5894 livres, or with the 2000 livres allowed him by his mother, in round numbers 8,000 livres a year. Not a magnificent sum for a man with a family. He might well have "rubbed his eyes more than once," at the results of his calculations. $\mathrm{He}$ decided to leave Mirabeau. Renting everything that he could to increase his income, selling part of his furniture and taking the rest with him, he installed himself with his mother and wife at Saulveboeuf.

At the end of two years of residence, he had improved the property to such an extent that he was able to rent it for 3200 livres. He had cut wood upon the estate to the value of 20,500 livres. M. and Mme. de Vassan were so enraged at this act "that one would 
think," remarked the marquis, "that I had stolen the money from them." They even began a suit against him, but did not press it to a conclusion.

In 7746 , "accompanied by his mother, his wife, his children, and domestics, the marquis moved once more to settle himself definitely at Paris and Bignon." His affairs here needed attention. The house at Paris, in the rue Bergère, that had cost him in ten yearsincluding the purchase money-100,000 livres, could be rented for but 2300 livres. He sold it for 85,000 livres and bought a house in the rue Saints-Pères, "smaller, but habitable." He then turned his attention to Bignon. Surrounding himself with an army of workmen, "he rebuilt the chateau, changed the course of the river that surrounded it, transformed the pastures into grass-lands, planted trees, dug ditches, and all at great expense." He confessed that he spoiled mariy things that he undertook, having neither talent nor experience that fitted him for much that he was obliged to do.

Learning nothing from experience, lured on by the hope of forming a great estate, he purchased in $175^{2}$ the duchy of Roquelaure, paying for it 450,000 livres. He borrowed the money at five per cent. This was something of a plunge for a man whose income did not exceed fifteen thousand livres. He bought the property without seeing it. It is true that his mother advised him not to "buy the cat in the bag," but the Duc de Rohan, evidently knowing his man, would not listen to delay and the marquis recklessly concluded the bargain. On visiting his estates, he learned that he had paid too much for them by one hundred thousand livres. After nine years of ownership, during which he laboured to improve his ducal property, the 
marquis disposed of it in $176 \mathrm{I}$ at a loss of fifty thousand francs. His sole satisfaction was found in playing the great lord, in signing himself seigneur $d u$ duché de Roquelaure, and in hearing himself prayed for by the cure of the parish.

That a speculator of the marquis's reckless temperament should seek to increase his resources by operating a mine was not at all unnatural, and one hardly experiences a feeling of surprise in learning that only two years after the Roquelaure episode he began to exploit, at his own expense, an abandoned lead mine located upon the property of Mme. de Vassan in Limousin. Finding the undertaking too burdensome for his unaided purse, he formed a stock company, his man-of-affairs, Garçon, signing the certificates of stock and acting as secretary and treasurer, as the marquis's social position prohibited him from having any official connection with the company. The stock was taken by his friends, and the names of many grands seigneurs figure on the list of purchasers. The demands upon the stockholders for funds were frequent; the returns from the mine were slow in coming in. The solicitations of the stockholders made the marquis unhappy. "They are impatient," he wrote, "because he had invited them to visit the works; they said that M. de Mirabeau loved to work for posterity, but as for themselves, they preferred present enjoyment." In 1768 , he wrote that "Garçon hides behind the door when he sees a stockholder coming." Just what the outcome of this speculation was is not known. We learn from the marquis that in 1776 he had invested 50,000 livres in the mine and that it "promises great things."

The only successful investment that he made during 


\section{Matrimonial and Other Speculations 8I}

all these years was when he supplied the bailli with money that enabled him to hold the generalship of the order at Malta and afterwards to secure the revenue of a large commandery.

Something still remains to be added to make clear the financial condition of the marquis in I779. M. de Vassan had died in $175^{6}$ and a portion of the property for which the marquis had waited so long fell into his hands; the larger portion still remained in the possession of Mme. de Vassan. In I 760 , with the consent of his wife, he disposed of Saulveboeuf for 60,000 livres, a sum that was quickly consumed by the demands of his creditors. When, in 1763 , his second daughter was married with a dowry of 80,000 livres, he was obliged to borrow the money. After 1762 , the marquis no longer lived with his wife, but granted her an allowance equal in value to more than half the income of the property inherited from her father. Eight years later, Mme. de Vassan died and his hopes seemed about to be realised; all the property was at last to be united in his hands. At this moment, his wife began the notorious suit against him that was to end in the loss of the entire inheritance for which he had sacrificed so much and had waited so long. That he fought it bitterly is matter of little wonder.

In r779, the marquis made a statement of his financial condition. He had an income of 80,500 livres from his estates, without counting the annuity assigned to his wife. He owed 678,740 livres and the annuity, interest, and other obligations consumed 5I,648 livres, leaving 29,000 for all other expenses. This remnant of revenue represented just the sum claimed by his wife as the annual income from the property that had belonged to her parents.

vor. $x-6$ 
The marquis boasted that he paid his debts; he did so only by creating new ones. He sums up himself the situation in a letter written in 1764 to the Comtesse de Rochefort: "My most continual and poignant care is to obtain money for all the things for which I have need of it, and which, upon my soul, was never for myself; and the farther I go and drag out my labourious existence, the more this care augments and the farther the fruits of it recoil." $\mathrm{He}$ even added that when he calmly considered his desperate financial situation, he was sometimes almost suffocated by the difficulty of living.

I have treated at some length the unfortunate matrimonial and other speculations of the Marquis de Mirabeau, not because of their intrinsic interest, but of the important part they played in the life of his son. From his birth to his death, Mirabeau was the victim of his father's well-meant but ill-judged speculations. 


\section{CHAPTER VI}

\section{L'AMI DES HOMMES}

I the opening chapter, I attempted to show that the eighteenth century in French history was characterised by an almost uninterrupted struggle against arbitrary power in the church and in the state. The struggle against arbitrary power in the church dominated the first half of the century; that against arbitrary power in the state, the last half. Both the Marquis de Mirabeau and his famous son were participants in the agitation of the latter half of the century, although the father, taking part in the discussion in its earlier stages, was naturally more conservative than the son, who became a leader in the crisis of the movement. Both were opponents of arbitrary power and both were reformers. Historians have not sufficiently emphasised these two facts, while the brilliant career of the son has too often prevented them from seeing clearly the importance of the part played by the father.

During a short period of his life, the Marquis de Mirabeau was a famous man. But the disrepute into which the Physiocrats fell, the notorious lawsuit with his wife, and the unnatural harshness that he displayed toward his son robbed him of public favour and condemned him to an undeserved oblivion. In recent years, successful attempts have been made to 
restore him to his proper place among the publicists of the eighteenth century. 1 Although his lifelong labours produced no very tangible or permanent results, it is undoubtedly true that he contributed to the revolution by influencing the mind of his son and the minds of many others who took part in the greatest movement of modern times. That it may be clear to what extent the attitude of Mirabeau toward the abuse of arbitrary power was due-either directly or indirectly - to the teachings of his father, it is necessary to describe somewhat in detail the work of the Marquis de Mirabeau as a publicist and as a reformer.

The first ventures of the marquis as a critic of society were of a very practical kind. His social position, his experiences as a speculator, and his inquisitive spirit brought him into contact with numberless administrative, financial, and economic abuses. With the welfare of society he was hardly less concerned than with that of his own family. He looked at society, however,-especially at the beginning of his career as a publicist-from the point of view of a provincial nobleman, but a nobleman whose feudal mind had been invaded by democratic ideas. ${ }^{2}$ The

1 Lavergne, Léonce de, Les économistes français $d u$ dixhuitieme siecle (Paris, I870), I12-167. The principal work of the marquis, L'ami des hommes, was published in 1883 in the collection of the Economistes et publicistes contemporains. Ripert. Henri, Le Marquis de Mirabeau (Paris, rgor). Brocard, Lucien, Les doctrines economiques et sociales du Marquis de Mirabeau dans l'Ami des hommes (Paris, 1902). Ripert deals with all the writings of the marquis, tracing the complete history of his life as a publicist, devoting but four chapters to the Ami des hommes. Brocard limits his volume to the consideration of the Ami des hommes, making a most exhaustive study of this work.

2 The expression " $L$ 'invasion des idées démocratiques dans un 


\section{L' Ami des Hommes}

contents of an unpublished manuscript, written in 1747 and bearing the title Testament politique, throw a curious light upon the hopes of the men of his class in the middle of the eighteenth century. ${ }^{1}$ The document was addressed to his posterity and was not inaptly named a "political" testament. Ambitious to lay the foundations of a wealthy and powerful family, he was led to point out to his successors that four generations, acting audaciously and prudently, in accordance with fixed principles, "would go very much farther than they dared flatter themselves at the beginning." He referred to what the Guises had accomplished in three generations, in less than fifty years, by always acting in the same spirit and following a definite plan.

"Reared by his father in the hatred of the encroachments, ever increasing since the time of Richelieu, of the royal authority upon that of the seigneurs, he liked to persuade himself that the revolution prepared by the reign of Louis XV. would turn to the profit of

esprit feodal" was applied to the marquis by Tocqueville. See Loménie, ii., 2.

1 A full treatment of the Testament politique and of the conditions. that called it into being will be found in Lomenie, ii., chapters xix. and $\mathrm{xx}$. The table of contents of the Testament will give some idea of the scope of this curious document: "Façon de se conduire relativement à la cour.-Façon de se conduire avec les préposés de la cour.-Dans quel sens et pour quels objets il faut se servir de la cour contre elle-même.-Façon de se conduire relativement aux justices supérieures où ressortissent les vôtres.-Façon de se maintenir.-Sur la façon de s'allier.-Etat et maintien de la maison domestique.-Habitation et dépense de la maison.-Façon de placer les enfants. Etiquette de la maison.-Façon de conduire les affaires.-Affaires de crédit et d'argent.-Gouvernement des terres.-Conduite avec les gens d'église.-Relations et correspondances.-Nécessité d'un testament politique dans un maison.De la permanence chez soi." 
the aristocracy and bring about a sort of return to a perfected feudal régime." He did not hesitate to "admit the hypothesis of a dismemberment of the French monarchy," adding that it was "neither to be feared nor to be hoped for," but, at the same time, he urged those who were to come after him to insure the perpetuity of their house by founding an establishment "independent of the ensemble that to-day constitutes the body of the state."

But this nobleman, who would increase his own authority at the expense of the authority of the King, had a lofty conception of the manner in which he should employ it. The administration of justice, he asserted, should be good and prompt, the officers of justice as honest and skilful as could be found, and always under the supervision of the seigneur. The lord should be a veritable father to his vassals, assisting the needy, helping them to become self-supporting, and promoting industry and trade. That he was already convinced of the value of a dense population is indicated by the statement that "one of the greatest means of vivification" of one's property "is population," and he exhorted his descendants "to attract inhabitants from all sides," adding, "Whatever expense you thus incur will be rendered to you with usury." He enforced his instructions with the advice to "care for the orphans" and "give work to the poor; it is for that alone that you are in the world, to do good with all your power."

Seeing in the intendant the representative in the provinces of the power that was destroying the authority of the aristocracy, he "declared to his successors that the first duty of a seigneur is to carry on a noiseless and concealed warfare against the appointees of the court." 
The first publication of the marquis, printed anonymously in $175^{\circ}$, was a treatise upon L'utilité des états provinciaux. It did not necessarily represent an advance beyond the views contained in the Testament politique. ${ }^{1}$ He was a vigorous opponent of the encroachments of the monarchy upon provincial liberties, and the revival and extension of the estates was generally considered by the nobility one of the most effective means of decentralisation. The aristocrat still betrayed himself in the denial of the equality of all the King's subjects, in the assertion that in a wellorganised monarchy class distinctions, based largely upon birth, must exist, and in the claim that the control of the police and the administration of justice in the provinces should be left to the notables. ${ }^{2}$ The pamphlet as a whole dealt with the matter of local selfgovernment. The ideas that it contained might, with proper limitations, be called democratic.

In truth [observes M. de Loménie], it is still an institution of the past that attracts the attention of the marquis, but it is a living institution; although much enfeebled by the encroachments of the absolute monarchy, it maintained itself, nevertheless; so that in assuming, in $\mathbf{7} 750$, the rôle of defender of what we would call to-day local autonomy, then represented by the provincial estates, very much decried by the centralisers of the time, the father of Mirabeau anticipated by twenty-five years the plans of Turgot, by twenty-eight years the attempts of Necker, and by thirty-

1 "Ein grosser Fortschritt seiner politischen Ideen tritt uns drei Jahre später in der kleinen, aber höchst inhaltsreichen, Denkschrift über die Provinzialstände entgegen." Stern, A., Das Leben Mirabeaus (Berlin, I889), i., 22. The ideas contained in the first published work of the marquis do not seem to me irreconcilable with those contained in the Testament politique.

2 Stern, i., 22. 
seven years the movement of ideas that was to impose upon the monarchy the edict of 1787 , establishing everywhere, but too late and too brusquely, provincial assemblies, which were in their turn to give birth to our general councils. ${ }^{1}$

In the middle of the eighteenth century, three fourths of the provinces of France had lost the ad- . ministrative autonomy they once possessed. The four large provinces of Languedoc, Bretagne, Bourgogne, Provence, and some of the small provinces of the north and south still retained some degree of administrative liberty. Before the marquis undertook in $175^{\circ}$ to defend the provincial estates against the attacks made upon them by the advocates of a centralised administration, Montesquieu, in his Esprit des lois ( 1748 ), had referred briefly to one of the arguments made against the assemblies. It had been charged that the province with estates paid less toward the support of the government than the provinces without estates. He maintained they paid more and that they found compensation in the right they enjoyed of taxing themselves. ${ }^{2}$ This single paragraph in a brief chapter could not have attracted much attention at the time, and it is hardly probable that it inspired

1 Lomenie, ii., 104. The account of the pamphlet on the provincial estates I have drawn chiefly from Loménie (ii., Io3-r33). Stern (i, 22-24) contains some extracts not given by Loménie.

2 "Dans de certaines monarchies en Europe, on voit des provinces qui par la nature de leur gouvernement politique sont dans un meilleur état que les autres. On s'imagine toujours qu' elles ne payent pas assez, parceque par un effet de la bonté de leur gouvernement elles pourraient payer davantage; et il vient toujours dans l'esprit de leur ôter ce gouvernement même qui produit ce bien qui se communique, qui se répand au loin, et dont il vaudrait bien mieux jouir." Montesquieu, De l'esprit des lois (Derniére édition. A Amsterdam, I 749), livre xiii., chap. xii. Quoted by Loménie, ii., 108. 
the Marquis de Mirabeau to write his work. The subject was a matter of common discussion. When the marquis's book appeared, D'Argenson wrote in his Journal, after attributing it to Montesquieu: "It is only the beginning of books of this kind that are going to appear and which it is dangerous to allow to circulate, causing subjects to desire the things that are refused them and of the advantages of which they are deprived with the grossest injustice." 1

The attacks upon the administration of the pays d'etats and what he characterised as "the absolute ignorance that exists concerning our municipal laws and our usages," led the marquis to write a book, that, by destroying these prejudices would, he hoped, open the way for other treatises, more comprehensive in character and better supplied with details than his own book was.

The question of taxation being the crucial one in the discussion of the utility of the estates, the marquis grappled with it at once. Comparing the pays d'etats with the pays d'election-as the provinces without estates were called-he showed that in the former provinces the taxes were assessed upon a real valuation determined by impartial commissioners elected by the estates; that the taxpayers were permitted to protest before another commission, elected to revise the tax roll; and, finally, that the taxes were collected by a treasurer chosen and paid by the community itself; in the latter provinces, the valuation was arbitrarily fixed by the intendant or his agents, the tax roll was revised by those who made it, and the

- D'Argenson, Mémoires et Journal inédit (5 vols., Paris, I 857), iii., 339, 340, under the date July I 5, I $75^{\circ}$. Quoted by Loménie, ii., 109. 
collection of taxes was forced upon some member of the community, selected by the intendant or his agent, and held responsible for the sum to be paid by the parish. He proved, furthermore, taking Provence as an example, that the provinces with estates paid more taxes in proportion to their wealth and paid the taxes more willingly than did the provinces without estates.

After examining the organisation of the estates in the four larger provinces, the marquis reached the conclusion that the form of the estates of Languedoc was the best. Two of the characteristic features of this assembly were double representation for the third estate and the vote by head instead of by order. These two questions 'were to stir France to the depths in 1789 , and it is interesting to note that the marquis took the same attitude toward them in $175^{\circ}$ that his son was to take in 1789 . He believed that the third estate should have a representation equal to that of the other two orders, because it bore the larger part of the burden of taxation; he opposed the vote by order on the ground that it deprived the third estate of the legitimate consequences of the double representation.

The attitude of the marquis toward public affairs is finely illustrated by a passage in which he insists upon the importance of "accustoming the principal men of a province to act as citizens, not to disdain the least details that might be useful to their country; to acquaint themselves with civil and municipal laws; to learn to deal with men, to convert them to their opinion; to know how to yield when it may be necessary; finally to render themselves fit for affairs." It was his credo as a citizen; it was to be the credo of his son.

Such was the content of the first publication of the 
Marquis de Mirabeau. While it did not especially attract the attention of the public, it was noted by men like D'Argenson and called forth inquiries concerning the author from the librarian of Maria Theresa and from the dauphin.

In 1757 , appeared the work that was to make the marquis famous. It bore the somewhat eccentric title L'ami des hommes ou traité de la population. ${ }^{1}$ It expressed the growing consciousness of social solidarity and the malaise that produced criticism and reform, both so characteristic of the eighteenth century. No longer confining himself to the consideration of a single institution, the marquis embraced in his survey the whole organisation of society, international as well as national. Frankly describing the ills from which the country was suffering, he presented a project of reform based upon a philosophy of society that regarded "the feudal system, renewed and adapted to the needs of the society of his time, as a natural transition from the economic régime of the Middle Ages to the modern régime."

The marquis had not devoted long years of labour to the preparation of the Ami des hommes. If we may believe him, the actual writing of the book occupied but a few months. ${ }^{2}$ He acknowledged that it showed

- L'ami des hommes ou traité de la population par le Marquis de Mirabeau, avec une préface et un notice biographique par M. Rouxel (Paris, I883). Although the first edition bears the date 1756, there are weighty reasons for believing that it was antedated and that it did not appear until I 757. See Loménie, ii., I37, 138; Rouxel, i., ii.; Brocard, 46, 47; Ripert, I21-125, the fullest treatment.

2 Referring to the statement of Montesquieu that he had devoted twenty years to his great work, the marquis observed, "II s'en faut bien que je n'aie employé six mois à parcourir tout le terrain que j' embrasse."-L'ami des hommes, 574. In a letter written in 
signs of haste, but added that each one must work in his own fashion and that even if he were promised many advantages that he did not hope for from his book, he could not be induced to retrace his steps in order to give to it "a more decent form and greater continuity." $\mathrm{He}$ felt certain that he would fail in such an undertaking and grow weary of it, "a state of mind not at all favourable to the writing of a work of vivacity and sentiment." Moreover, he was inclined to believe that, careless as it was in form, his book was more likely to be read than a methodical treatise, and it was readers that he wanted. All that could be hoped for from works of this kind, good or bad, was "to accustom men to occupy themselves with the public welfare, and to awaken, by some rays of truth, the natural ideas that are possessed by many privileged geniuses upon these serious and useful matters." 1 He avoided wearisome details, he indulged in repeated interesting digressions, he appealed to the feelings of his readers and to the goodness and justice of the King. It is certainly a work of "sentiment," even if it be not one of "vivacity."

The opening words of the preface, "I undertake to treat the most useful and the most interesting of all objects here below for humanity, population," give the keynote to the whole work. It is not a scientific treatise, it is a plan for the reform of society. The

October, 1760,'referring to the Theorie de l'impôt that was about to appear, he wrote, "Il est fini, chose qu'on ne pourrait croire, si l'on savait le peu de temps que j'y ai mis."-Oncken, A., Der altere Mirabeau und die okonomische Gesellschaft in Bern (Bern, 1886), 65. If we may believe the marquis, he not only wrote his works in an astonishingly short time, but he published them before they had been properly polished, sacrificing his amour propre to the good of the public. It is somewhat amusing to note that the son later employs the same methods but lays more emphasis upon them.

'L'ami des hommes, 574, 575 . 
motive for writing the book is found in a letter addressed to the Comtesse de Rochefort in r76r: "I love the people, I love men; I know how much more amiable they would be if they were happier, I have discovered the simple means of rendering them so." 1 Not only does he write under the pseudonym L'ami des hommes, but at different times he refers to himself as "the friend of the human race," 2 as "the author who treats of the interests of humanity," 3 and as one "full of sentiments of zeal and love for his fellows." He looked upon himself as the apostle of sociability, of human brotherhood, of closer friendly relations among all peoples. ${ }^{5}$

While his end was reformatory and his book had more of the tone of a treatise on morals than would be considered legitimate in a modern scientific work on economics, it was, nevertheless, a contribution to economic thought. The Marquis de Mirabeau was the first French writer "who had embraced economic questions in so complete a manner."6

Men, he believed, would be happier if they were better fed. "The nourishment of man can be drawn only from the earth, which produces little or nothing useful to us without the work of man. Population and agriculture are thus intimately and necessarily connected and form together the principal object of first utility from which all others spring." He defined wealth as consisting of nourishment, commodities, and the conveniences of life. "The earth produces it and the work of man gives it form. ... Whatever the man

1 Loménie, L., La Comtesse de Rochefort et ses amis (Paris, 1879), I10. 2 L'ami des hommes, $490 . \quad 3$ Ibid., $55 \mathrm{I}$.

4Ibid., 573. 5 Ibid., 3 I6, 40 I, 409, 4 I0, 434.

- Rouxel in L'ami des hommes, viii. 
is worth, so much is the land worth, runs a sensible proverb. If the man is worthless, the land is also. . . . God alone has known how to produce men from the earth; at all times and in all places where men were to be had, land was to be had, or the product of land, which amounts to the same thing. It follows from this that the first of benefits is to have men, the second to have land. The multiplication of men is called Population. The augmentation of the product of the earth is called Agriculture." 1

If population is the first of social goods one naturally asks, "What are the means of securing this sort of wealth?" On the other hand, "What is the true cause of depopulation?" The marquis replied that it is the "decadence of agriculture on the one hand, luxury and the too great consumption by a small number of inhabitants, drying up at the root the germ of new citizens." 2 He then states his thesis, "that the measure of subsistence is the measure of population." $\mathrm{He}$ adds that the multiplication of the species could not depend upon fecundity, otherwise "there would be a hundred times as many wolves as sheep in the world." It is an axiom, he asserts, that "men multiply like rats in a granary, if they have the means of subsistence." 3

But if it is true that the increase of population depends on the augmentation of the means of subsistence, it is equally true that an increase of population ought to cause an augmentation of subsistence as a result of the increased supply of labour. "Sterility shows itself nowhere except where inen are lacking. Agriculture, or the application of the labour of man to the earth, is not only the most admirable of all the arts, the most necessary in a primitive state of society:
- L'ami des hommes, 3,4 , 10.
2 Ibid., I 3 .
s Ibid., $13,18$. 
it is even in the most complicated form of society the most profitable and the most remunerative."1

The increase of the returns from agriculture, making possible the support of a larger population that in its turn would produce wealth, was the problem that the marquis studied from every conceivable point of view. Among the social and economic evils that were sapping the foundations of society by checking the development of agriculture, he counted the outgrown methods of farming, the lack of good roads and canals, the absenteeism of the noble landlords who had abandoned the provinces for Versailles, the movement of population toward the cities, the growth of large landed estates, oppressive taxation, the existence of tariff barriers between provinces and between states, preventing the free exchange of the products of the farm, the mercantile theory of wealth, the existing attitude toward the colonies of Europe, the abuses attendant upon the employment of slave labour in the colonies, the disastrous economic and social effects of war and, most important of all, the frightful growth of luxury. An enumeration of the topics treated in L'Ami des hommes should make clear that the marquis was fully as much a forerunner of the modern sociologist as of the economists. ${ }^{2}$

His descriptions of these evils, as they appeared to him, are valuable contributions to the knowledge of society under the ancient regime. For each evil, he suggests a remedy. For, unlike his contemporary Montesquieu, the Marquis de Mirabeau was not simply a student of social phenomena. The appreciation of this fact is fundamentally important in estimating the influence of the marquis upon his son. They were

1 L'ami des hommes, 29, 35 .

2 Brocard, 36. 
both critics of the old society and they were both earnest advocates of reform.

Among the reforms advocated by the marquis, some were practical and were destined to form part of a reorganised France; others were incapable of realisation under the existing government, possibly under any government. The nobles, he believed, should be sent back to their estates to give to them the personal attention they needed; to perform the duties that alone justified the personal privileges that they enjoyed; to increase by the expenditure of their income the prosperity of the provinces that had been impoverished to contribute to the luxury of Versailles and Paris. By the decentralisation of institutions, by the distribution of these institutions among the provinces, by the increase in the number of parliaments, by the forced residence of officials in provincial cities, the marquis believed that life in the provinces could be made once more respectable and attractive. Agriculture would receive a new lease of life, the returns from the soil would be greater, and population would increase. The solution of the problem of taxation was not to be found in the abolition of the privileges of the nobility and clergy, but in an improved assessment and collection of the taxes. These were to be the functions of the provincial estates. The marquis was well acquainted with the sufferings of the peasantry, but he did not see, or at least not at this time, that the only relief for the sufferers was to be found in a taxation based upon the ability to pay and levied without regard to class or privilege. ${ }^{1}$

" "Dans L'ami des hommes, il est visible que Mirabeau n'a pas encore changé d'avis, mais le silence qu'il garde sur cette question [equality in taxation] à laquelle il fait seulement de brèves allusions, 
The corvée, he believed, should be abolished and the building of roads and canals entrusted largely to the provincial estates, the expenses of the undertakings being met by increased taxation. All obstacles, in the form of tariff barriers, that interfered with the free circulation of grain either between the provinces or between France and foreign countries, should be removed. He advocated reciprocity between states and would even employ the most vigorous measures to force the neighbours of France to adopt this policy. $\mathrm{He}$ attacked the so-called mercantile theory of wealth, maintaining that money was the representative of wealth and not wealth itself. The state he believed should cease to interfere with industrial life and the individual should be free to follow his own bent. Denying the statement that the main object of international trade was to draw as large a quantity of the precious metals as possible into the country and that one country could gain only what another lost, he declared that both parties gained by the exchange, that commerce between states should be free, and that "humanity could prosper only by a general union." 1

The colonies, as the outlet for an excess of population, should be treated with a consideration that they had not yet enjoyed. Acquainted through the experiences of the bailli with the evils of the existing colonial system, he condemned it as iniquitous. Instead of exploiting the colonies and making the domination of the mother country unbearable, the interests of the colonies should be considered, "the yoke should be

montre assez que son embarras s'est accru, peut-être sous l'influence de son frère le bailli, qui admettait depuis longtemps le principe de l'égalité devant l'impôt." Brocard, 383 .

1 L'ami des hommes, 7 I, I92, 358, 363, 4 I 7, 424, 442-453, 493, 494. vor. $1-7$

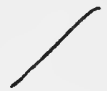


rendered so light that it would be sought as a protection and not feared as an oppression." Slavery he looked upon both as an economic and moral evil, but did not advocate the immediate abolition of it. $\mathrm{He}$ would bring about gradual suppression of it by making clear to the planters the superiority of free over slave labour. ${ }^{1}$

Toward luxury, his attitude was thoroughly modern. He was the only writer of his time who had a satisfactory theory of luxury. ${ }^{2}$ He refused to embrace in the forbidden category enjoyments that, although not indispensable to life, seemed to him legitimate on account of their utility for the progress of individuals and the government of society, and added that the intentions and social position of the consumers were as important as the nature of the thing consumed in determining whether or not it was a luxury. "If in place of being a manifestation of social power it became the sign of wealth, it constituted luxury properly speaking." Luxury he looked upon as the greatest of social evils. It injured society by reducing population and demoralised the individuals who indulged in it. Luxury could exist only where the rich man failed to realise that he was responsible to society for the use that he made of his fortune. The possessor of great estates who believes that he has the right to convert to his own arbitrary pleasures revenues of which in reality he is only the administrator is as much of a tyrant and monster as the king who dissipates the revenues of his kingdom and believes that everything was made for himself. "The richest man upon earth," wrote the marquis, "is only the administrator of a much larger portion of goods, but equally bound with the poorest to

1 L'ami des hommes, 514-555.

2 Brocard, 3 II. 


\section{L'Ami des Hommes}

administer them with fidelity and disinterestedness. The responsibility of man toward society grows" he asserted, "with his wealth, but he has for himself legitimately only what is necessary to his estate and nothing for his whims." 1

But how could the growth of luxury and its attendant evils, leading to social decadence, be checked? Not by sumptuary laws that touch only the surface of things; the reform must go deeper and deal with the morality that lies at the foundation of society. By honouring virtue and talent independent of wealth the marquis hoped to combat luxury. ${ }^{2}$

The morals of a people he regarded as "the living picture of the state of their society," and as having "infinitely more influence in society than the laws." Where a high moral standard exists, "the simplest laws are sufficient, and are even rarely appealed to." The morals that constitute the basis of a people's prosperity consist, according to the marquis, of religion, patriotism, and civic virtues. These things are matters of the first concern to a government that is seeking to agument the population of the state. The government could, however, accomplish little if it attempted to improve the morals of the people by restraint; it must work chiefly by example, especially by the example of the monarch. The real source of morality is religion. It teaches respect and submission to the government, love for one's fellows and attention to one's duties. He denied that a society of atheists could subsist. "A prince, indifferent in matters of religion, lays beneath his throne a mine that some day will leave it a heap of ruins." Denouncing in incisive language the writings of his day that were hostile to

\footnotetext{
1 L'ami des hommes, 275-3 I5.
}

2 Ibid., 328. 
religion, he declared that of all the shortcomings of the police the most condemnable was the neglect to "purge writings of all traces of irreligion." He believed that an indiscriminate liberty in the matter of writings is "the first of the crimes of lese-humanite," for "of what use," he asked, "to the public and to each individual in particular may be the display of the transitory ideas of each of them in matters of religion?" After asserting that what had been called "religious troubles were only wars of ambition and authority," he added: "Princes, then, ought to be and are infinitely more odious to the spirit of independence than religion; and, in fact, I defy anyone to show me a single book where direct attacks are made upon it [religion] that does not bear at the same time the imprint of this spirit of discussion of the right of sovereigns. Some, free philosophers, trace the beginning of this right to a respective contract between the prince and his subjects, the least transgression of which dissolves the clause and the contract." The acceptance of such a principle would, the marquis asserted, produce the very opposite effect from that hoped for by the philosophers; it would free the strong and crush the weak. Princes would make use of it to divide the people and play the tyrant. "Tyrants," he went on, "have pronounced these terrible and execrable words to posterity: You revolt, we will conquer you. These scourges of humanity were of the same sect as our philosophers. They would ignore the fact that there is a co-eternal contract between authority and dependence, a contract established by the creator with the creature, which consists in protection and security, on the part of authority, in obedience and services on the part of the dependent and, above all, in respective 
love on both sides." Some of "the dogmas of the spirit of liberty" were "so revolting" that the advocates of them "were not ashamed, in cold blood, to advise the use of the sword and courage against fictitious tyrants."

"Which, then, of these two opinions," he asked, "that of the philosophers or that which regards as duty the respective attachment between the prince and his subjects, is the more proper to give birth to and to cause to germinate in the heart that love of country" which is the second of the virtues constituting the morality of a people? The marquis described love of country as being "only a superstitious mixture of religion, of respect, of esteem and of attachment for the different orders of the republic, of tenderness for one's neighbours and fellow-citizens, of pride confounded in the glory of the country. . . May not all France be the country of a Frenchman and shall we not know how to love our country?" He affirmed, in spite of Montesquieu, that "love of country may exist in a monarchy, since it has been in vigour among us." Replying to the objection that the French loved their King rather than their country, he answered that they looked upon the King and the royal family as the representatives of the country. Love of country he defined again and more concisely, as "zeal for the welfare of the public"; the virtues that flow from it, he claimed, were still alive in his generation. He did not deny that there were signs of decay due to false standards, to the distribution of favours, to the remuneration of noble and honourable deeds by gold; and observed that if this standard prevailed there would be no more heroes, not even citizens, and the nation would become "a vile mass of mercenaries and usurers." 
The civil virtues he considered not less important than religion and love of country. Without them "all is lost." "The love of our neighbours" the marquis called "one of the first duties of society. . . . From that is developed friendship and fraternity among citizens." Our first duties, he pointed out, "are toward God, our second toward our country, then toward our neighbours, our-fellow citizens, finally toward the whole of humanity, for we are all brothers." $\mathrm{He}$ discovered signs of decay in the civic virtues. also and suggested methods that might be employed to counteract this movement. ${ }^{1}$

I have dwelt at length upon the attitude of the marquis towards morals and reform, because his views are largely those of the conservative critics of his day, because the whole book is impregnated with such sentiments, indicating a realisation of the meaning of society that goes far to explain the discussions of the contrat social and the projects of reform that filled the next forty years.

"Of war," wrote the marquis in the closing chapter of his book," "a populator ought to speak only in its relation to peace, and peace, although a gift of heaven, like all other gifts bears fruit only through our care." Soldiers he declared were no longer useful except as dogs chained in the lower court, to be released only in the last extremity. A lasting peace could be obtained not through the boasted balance of power, but by the establishment of friendly relations with other states. "A sovereign who, having rendered his people numerous, active, well organised, and happy, should thereupon treat strangers as their brothers, should open to them his ports, his highways, should communi-

' L'ami des hommes, 229-274.

2 Ibid., 555-572. 


\section{L' Ami des Hommes}

cate to them his industry, should aid them in every way to become what his subjects had become-a prince, I say, who should always act in accordance with the plan that I have traced, would find in the disposition of opinion in his favour an ever present defender, a very strong prejudice against those who were desirous of attacking him to the point of forcing him to interrupt so worthy a work by the measures of an indispensable war."

In concluding his work, the marquis appealed to "great and small, urging them to love their fellows, declaring that self-love is the sole cause of all excesses." To the King, he exclaimed: "We are all brothers by origin and destiny. . . . You have become our father by a worthy use of your functions." 1

It would not have been difficult to anticipate that a work animated by such a spirit would create a sensation and meet with astonishing success. It passed through many editions and the returns to the publishers amounted to 86,000 livres. The Marquis de Mirabeau became the man $d$ la mode. The French translation of Thomson's Seasons that appeared in 1760 was dedicated to the "Ami des hommes." The term appeared upon the signs of the Paris shops. The marquis described in picturesque language the infatuation of which he became the object: "The Parisian enthusiasm, that gives the tone to all others, attacked me with a fury to be found only here and in other enormous cities of idlers; they form a crowd, ask for copies of my portrait that appeared in the salon this year, place it in the hall of the provincial estates that have naturalised me, pay twelve sous for a chair when I go to mass, ask from me in marriage my daughters that

' $L$ ' ami des hommes, 574, 575. 
are still children, consultations, dinners, women and what not." It was said that the author "wrote like Montaigne and thought like Montesquieu" and Mercier placed him by the side of Montesquieu, J. J. Rousseau, and Buffon "in the number of great men who would be honoured as the benefactors of humanity." 1 These expressions are clearly inexact and exaggerated, but they serve to show the impression that the book made. The dauphin, the father of Louis XVI., called the Ami des hommes the breviary of honest people and boasted that he knew it by heart. He wished to make the writer assistant governor of his children, but the marquis would be governor or nothing. One of his letters to the bailli indicates that the marquis believed that there was some thought of making a minister of him.

One of the most interested readers of the book was the physician of Madame de Pompadour, Doctor Quesnay. ${ }^{2} \mathrm{He}$, too, had a plan for the regeneration of society, but it had not yet been set forth in its entirety. In the work of the marquis "he found the most of his ideas, but expressed in a different form and derived from different principles." The marquis was invited to call upon the doctor in his little room in the entresol above the apartments of Madame de Pompadour at Versailles. The interviews that followed have become historic. ${ }^{3}$

"Never," wrote the marquis to Rousseau, " "did a Goliath go to combat with as much confidence as I

1 Loménie, ii., I68-r 70 ; Ripert, Le Marquis de Mirabeau, 125-130.

2 Hausset, Madame du, Mémoires (Paris, I824), 59, 70, 7 I, 72; Garat, Mémoires historiques sur la vie de $M$. Suard (2 vols., Paris, 1820), 289-291 ; Loménie, ii., I 87-19o.

${ }^{3}$ Streckeisen-Moultou, Rousseau ses amis et ses ennemis, ï., 366 , 367 ; Loménie, ii., I 70-1 74 ; Ripert, 249-278; Oncken, 8-10, I4. 


\section{L' Ami des Hommes}

possessed in going to seek a man who, I was told, had written upon the margin of my book these audacious words: The child has been fed upon poor milk; the strength of his temperament straightens him out often in his results, but he knows nothing about principles. My critic did not spare me, and told me bluntly that I had put the cart before the horse and that Cantillon, as an instructor in political science, was a fool. This blasphemy led me to regard the one who gave utterance to it as a fool, but, reflecting that in every dispute the respective opinion advances by means of reprisals, I restrained myself, broke off the conversation, and, fortunately for mýself, I returned in the evening to question him at my ease. It was then that the skull of Goliath was crushed." It is needless to add that Quesnay was David. It was indeed a small pebble that crushed the giant's skull. When the doctor, replying to his opponent's statement that man was the first cause in the creation of the fruits of the earth, asked if man when he appeared on the earth brought enough bread in his pocket to enable him to live until he had gathered the harvest, the marquis acknowledged that he was beaten. "For," he added, "it was necessary either to suppose that man had licked his paws for eighteen months, like a bear in winter in his hole, or to avow that this creator of the fruits had found, on his arrival, some that he had not sown."

Once conquered, the marquis became a grateful and docile pupil. "I prayed the master," he said, "to explain himself and to instruct me." Quesnay had not yet composed his Tableau économique. This the marquis regarded as a piece of good fortune, for the author, "feeling its utility and necessity, as Genesis says that God saw the beauty of His works," would 
have sent his new pupil to it, and the marquis, who very much disliked "the mechanical application demanded by calculations," would have been discouraged. The doctor was obliged to explain his system, "or, to speak more correctly, the system of nature."1 Converted, the marquis became the interpreter of "the master," "the Confucius of Europe," as he called Quesnay. Abandoning his "error, he consecrated the rest of his time and strength, he devoted his reputation to the publication of the science discovered by Quesnay."2 The victory of the doctor was doubtless due to his energetic and decided character. ${ }^{3}$ Although the two men did not differ fundamentally in the views that they held upon society, Quesnay had a system and the Marquis de Mirabeau had none. The system won. The marquis lost his originality, became a sectarian, and with a remarkable self-abnegation, a semi-religious faith, an enthusiasm almost mystic, he entered upon his apostleship.

At the time the Marquis de Mirabeau was converted to the system of Doctor Quesnay, this system in its entirety had never been made public. In the articles that had appeared in the Encyclopedia, Quesnay had presented in an isolated manner many or most of the ideas that later were to enter into his system, but the form was not yet dogmatic, the expression produit net not yet epitomising the whole doctrine as it did in the completed system. In. the following year, it is true, the Tableau économique was printed, but it can hardly be said to have been published, as the original edition consisted of a single copy. The first public

1 Streckeisen-Moultou, ii., 367 .

2 Dupont de Nemours in the Ephémérides ducitoyen, quoted by Loménie, ii., I 73 .

3 Ripert, 255. 
formulation of the theory was made by the marquis in 1759 in a memoir presented to the economic society of Bern. ${ }^{1}$ The society had offered a prize for the best paper dealing with the importance of agriculture and its development in Switzerland. It is improbable that the marquis was attracted by the prize; he evidently wished to convert the newly founded society to the teachings of his master. What were these teachings?

The system of Quesnay was the natural product of the eighteenth-century mind, that, infatuated with its newly acquired knowledge of the natural sciences, sought for laws everywhere. "Man like all the rest of creation is subject to and included in the essential laws of the natural order." He should "follow nature, the physician of diseases"; he should submit to her guidance, for ex natura, jus, ordo et leges; ex homine, arbitrium, regimen, et coercitio. From these principles, the doctrine of laissez faire, laissez passer was easily deduced. The duty of government was simply "to point out the law to man and force him to obey it." As "no social institution whatsoever could exert any influence, either for good or for evil, upon the distribution, reproduction, and consumption of subsistence," the right of legislation should be accorded "only to the power that causes the sap to rise," and the whole business of man was "to study and to know the immutable laws given once for all and prescribed to nature by this power, to observe them and to effect their observance; such is the nec plus ultra of all human power."2

1 Oncken, 15-22.

2 An excellent presentation of the system is found in Loménie, ii., 281-349; also in Ripert, $250-278$ and $318-353$. For satisfactory shorter accounts, see Lavergne, Les économistes français $d u$ dix- 
But what are these laws? "We have no others," wrote the marquis to Rousseau, "than that of property, personal and real, from which are derived all the liberties possible that do not injure the property of another. It is from the knowledge of this law, which is general and applicable to all cases whatsoever, that is derived our legal despotism that frightens you, but that ought to astonish you no more than the despotism of arithmetical rules, which, once adopted, decide all accounts either made or to be made." As this natural law existed and could be set forth in a series of simple principles "intelligible to all," it was only necessary to propagate the knowledge of the law and keep it alive by instruction. "When the natural order and its essential laws are generally known and taught, they will be the sole despot and the consent of all will watch over their execution." 1 However impossible of realisation the theory may have been, Quesnay and his followers, like the other reformers of the eighteenth century, were desirous of substituting a government subject to law for the government of an arbitrary ruler and of irresponsible ministers. The choice of the expression "legal despotism" to characterise this government was certainly not a happy one. They were looked upon as the defenders of the very abuses that they were attempting to destroy.

The peculiar features of Quesnay's system lay not so much in the assertion that society is governed by natural laws, as in the effort to show how these laws work in the economic world, especially in the world of

huitieme siecle, 58-111, and Oncken, 25-33. I have introduced a number of extracts from the letter of the marquis to Rousseau, in which the system is described. Streckeisen-Moultou, ii., 358-37 I.

1 Streckeisen-Moultou, ii., 365 . 


\section{L'Ami des Hommes}

agriculture. For the system of Quesnay, with its cry "Back to the soil," represented the reaction against the mercantile system that had neglected agriculture and had even developed industry and commerce at the expense of agriculture. ${ }^{1}$ In the importance that he attributed to agriculture Quesnay was thoroughly in accord with the Marquis de Mirabeau. The marquis had taught, however, that population is the cause of wealth and that the main business of government is to increase population, especially country population. Given the men, wealth and power would follow as a natural consequence. Quesnay denied this, asserting that wealth is the cause of population. Wealth, moreover, comes solely from the net gain from agriculture, the only occupation that produces new material. Industry simply works this material over but adds nothing real to it. If the produit net, which depends upon nature, is large, so many more men could be occupied and nourished; if it is small, the conditions of existence are more unfavourable. Everything is determined, Quesnay believed, by the produit net. "Upon the two scales of this balance, you may place and weigh laws, manners and customs, morals, virtues and vices. Everything can be calculated by this table (Tableau economique). Everything that causes your hundred per cent. to decrease, causes society to deteriorate; everything that augments it, adds to social prosperity." This discovery, the marquis believed, would "one day change the face of the universe."

Society was divided by Quesnay into three classes: the farmers, the proprietors of the land, and those engaged in other occupations, designated by the unhappy term sterile. All were dependent upon the

\footnotetext{
1 Brocard, 85-94.
}

2 Streckeisen-Moultou, ii., 360. 
produit net for subsistence. That there might be sufcient to meet the needs of all these classes, it was of the first importance that the products of the farm should sell for a good price. But this high price could not be maintained in France unless the portion of the product not needed in one province could pass readily into another-disappearance of interior toll lines-or the excess not needed in France could be exported to other countries-free trade. The Economists, as they were called in their own day, were thus the agrarians of the eighteenth century. It is curious to note that they expected to obtain by free trade what the agrarians of to-day endeavour to procure by a protective tariff. The possibility of the importation of raw material hardly entered into their calculations. ${ }^{1}$

Commerce and industry were only "branches of agriculture. The gains of the traders of a nation," declared Quesnay, "are not the profits of the nation, . . . for the exorbitant charges of this commerce that enrich our traders, impoverish the nation." $\mathrm{He}$ regarded foreign trade as "a necessary evil, indispensable to sustain the value of products and to avoid the greater evil that would result from their depreciation."2

Finally, as agriculture is the sole source of wealth, the revenues of the government should be derived solely from a tax levied upon the produit net, increasing and decreasing with the increase and decrease of this excess of agricultural production. ${ }^{3}$

With the exception of the doctrine of the single tax, this was the system that received its first connected public exposition in the memoir presented to the

1 Oncken, 31, 32.

2 Ibid., 56 , note 16 , and 57 , note 17 .

3 Theorie de l'impôt, 58, 6r, 63 . 
economic society of Bern by the Marquis de Mirabeau. For the prize, he cared little. "Filled with the desire to see agriculture progressing in all Europe, I considered it my duty to take advantage of this competition to lay an outline of my modest thoughts before those worthy patriots." The position of Switzerland was such that the support of an influential group of men such as composed the society of Bern was well worth winning. Although the memoir of the marquis was the only one that had permanent scientific value, it did not receive the prize. It was, however, influential in clearing the way for the new economic teachings that ultimately gained quite a following among the members of the society. ${ }^{1}$

The memoir was published in the proceedings of the society $^{2}$ and in a volume intended to serve as a continuation of the Ami des hommes that appeared in 1760 . In the same volume the marquis presented an interpretation of the Tableau économique of Quesnay that he had prepared for his own benefit in the effort to grasp all the subtleties of the system. "It was an unhappy idea on the part of the disciple of Quesnay," remarks M. de Loménie, "to choose for the purpose of initiating the public into the doctrine of the master the most arduous and the most obscure of his formulæ. ... The long and heavy commentary that the marquis added to the table, with the pretext of explaining it, only served to render it more obscure; but the new doctrine was, nevertheless, announced and, perhaps, as has been suggested, the fondness of the human mind for mysteries rendered the economic sphinx so much the more attractive to many as it seemed to reveal itself at first in enigmas." 3
1 Oncken, 33 .
2 Ibid., 18.
'Loménie, ii., 203. 
Quesnay did not simply supply the marquis with a system; he also inspired his disciple with a remarkable zeal for the propagation of the system. ${ }^{1}$ At times, the marquis lost heart, "breathing the air of a century inclined to personal interest and feeling himself a sort of moral Don Quixote, when he was truly a citizen." I avow to you," he wrote to his brother on one of these occasions, "that without the example of the opinionated and tenacious doctor, whose studious zeal, apostolic in its kind and continual even to the verge of mania, is never relaxed for an instant, I should let all of that alone. . . . I should be ashamed to have less perseverance than he."

It was shortly after this declaration, that the marquis, urged on by Quesnay, made a daring attempt to induce the French government to reform its financial

1 Among the manuscripts of the marquis in the Archives nationales (M. 784), is a plan for a course in economics prepared for the Choquard pension, in which young Mirabeau passed three years of his life. The manuscript consists of seven pages and bears the title, Education économique chez le Choquard. A few extracts will make clear the character of the document:

"Pour fixer les principes de la science et faciliter la démonstration de ses résultats on a réduit en tableau figuré et arithmétique l'ordre des sociétés et la distribution des subsistances. C'est ce qu'on appelle la tableau économique, et ce que sera mis d'abord sous les yeux des enfants. . . . C'est par l'explication du tableau économique que le Sr. Courts de Gebelin, professeur et démonstrateur de la science économique chez M. l'abbé Choquard, rue et barrière St. Dominique, commencera et continuera son cours d'instruction." After describing the object of the course, the manuscript concludes: "Tel est l'objet du cours économique commencé chez M. Choquard au Ier Septembre de la présente année I767. Persuadé de l'utilité de cette science fondamentale, il se flatte que la société lui sçaura un jour gré d'avoir été le premier instituteur d'un genre d'education important."

Mirabeau did not receive the benefit of this instruction, as he had left the school in the spring of 1767 . (See also Appendix I.) 
system by adopting the theory of the economists. It was in the darkest days of the Seven Years' War, when the resources were exhausted, the armies demoralised and without generals, the navy practically annihilated, the discontent general. ${ }^{1}$ The six-year lease of the direct taxes to the farmers-general was about to expire and it seemed to Quesnay a most opportune moment to put an end to the whole detestable system of farming the taxes. The marquis realised that he would be obliged to utter truths "so terrible for our vampires" [the farmers] that it would be a "prodigy of civic spirit to have dared to go so far and of good luck if everything went off with as little trouble as in the past." However that might be, he was determined "to run the risk, because of a sentiment founded upon principles superior to petty, transitory considerations." The "accomplishment of his vocation" would not be complete without this last effort, and with it he "wished to end his public career."2

The book was addressed to the King under the thin disguise of a series of talks with Louis XIV. It bore the title Theorie de l'impôt. ${ }^{3}$ It is a thorough discussion of the theory of taxation from the point of view of the economists and a scathing denunciation

1 Rocquain, L'esprit révolutionnaire avant la révolution, 2 I9-226. The country was thoroughly aroused on the question of taxation, the parliaments refusing to register new tax edicts. It was in this year that Voltaire wrote, "Messieurs du parlement braleront bientôt!les édits du seigneur roi."

2 Loménie, ii., 216, 217; Oncken, 65, letter of the marquis to Tscharner of Bern, October 29, I760.

3 Theorie de l'impôt (Paris, I76r). The work appeared in December, I760. "Je te dirai que mon ouvrage sangrenu a paru, du moins j'en portai à mes amis de Versailles et en fit tout de suite les présents à Paris."-Correspondance générale, iii., 374. The marquis to the chevalier, Paris, December 9, I 760 . 
of the existing system of tax-farming. It is something more than a simple presentation of the doctrine of the new school of economists; it is a political pamphlet of first-rate importance, that no student of French history in the eighteenth century can afford to overlook.

The marquis introduced his subject by a discussion of the position of the King in society, the limits of his authority, and his right to collect taxes. Having acknowledged that the King was "irrevocably elected sovereign over his people by the right of blood and of nature," he added: "However (permit the expression, since the thing is a fact), you are the first of the employees of your state. All your time and all your activities are pledged to the public. . . . You cannot turn aside for an instant from the object to which you are consecrated, namely public interest, without doing it an injury, without committing a manifest theft; this charge is burdensome, very burdensome in fact, and its weight is the measure of the emoluments of all kinds that were attributed to you. ${ }^{1}$ ... Your power [he boldly announced to the King] is nothing else than the union of the wills of a strong and active multitude to your own, from which it follows that the disjunction of these wills cuts the nerve of your power." 2 The people obey the King "because they hope that he will be worth more to them than he costs them." Where the people lose their rights, there is the limit of the King's empire. When the common interest is destroyed, his empire is shaken. ${ }^{3}$ In almost revolutionary language, he distinguished between the King as an individual and as the head of the state: "The principle of the duty of serving you in war and

1 Theorie de l'impôt, 38, 39 .

2 Ibid., 2.

s Ibid., 9. 
in the cabinet, is derived from the fact that your interests are inseparable from the interests of the public. If by any accident your interests should differ from those of the public, this kind of pay called honour would be improper for your service. If your interests should become absolutely opposed to the interests of the public (it seems horrible to say it, it would be without doubt to suppose it), but, seigneur, it is not the less true that honour would be found in not obeying you."1

The end of taxation is to supply the King with the means that will enable him to secure "abundance and tranquillity at home and security abroad." 2 The whole "secret of finance is that the people shall pay the most possible while at the same time they believe they are paying the least possible." 3 The contributor expects to gain some advantage from his contribution in the form of public service. Diminish the advantage and the contribution diminishes. "In a word, it is a bargain like all others, nothing for nothing is the device of men and God himself has willed it." If the King should attempt "to force an exorbitant and destructive contribution," he would "break the bonds and the constitutional accord of society and of sovereignty." 5

The revenues of the prince should be drawn from a land-tax, for the land alone is the source of wealth. It is "upon the produit net that should be assessed the quota determined by the needs of the state," ${ }^{6}$ and the tax should increase only with an increase of this excess product, for it is an "eternal verity that if the impost exceeds the proportion with the revenue [from the land], it destroys the revenue and in destroying

1 Théorie de l'impôt, 25.

4 Ibid., 7 .

2 Ibid., I 4 .

3 Ibid., , 0.

- Ibid., 56, 6I. 
the revenue it destroys itself." 1 How to determine the amount was a perplexing problem that the marquis did not solve in a satisfactory manner. He was even willing, for a time at least, that the state should not confine itself to the land tax. ${ }^{2}$ The most of the indirect taxes were, however, to be abolished, and with them the marquis would abolish the pernicious system of farming the taxes. In taxation, "any method that tended to introduce a third party, solely with an eye to profit, ought to be abominable and proscribed." 3 It was for this reason that "all ages and all peoples had delivered to anathema and to ignominy the farmers of the public revenues." The farmers, it was claimed, aided commerce and increased the productiveness of the state. On the contrary, the marquis asserted that "they are the worst enemies" of commerce and the "vivification that they contribute to the territory of the state, is like that effected in a poultry yard by the sight of a bird of prey; all scurry about, dodge, hide themselves, flee." 4 The system is painted in the darkest colours; he characterises it as "insulting to natural law," and concludes that "the iniquitous advantage of the farmer" was all that the system had to recommend it. ${ }^{5}$

The assessment and collection of taxes should be in the hands of the people, thus reducing the expenses of collection, increasing the revenues of the prince and interesting the citizens in public affairs. In the treatment of this portion of his subject, the marquis made use of the arguments presented in the memoir upon the provincial assemblies; for provincial and municipal assemblies were to form a part of the machinery for the assessment of taxes. ${ }^{6}$

1 Théorie de l'impôt, 63. 2 Ibid., 2 I 7, 256.

- Ibid., I00, 105.
3 Ibid., roo, 245.

- Ibid., 278-33r. 


\section{L'Ami des Hommes}

His last word was for the farmer of taxes. To render France once more strong and prosperous, to escape from the present evil situation, "it is only necessary to purge our language of a word that our present enemies and our most worthy rivals can express in theirs only by circumlocutions. It is only necessary, I say, to suppress the odious word financier." 1

That the marquis was writing a very vigorous work on finance was no secret; he was even warned that measures were being taken to cause the government to look with disfavour upon so bold an announcement of the truth. ${ }^{2}$ Yet he apparently believed that he would suffer no more personal discomfort from this attack upon the financial system than he had suffered in the past because of his other publications. ${ }^{3}$ The situation was, however, quite different. The book created a sensation, but it did more: it threatened the personal interests of the influential farmers, of a group of which he had written privately, "It is so constant and so strong that the sovereign power is entirely subjugated by it as the sublime porte is by the Janissaries." 4

\section{Theorie de l'impót, 422.}

2 Correspondance générale, iii., 363 . The chevalier to the marquis, Caen, November 24, 1760.

3 "Mon dernier ouvrage fait ici grand bruit et grand scandale à la cour contre ce que j'aurais du penser d'après le succes de mes autres essais." Correspondance générale, iii., 377. The marquis to the chevalier, Paris, December I6, I 760.

4 Ibid., iii., 359. The marquis to the chevalier, Paris, November r 8, 1760. The marquis believed that the nation needed a leader in the attack on the farmers-general: "C'est à quoi je travaille, c'est à quoi j'emploie le franc parler que la providence m'a fait acquérir. Je prends la tête de la colonne, j'en emeute d'autres qui viendront après moi, et je sers le gouvernement plus encore que le peuple. Je serais premier ministre aujourd'hui que je voudrais que mon 
On reading the preface to one of the first copies, the Duc de Nivernois prevailed upon the marquis to suspend the sale of the work until it was known whether the King would take the side of the farmers. ${ }^{1}$ The matter did not remain long in doubt. Monmartel, the court banker, declared that unless the marquis was punished in some way his credit would be destroyed.2 The King was angry at the opening paragraph of the book and felt that the author should suffer for his temerity. ${ }^{3}$ The marquis was arrested and taken to the chateau of Vincennes. $\mathrm{He}$ submitted without complaining and was treated with great consideration. ${ }^{4}$

ouvrage passât avant moi et que je donnerais une attention toute particulière à en susciter de pareils."

1 Correspondance générale, iii., 374. The marquis to the chevalier, Paris, December 9, 1760.

2 Loménie, ii., 221 , quoted from a letter of the marquis.

3 Hausset, Mémoires, r 29-r 3 r.

- Correspondance generale, iii., 385 . The marquis to the chevalier, Paris, December 16, I 760 . As he was arrested by order of the King, the marquis had "nothing to say." "Je ne suis pas piqué, je ne dois pas être, (I) par devoir, (2) par justice, car quoique j'aye du penser que ma manière ne déplaisait pas, elle a toutes les qualités requises pour faire cet effet là, sitôt qu'on veut s'en aviser; ainsi sans avoir péché par le fond, il est juste que je suis puni pour la forme." See, also, the reply of the chevalier in which he approves of his brother's attitude. Correspondance genérale, iii., 386. The chevalier to the marquis, Caen, December 21 , I 760 .

“On n'a jamais arrêté un homme comme celui-là l'a été, en lui disant: 'Monsieur, mes orders ne portent pas de vous presser. Demain, si vous n'avez pas le temps aujourd'hui.-Non, monsieur, on ne saurait trop tôt obéir aux ordres du roi; je m'y attendais.' Et il part avec une malle chargée de livres et de papiers." Madame d'Epinay to Voltaire, quoted by Loménie, ii., 223.

"Je serais fort fâché, comme homme de qualité et homme de bien, que le roi me crat un mauvais sujet: mais on m'assure de bon lieu et très croyable qu'après avoir fait donner sur les doigts pour m'apprendre à bien tenir ma plume, il ne m'en voudrait pas plus de mal." The marquis to Madame de Rochefort, Bignon, December 


\section{L'Ami des Hommes}

The imprisonment was not severe nor was it of long duration, lasting only from the sixteenth to the twentyfourth of December. Through the intervention of his friends he was exiled to his country house at Bignon. He had not destroyed the injurious tax system, but he had increased his own reputation as a bold advocate of reform and was treated as a martyr. His correspondence became both a physical and a financial burden. The exile lasted about two months, the marquis being allowed to return to Paris the last week in February, I76r. ${ }^{1}$

The lesson was not severe, but it had its effect. A period of two years and a half of silence followed " upon matters of the greatest importance to the happiness of the human race." In fact, it was the belief of one of the later disciples of Quesnay that "the progress of intelligence had necessarily been retarded

27, I 760 , quoted by Loménie, La Comtesse de Rochefort et ses amis, ro6.

I found the original of the lettre de cachet, issued against the marquis, among the manuscripts of M. Paul Arbaud at Aix en Provence. It runs as follows:

Mons. Guyonne. Je vous fais cette lettre pour "vous dire de recevoir dans mon Chateau de Vincennes Le Marquis de Mirabeau et de le retenir jusqu'à nouvel ordre de ma part. Sur ce je prie dieu qu'il vous ait, Mons. Guyonne, en sa Sainte garde. Ecrit d Versailles le 14 decembre, 1760.

\section{Louis}

A printed form was used for these orders. I have underlined the words that were written in.

1 Correspondance genérale, iii., 387-42 1 . Letters of the marquis to the chevalier and of the chevalier to the marquis during the exile. Loménie, ii., 227-242.- "Cependant, il s'est cru, il s'est dit le martyr du bien public; et les Economistes comptent cette détention si adoucie et si courte dans les fastes de leur secte, comme les fanatiques orientaux revèrent l'hégire de leur prophète." Mirabeau in Lettres originales, i., I 83 . 
by two years and a half." 1 Although the propaganda through the press temporarily ceased, the doctrine was spread and converts were made by word of mouth and by letter. Among the converts in the next few years, the most important was Dupont de Nemours. The marquis called him "my pupil," because Dupont came to him first for instruction. "We must take care of this young man," said the doctor, "for he will talk when we are dead." 2

As the number of disciples increased, the need of a mouthpiece and of some kind of an organisation was felt. In $176_{3}$, the economists began to publish articles in the Gazette du commerce. In $1_{7} 6_{5}$, the government granted permission to publish a supplement to the Gazette, bearing the title, Journal de l'agriculture, du commerce et des finances. After the third number Dupont became the editor. For sixteen months the Journal was the organ of the economists; in November, I766, the proprietors, dissatisfied with the policy of Dupont, forced him to withdraw. A substitute was found in the Ephemerides of the Abbe Baudeau, who had been converted to the new doctrine. In January, 1767 , this paper became the official organ of the economists. The abbé edited the paper for nearly two years, being succeeded in September, I 768 , by Dupont de Nemours. The paper continued under his editorship until its temporary suspension in 1772 . During the five years of its existence, the paper contained articles from the pens of nearly all of the men who had identified themselves, either wholly or in part, with the sect that looked up to Quesnay as its leader. A large part of the matter was supplied by the editor,

1 Expression of Dupont de Nemours quoted by Loménie, ii., 244.

2 Ibid., ii., 246. 


\section{L'Ami des Hommes}

and it is conceivable that not a little that he contributed was hack work. He was often hard put to it for copy. ${ }^{1}$

The need of organisation was met by the "economic dinners" given by the marquis. "We give," he wrote to the bailli, the I6th of July, ${ }_{17} 67$, "two dinners a week. Tuesday it is the Economists, a sort of sect, very famous, of which I am one of the heads. It is a gathering of distinguished people and of young magistrates, who are easier to instruct than those whom it is necessary to convert; you would see there, however, people of this kind of our own age, like the Duc de Broglie, and also foreigners. In a word, all that turns to the profit of humanity and is the source of more honour to me than expense, for as we are obliged to feed our own people there is always an abundance for dinner." 2

It was in this year 1767 that the marquis endeavoured to add to the reputation of the sect by converting to the faith no less a man than Jean Jacques Rousseau. Although the attempt was not successful, it remains, nevertheless, one of the most curious and not the least interesting episodes in the history of the economists. ${ }^{3}$ Rousseau was in London. His unfortunate affair with Hume made it desirable that he should seek a refuge elsewhere. The marquis, influenced by no other visible motive than the desire to befriend the great man, introduced himself to Rousseau in a most charming and whimsical letter, offering him as a retreat any one of his several estates. After some hesitation, Rousseau accepted the hospitality offered him and

1 Schelle, G., Dupont de Nemours, 32-145.

2 Loménie, ii., 262-265; Oncken, 75, reprint of a letter of Trosne in which he refers to the dinners; Streckeisen-Moultou, ii., 385-387, contains a description of one of the dinners.

3 The letters of the marquis are found in Streckeisen-Moultou, ii., 315-399. See, also, Loménie, ii., 265-278. 
passed some two weeks in June at Fleury-sous-Meudon. During all this time, the new doctrine was mentioned only incidentally. It is true that Rousseau was unable to conceal the suspicion that the marquis "wanted something of him," but his host warned him that if he continued to entertain such suspicions he would lose his esteem. "You have frequently been nourished on bad food in the matter of society," wrote the marquis, "but disinterestedness ought not to appear to you a plant unknown to all others except botanists." It was on the eve of Rousseau's departure, in the letter in which the marquis bids his guest farewell, that the attempt to convert him began. The marquis begs Rousseau as a mark of friendship to read the book that he sends him. "I wish you to know me and the science that occupies my attention at least by an outline." Rousseau finds the matter distasteful, but the marquis endeavours to draw him on, assuring him that "the economic language is a new alphabet" and that it was "impossible to read it at the first glance of the eye." He endeavours to interest him by telling him the story of his conversion, in answer to Rousseau's protest that "at his age no one is ever sincerely converted." The labour was in vain. The author of the Contrat social revolted at the expression legal despotism and found the whole system so abstract and impossible of realisation that he had no taste for further investigation. The persistence of the marquis finally drew forth a pathetic appeal, in which Rousseau, " prostrating

" himself at his feet," begs him "to have pity upon his condition and his misfortunes and to leave in peace his dying head." "Love me ever, but do not send me any more books." He even refused later to allow the marquis to publish anonymously the letters in which the 
two had discussed the science. The marquis did not change his kindly attitude toward Rousseau in spite of the failure, but again offered him the use of the house at Meudon and promised not to talk economics. The offer was not accepted, Rousseau's old suspicious attitude returned, and the correspondence came to an end.

But if the attempt to convert Rousseau had not been successful, the marquis found compensation elsewhere. Several of the crowned heads of Europe had been won over to the new theory and one even attempted to make a reality of the produit net in the administration of the finances of his state. Gustave III. of Sweden sent the marquis the cross of grand commander in the agricultural order that he founded; the Markgraf von Baden came to Paris to receive instructions in the science from him and later contributed to the Ephémerides; to the Grand-duc de Toscane, the marquis dedicated his Economiques and was frequently consulted by the ministers of the duke. It was the Markgraf von Baden who had a short but disastrous experience with the produit net. ${ }^{1}$

The teachings of the school-or some of them at least-found acceptance with men prominent in government circles, and the economists were directly interested in the attempt made in the years 1763 to 1770 , to render free the transportation and exportation of grains. Edicts were issued in ${ }_{17} 6_{3}$ and ${ }_{7} 764$ removing nearly all the restrictions that had interfered with the free movement of cereals within the country and across the frontiers. The time chosen for the experiment was a most unfortunate one. Crop failures rendered grain scarce and raised the price. The evil was attri-

1 Loménie, ii., 278-280; Ripert, 42 I-430. 
buted to the edicts and the economists were attacked from all sides. The government yielded and Terray, practically in accord with public opinion, in $I 770$ abolished the edicts. ${ }^{1}$

It was a severe blow for the economists. They had lost the support both of the government and of public opinion. All their work must be done over again. "The ministry of Terray was marked by a very decided reaction against their doctrines and liberal tendencies. Their writings were carefully watched, the editing of the Ephemerides was interfered with and the publication finally prohibited in I772."2

I have traced the life of the Marquis de Mirabeau as a publicist to the coup d'etat of I77I, presenting such facts as will make it possible in future chapters to make clear the influence that his life and his teachings had upon his son. I have endeavoured to show the spirit that filled his writings and the ends that he aimed at. He felt strongly the responsibility that rested upon him as a member of society and as a citizen of France. An opponent of arbitrary government and a critic of worthless kings, he advocated a government based upon law and looked upon the king as the first servant of the state. Public office he treated as a public trust and condemned the office-holder who did not return an adequate service to the state. ${ }^{3}$

$$
{ }^{1} \text { Loménie, ii., 254-262; Ripert, 354-375. 2 Ripert, } 375 .
$$

s"Le public ne doit à ses agens les plus nécessaires et les plus dépourvus que la subsistance et rien aux autres. Or à quel point serait le désordre si l'on soudoyait les emplois qui ne seraient point remplis, si l'on en entassait plusieurs sur les mêmes têtes dispensées d'en exercer aucun; si l'on en rendait les émoluments plus ou moins étendus au gré de la faveur ou d'une habitude fatale? Ce ne serait autre chose, que dépouiller le labeur public pour revêtir et gratifier l'oisiveté privée.... Le peuple verrait dans les grands, dans les favoris non seulement des citoyens indignes renonçant à tous les 


\section{L'Ami des Hommes}

Opposed to the extreme interference of the government in all affairs of life, he would make agriculture, industry, and commerce free, believing that they could best care for their own interests. The decay of France he attributed to the neglect of agriculture and to the decay of morals, and for both of these evils he proposed a remedy. Slavery he condemned. $\mathrm{He}$ was frank in his criticisms and posed as the adviser of kings and princes.

The most of these traits will reappear in the work of his son. The marquis was more dogmatic after he had come under the influence of Quesnay; he was more conservative and more respectable than the famous orator, but the characteristics that their work possessed in common far outweighed the differences due to age and environment.

devoirs de l'humanité, à toutes les loix de la société qui leur ordonne un travail relatif; mais encore des brigands civilisés empressés à se partager ses dépouilles."-Théorie de l'impôt, 47. 


\section{CHAPTER VII}

\section{L' ENFANT TERRIBLE}

$\mathrm{O}^{\mathrm{N}}$

$\mathrm{N}$ the ninth of March, $\mathrm{I} 749,{ }^{1}$ at the Chateau de Bignon, an heir was born. to the Marquis de Mirabeau. The words, "Don't be frightened," that fell upon the father's ear as he entered the chamber, were intended to prepare him for his first meeting with an unusual infant. "Destined to be the most turbulent and the most nimble of youth, Gabriel was born with a twisted foot; to be the most eloquent of the men and of the orators of his century, he was tonguetied at birth"; the dimensions of his head, "his size and vigour, were unprecedented, and two molar teeth were already formed in his mouth." 2

1 The date of birth is found in the record of the baptism published by Pallain, M. G., La statue de Mirabeau (Paris, Plon et Cie., 1883), 29. "Cejourd'hui seixième jour de mars mil sept cent quaranteneuf, je prêtre curé soussigné suppléé les cérémonies du baptême à Messire Gabriel-Honoré de Riqueti, né le neuf de cé mois et ondoyé le dix, fils de haut et puissant seigneur Messire Victor de Riqueti, Marquis de Mirabeau, comte de Beaumont, seigneur de Bignon et autres lieux, et de haute et puissante dame Marie-Genevieve de Vassan, ses père et mère de légitime mariage. Le parrain qui a donné le nom de Gabriel-Honoré est haut et puissant seigneur Messire Gabriel de Chouly, marquis de Permangle, et la marraine haute et puissante dame Anne-Thérèse de Ferrières de Sauveboeuf, marquise de Vassan, lesquels ont signé avec moi."

The register is signed by "Anne-Thérèse de Ferrières de Saulveboeuf de Vassan; Permangle; Mirabeau; F. J. B. de Missilien (sousprieur des Jacobins de Sens); Deplace (curé de Bignon)."

2 Montigny, Mémoires, i,, 237, 238. M. de Montigny drew his 


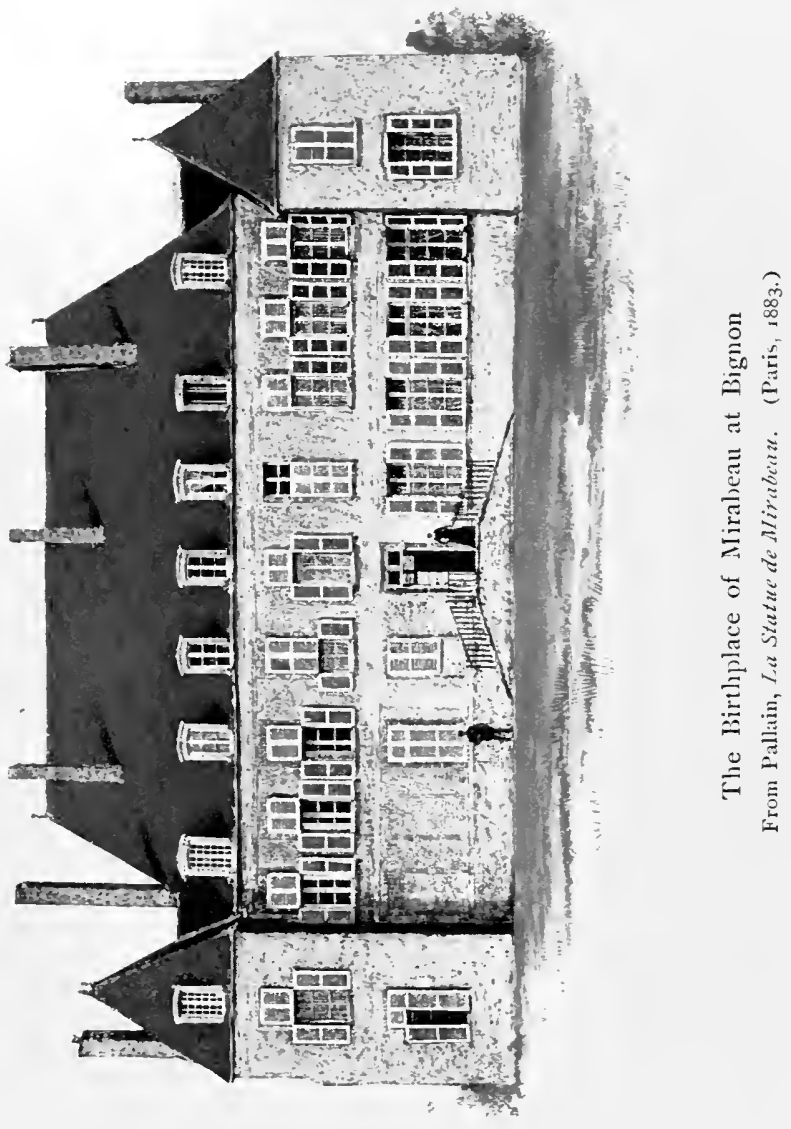




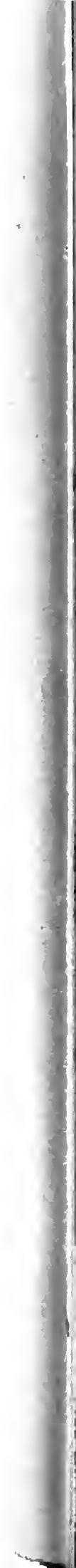


Although the marquis, influenced by a superstitious feeling-his first-born son had died shortly after the fête given to celebrate his birth ${ }^{1}$ - forbade all village festivities, the peasants of the surrounding parishes gathered at the chateau to testify their joy at the happy event, crying that "if he resembled his father it would be a long time before they would eat acorns as did their neighbours of Egreville the past year." 2

The little village of Bignon, ${ }^{3}$ the birthplace of Mirabeau, lies between Nemours and Montargis, not far from Paris. The chateau, with its grounds and park, the favourite summer residence of the marquis, was in the outskirts of the village, "hidden in the folds of a narrow valley, a veritable oasis in the long and monotonous plains of wheat of the Gatinais." The chateau no longer exists, but "the alleys of the old park are those in which young Mirabeau played, the trees are those that sheltered him." 4 Here, for the most part, his childhood was passed. He "loved

information from letters written at the time by the marquis to relatives and friends. Mirabeau refers (Lettres originales, iii., 3) to the fact that he was born with two teeth and adds, "ce qui est assez singulier, mais pas cepenđant très rare." M. Mouttet (Mirabeau en Provence, I 5) states that Louis XIV. and Mazarin possessed the same peculiarity and remarks, "Les anciens disaient que c'étaient signe de grandeur future."

1"Un premier enfant mâle était mort en bas âge, dix-huit mois auparavant, par suite d'un accident étrange que nous avons déjà mentionné: il s'était empoisonné en buvant de l'encre. '-Loménie, iii., 2.

2 Montigny, Mémoires, i., 239, quoted from a letter of the marquis to the Duc de Nivernois, April I $5,1749$.

3 By a decree bearing the date December I3, I88I, and signed by Waldeck-Rousseau, as Minister of the Interior, the French government changed the name of the village to "Le Bignon-Mirabeau," in honour of the great Frenchman who had been born there. See the document in Pallain, La statue de Mirabeau, 43.

4 Loménie, iii., 20. 
Bignon, not only as the place where he had been born and reared, but as his favourite estate, his preferred residence." 1

With the exception of a single sentence, found in a letter of the marquis, any references to the infancy of Mirabeau that may have existed have disappeared. Writing to the bailli, February Io, $175^{\circ}$, the father referred to the child in the following words:

"I have nothing to tell you about my enormous son, unless it be that he beats his nurse, who repays him with interest, and they cuff each other to the best of their ability. They are two fine heads together." 2

At three years of age, Gabriel was attacked by the small-pox in a very malignant form. For several days his life was in danger. His mother, who "had many recipes," full of solicitude and distrustful of the physicians, rashly applied homemade lotions and ointments. to the tumefied face. The results were disastrous; the countenance of the child was profoundly furrowed

1 Loménie, iii., r 9.

2 Montigny, Mémoires, i, 240, quoted from a letter of the marquis to the bailli of February 10, r754. A letter of the date of July 24, I $76_{3}$, contains a description of Mirabeau's nurse. It was written by the marquis to the Comtesse de Rochefort: "La verte et robuste maréchale dont vous me parlez est celle qui a nourri mon fils. C'est une maîtresse femme, qui a bien élevé deux couvées d'enfants, soutenu la forge quoiqu'en viduité, car ayant essayé de deux maris, et voyant qu'ils ne voulaient pas durer, elle s'en est tenue là. Elle a tout payé, et tout liquidé, maintenu ses garçons, mariés, dans l'obéissance; elle fait des nourrissages; des troupeaux d'oies qui feraient l'exercise à la prussienne, des dindons capables de rendre un arrêt sur l'inoculation [reference to the decree of the parliament of Paris of June 8, I763, asking the opinions of the faculties of theology and of medicine of Paris upon inoculation] tout en battant ailleurs l'enclume, par passe-temps, attendu qu'elle dit que cela allonge les bras."-Montigny, Mémoires, i., 240, note 2. 


\section{L' Enfant Terrible}

and scarred. ${ }^{1}$ This incident was one of the most baleful in Mirabeau's life. His pock-marked features won him little favour in a family famous for the beauty of its men, and his disfigured face was evidently not the least important of the influences that worked to his disadvantage in his father's mind. He refers not infrequently, in later life, to his misfortune, sometimes in jest, ${ }^{2}$ at other times with a deep underlying strain of seriousness. He calls himself "as ugly as Vulcan" 3 ; he speaks of his "sad countenance" 4 and of "the chiselling with which Dame Nature has ornamented me." 5 He was always deeply interested in vaccination. Writing from Vincennes to the Comtesse de Mirabeau, he urged that the operation be performed at once upon his son, adding, "The certainty of not being disfigured ought to count for something; I shall be happy if my son is not as ugly as his father." 6 Some months later, in a letter to Sophie de Monnier, he expressed the hope that love would blind their daughter to the scars that the disease had left upon his face. ${ }^{7}$

It is only in 1754 that we are able to seek information in the most important of all the sources upon Mirabeau's

1 Montigny, Mémoires, i, 24 r. M. de Montigny drew this information from the Mémoires of the marquis.

2 "Quant à la beauté de Gabriel-Sophie (qui me resemble! donc elle est belle; car il n'y a rien de si beau que moi, et Madame Elizabeth m'a demandé un jour si j'avais été inoculé), j'en serai toujours plus que content quand elle se portera bien."-Lettres originales, ii., $4^{\mathrm{I}} 3$.

3 Ibid., iii., 427.

Ibid., ii., 87 .

5 Ibid., ii., 95.

- Lettres originales de Mirabeau, i., 216.

'Addressing the infant, he wrote: "Va, sois aimée seulement la moitié autant que j'aime ta mère, et nous verrons si cela ne bouchera pas à tes yeux bien des trous de petite-vérole."-Ibid., ii., 109 .

vor. $1 \rightarrow 9$ 
early life, the correspondence between his father and his uncle. ${ }^{1}$ After carefully reading this voluminous correspondence, I am led to the conclusion that an uncritical treatment of the sources has vitiated to a greater or less degree all past attempts to describe the early relations between Mirabeau and his father. The knowledge of the marquis's brutal, at times almost inhuman treatment of his son in later years had made it difficult, often impossible, for historians to examine with unbiased minds the evidence upon which every reliable account of Mirabeau's childhood must rest. When their work is free from this distorting influence, it falls short of the best results attainable, through a failure to make allowance for the important rôle played by time. The dislike of the marquis toward his son increased with the boy's years and was more or less modified by circumstances. It is possible and desirable to trace this growth and these changes more accurately and more completely than has been done. The success of such an undertaking will depend largely upon a careful and critical treatment of the evidence. The date of the record here acquires a preponderant influence in determining the value of its contents. A statement made by the marquis in I 780 is not always convincing evidence upon his mental attitude in I754. The chronological order must be carefully observed in grouping the facts to bring out clearly the successive phases in the growth of the marquis's dislike for his eldest son and the variations in his sentiment toward the boy.

In the correspondence between the marquis and the

1 Correspondance générale entre le Bailli et le Marquis de Mirabeau: This is the title given to the collection by M. Guibal and the one by which I shall refer to it. 
bailli, the letters written in the ten years from 1754 to 1764 contain very few references to Mirabeau. It is hardly correct, and somewhat misleading, to say that he was "one of the most frequent subjects of discussion," 1 when it is noted that in the year 1754 , during which the brothers exchanged thirty-three letters, filling more than two hundred and seventy quarto pages, there are but four brief references to the boy by his father and one by his uncle, making perhaps a page in all. In the letters for 1755 , filling nearly three hundred pages, the child is not mentioned. This single reference to his nephew in two years would hardly justify the statement of M. de Montigny that Mirabeau occupied "greatly" 2 the attention of his uncle. It ought to be clear that until his fifth yearjudging from all the evidence that we possessMirabeau did not engage more of the attention of his father than the ordinary child would receive from his father.

I believe it is equally clear that during the first ten years of the boy's life the marquis displayed no marked dislike for his son; on the contrary, the evidence seems to indicate that he was rather favourably disposed toward him. "Your nephew," he wrote the $\mathrm{r}_{3}$ th of May, I754, "is large and strong; we never lose sight of him and his education is excellent, beyond anything that you can imagine. His knowledge is the talk of all Paris, and yet," added the marquis, evidently desirous of giving his brother an honest description of the child, "as he is your child as well as mine, I will say to you that up to the present time he has little character; few vices, apart from a mechanical inequality, that would show itself if allowed

1 Loménie, iii., 7 .

2 Montigny, Mémoires, i., 244. 
to do so; but little sensibility; it is sand that retains no impressions; however," he concludes sensibly, "he is only five years old." 1 "Your nephew has all at once become roguish, remarkably inquisitive, and very active," runs a letter of the same month. "He keeps us busy, but we have an eye on him, and he is in excellent hands." 2 In October, he assures the bailli that " his nephew is as ugly as Satan's own, but"there is some compensation - "he is in very good hands and will, I believe, come out all right." 3 In his reply to the earlier letters, the bailli expressed himself in a characteristic manner concerning his nephew:

Give my warmest thanks to M. Poisson for the education that he is giving our child. May he make of him an honest man, a sturdy citizen, that is all that is necessary. With these qualities, he will make that race of pigmies that play the giant at court tremble before him."

Little did the bailli realise how completely the man would fill the rôle assigned to him as a child !

A most charming anecdote of Mirabeau's childhood, containing striking evidence of his precocious development, is recounted by his father in a letter of December seventeenth:

The other day Poisson told him to write anything that came into his head; I transcribe here what he wrote and shall have it framed for him, that he may remember that at five years and a half he was acquainted only with

1 Correspondance générale, i., I3. The marquis to the chevalier, Paris, May I 3 , 1754 .

2 Ibid., i., 33. The marquis to the chevalier, Paris, May 24, I754.

3 Ibid., i., 229. The marquis to the chevalier, Paris, October 9, I 754 .

4 Ibid., i., 264. The chevalier to the marquis, Guadeloupe, August II, I 754. 
what is good. Here is the composition: "Monsieur de Mirabeau, I beg you to pay attention to your writing and not to make blots on your copy-book, to take notice of what is done, to obey your master, your father, your mother; not to be obstinate; no evasions, honour above everything; attack nobody unless you are attacked yourself; defend your country; be not disagreeable to the servants, nor be familiar with them; conceal the faults of your neighbour, because that may happen to you yourself."1

When he was seven years of age, Mirabeau was confirmed at Bignon. The marquis was absent in Paris and the rôle of master of ceremonies fell to the bailli. The services were conducted by no less a man than a French cardinal. In a letter of the 26 th of September, the bailli gave an account of the affair to the marquis:

The cardinal brought with him five priests and an army officer, so that I was obliged to occupy the chamber where the verger formerly lodged. Everybody supped well and dined well. Your son was confirmed at the head of six hundred good little people, and Poisson's little one first of the little girls. The ceremony took place in the warren, to the great disappointment of the cure, who had prepared a fine harangue; he told the cardinal so, who graciously replied that he felt complimented by it, and then laughed heartily when I added that it was so much clear gain both in the matter of expense and for the patient. The cardinal was very polite and paid much attention to your children. The little chevalier laughed at seeing so much red. ${ }^{2}$

It was perhaps on this occasion that took place the

1 Correspondance générale, i., 209. The marquis to the chevalier, Paris, December I 7, I 754 .

2 Ibid., ii., 197. The chevalier to the marquis, Bignon, September 26, x 756 . 
incident related by Mirabeau in the letters written at Vincennes:

For myself, when it was explained to me, at eight years of age, that God could not make incompatible things, as, for example, a stick that had but one end, I asked if a miracle was not a stick that had but one end. My grandmother never pardoned me for that. ${ }^{1}$

After the confirmation, the bailli remained for several weeks at Bignon, assisting Poisson in disciplining his charge. A report made to the marquis, then in Paris, would seem to indicate that the good Poisson was one of the first victims of the seductive manner that was to characterise Mirabeau in future years. "M. le comte," wrote the bailli, "has been doing penance for the past four or five days, and in truth, he has merited it not a little. I serve Poisson as an additional instrument, for when he has promised indulgence, I enable him to avoid granting it without breaking his promise, and I stand for rigorous discipline." 2 The marquis approved of his brother's action and appreciated his willingness to share in the vexatious labour of educating the heir of the Riqueti. It is possible to trace in his reply the beginning of the tendency, finally to become fixed, to treat the boy as incorrigible, as irredeemably bad. He thanked the bailli "for bringing pressure to bear upon M. le comte. I know," he added, in a tone of despair, "that bisogna compatir and that I should give up the idea that that individual has in him the type of our race; but, by all that 's holy, he shall abjure his fondness for lying or I will find means of annulling it with

1 Lettres originales de Mirabeau, iii., r 30.

2 Correspondance générale, ii., 2 I9. The chevalier to the marquis, Bignon, October ro, I 758 . 
disgrace." 1 It is hardly necessary to infer from these utterances either that Mirabeau was uncommonly depraved or that the father at this time hated his son. The "mensonge de prédilection" is a youthful infirmity like the mumps and the whooping-cough, but likely to be treated too seriously by a father of pedantic character.

M. Poisson, who for eleven years was Mirabeau's instructor, was a most estimable man. A reverse of fortune had obliged him to seek a place and the marquis had received him into his family with his wife, two children, and a domestic. He granted him I200 livres a year and placed him in charge of his son, who was then four years and a half old.2 M. Poisson was treated as a friend and equal and highly esteemed both by the marquis and by the bailli. An enthusiastic characterisation of him is found in a letter of the marquis to the Comtesse de Rochefort:

Imagine a man truly superior in bearing, in mind, and above all in heart, equally fit for great and for small things, master in all the liberal arts, born with that sort of talent that embraces the knowledge and practice of all the mechanic arts, a man, in fine, whom, during five years of daily intercourse, I have found weak and intercadent in nothing and whose excellent heart is filled with unbounded devotion to me. ${ }^{3}$

In the autumn of $\mathrm{r} 757$, Poisson fell ill of a fever. The marquis watched over him with all the solicitude

1 Correspondance générale, ii., 225. The marquis to the bailli, Paris, October 18 , I 756.

2 Mémoire of the marquis to Malesherbes, March or April, ${ }_{776}$. Archives nationales, K. 164, 2, 92.

3 The marquis to the Comtesse de Rochefort, September 27 , I 757, quoted by Loménie, iii., I 4 . 
of a brother: filling his letters with detailed accounts of the progress of the disease and with gloomy forebodings of his irreparable loss should the illness have a fatal termination. In the midst of all his troubles, he wrote to the bailli: "It is my son alone that embarrasses me. The women spoil him. He is naturally very active, like all children of that age, and I cannot saddle him upon Poisson, now in a state of convalescence." 1 On the $13^{\text {th }}$ of October, the condition of the sick man had become so critical that the marquis gave up all hope. "This event breaks my heart," he wrote. "It is a great loss for all of us. His attachment to you and to me was unique. As often as he was conscious, he gave expression to his tenderness for me with his voice, his hands, and his eyes; then this poor family." 2 Undoubtedly the thought that the whole care of this enfant terrible might, in the future, fall upon him added to the sharpness of his grief. The concluding words of his letter, "I keep my son attached to my girdle," 3 graphically describe his situation. The bailli was as much concerned as his brother over the outcome of the illness of "the poor Poisson," as he called him. "I avow to you," he wrote, "that his condition pains me, and that of his family, if it loses him." He spoke of his affection for all this family, "whose well-being and maintenance appear to me to have entered into the round of my duties." 5

But Poisson did not die. He lived on for many

1 Correspondance génerale, ii., 357. The marquis to the chevalier, Bignon, October 10, $1757^{\circ}$.

2 Ibid., ii., 363. The marquis to the chevalier, Bignon, October 13,1757 .

3 Ibid.

4 Ibid., ii., 368 . The chevalier to the marquis, October 2 I, I 757 .

s Ibid., ii., 364. The chevalier to the marquis, October 8, I757. 


\section{L' Enfant Terrible}

a year, enjoying the friendship and confidence of the brothers, playing the rôle of mentor and tutor to the young Mirabeau until the task seemed beyond him. Poisson, at times, acted as master of revels. On the I 7 th of June, I757, the marquis invited the Comtesse de Rochefort to a sort of fête to be given in honour of his mother. "It is the work of the governor of my son, an invaluable author and actor of follies of that kind. You will see in one of the rôles a little monster that they say is my son, but who, were he the son of old La Thorillière, could not be more naturally devilishly quick in learning his part and a droller comedian." 1

No change in the sentiment of the marquis toward his eldest son is noticeable in the single anecdote reported for the year $175^{8}$.

My son [he writes], whose body grows, whose chatter increases, whose face grows ugly in a marvellous manner, is ugly avec recherche et prédilection. His mother made to him yesterday some anti-declaration in the name of his future wife; he replied that he hoped that she would not look at him au visage; his mother asked ingenuously, "Where would you have her look at you?" and all began to laugh; he retorted: "The inside will help the outside"; and we laughed the more merrily, without noting that there is matter for thought in this retort of a child. ${ }^{2}$

1 Montigny, Mémoires, i., 249, quoted from a letter of the marquis to the Comtesse de Rochefort, June I 7, I 757. I would call attention to what is said in the "Critical Bibliography," at the close of this volume, upon the value of the Mémoires of M. de Montigny. I feel distrustful of any quotation made by $M$. de Montigny that $I$ have no means of verifying. Both date and language may be incorrect.

2 Letter of the marquis to the Comtesse de Rochefort, September 2I, I 758 , quoted by Montigny, Mémoires, i., $25 \mathrm{I}$. 
When ten years of age, Mirabeau was attacked by an intermittent fever that lasted several months. In announcing the illness to his brother the marquis added that "the worst symptom is that he is as reasonable as if he were thirty years old and that Poisson is well pleased with this feature." 1 The bailli was little concerned at the illness of his nephew, replying that it "grieved" him, but he "hoped that nothing would come of it." 2 Three weeks later, the marquis announced that his son was better and described the vigorous treatment that he had given him. "Finally," he concluded, "there has been at the same time a great revolution in his character and he promises to become a very pretty subject, showing no longer any trace of ill-humour, of baseness, or of falsehood." 3

In October and again in November of the same year we have two brief characterisations of Mirabeau from his father's pen:

This child [he wrote to Lefranc de Pompignan] although turbulent, is gentle and facile, but of a facility that inclines to worthlessness. As he bears a striking resemblance to Punch, being all belly and back, he appears to me well fitted to play the part of the tortoise; he presents his shell and permits you to strike." 4

In another letter, the marquis showed considerable

1 Correspondance générale, iii., I32. The marquis to the chevalier, Bignon, August 23, I 759.

2 Ibid., iii., I37. The chevalier to the marquis, Bayeux, I759.

3 Ibid., iii., I40. The marquis to the chevalier, Bignon, September I 4, I 759 .

The bailli replied expressing his pleasure at learning "que ton fils ainé en guérissant par le corps parait se guérir aussi par le coeur sur lequel à son age il n'y a rien de formé."-Ibid., iii., I4 I , Avranches, September 25, I 759 .

4 The marquis to Lefranc de Pompignan, October 6, I 759, quoted by Montigny, Mémoires, i., 252. 


\section{L'Enfant Terrible}

irritation at the action of his son, who has indulged too freely in promiscuous almsgiving:

This big bouncer of a Gabriel goes about begging for money in order to give it away to beggars, following the example of his mother, in spite of all that I can say to them, that there is nothing so out of place, so absolutely contrary to my principles, as these manual charities, that make people poor instead of relieving them of their poverty. ${ }^{1}$

I have presented all the evidence that I have been able to discover upon the first ten years of Mirabeau's life, showing the attitude of his father toward him. The attitude was not a sympathetic one, although not unfriendly. The ugliness of the boy constantly fixes the attention of the marquis; he observes and describes him as he might some strange and interesting wild animal, but as a rule there is more whimsical humour than bitterness in his descriptions. He is determined to make an honest man of him if possible, but his task is not an easy one and at times he despairs of success.

The problem of educating such a child as Mirabeau might well have filled with despair a father much better fitted for it than the Marquis de Mirabeau. I have already referred to the treatment that he had received at the hands of his own father and to the theory built up on personal experience that a father should not be the companion of his children. This was, probably, the most unfortunate theory that he could have adopted in the education of his eldest son. What the boy wanted, and what he did not get, was sympathy. The Baron de Gleichen, an intimate friend

1 The marquis to Lefranc de Pompignan, November 5, I759, quoted by Montigny, Mémoires, i., 252. 
of the family who had observed at close range the efforts of the marquis, wrote some years later:

The despotic, debasing and hateful manner in which this son was treated and rendered desperate in the paternal house, because he was ugly and could not be conquered by punishment, stifled in him the sentiments of honour and ambition that ought to be found at the bottom of every courageous soul, increased the violence of his passions, and sharpened his intellect, so unlike and so superior to that of his parents. I often told them that they would make a great rascal when they might make a great man of him. He has become both. ${ }^{1}$

Mirabeau complained frequently of his father's unsympathetic attitude.

I might say [ran a memoir addressed from Vincennes to the marquis] that from the time of my infancy, of my first steps in the world, I received few marks of your kindness; you treated me with rigour before I deserved it; that you should have seen very early that this manner of treatment excited all my natural passion, instead of repressing it; that it was equally easy to soften me and to irritate me; that this first road conducted me to the goal, that the second turned me aside from it; that I was not born to be treated like a slave. ${ }^{2}$

The father himself tells us that this had been the complaint of Mirabeau from his earliest childhood. The boy wished to be reasoned with. Poisson was "only too much of a reasoner," and "I myself," went on the marquis, "reasoned with him in a manner unique for a father." $3 \mathrm{He}$ had, however, no confidence in

1 Gleichen, Le Baron de, Souvenirs, i 6.

2 Lettres originales de Mirabeau, i., 295.

${ }^{3}$ Correspondance génćrale, vi., 332 . The marquis to the bailli, May 29, 1770. 
this method. His "maternal penchant for pedantry, which annoys men that have attained their growth and spoils those that are being formed,"1 prevented him from making frequent application of it. The bailli, while acknowledging that Poisson appeared to him "a man of merit," was not fully satisfied with his methods. "I fear that he did not allow enough of what the Italians call sfogo to the lively temperament of the child, and that in restraining it he encumbered the furnace, so to speak." 2

All that the historian would seem to be justified in inferring from the statements of Baron von Gleichen, of Mirabeau, of his father and his uncle is that the moral training of the boy was characterised by too much pedantry, by insufficient knowledge of boy nature and by lack of sympathy in dealing with it. Nothing seems to justify the additional inference that the marquis followed this method becase he hated his son; it was the most natural method for a man of his temperament and his past to adopt in dealing with such an unusual child.

Of Mirabeau's life during the two years that followed his illness, we know nothing. ${ }^{3}$ In the correspondence

1 Correspondance générale, vi., 352. The marquis to the bailli, Paris, June $14,{ }^{7} 770$.

2 Ibid., vi., 349. The bailli to the marquis, Aix, June 6, 7770 .

3 The Mémoires of M. de Montigny contain (i., 254, 255) quotations from the letters of the marquis to Lefranc de Pompignan, to the Comtesse de Rochefort, and to the Duc de Nivernois, but I have not ventured to use them, as I was unable to verify either the dates or the text. On the same pages are quotations from letters of the marquis to the bailli; these I have compared with the manuscript copies. The text is so badly mutilated as to be useless, while the dates have been changed from $x_{76}$ to ${ }^{1} 76 \mathrm{r}$. Are the text and dates of other quotations found in the Mémoires, that I have not been able to verify, any more reliable than these? 
for 1760 and 1761 , no mention is made of the boy. In the following year, he occupied the attention of the brothers more than ever before, although the letters of the bailli still contain very few and very brief references to his nephew. The marquis's opinion of his son grows constantly more unfavourable. Many influences worked together toward this end. First of all, the boy was approaching adolescence, and during this period his character, always a bundle of contradictions, became more incomprehensible than ever to his father and filled the paternal mind with the darkest forebodings. What was to be the future of the house whose heir possessed such a character? This was the question that constantly recurred to the mind of the marquis; his answer to it was not at all of a reassuring nature. Furthermore the Marquise de Mirabeau had left her home in I 762 never to return; her place had been taken by the young and attractive Madame de Pailly. This was clearly a new influence that worked to the disadvantage of the boy, but in what manner and to what extent, we have no means of knowing.

In 1762 , in discussing the administration of the family estates, the marquis exclaimed: "By my faith, unless some miracle occurs, I doubt much if my eldest will be the kind of a man to bear alone the burden that I have been bearing and which, because of its nature, ought to be divided." 1 As it was not likely that the boy would be equal to the task and as the task was unusually difficult, it appeared to the marquis to be wise to consider the possibility of dividing the burden.

I had thought [he wrote to the bailli] that if my eldest

1 Correspondance générale, iv., 250. The marquis to the chevalier, Aiguesperse, September 29, 1762. 


\section{L'Enfant Terrible}

was an excellent subject it might all [the estates] fall to him. But as with much talent and wit he has many more defects inherent in his substance, it is likely that giving him Paris, the court, and Limousin, I shall make of Boniface [the younger son] a purely Provençale branch, by marrying him in that region." 1

This plan was not, however, adopted at once. In spite of everything, the eldest boy might amount to something, although the signs all pointed the other way. If this son, "whose education is growing very expensive, who is supplied at present with fencing masters and tutors, is not a very great subject, a thing that is not too threatening," 2 the marquis will carry out the plan that has already been mentioned. But even this plan might be rendered impossible by the character of this "fiery, wrong-headed eldest son, each day more troublesome and insane." 3 It was not, however, simply the unpromising character of Mirabeau that led his father to dwell upon the idea of dividing his estates. His own painful daily experiences had taught him that "it was impossible for the same man to manage with wisdom and justice before God and man the two parts of a heritage so heterogeneous and distant from one another as are our patrimony in Provence and the vast establishments that my children ought by natural right to inherit in Limousin." 4 Even were the estates divided, the share of the eldest son would be more than all that the marquis had

1 Correspondance générale, iv., 263. The marquis to the chevalier, Paris, November 25, I 762.

2 Ibid., IV, 266. The marquis to the chevalier, Paris, December 22,1762 .

3 Ibid., iv., 286. The marquis to the chevalier, Paris, March $3^{\mathrm{I}}$, I 763 .

4 Ibid. 
inherited. But "I fear greatly," ran the closing words of this letter, "that he will never be anything but a lunatic, and what is worse, wrong-headed, a thing that cannot be remedied. God is over all."

In $\mathrm{I}_{7} 6_{3}$, the repugnance of the marquis toward his eldest son, his pessimism concerning any possible improvement in the boy's character, became more pronounced. At intervals, he took a more hopeful view of the situation, but his mind quickly resumed its old attitude. He spared no pains with his education. It was not only a matter of conscience, of duty, with him: it was a matter that concerned the whole future of his race and no means must be left untried to make a man of this "unpromising subject," as the marquis called him. All this and more than all this is revealed by a letter of the marquis to his brother.

The oldest of the boys [he wrote] for whom so great care has been taken and for whom I have incurred expenses without limit, that I might have no reason to reproach myself, might well be called in good French a child born under an evil star, and appears to me, at least up to the present time, likely to become nothing but a lunatic, almost invincibly maniac in addition to all the vile qualities of his antique resemblance. Education, and above all the fear that he has of me, conceals externally many of these qualities; but as he is being instructed at present by a number of choice masters, and as all, from the confessor to his comrades, are so many correspondents that supply me with information, I see the nature of the beast and I do not believe that anything can ever be made of him. ${ }^{1}$

Two months later, he refers to the boy, now in his fifteenth year, as "very much of a caterpillar and,"

- Correspondance générale, iv., 294. The marquis to the bailli, Paris, April I9, $\mathrm{I}_{763}$. 


\section{L'Enfant Terrible}

he adds, "he will find difficulty in uncaterpillaring himself." 1 In his next letter, he is somewhat more hopeful, remarking, "I do not believe that the eldest is as bad a subject as they would have me fear, but" -still pessimistic-"the absolute platitude and the quality of caterpillar, oh yes." 2 He concludes this letter with the remark that "the eldest was made to be led in the beaten path." 3

At this time, the marquis was desirous of intrusting the young son, Boniface, to his uncle. After speaking in the most enthusiastic manner of the good qualities of the boy, he concluded, "I would then have upon my shoulders only the eldest, and I assure you that it is quite sufficient, either as regards the kind or the expense." 4 Although he complains of the expenseand in the future this complaint will be one of frequent recurrence-he does not abandon the attempt to make something of his son by educating him. In November, he writes of his intention of sending him to the academy of Angers, a famous school of that day, "to remove him from the degradation of Paris." 5 This plan was not carried out, but the following year he was sent to Versailles and placed in charge of a $\mathrm{M}$. Sigrais, a friend of the marquis. The reason for this action is explained in a letter to the bailli:

I had no longer any need of Poisson. My son had out-

1 Correspondance générale, iv., 329. The marquis to the bailli, Bignon, July $19, x_{7} 63$.

2 Ibid., iv., 334. The marquis to the bailli, Bignon, August I 3 , I 763 .

3 Ibid.

4bid., iv., 357. The marquis to the bailli, Paris, October I6, I763.

5 Ibid., iv., 367 . The marquis to the bailli, Paris, November 20 , I 763 .

vor. I-ro 
grown him and he had not been equal to his task. The eldest, up to the present time, is what he promised to be, that is all there is to be said. He is the one of my children that has caused me the most perplexity and to whom I have given the most attention, that I might have no cause to reproach myself. We can neither hold him nor let him go [the father exclaimed in despair]. He fears me and he fears only me. I shall employ for him to the very end the influence that Providence has given me in the world. In the midst of my perplexities, I fixed upon a middle course, and induced the honest Sigrais, whom you know, to take charge of him during the time that may be necessary to settle the question and to form a transition from the paternal mansion to the freedom of the army. I shall turn him over to him only at the time that he leaves for the country, that he may not be overcrowded in his little apartment at Versailles. Now he is working at his geometry and the most of the time under lock and key.'

With the year $\mathrm{I}_{764}$, the boyhood of Mirabeau came to an end. Up to this time, he had been educated under the eye of his father either at Bignon or at Paris. While Poisson was his governor, he had had many teachers and masters. As far as can be judged from the evidence, his father had spared neither pains nor expense to make the boy's education as complete as possible. Intellectually much had been accomplished, but evidently neither the marquis nor Poisson was capable of presiding successfully at the unfolding of this precocious mind, of directing aright the growth of the child's moral nature. 2 That the moral training

1 Correspondance générale, iv., 373. The marquis to the bailli, Paris, January I $5, I_{764}$.

2 While at Vincennes, Mirabeau wrote to Sophie de Monnier: “Je te dirai qu' une des grosses injures que mon père me disait dans ma jeunesse, c'est que j'étais ou serais un Cardinal de Retz. 


\section{L'Enfant Terrible}

did not produce better results, was due not alone to the teachers; neither inherited tendencies nor home surroundings were of a nature to reinforce the training that the child received. I have already considered the hereditary influences that made Mirabeau "a child born under an evil star"; it is necessary to examine the domestic environment in which he grew up.

Certes il me faisait trop d'honneur; car c'etait un grand et au fond un honnête homme."-Lettres originales de Mirabeau, iv., I०3. 


\section{CHAPTER VIII}

\section{AN UNHAPPY FAMILY}

LOUIS DE LOMÉNIE characterises the Mira-
beaus as "one of the stormiest families of the
eighteenth century." While this characterisation is strictly accurate when applied to the history of the family between the years I770 and I789, it is not just to the period between the marriage of the marquis in $I 743$ and his virtual separation from his wife in $I 762$. For our present purpose, it is the latter period that concerns us. Here to a very large extent, in the past, chronology has been disregarded and evidence has been used without any visible effort to determine its probable value. The patient industry and the calm, unprejudiced judgment of M. de Loménie corrected all this and enable us to construct a much more reliable picture of the family life of which young Mirabeau formed a part. ${ }^{1}$

The influence of the family life upon the boy from his birth in I749 until his departure from home in February, I764, will be more intelligible if this life be looked upon as passing through three phases. In

1 For the material for this chapter, I have drawn heavily upon the works of M. Louis de Loménie, La Comtesse de Rochefort et ses amis (76-216) and Les Mirabeaux [i.. 414-437 ii., 22 7-242, 435-559], that contain a large number of letters of the marquis and some of Madame de Pailly. When the source of my information is not indicated it will be understood to be one of these works. 


\section{An Unhappy Family}

the first ( $\left.1749^{-1} 75^{6}\right)$, there are no indications of serious disagreements between the father and mother, the marquis treating his wife with consideration; in the second ( $175^{6-1762)}$, there are visible signs of discontent, ending in an actual, but not legal, separation; lastly, in the third period, consisting of two years, the mother is absent and a stranger fills her place in the household. A simple enumeration of these periods is sufficient to make clear that the influence of the environment was not uniform and cannot be characterised as well as it can be described.

The character of the young Marquise de Mirabeau has been treated in a previous chapter. The marriage that united her to the marquis had been a purely business transaction. With her youth, her unfortunate character, and her "pestilential and impudent education," the probabilities that she would prove an attractive companion for her husband were exceedingly small. That they lived together for nearly twenty years without any serious misunderstandings is an interesting fact and one upon which not sufficient emphasis has been laid. The wife-of whom the bailli said in later years that since the creation of the world no one had seen a wife like the one that God had given the marquis-was disliked both by the bailli and by the mother of the marquis. ${ }^{1}$ She was passionately attached to her husband and, although the abandon and childishness with which she displayed her

1"Cette erreur [his marriage], qui fut si fatale pour lui, eut pour première conséquence de le placer entre une mère austère, pieuse, méthodique jusqu'à exces, et une femme foncièrement extravagante, denuée de tenue en tous genres, toutes deux antipathiques l'une à l'autre, et vivant presque toujours, pendant bien des années, sous le même toit."-Loménie, i., I I4. 
affection must have been distasteful to him, ${ }^{1}$ although he was not ignorant of the feelings of his brother and mother, he kept his own counsel, shielded his wife to the utmost of his ability, and evidently tried to make the best of a bad bargain. If he was not in truth attached to her, he gave all the outward signs of attachment and appeared to others to be blind to her defects. $^{2}$ These are the facts; the explanation of them would be largely a matter of conjecture. The motives that were responsible for the marriage were still operative after the marriage. The formation of a large family estate and the perpetuation of the family name were possible only on the condition that the marquis and his wife lived together in harmony. That in the first years of their married life he was not entirely without affection for his wife is not improbable. ${ }^{3} \mathrm{Un}$ doubtedly the consideration that he showed her in the early years was also due to the hearty support that she gave to the execution of his plans. "My wife and I," wrote the marquis in 1747 , four years after his marriage, "have undertaken much, but we have not dissipated anything. My wife has never had a childhood in this matter. Assuredly we have led

1"Au reste tellement conjugale à sa mode qu'il était impossible à son mari de s'écarter de deux lieues sans avoir des scènes de pleurs et de négotiations consolatrices, parceque cet homme, peu sage et sans prévoyance, n'avait pas eu la précaution de rompre cela de bonne heure."-Letter of the marquis to Madame du Saillant, his daughter, written in June, I 776. Loménie, ii., 453.

2 "A qui as-tu cru avoir caché les défauts et les vices de ta femme? Tu ne me les as pas cachés huit jours, au moins en partie, ma mère de même. Toi seul tu te cachais, et parceque tu la soutenais, dis-tu, pour qu'on ne la foulât pas aux pieds, tu croyais nous avoir convaincus." -The bailli to the marquis, February, 1783 . Loménie, ii., 44r.

${ }^{3}$ Loménie, ii., 457. 


\section{An Unhappy Family}

a life proper to fit us for many hardships and details." The young wife interested herself in all her husband's plans, even taking part against her own parents. In a letter written in I749, announcing the birth of Mirabeau, the marquis praised the charitable acts of his wife, who cared for the suffering peasants of Bignon, "bandaging with a courage de temperament the most hideous ulcers." In spite of the unconcealed dislike of the bailli for the marquise, she was kindly disposed toward him and endeavoured to acquire his good will. On one occasion, in 1756 , when the marquise wished to make him a present, the bailli, suspecting falsely that the idea had been suggested by her husband, who was desirous of rendering him more indulgent, refused the present. "I have been shocked," he wrote to his brother, "to see that you have not felt that, in spite of the imperfections of your wife, her position as mother of a family would render her dear to me, and sufficiently so that you need not call down upon me these little pranks of hers." The marquis protested that he had had nothing to do with the matter. "I owe her an explanation as a matter of justice in this affair; as you do not like to receive and as, furthermore, she is gauche, I have often restrained her, and never urged her on." In conclusion, he assured the bailli, referring with a shade of irony to the Limousin accent of his wife, that she "always spoke very kindly of the chevalier, mon fraire."

Before the end of the first period had been reached, evidence was not lacking that the marquis looked upon his married life as a duty to be performed rather than as a pleasure to be enjoyed.

You are wrong when you say that I do not love you 
[he wrote to his wife in $175^{2}$ ]; I am very much attached to you, both from duty and because you have need of it, and as a return for the kind of turbulent attachment with which you have maddened me for ten years; and if I did not love you, you would be insupportable to me.

When, in 1756 , he invited the bailli to become a member of his household, he referred apologetically to "the little domestic annoyances that are to be met with everywhere and such as torment me at times, while they spare you." 1 Not before $175^{8}$ do we find any indication of a desire on the part of the marquis to separate from his wife or any trace of domestic infelicity that might serve as a sign of impending evil. The family life of the Mirabeaus during this period was not ideal, but it differed little from the lives of other families in this country of the mariage de convenance.

The first ten years of the life of young Mirabeau were clearly not rendered unhappy by the quarrels of his parents. The environment was not, however, favourable to the happy development of such a character, as his grandmother disliked both the boy and his mother; the influence of the mother must have been evil rather than good, strengthening the unfortunate tendencies in the boy's character and undermining the good work of Poisson. All this is, of course, mere inference, no direct evidence existing upon the relations between the boy and his mother at this time. It has already been pointed out that, while the attitude of the father toward the son was unsympathetic, he was labouring in his pedantic way to make a man of him.

Although the marquis had not been a model of virtue during this first period of his married life, his diversions

1Loménie, ii., 449. 


\section{An Unhappy Family}

had not been of a nature to produce serious trouble between himself and his wife. As long as the proprieties were not violated and scandals were avoided, infidelity to the marriage vow was not looked upon as an unpardonable sin by the society in which the marquis moved. In I 755, however, is to be found the beginning of his relations with Madame de Pailly, 1 a woman who in the last thirty years of his life was to occupy a place in his affections and in his home that his lawful wife had never occupied. Madame de Pailly was no vulgar adventuress, nor was her liaison with the Marquis de Mirabeau only another one of those passing fancies, that, soon outworn, left no lasting trace behind. It was the one serious love affair of his life.

Madame de Pailly was born in Switzerland and was probably educated in France. Her husband, a Swiss officer in the French service, was thirty years her senior. He lived at Lausanne with his sisters. Madame de Pailly passed the most of her time in France, visiting her husband at irregular intervals. At the time that the marquis met her, she was a charming woman of about thirty years. Somewhat inclined to embonpoint, she wisely attired herself in black, thereby enhancing the dazzling whiteness of her skin. She was "full of sentiment and grace," "seductive and distinguished." She was a favourite in the salon of

1"A quelle époque Mme. de Pailly connut-elle le marquis de Mirabeau? Dans une lettre à la Comtesse de Rochefort, datée de $I_{9}$ juillet $\mathrm{I}_{762}$, il dit au sujet de son amie: 'Il y a sept ans que je recois d'elle des lettres'; ce que ferait remonter leurs relations

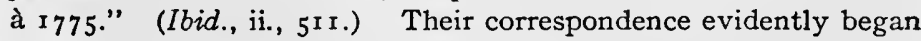
in 1775 , when Mirabeau was six years old, but is it not probable that the marquis had known Madame de Pailly some time before the correspondence began? 
Madame de Rochefort at the Luxembourg, and "among the members of the family in which she exercised an influence that did not naturally belong to her, there was not one, not even excepting Mirabeau himself, often unjust toward her, who did not at times, and very sincerely, recognise in her noble and attractive qualities." The bailli, not the most friendly of judges, "discerned in her a mind as just and as acute as was ever born on the Helvetian hills." 1 The favour of such a woman, the very antithesis of the wife who had been called "one of the most ridiculous creatures in the world," 2 could not fail to render intolerable to the marquis the presence in his home of the woman who bore his name and who was the mother of his children.

At the death of M. de Vassan, in $175^{6}$, the family history passed into the second phase. The marquis now entered upon a portion of the inheritance for which he had waited thirteen years; but, as Madame de Vassan held the most of the property in her own name, it was but a small part of the estate that now fell into his hands. The larger portion was to remain for some years yet in the hands of his mother-in-law. In this increase in the revenues of the household, $M$. de Loménie sees a cause of discord that was soon to render husband and wife irreconcilable. Much emphasis, I am inclined to believe, should also be laid upon the increasing intimacy with Madame de Pailly. The friendship ripened rapidly, for in 1757 the relations were certainly confidential and the marquis was evi-

1 Loménie, ii., 508.

2 Ibid., ii., 443. The bailli wrote to the marquis in $r 780$ that at the time of his marriage these words were frequently used in speaking of the marquise. 


\section{An Unhappy Family}

dently endeavouring to win for her the good will of the bailli, who was already acquainted with her. ${ }^{1}$ It is highly probable that the fondness of the marquis for the "belle Bernese" contributed somewhat to bring about the strained relations between him and his wife in $175^{8}$. It was not the chief cause. That was seemingly found in the infidelity of the marquis and in the jealousy of his wife. ${ }^{2}$ The marquis took advantage of the opportunity to suggest a settlement that would permit each one to go his own way.

Even if your home displeases you so much [he wrote to his wife] I cannot leave it as long as my mother lives; but for that, you would be the mistress of it, to ruin it entirely and to manage it to suit your fancy; I would pay my board there and live as a bachelor elsewhere; 3 but as long as my mother lives, I must sustain her and assist her. You ought to think the same as regards your own; and not being able to suffer you here, I would leave you free

1 "Je ferai passer ta lettre de change en Hollande par le voye de Mme. de Pailly qui a ce qu'il faut pour cela et me l'offrit."-Correspondance générale, ii., 3 Ir. The marquis to the chevalier, Paris, August 4 , I 757. "N'oublie pas l'affaire de Mme. de Pailly; ton ministre a maintenant remis les papiers de contrôle; sacher de lui s'il a songé à ce qu'il a promis à ce sujet. Tu as montré trop de chaleur première pour l'abandonner."-Ibid., ii., 349. The marquis to the chevalier, Paris, September I9, I 757 .

2 The domestic troubles of the marquis were not unknown to his friends. Madame de Rochefort wrote to him in 1757 : "Vous ne sentiriez pas les contraintes et les contrariétés, si vous étiez facile. Vous vous y soumettez parceque vous êtes bon, et votre soumission vous fait croire que vous êtes souple, tandis qu'elle apprend seulement que vous n'êtes pas heureux."-Loménie, La Comtesse de Rochefort et ses amis, 87 .

${ }^{3}$ In connection with this statement it is interesting to recall the reasoning of the marquis at the time of his marriage. If he did not find the society of his wife and of his mother-in-law agreeable, he counted at that time on leaving them in Limousin, "with their 4000 livres, and I would live as a bachelor." See Chapter V. 
to live with her or to live by yourself; I would return your property to you; you would contribute something to the support and education of our children and that could be done by agreement and without scandal. If that is what you want, I will agree to it at once by a contract made and duly sealed in the presence of $M$. Desjobert; if not, endeavour to remain quiet in your home, study my tastes a little, and I will study yours, for in the long run the practice of forcing everything accomplishes nothing. I am the Ami des hommes, and the conscience of my wife is the best witness of it. I appeal to it in this matter, for pleadings are of little value. Finally, Cato sent his wife away; and when they asked for the ifs and the buts he showed his shoe: "It is well made," he said, "and yet it hurts me, and no one of you can tell me where." I shall not send mine away, but if she sends me away I shall consider myself sent away forever, and you can count upon my word of honour. ${ }^{1}$

The language is frank to the point of brutality; there was no possibility of misunderstanding it. The wife was still attached to the husband, but she had become insufferable to him. She complained of his infidelity, while he claimed the right to go his own way, permitting her to go hers. He makes no definite charges against her; "the shoe is well made, but it hurts me." Finally, he would not send her awayapparently he has no grounds for such action-but if she would not let him alone, would not "study his

1 Loménie, ii., 458, 459. The letter was written July I 5, I758. It was published by the marquise during the lawsuit with her husband. The opening sentences contain the complaints of the marquis; the marquis then adds: "Vous dites que je me suis sépare de vous; j'ai cru que vous pensiez tout comme moi, qu' après onze enfants on pouvait s'arrôter. . . . Vous demandez le renvoi d'une fille qui est depuis huit ans dans la maison, parcequ'elle vous a manque . . . Vous m'en faites parler par des tiers; j'accorde la chose, et vous voulez que je la jette dehors." 


\section{An Unhappy Family}

tastes a little," if she should send him away, he would never return.

She did not send him away and for four years more they continued to live under the same roof. Between his mother and his wife, the mediation of the marquis was more indispensable than ever. "You know," he wrote to the bailli in 1758 , "that without me, those women could not live together a week." 1 In his letters to his brother, the name of Madame de Pailly recurs more frequently than that of his wife. ${ }^{2}$ Each year she was evidently becoming a more important factor in his life.

It is possible that the arrest and exile of the marquis in 1760 delayed the dénouement that seemed imminent in 758 . The marquise won at least a passing comment from her husband because of her efforts to effect his release from Vincennes. ${ }^{3}$ At the same time the marquis was becoming more enamoured of Madame de Pailly. In later years, referring to his imprisonment, he said that he took with him to prison the "Meditations of Marcus Aurelius by the advice of a friend beautiful

1 Correspondance générale, ii., 469.

"Mme. de Pailly me charge aussi de te dire bien de choses de sa part."-Ibid., iii., 229. The marquis to the chevalier, Paris, July I5, I 760. "Mme de Pailly en a fait la mine par ce qu'elle sent bien que je perdrai mon bras droit, mais après les raisons de dindes elle dit il faut donc que j'en sois bien aise."-Ibid., iii., 242. The marquis to the chevalier, Paris, July 29, I760. "Je dine aujourd'hui chez Mme. de Pailly avec les La Roque qui y sont venus exprès. C'est te dire qu'on y boira de bon coeur à ta santé."-Ibid., iii., 25 I. The marquis to the chevalier, Paris, August 20, I760.

3 "J'ai fait courir ma femme; mais je l'ai attendue de peur qu'elle ne s'essouflât, et sa conduite à mon égard lui a fait honneur." -Loménie, La Comtesse de Rochefort et ses amis, 1 06, a letter of the marquis to Madame de Rochefort of December 28, 1760 . A reference to Madame de Mirabeau is found in a letter of Madame de Rochefort addressed to the marquis December 27, I 760 : "Je n'ai pas eu l'honneur de voir Mme. de Mirabeau, quoique j'ai été la 
as the day." 1 She shared the first month of his exile at Bignon, and as long as she remained he was as happy as a young lover. Although it was January, he described for the edification of his friends at Paris the charms of his country seat and above all of his company.2 At this time, Madame de Rochefort had never met Madame de Pailly, and she learned that the exile of the marquis was shared by a " lady friend," "one of the persons of her sex who does it the greatest honour by the breadth, the solidity of her mind and by the goodness of her heart. Unfortunately we are threatened with losing her, as her husband is about to return from the army." 3 To the bailli, he wrote of the "great proofs of friendship given both to Madame de Mirabeau and to himself by Madame de Pailly," "whose excellent disposition is as pleasing to Madame de Mirabeau as to myself." " The marquis never failed to send some flattering message to his brother from Madame de Pailly, who charged him to tell the bailli "all that she thinks of him, and as you know," added the marquis, "it is not a little."'s The good bailli received all these advances coldly, re-

chercher pendant votre prison. Si je pouvais lui être bonne à quelque chose pendant votre absence, je m'estimerais fort heureuse et je suis bien st̂re que ce serait un moyen de vous plaire."-Ibid., ro3.

1 Loménie, ii., $5^{1} 5$, in a letter written to the Marquis Longo.

3 "Les eaux, les près et les petits bois dont elle est entourée ne sont pas, il est vrai, de saison comme en mai; mais quand le calme règne, l'imagination leur prête plus que la réalité ne leur ôte. Les promenades sont sèches, toutes les communications entre les hamaux sont en pelouse."-Ibid., ii, 230.

"Ibid., ii., 230, 231.

- Correspondance generale, iii., 392. The marquis to the chevalier, Bignon, January ro, r $76 r$.

5 Ibid., iii., 388 (Jan. 9, I 76I), 392 (Jan. Io, I76I), 394 (Jan. I6, I76I), 402 (Jan. 24, I 76I), 4II (Feb. 3, I76I). In this same letter is found a bit of information upon the relation of the marquis to 


\section{An Unhappy Family}

questing his brother to "say to Madame de Pailly that she should not think so many good things of him, as he did not deserve it." 1 At times he made no reply. ${ }^{2}$

When, early in February, Madame de Pailly, " having fulfilled toward us [the marquis and his wife] the duties of the most essential and the most obliging friendship," ${ }^{3}$ returned to Paris, escorted by her husband the marquis had already decided that life at Bignon, without her and tête-d̀-tête with his wife, would be intolerable. Madame de Pailly was charged with a letter to be delivered personally to the King's favourite, Madame de Pompadour; she was also to explain in full to the bailli the plan that had been formed for the release of the marquis. "You may depend upon what Madame de Pailly tells you concerning our health, our feelings, etc.," wrote the marquis to his brother. "Long ago you made up your mind about this woman, but you should see her in a limited circle with people difficult to get on with [his wife, doubtless] in order to know what she is." 4 He would not allow them

the father of Madame de Pailly: "Au reste," wrote the marquis to the bailli, "je te prie quand il arrivera ou dinde ou chaperons \&c., d'en faire passer de temps en temps à son père. C'est une petite attention qu'ils meritent bien par la leur de se priver pour nous de leur fille et soeur. J'aurais voulu lui faire passer une douzaine de bouteilles de mon vin de Languedoc, dont je sais qu'il fait cas, mais Garçon m'a dit qu'il n'en restait plus que quelques demi-bouteilles et une pièce non tirée."

1 Correspondance generrale, iii., 397. The chevalier to the marquis, Paris, January 21, I76r. Also iii., 394 (Jan. ro, I76r), and 408 (Jan. $27, \mathrm{I} 76 \mathrm{I})$.

2 "Mme. de Pailly, auprès de laquelle, j'ai supplié à ton silence, te dit mille choses."-Ibid., iii., 404. The marquis to the chevalier, Bignon, January 27 , I 761 .

${ }^{3}$ Ibid., iii., 4 I I. The marquis to the chevalier, Bignon, February 6, I761.

4 Ibid. 
"to make him shiver any longer at Bignon." His mother, who was ill in Paris, must write to the minister Saint-Florentin demanding the presence of her son. He himself would write to Madame de Pompadour or to the minister to give notice that he asked to be tried in due form, or that he be left free to make use of his natural rights as a son and to fulfil his duties, adding that he "would appeal in this matter to the parliament and to the public, and if a deaf ear was turned to his requests, he would, if necessary, go to Paris without permission." 1

The change was a very abrupt one and the explanation did not escape the bailli. "I know very well," he wrote to the impatient lover posing as a faithful son, "that you have particular reasons for not being pleased with your present situation" 2 (alone with his wife). However, both the bailli and his mother opposed the plan, the mother writing an old-time letter expressing her disapproval of his course. The son submitted. 3 His exile was prolonged until the 2 Ist of February, when, through the efforts of the bailli and of Madame de Pailly, the marquis was allowed to come to Paris to see his mother, and the exile was at an end. 4

1 Loménie, ii., 237.

2 Ibid., ii., 240.

3 The letter of the mother and the answer are found in Loménie, i., II2, II3.

- Loménie, ii., 24I. "Mme. de Pailly a de plus remis à la maison où je n'étais pas lorsqu'elle est venue, ta lettre du 6. Elle y a laissé aussi la copie de la lettre dont tu l'as chargée pour Mme. de Pompadour."-Correspondance générale, iii., 4r3. The chevalier to the marquis, Paris, February 9, I76r. "Depuis ma lettre écrite, j'ai été voir Mme. de Pailly que j'ai trouvée de même avis que vous." Ibid. The marquis was not pleased at the manner in which the chevalier treated his fair ambassadress: "Je vois, cher frère, par la subite arrivée du St. Blanchet, que tu ne t'es donné la peine d'in- 
The marquis was a devoted son, but he was also an ardent lover, cloaking his love under the name of friendship. It was, perhaps, fortunate for him that there was no conflict in the two rôles. He returned to Paris and to Madame de Pailly. ${ }^{1}$ His mother was ill at Passy, and like a dutiful son he visited her every other day, ${ }^{2}$ but we learn from a letter to the bailli that Madame de Pailly "has been with my mother at Passy ever since she has been alone there, . . . kindly and graciously keeping her company." 3 The nicety with which this Frenchman of the eighteenth century observed the proprieties while pursuing his love affairs fills one with respect for his virtuosity. The marquis continued to woo the favour of his brother for Madame de Pailly, but with no success. The bailli made a cold return to all her friendly advances. ${ }^{4}$

The marquis was more successful in another direction. When Madame de Pailly returned to Paris in February, I $76 \mathrm{I}$, she carried a letter of introduction from him to his friend Madame de Rochefort. Both had apartments in the Luxembourg. The acquaintance at once ripened into friendship. "Every day I am fonder of

terroger Mme. de Pailly sur ma situation d'esprit et de cœur."Ibid., iii., 42r. The marquis to the chevalier, Bignon, February II, I $76 \mathrm{r}$.

1"Mme. de Pailly ne t'oublie point."-Ibid., iii., 457. The marquis to the chevalier, Paris, April 23, 176r.

2 Ibid., iii., 493. The marquis to the chevalier, Paris, June I, I $76 \mathrm{r}$.

3 Ibid., iii., 497. The marquis to the chevalier, Paris, June 8, I 76r. Also, iii., 50r. The marquis to the chevalier, Paris, June I2, I76r.

4"Je suis sensible au souvenir de Mme. de Pailly; mais je ne trouve pas qu'elle soit connoisseuse. J'ai beau me tâter, je ne trouve pas que je merite à beaucoup près l'idée qu'elle a de moi. Je l'en remercie cependant."-Ibid., 5ro. The chevalier to the marquis, Toulon, June 16 , I76r.

vol. I-II 
my neighbour," wrote Madame de Rochefort to the marquis in 1762 , "my relations with her unfolding to me each day more and more the treasures of her heart." 1

With the year 1762 came the crisis in the relations between the marquis and his wife. It will be remembered that the marquis had assured his wife in $175^{8}$ that he would never send her away. He did not, but when she went away to Limousin in this fatal year to visit her mother, who was sick, he asked her not to return. The marquise was evidently unconscious of the designs of her husband. She even wrote an affectionate letter to him urging him to come to her, assuring him that he "would be dear to her, whatever might happen, to the last hour of her life." Some months later he did go to her, to propose that in the future they would live apart. The negotiations were not successful. During his absence, Madame de Pailly was at Bignon visiting his mother. ${ }^{2}$

It was the close of the year I 762 , or at the beginning of the next year, that the mysterious papers that were to be used so skilfully against his wife fell into the hands of the marquis. How many there were and what they contained is known only by hearsay. They were never made public; none of the biographers of the Mirabeau family ever saw them, and it is not known how many of the persons directly concerned ever set their eyes upon the documents to whose contents

- Loménie, La Comtesse de Rochefort et ses amis, I 59.

2 Loménie, ii., 460-462. In I762, Madame de Rochefort wrote to the marquis as follows: "Je ne suis plus en peine de ma voisine. Elle est à la campagne. Elle jouit de la douceur d'être avec votre digne mère. Elles se font du bien reciproquement en pensant à celui que cette idee vous doit faire."-Loménie, La Comtesse de Rochefort et ses amis, I 59 . 


\section{An Unhappy Family}

they made frequent reference. It is certain that both the bailli, his nephew, Madame de Pailly, and Madame de Rochefort knew of their contents and may have seen them. They were of the most compromising character, but how they happened to be written and just what their significance was has never been made clear and probably never will be. The marquise herself did not deny the genuineness of the documents, but treated the whole matter lightly, declaring that it was merely a joke. Whatever interpretation may be given to it, the papers cannot be overlooked in forming an estimate of the character of the mother of Mirabeau. Armed with these documents, the marquis was in a position to dictate terms to his wife. ${ }^{1}$

The marquise had announced her intention of coming to Paris. The marquis advised her not to come, insinuating that he had means of preventing her. When she continued to insist, he left her letters unanswered. At length the evil report that the marquis circulated concerning her reached her ears. She at once wrote to her husband a long and incoherent letter, expressing her willingness to make the arrangements that he had so long desired. The larger part of the letter has been published by M. Louis de Loménie. ${ }^{2}$ It is certainly a revelation of character, but to my mind contains little evidence that is convincing concerning the guilt or innocence of the mother of Mirabeau. She complains that the marquis does not deign to answer her concerning the journey to Paris. Her honour demands that she go there on account of the rumours and slanders that are in circulation concerning her conduct. "Others would regard her conduct as it really was -facility and a good heart." After referring to the

1 Loménie. ii., 462-465.

2 Loménie, ii., 467-470. 
threats made against her, threats that reached her indirectly, without circumlocution she came directly to the question at issue. "State your griefs, sir, make the most of them," she exclaimed. "I will state mine in reply, and if I have done wrong, my sins have all emanated from yours. The manner in which you have treated me has turned my heart against you; it is lacerated and it will never be healed. You wish me to remain here. Very well, I agree to do so." She demanded an allowance of 2000 écus, payable quarterly: If the marquis agreed to this, she promised to remain in Limousin and never go to Paris again; if he did not, she would set out the first of April.

"I believe," she continued, "that I ask only what I need and that something will remain for the support of my children, to which I desire to contribute. It has not been wished that it should be by my cares. I am not capable of it. It has been judged that strangers were more worthy of it. I hope for the good of the cause that it may succeed." The letter closed with a passage in which business crowds upon sentiment, almost turning the reader's pity into amusement: "Perhaps," she wrote,

in my absence, in time you will love me more and render me the justice that is due me in all things. For myself, I shall always have the sentiments that I ought to have for the father of my children and I shall ever inspire in them when I see them only respect and love for him. I shall regard them as monsters, if they fail there. You can easily imagine, sir, that the six thousand francs I content myself with yearly will be only for the time during which I shall be fortunate enough to have mamma; this allowance, if I should have the misfortune to lose her, would not be enough to keep up an establishment. 


\section{An Unhappy Family}

It is, indeed, a distressing letter. It could not be otherwise; it is one of the documents of a great family tragedy. The affair is as compiex as life itself. This woman, a wife at seventeen, the mother of eleven children, cast off after nearly twenty years of married life, challenges sympathy. She was a strange creature, with little education before marriage and little opportunity and inclination to procure one after marriage. The irregularities of the marquis before his marriage are a matter of evidence; in the light of his earlier life, the charges of unfaithfulness made by his wife must be accepted as highly probable. ${ }^{1}$ She then stated the simple fact when she exclaimed "My sins emanated from yours." She followed a bad example, and she doubtless followed it with all the abandon of her uncontrolled impulses. She was still attached to her husband, when her presence had become insufferable to him. He carried his burden for twenty years and there can be little doubt that he suffered. She meant well, but she was truly an impossible creature, unattractive personally, no companion to her husband, standing in the way of his advancement, and unable to maintain a well-regulated household. At length the marquis met the woman who was to be to him all that his wife had not been and could not be. For eight years he still continued to live with his wife, and then he cast her off. Her affection for him was to turn to hatred and this hatred he was to return with full measure. They were the victims of the mariage de convenance.

The marquis accepted the terms proposed by his

1 See in Lettres originales de Mirabeau (iv., 56) the report by Mirabeau of the language used by his mother in I 770 in referring to her relations with her husband. 
wife, paying the allowance monthly instead of quarterly as she had requested. In August of the same year, ${ }_{17} 6_{3}$, he entered into a written agreement to increase the allowance of his wife, on the death of her mother, from six thousand to ten thousand livres. The affair seemed to be settled in a manner satisfactory to both parties.

Five hundred livres a month were not, however, sufficient for the pleasures of the marquise. She was passionately fond of play. Not only was her allowance consumed in advance, but she contracted debts. As the creditors addressed themselves to the marquis, he undertook to meet their demands by withholding a portion of the monthly allowance. The indignation of the marquise was great. At this time, she was living as a boarder in a convent in Limoges. Her mother had taken up her residence with her granddaughter, Madame du Saillant, and although the marquise was embroiled both with her son-in-law and her daughter, she was attempting to force them to accept her as an unwelcome guest in their chateau. In addition to all this, it was reported to the marquis that the relations of his wife with a certain garde $d u$ corps in the Limousin were of a compromising character. "All of these motives determined the marquis to have recourse for the first time in his life to a dangerous weapon, in the use of which he was soon to be guilty of the strangest abuse, to the detriment of his own repose and popularity." In I766, he obtained from Minister Bertin a lettre de cachet against his wife confining her to the convent in which she had been a free lodger up to that time.

The lettres de cachet, one of the most typical institutions of old French society, have been aptly called 


\section{An Unhappy Family}

"the very essence of public life" before the revolution. Upon them rested the authority of the king and the honour of the family; for, in the last resort, the king had no other means of enforcing his will throughout the realm, and the family relied upon these arbitrary orders to protect itself against degenerate members. It is commonly believed that the employment of lettres de cachet was largely confined to affairs of state and used by the noble against the roturier, yet this is far from the truth. The evidence shows conclusively that out of a thousand cases but four or five were of a political character, while the remaining nine hundred and ninety-five or-six dealt with matters of police or of family. In all of these latter cases, the initiative was taken by the family, the government simply responding to the demands made upon it, demands multitudinous in number, varied in character, and not confined to any rank or class. ${ }^{1}$

Unfortunately, the abuses of this institution outweighed the benefits that flowed from it, and it had long since been condemned by reformers as illegal and iniquitous. The marquis in employing the lettre de cachet to settle his domestic troubles knowingly sinned against his principles and did violence to his conscience. Some years before, at the request of his agent who administered the estate of Mirabeau, he sought to obtain from the government lettres de cachet against two disreputable characters of the commune; he was unsuccessful. He regretted having made the request and declared that he would never do it again. Courts existed for all cases, and although they had their defects, it is better, he believed, to suffer from these than to interfere with the course of justice. He

1 Revue des deux mondes, October, 1892, pp. 821-854. 
advised his descendants never to have recourse to a lettre de cachet, however good their particular reasons might be, because of the abuses that resulted from its employment.

In appealing to the lettre de cachet in his troubles with his wife, the marquis was not only guilty of violating justice by acting as judge in his own case: he was also imprudent in his endeavour to frighten rather than to conciliate the marquise, as he had reason to fear more than she the scandal and the effects of a trial for divorce and for separation of the property held in common.

The marquise proved to be a most unruly prisoner and rendered almost intolerable the life of the mother superior of the Abbaye des Alloix, where she was confined. In a letter to the marquis, in which she described the outbreaks of the marquise, Madame de Lentilhac conjured him to relieve her of the great burden. If he delayed action too long she would be obliged to appeal to the minister. The action of the marquis was undoubtedly hastened by this protest. On the $3 \mathrm{~d}$ of July, I766, a compromise, drawn up by Bertin, was laid before the prisoner. The terms were accepted by the marquise and governed her relations with her husband until the death of her mother in 1770 . She agreed to live as a boarder in some convent that she should choose herself in Limoges, promising not to leave the city without having previously informed the marquis and obtained his consent; he promised to ask for the revocation of the lettre de cachet and to pay to his wife the allowance of five hundred livres without reservation. Three copies of the agreement were made, one being left in the hands of the minister M. SaintFlorentin to nullify all appeals to arbitrary orders as 
long as the agreement lasted. On August first, the lettre de cachet was revoked.

The situation of young Mirabeau was not improved by the absence of his mother. Her place was taken by Madame de Pailly, who now identified her interests more closely than ever with those of the marquis. The conventionalities were, however, still observed. The head of the household after the departure of the marquise was the mother of the marquis, assisted by the young widow of Louis Alexandre. After the death of the young sister-in-law and the mental derangement of his mother, followed shortly by her death, Madame du Saillant, the eldest daughter of the marquis, cared for his household. Although Madame de Pailly did not reside with the marquis at Paris, she did not hesitate to preside over some of the famous economic dinners given by him in the interest of the sect. 1

She was naturally a partisan of the marquis in the troubles with his wife and gave him not a little valuable assistance. Madame de Rochefort was the friend of the Duc de Nivernois and the duke was very influential at court. Madame de Pailly skilfully played upon the feelings of her friend, strengthening her prejudices against the wife and arousing and strengthening her sympathies for the unfortunate husband. She dwelt

1 "M. le Marquis de Mirabeau a établi un dîner tous les mardis auquel sont invités de droit tous les amateurs de la science. J'ai eu l'honneur d'y être admis pendant mon séjour et l'on me mande que les plus grands seigneurs du royaume s'empressent aujourd'hui d'y venir puiser des lumières. Mme. de Pailly, femme d'un colonel de votre pays, s'y trouve régulièrement. Peut-être la connaissezvous. C'est une femme vraiement philosophe et qui joint tous les agréments de son sexe à la profondeur et à la solidité de l'esprit." -Letter of Trosne, Orleans, August 22, I767. Published by Oncken, 75 . 
upon the virtues of the marquis and the vices of his wife. "It should be known," she wrote in ${ }^{7} 6_{3}$ during the first negotiations, "how he has sown pearls before swine, or, to speak more correctly, his goodness and virtue should be known as well as the madness and the atrocious injustice of the people with whom he has to do." She feared that no agreement would be reached and that "this poor man will be condemned all his life to the cruel occupation of holding this mad creature in control." She referred to the marquise and her mother as "those heterogeneous beings" and "those fools." After painting a picture of the financial situation of the marquis, Madame de Pailly concluded: "That is the condition of the fortune of this fine heiress of a million; there will remain to him as net gain five children, not one of whom resembles him except the poor little chevalier." Madame de Rochefort was completely won over to the cause of the marquis. It is evident from her letters that she had little sympathy for his "eternal mother-in-law" and that she believed that her friend "had no real cross but his wife and that he would have a hard time in getting rid of her."

The affection of Madame de Pailly for the marquis was certainly disinterested. Although she possessed but a small fortune, in $I_{7} 6_{3}$, when the bailli became general of the galleys of Malta, she loaned twenty thousand francs to the marquis to enable his brother to meet the expenses of the office. This loan was afterwards increased to forty-two thousand francs. Madame de Pailly never pressed her claim, allowing other creditors to take precedence of her, and when the marquis died in $\mathrm{I}_{7} 89$ the debt was still unpaid. She never recovered her loan.

Madame de Pailly was a Protestant and Swiss, and 


\section{An Unhappy Family}

she was seemingly disturbed not a little by her conscience, realising that she was not fulfilling her duties toward her husband and somewhat concerned over "what would be said about it" in the pays de Vaud. With the aid of the Comtesse de Rochefort and of the father of Madame de Pailly, ${ }^{1}$ the marquis succeeded in overcoming these scruples. She renounced the allowance that she received from her husband, but obtained some compensation in the form of a pension of fifteen hundred livres from the French government.

The life at Bignon during the years between the departure of Mirabeau's mother and the end of the boy's own home life, was one of pleasure little saddened by the domestic troubles of the marquis. ${ }^{2}$ The mother of the marquis and Madame de Pailly lived most happily together. At times a slight cloud arose, produced by the discussion of religious differences, but this virtuous woman, this strict Catholic, readily adjusted herself to a situation that substituted a Protestant and a woman bound to her son by no legal tie for the daughter-in-law whom she could not tolerate. The terms "digne maman" 3 and "bonne maman" ${ }^{4}$ with which Madame de Pailly refers to the mother of the marquis in her letters to the Comtesse de Rochefort are suggestive of the strange position that she occupied

1 In a letter to the Comtesse de Rochefort, the marquis, after referring to the scruples of Madame de Pailly, added: "Toutes ces choses, si elles étaient décisives, exigeraient certainement les sacrifices de l'amitié, mais ce serait sa mort, son père méme me le disait." The manner in which this liaison was encouraged by the father of Madame de Pailly and by the mother of the marquis is significant. Such relations, when they existed without scandal, seemingly affected but little the social standing of the parties concerned. The letter is quoted by Lomênie, La Comtesse de Rochefort et ses amis, 530 .
2 Ibid., I 55-2 I 6.
3 Ibid., 188.
4 Ibid., I93. 
in this strange household. In the other resident of Bignon, "la petite comtesse"- the Gräfin von Kunsberg, Madame de Pailly found a companion to whom she grew much attached and who evidently returned her affection.

There can be no doubt that from i 762 the influence of Madame de Pailly was dominant in the Mirabeau household and that this influence was not favourable to Mirabeau. She disliked him, or, more exactly, she did not like him. She did not regard his case as hopeless, however, remarking that "the worst that could be expected was that he would become a very disagreeable man. He might even please a certain class of people quite numerous in this world and the education that he has received will not be wholly lost." 1 Mirabeau was then fourteen years of age. The boy was ugly and resembled his maternal ancestors. Before $I 762$, this resemblance seemingly did not count very seriously against him; after I 762, it undoubtedly did. Perhaps the best proof that can be given to support this statement would be a reference to the favour enjoyed by the chevalier, due apparently to his beauty and to the fact that he was a true Mirabeau.

In the same letters to his brother in which the lack of sympathy for his oldest son is very marked and accompanied by a growing dislike for the boy, are to be encountered expressions of affection for the younger son and a most sympathetic attitude toward him. ${ }^{2}$ At eight years of age, his father described him as "very

1 Loménie, La Comtesse de Rochefort et ses amis, 185.

2 "Boniface, je t'assure, sera un excellent sujet. Il a de l'envie de plaire dans l'esprit et de la bonte dans le cœur, naturel à l'excès et ne pouvant souffrir la moindre supercherie pas même dans les jeux. Enfin, singulièrement né pour l'honnêteté, du reste un balourd à sa manière et peu applique, mais ayant de l'esprit et de 


\section{An Unhappy Family}

pretty," as "becoming each day un plus rare corps." 1 "He resembles you internally," wrote the marquis to the bailli, "at the same time that he resembles me externally, except that he is a better man. He has an excellent memory, but wishes to learn only what pleases him. He writes themes, the Lord knows, and marvellous versions." It was at this time that the marquis conceived the idea that has been referred to of dividing the heritage between the two boys. In his letters, a gloomy and unfavourable reference to the eldest son is, as a rule, followed by an affectionate mention of the younger.

Honore, or "the eldest" [as he calls him], will probably become a fool; Boniface is an interesting child ${ }^{2}$; the eldest is still much of a caterpillar and will have much difficulty in uncaterpillaring himself. The rogue of a Boniface is pretty and lively; in the matter of his Latin, he is getting on and can do well when he wants to; finally, he is as coquettish as a dog, he makes everybody love him, a little scamp by the privilege of his nature. ${ }^{3}$

In a letter written in August, 1763 , when Mirabeau was fourteen and his brother was nine, the father noted the "absolute platitude" of the eldest and then added, "As to Boniface, everybody says that he is all Mirabeau and he will make an amusing fellow on account of his vivacity and ardour for everything." If nothing happened, the marquis believed that they would be satisfied with the boy, "after overlooking many

fort juste."-Correspondance générale, iv., Ir8. The marquis to the chevalier, Paris, January I 5, I 762.

1 Ibid., iv., 264. The marquis to the chevalier, Paris, November 25, I 762; the same to the same, December 22, I 762 .

2 Ibid., iv., 294. The marquis to the bailli, Paris, April I9, I763.

3 Ibid., iv., 329. The marquis to the bailli, Bignon, July 19,1763 
things, of course." 1 "Boniface, who, to tell the truth, is the hope of our house" 2 are the words in which the father refers to the younger son in November, I763. In the following January, he spoke of him as "a character formed from infancy." 3 He believed that he "knew no character farther removed from that of a petit maître." The future was to prove the marquis a very poor judge of character.

Although the evidence is anything but abundant, it would seem to be sufficient to prove that during the critical period of his life, from thirteen to fifteen, young Mirabeau found himself in a domestic environment not at all favourable to the right development of his peculiar nature. His mother was no longer a member of the household; he was not in favour either with his grandmother, his father, or with Madame de Pailly; he saw his younger brother preferred to himself; he was an ugly duckling. The boy was precocious and sensitive. He must have understood the situation and have been profoundly affected by it.

I do not conceive it to be the office of the historian to pose as the critic of human actions. It has not been my purpose in this chapter to condemn the conduct of the different actors in this distressing domestic tragedy. I have endeavoured to describe it as carefully as the evidence would permit, that I might make clear the probable influence of such an environment upon the early life of Mirabeau. The boy as well as his parents would seem to have been a victim of the mariage de convenance.

- Correspondance générale, iv., 234. The marquis to the bailli, Bignon, August $x_{3}, x_{7} 6_{3}$.

2 Ibid., iv., 367 . The marquis to the bailli, Paris, November 20, I 763 .

3 Ibid., iv., 373. The marquis to the bailli, Paris, January $I_{5}, I_{7} 64$. 


\section{CHAPTER IX}

\section{MONSIEUR DE PIERRE-BUFFIÈRE}

\section{$\mathrm{T}$}

HE last week in February, I764, young Mirabeau, a stout, pock-marked youth of fifteen, arriyed at Versailles, where he appeared incognito, probably under the name M. de Pierre-Buffière. ${ }^{1}$ M. de Sigrais, the friend of the marquis who had agreed to take charge of the boy, was a " brave soldier, a good Latinist, a captain of cavalry, and a member of the Academie des inscriptions et belles-lettres." Although

1 Correspondance générale, iv., 384 ., The marquis to the bailli, Paris, February 28, I764. "Il est actuellement depuis trois jours incognito à Versailles." The marquis does not state in this letter what title had been given to his son. In a letter of June $2, \times 764$, the boy is referred to as M. de Pierre-Buffière. "C'était tout simplement," writes M. Charles de Loménie (iii., 23), "le nom d'une terre importante, près de Limoges, devant revenir au marquis du chef de sa femme, et qui lui permettait de prendre le titre de premier baron du Limousin. Nous ne jurerions pas que le marquis n'était mis quelque vanité à faire porter par son fils le nom de cette terre." This explanation of the choice of a title is very reasonable, but it should not obscure the fact that the boy had been deprived of his own title. Mirabeau left home in disgrace. Referring to his departure, the marquis wrote his son in $177^{\circ}$, "Je vous ai dit en sortant de chez moi que vous ne reverrez la maison paternelle que je ne vous scusse changé." Correspondance générale, vi. The marquis to the bailli, Paris, June I, I770. In May, I770, when Mirabeau was with his uncle in Provence, the marquis wrote to his brother: "Si tu continues et persistes à en être content, je te prepare un cadeau à lui faire, c'est d'obtenir qu'il prenne notre nom." Correspondance générale, vi. The marquis to the bailli, May $29, \times 770$. 
married, Sigrais had no children. His wife being first lady in waiting to the dauphine, the mother of Louis XVI., he resided with her for a portion of the year at Versailles. ${ }^{1}$

Of the experiment tried by the Sigrais family we know little more than that it promised much, but failed signally. In a letter to his brother the marquis described the manner in which he had worked on their feelings and induced them to take his son:2

"As to my eldest, who has given me, and still gives me, more trouble than all the rest of the family, do you know what action I have taken? He has now been for three days incognito at Versailles in the hands of the big Sigrais, who has taken charge of him. You know this worthy man, his appearance and manner. $\mathrm{He}$ is to have with him for some time yet a friend of his youth of the same cut and figure as himself, but stouter and more rustic. He will take the young man into the fields and be the good soldier while Sigrais will be the bad one. To describe to you the course that I took to win these worthy people, not only hiding nothing from them, but even heaping up the measure, would take too long. You will see at once that I touched the noble and almost romantic soul of Sigrais and that this success is the result of the reputation that providence has conferred upon me by paying me in the money of the esteem of honest people, which is worth as much as any other treasure. It is a matter of religion with this good man to do everything to succeed. As for myself, I hope at least to draw from it the consolation of having neglected nothing in the performance of my duty in this matter and in the attempt to correct nature. ${ }^{3}$

1 Loménie, iii., 22.

2 Correspondance génerale, iv., 384 . The marquis to the bailli, Paris, February $28,{ }_{764}$.

3 While Mirabeau was with Sigrais the bailli wrote to the marquis as follows: "Quant à l'aîné, je souhaite et même j'espère que le 


\section{Monsieur de Pierre-Buffière}

At the end of three months Sigrais, with tears in his eyes, announced to the marquis that he would remain the jailer of his son as long as he pleased, but he despaired of ever doing anything with him. "That means," commented the marquis, "that the inexplicable derangement of his head is incurable." 1 He had never been confident that the experiment would succeed. After the boy had been with Sigrais two months, the marquis referred to the possibility of his eldest son's becoming a good man as the result of punishment.2 It was his method of "correcting nature." There is no indication in this letter-the only one in which Mirabeau is referred to before his father announced the failure of the experiment-that Sigrais was succeeding. The marquis still entertained the idea of dividing the estate, even if the eldest should be reclaimed. Boniface, "who is always the same, an excellent child," was being educated in the school of the Barnabites at Montargis. The marquis informed his brother, with much satisfaction, that "Father de la Roque, who had especial charge of him, has written, in a letter to his brother that I was not expected to see, "I have never seen a child at the same time more active and more gentle.'" The marquis believed that he had every reason to be contented with his youngest son. ${ }^{3}$

Sigrais en tirera le parti le plus avantageux que son étoffe comporte. Il ressemble diablement pour la figure au grand père maternel. Peut-être que quand le monde le pressera de tous côtés et qu'il ne trouvera plus l'indulgence qu'il est impossible qu'on ne trouve pas dans la maison paternelle, son amour propre l'engagera au moins montrer ses défauts et cela les diminue à cet âge là." Correspondance générale, iv., 476. The bailli to the marquis, Malte, May 24, I 764 .

1 Ibid., iv., 465. The marquis to the bailli, Bignon, June 2, x764.

2 Ibid., iv., 396. The marquis to the bailli, Paris, April 24, 1764 .

3 Ibid., iv., 384 . The marquis to the bailli, Paris, February 28,1764 . vor $.1-12$ 
The failure of the residence with Sigrais to serve as "a transition from the paternal house to the liberty of the army," for which the marquis intended his son, induced him to send the boy to a military school not unlike the one in which he had received a large portion of his own education.

I wished [he said] for my own satisfaction, to give him the finishing touch by means of a public education and I sent him to the Abbe Choquard, who keeps one of the celebrated boarding-schools of the day, as they would not take him in the colleges in spite of all compliments. This man is severe and forces the punishment when necessary. This last trial made and completed, if there is no improvement, as I do not expect there will be, I will expatriate him bag and baggage.

In the same letter in which he threatened his eldest son with such cruel punishment he informed the bailli that they might regard Boniface "as pretty nearly the sole resource of our house." 1 Two weeks later he referred to his "two boys, one of whom, according to appearance, ought not to be counted. Everything turns upon the head of Boniface, who is still an embryo." 2

The school to which Mirabeau had been sent was in Paris, Barrière St. Dominique. It was not a reform school, nor had he, apparently, been sent there as a punishment for any particular misdemeanor. ${ }^{3}$ The

1 Correspondance générale, iv., 465. The marquis to the bailli, Bignon, June 2, 1764 .

2 Ibid., iv., $47 \mathrm{I}$. The marquis to the bailli, Bignon, June $1_{5}, \mathrm{I}_{764}$.

3 "Une satire sanglante, qu'il avait composée contre une amie de son père, l'a vait fait exiler de la maison paternelle, et reléguer dans la pension de l'abbe Choquard, où je le connus." This statement appeared in an article published by the Journal de Paris immedi- 
father did not want the son at home and had given such an account of him that the regular boarding-schools would not receive him. At the Abbé Choquard's he would be severely disciplined, but at the same time thoroughly prepared for entrance into the service.

Among Mirabeau's school-fellows were two young Englishmen, Gilbert and Hugh Elliot. The information concerning the character of the school and Mirabeau's life at this time is drawn chiefly from their letters. ${ }^{1}$

No complaints of harsh treatment have, however, been recorded in the letters of the Elliots. In a style of which the idiom soon became more French than English, they describe the little events of their school life; their studies in ancient and modern languages; their lessons in dancing, swimming, fencing, tennis, their military drill on Sundays, their parties in fine weather to Argenteuil, " a village on the Seine not to be compared to Richmond," and in the winter to the theatre to see Zaire, "a tragedy by Monsieur de Voltaire"; the changes in their uniforms from blue and gold in winter to blue and silver, with a blue silk waistcoat, in summer. These and similar topics form the staple commodity of the boys' letters. ${ }^{2}$

In a letter to his mother, written September $12,{ }_{7} 6_{5}$, Hugh described the celebration that took place at the school on the fête of St. Louis.

ately after Mirabeau's death (April 22, I 79r). The writer claimed to have been a teacher of mathematics at the pension of Abbe Choquard while Mirabeau was a pupil in the institution. There is nothing in the correspondence between the two brothers that gives any support to the statement quoted above. It is not probable, however, that the marquis would mention a matter of that kind to the bailli.

1 The Countess of Minto, A Memoir of the Right Honourable Hugh Elliot (Edinburgh, I868).

2 Ibid., 4, 5 . 
Our first appearance [he wrote] was in arms, after having performed military operations until dark. The place where we exhibited, which was in the middle of a plantation at the end of our garden, which was excessively pretty when illumined with garlands and lustres, was at once changed from a field of battle to a dancing-school. For having laid aside our arms we danced stage dances till ten o'clock, opera-singers warbling cantatas to the king's praises between every dance; then the whole was shut by a firework. ${ }^{1}$

One of the letters of Gilbert contains a description of a public examination:

The Abbe had thought to make a great coup by making the examinations open with a new exercise, which none of the troops in France will do until May; but, alas, it was throwing pearls before swine, for there was little else than ladies and clergymen to see it, who did not know the new from the old one. Our friend Mirabeau then repeated a long discourse in praise of mathematics, composed by the Abbé; and after a general clap, was examined on that part of his studies. I was examined after him on the same subject. ${ }^{2}$

Two years later, at the celebration of the fête of St. Louis,

Mirabeau pronounced an oration of his own composition entitled "Eulogy of the Prince of Conde compared with Scipio Africanus." It is mentioned by some of the journals of the time, probably at the instigation of the Abbe Choquard, who was desirous of calling the attention of the public to his establishment. The editor of the Bachaumont collection makes mention of the eulogy under the date of January, I757, and remarks, apropos of the young

1 A Memoir of the Right Honourable Hugh Elliot, 5 .

2 Ibid., 6. 
writer: "It is to be noted that this young eagle is already sollowing the flight of his illustrious father, and the anecdote becomes valuable for that reason. The son has more clearness, more elegance in his style, and his discourse is very well written." 1

The Elliot boys, especially Gilbert, became very much attached to Mirabeau. The friendship did not end with their school-days. Twenty years later, when Mirabeau was the guest of Sir Gilbert in England, the latter, writing to his brother, described their old comrade as follows:

Mirabeau, though considerably ripened in abilities, . . . is as overbearing in his conversation, as awkward in his graces, as ugly and misshapen in face and person, and withal as perfectly sufficient, as we remember him twenty years ago at school. I loved him then, however, and so did you, though, as he confesses, you sometimes quarrelled with him, being always somewhat less patient in admitting extreme pretensions than $I^{2}$

This retrospective portrait of young Mirabeau, drawn by a friend, would seem to prove that he possessed at this time in a well-developed form all the traits that composed his fully developed character. He was overbearing in his conversation, awkward in his graces, ugly and misshapen in face and person, and perfectly

1 Loménie, iii., 28; Bachaumont, Mémoires secrets, iii., I 58. According to Mirabeau, Lettre de M. de S. M. aux auteurs de la gazette litteraire, reprinted in the third edition of the Essai sur le despotisme, this eulogy and some of his verses were printed at this time. "Alors on imprima quelques bagatelles du comte de Mirabeau," and in a foot-note he adds, "Un éloge du grand Condé, composé pour une fête publique; quelques pièces de vers," etc. -Essai sur le despotisme, xix. (Paris, I792.)

2 Sir Gilbert Elliot, Life and Letters (3 vols., London, 1874), i., 87, note $\mathrm{I}$. 
sufficient, and yet men loved him. This power to draw men to him, so early displayed, he never lost; he exercised it upon his playmates at the Abbe Choquard's and upon the men who stood about his death-bed. During their residence in Paris the Elliots were in the charge of a tutor, Mr. Liston, afterwards Sir Robert Liston and English ambassador to Turkey; and "Mr. Hume, to whom they had been specially commended, showed them great kindness, often visited them and superintended their studies." Mirabeau was acquainted with Liston, and it is possible that he also came into contact with Hume. ${ }^{1}$

Shortly after Mirabeau's death the Journal de Paris contained a communication from one who professed to have been an instructor in the school of the Abbe Choquard. ${ }^{2}$

M. de Mirabeau [wrote this correspondent] was only fourteen years old when I found him in the military school of the Abbé Choquard, Barrière St. Dominique, where I was called to teach mathematics. I soon distinguished him from his fellow-pupils on account of the nature of his questions, and the promptness with which he found the solution for a problem. Outside of my class he did nothing; all that was studied in the school and did not appeal to his imagination appeared insipid to him; he wrote a miserable hand, which he never seriously undertook to improve. Seeing him totally unoccupied, I proposed to him that he come and work with me and had him read the Essay on the Human Understanding by Locke. While reading the first chapter of the second book, with which I

1 Writing to Hugh Elliot in ${ }^{7} 783$, Mirabeau inquired about Liston, whom he called "le bon Liston," and added, "s'il vit, il ne vous est sûrement pas étranger." Minto, 430. The reference to Hume is Minto, 6.

${ }^{2}$ Journal de Paris, i., No. I1 2. April 22, I791. 
had him begin, he fell into a profound revery. All at once awakening as from a dream, he cried, "There is the book that I needed." Memorable words that I have never forgotten. And he was only fourteen years old.

We read together the last three books of Locke's work. The astonishing penetration of young Mirabeau, his association of ideas, his singular reflections, caused me to conceive the greatest hopes of him. Before knowing me he had written very energetic verses with great facility, but the reading of Locke, which he finished in three months, made him neglect from that time on a talent that had been injurious to him.

The writer of this anecdote left the school the following year. Some time later he encountered Mirabeau in the Tuileries. Running to him, Mirabeau greeted him with "extreme vehemence," saying, "Ah! I shall never forget that you made me read Locke."

However much truth there may be in the anecdote concerning Locke-it certainly is highly probable, the boy being at this time fifteen instead of fourteen, and very precocious-the statements concerning his mathematical ability are supported both by words of Gilbert Elliot and by Mirabeau's own reference to his mathematical studies. "I pushed mathematics in two years," he wrote while at Vincennes, "beyond differential and integral calculus." 1 At another time he declared that he had studied mathematics "from his earliest youth." 2

In the Choquard pension Mirabeau remained for three years. Concerning the influence upon his character of the training received in the school, ${ }^{3}$ and the vicissitudes in his relations with his father during this time,

1 Lettres originales de Mirabeau, iii., 24. 2Ibid., ii., 289.

3 Mirabeau says of the training he received in the pension: "Il $\mathrm{y}$ apprit les mathematiques, et y réussit; étudia superficiellement quelques langues."-Essai sur le despotisme, xix. 
little can be said with certainty. Judging from the letters of the marquis to the bailli in their collected correspondence, the experiment was a success. After Mirabeau had been in the school about two months his father wrote to his uncle that " $M$. Choquard pretends that he has more than half conquered $M$. de Pierre-Buffière, and finally he does not send him back to me. That is a great deal."' In January of the following year he "was assured that a great change had taken place in his eldest son." Always sceptical, the marquis added by way of comment, "I am watching and keep my hands off." 2 The letters of the two years that follow contain no reference to Mirabeau. On March 31, 1767, his father announced that he was about to send him to the army. ${ }^{3}$

The letters quoted by M. de Montigny-the originals of which I have never seen-introduce deeper shadows into the picture and place the marquis in a more unfavourable light. These quotations are from letters addressed to the bailli and to the Comte du Saillant, the son-in-law of the marquis. Are they genuine? They may be as a whole, but how much of each quotation is an exact reproduction of the original it is impossible to say without a comparison with the originals. It is seldom safe to quote the language of the letters published by $M$. de Montigny; it may be permissible to give the substance of them. 4 In August, I764, the marquis learned that the boy had been receiving

1 Correspondance generale, iv., 486. The marquis to the bailli, Bignon, July $17,1_{7} 64$.

2 Ibid., v., Io. The marquis to the bailli, Paris, January 5, 1765.

3 Ibid., v., 270. The marquis to the bailli, Paris, March 31, I767.

4 I never quote the letters contained in the work of M. de Montigny when I have access to the originals or reliable copies of the originals. 
money from his mother. ${ }^{1}$ It was, perhaps, to prevent all such interference with the education of his son that the marquis gave orders that he should not be permitted to correspond with any person outside of the school. ${ }^{2}$ At the close of the first year, for reasons of which we know nothing, Mirabeau was to have been removed from the school and submitted to more severe discipline elsewhere. ${ }^{3}$ His comrades were so attached to him and so affected by the news of the misfortune that was about to befall him that they sent a deputation to the marquis bearing a petition signed by all of them asking for a suspension of the sentence. The marquis granted three months.

The reports from that time on must have been favourable, for the next quotation is from a letter written to the Comte du Saillant in February, I 766 , in which the marquis announced that he hoped to save his eldest son, although the boy had a long road to travel on the way to reform. ${ }^{4}$ Before the year had closed, the hopeful mood had passed and the marquis announced his intention of leaving his son with Choquard until he could send him to the north to remove him from the places where he might be a burden after the marquis's death. ${ }^{5}$

It is important that the attitude of the marquis toward his younger son during this period should not be lost sight of. He was as persistent in his fondness for the one as he was in his dislike for the other, and

1 Montigny, Mémoires de Mirabeau, i., 279. The marquis to the Comte du Saillant, August 30, I 764 .

2 Ibid., i., 279. The marquis to the bailli, October 31,1764 .

3 Ibid., i., 280 . The marquis to the bailli, August 7, 782 .

Ibid.

5 Ibid., i., 28r. The marquis to the Comte du Saillant, December I3, 1766 . 
continued to cherish the plan of marrying Boniface in Provence and making him the heir of the family possessions in that region. "We need a master of our patrimonial estates," he wrote to the bailli in March, I767. "Boniface has my character in wishing to be always on pleasant terms with those around him, bon camarade, for so they call him. He never quarrels, has a great memory, dissipation prodigieuse, a bon enfant. From you he gets his firmness and a truthfulness that is unique. Finally, he promises to be a bon sujet." 1

To establish external facts is at times not difficult; to explain these facts, to make clear the motives that led to the visible acts, is often impossible. Young Gabriel was ugly and resembled his maternal ancestors; his mother lived apart from his father and was at war with him; the boy was probably in communication with his mother and received money from her. Boniface was personally attractive and resembled his father; there is no evidence to show that he took any interest in his mother. The father disliked the one boy and was fond of the other. These are the facts that have led historians to attribute all the hostility of the marquis toward his eldest son to this maternal likeness and to the interest taken by the boy in the mother's cause. There is practically no evidence to show that Mirabeau, in his early years, ever took sides in this family quarrel. True, Madame de Pailly did not like him, but her attitude may be partially explained by evidence that has often been overlooked. Mirabeau was an extraordinary boy and not easy to manage. It is quite conceivable that without any

1 Correspondance generale, v., 270. The marquis to the bailli, Paris, March 3 , I 767. 


\section{Monsieur de Pierre-Buffière}

family quarrel, without any Madame de Pailly, his education might have been a failure and he might have turned out much the same sort of person that he finally became. It is quite possible that the main cause of trouble was the boy's disposition, while Madame de Pailly, his ugliness, his resemblance to his maternal grandfather, and the separation only served to aggravate the situation. It is possible, for motives are a matter of inference; but so long as psychological motives cannot be inferred with certainty from external acts, especially when these acts are few in number, and so long as the historian possesses no superhuman powers of divination, the careful student will hesitate to offer with any assurance an explanation for such phenomena as those involved in the relation of the Marquis de Mirabeau to his eldest son.

It is not necessary to assume that the marquis was actuated by harsh motives in removing his son from the Choquard pension. Mirabeau was eighteen years of age and, as his father intended him for the army, it was high time for him to begin the serious work of his life.

As to my boys [he wrote to the bailli, ${ }^{1}$ announcing his intended action] the eldest is still a cross; the world is full of trouble. I am going to send him as a volunteer (new style) to the roughest of military schools. A young man, but of the antique type, has founded it in his regiment. He pretends that the exclusive air of honour, united to a hard and cold régime, can restore lungs, even those that are naturally in very bad shape. I asked of him as mentor an officer who, without argumentation or talkativeness, has by instinct a disgust and natural disdain

1 Correspondance générale, v., 270. The marquis to the bailli, Paris, March 21, 1767 . 
for everything related to cowardice. He said that his man was such a one. I have, in fact, seen two fathers thank him for having created a son for them. I ought to neglect nothing. I am going, then, to follow this road.

When my son entered the service [he wrote later, ${ }^{1}$ ] you may infer from what you know of the past that I neglected nothing that he might be in good hands, were it for no other reason than that I might have nothing to reproach myself with. The Marquis de Lambert, to whom I had confided him, and who was pointed out to me on all sides as keeping the best and strictest military school, asked of me, at least for a time, a trusty domestic and one authorised to denounce him, above all one that he [Mirabeau] recognised as a mentor, not wishing to accustom him to think that espionage, even for a good motive, was a usual method. I proposed Grévin, whom he knew, and with whom he was delighted. I had difficulty in persuading him [Grévin] to consent to it for a time, but he is there.

The Marquis de Lambert, to whose care Mirabeau had been entrusted, was colonel of the regiment of Berri-Cavalerie, belonging to the light horse of the French army, at that time stationed at Saintes. He was the grandson of the famous Madame Lambert, and related to the Vassans. He did not, however, take the part of the Marquise de Mirabeau in her affairs with her husband, being a friend of Madame de Rochefort and a devoted disciple of the Ami des hommes. Although holding the rank of brigadier, the Marquis de Lambert was at this time but twenty-six years of age. ${ }^{2}$

On the nineteenth of July, $x_{767}$, Mirabeau joined his regiment. Saintes, the garrison town, charmingly

1 Correspondance générale, v., 359. The marquis to the bailli, Paris, August 7, I767.

2 Loménie, iii., 29. 
situated upon the banks of the Charente not far from Rochelle, is a quaint old place to-day and could hardly have been less so one hundred and thirty years ago. The broad, quietly flowing stream; the old Roman bridge connecting the two parts of the town and supporting a triumphal arch; the wide main avenue, with its great trees casting a deep shade, rising from the bridge over the hillside; the crooked, picturesque streets; the remains of the Roman amphitheatre; the impressive romanesque churches and the fine old façade of the palace of justice-this was the picturesque environment of the young volunteer. Life in such a place was certainly not a hardship.

Of Mirabeau's life during the first year we know practically nothing. Local tradition indicates a house in the Rue d'Alsace-Lorraine as the place of his residence, and reports that at one time he was confined in the tower of the old palace of justice. ${ }^{1}$ M. Charles de Loménie writes that "Mirabeau was one of the most insubordinate soldiers in the Berri-Cavalerie; he passed a portion of his first year of service in the prison of the regiment," yet he gives no proof and I have been able to find little more than this tradition to which I have referred. ${ }^{2}$ No reference to Mirabeau is found

1 I have repeated the tradition as it was given to me by $M$. Louis Audiat, librarian of the city library at Saintes and a local antiquarian.

2 The only additional evidence that I have found is in the report made in 1776 by the commission on lettres de cachet on Mirabeau's case: "Après une jeunesse beaucoup trop orageuse, avait été toujours en prison au regiment de Berri-cavalerie où l'on l'avait mis pour son école militaire sous le Mis. de Lambert."-Mémoire sur $M$. le Comte de $M$. (Archives nationales, K. 164, No. 2, 32). The value of this evidence is questionable. The commissioners undoubtedly had the statements of the marquis before them, and at the time this memoir was drawn up the marquis was extremely 
in the correspondence between the marquis and the bailli until April 21, I 768, or near the close of the first year. "The news from the other [Mirabeau] is good," runs the letter; "I am going to get him a commission." 1

On the twentieth of April, I768, the marquis addressed himself to Choiseul, asking that his son be made a second lieutenant in the regiment in which he had served for nearly a year.

I have a son [he wrote] whose youth was wayward. I prolonged and stiffened his education in every way and by every method, preferring to delay his entry into the service rather than have him ruin himself at the outset; when his age finally forced my hand I asked the best officers of my acquaintance which of the military schools was the strictest and most exact. All agreed in naming the regiment of Berri commanded by the Marquis de Lambert. I put him in this regiment as a volunteer. The young man submitted. He has now made himself esteemed and has never lacked wit nor talent. I waited until his colonel should say to me that it was time to ask a commission for him; he has sent me the mémoire that I have the honour to transmit to you; my son was nineteen years old the tenth of March. I was not aware that a copy of his certificate of baptism would be necessary; I have sent to his birthplace for it and I promise you to send it to the bureau in a short time. ${ }^{2}$

hostile to his son. A memoir of this character drawn up in 1776 could hardly outweigh the evidence of the marquis himself given in 1768 , that "the news from the other," meaning Mirabeau, "is good; I am going to get him a commission." At the same time that he made this statement to his brother, the marquis informed the minister to whom he applied for the commission that his son was "esteemed" in his regiment.

1 Correspondance générale, v., 399. The marquis to the bailli, Paris, April 21, I768.

2 The documents relating to Mirabeau's commission in the Berri cavalry were discovered by M. Brette and published in 1895 in the Révolution française, xxix., 255-264, under the title "Les 


\section{Monsieur de Pierre-Buffière}

The inclosed mémoire from the colonel was as follows:

The Marquis de Lambert requests M. le duc de Choiseul to be kind enough to procure for the Comte de Mirabeau a commission as sous-lieutenant réformé à la suite du régiment de Berry, where he has served for a year in the position of a volunteer. His birth is sufficiently well known so that it would be useless to add the ordinary certificates. The extract from the baptismal record is subjoined. ${ }^{1}$

M. Brette calls attention to "the cleverness with which De Lambert dwells upon the birth in order to avoid speaking of the conduct and the aptitudes of Mirabeau. These words, commission de sous-lieutenant reformé d la suite, testify to an attempt to reduce as much as possible his military position and consequently his responsibilities."2 It may be so, but in the face of the father's letter and of the absence of proof that at this time the colonel was dissatisfied with Mirabeau, the inferences of M. Brette seem hardly to be justified by the evidence. On the same day that Choiseul received the letter of the marquis Mirabeau was made souslieutenant sans appointements in the cavalry regiment of Berri. ${ }^{3}$

Some three months later, on a July day, the marquis was startled by the news that his son, having lost eighty louis at play, had deserted and that his whereabouts was unknown. The marquis asserted later in a letter to the bailli that the news did not disturb him. "On the contrary," he wrote, "I found myself relieved by the fact that he had been guilty of a prank

Services Militaires de Mirabeau." The originals are in the Archives administratives de la guerre, "au nom de Gabrielle-Honoré de Mirabeau, sans cote spéciale."

1 Révolution française, xxix., 257. $\quad 2$ Ibid., $258 . \quad 3$ Ibid., 259. 
similar to that of others." A few days later he was informed that

M. de Pierre-Buffière had been found in Paris, addressing himself to M. de Nivernois and opening against M. de Lambert a pack of recriminating lies, almost convincing by force of his eloquent effrontery. It was this action that dictated his arrest, and on seeing this hideous heap of contraverities and this ingratitude I felt the soul of my father reproach me for having hoped to do anything with this miserable being after so many trials." 1

Mirabeau was indeed at Paris and appealing to the Duc de Nivernois; as his father had stated. He had taken lodgings under an assumed name at the Hotel de Bretagne, Rue St. André-des-Arts, and writing to the Duc de Nivernois had begged him to act as mediator with his father and to grant him a hearing.

I dare to implore your intervention with my father [ran the letter] whom I shall find cruelly irritated with me on account of the inconsiderate act to which I was driven by vivacity, anger, and human respect. M. de Lambert, my colonel, affronted me twice in so outrageous a manner that I had the whole city murmuring at my patience, which was looked upon as baseness. I felt that my mind, prodigiously agitated, was getting beyond my control. The fear of committing the greatest of follies, the humiliation of seeing myself shamefully ridiculed, made me decide to leave Saintes. I set out by post, and whatever chances I may take in announcing to you my residence, I count sufficiently upon your justice and your goodness to confide to you that I am in Paris. Deign to conceal this from my father until you have been willing to hear me and to verify the facts I shall have the honour to state to you. I dare,

1 Correspondance generale, v., 467. The marquis to the bailli, Bignon, August 24, 1768. 


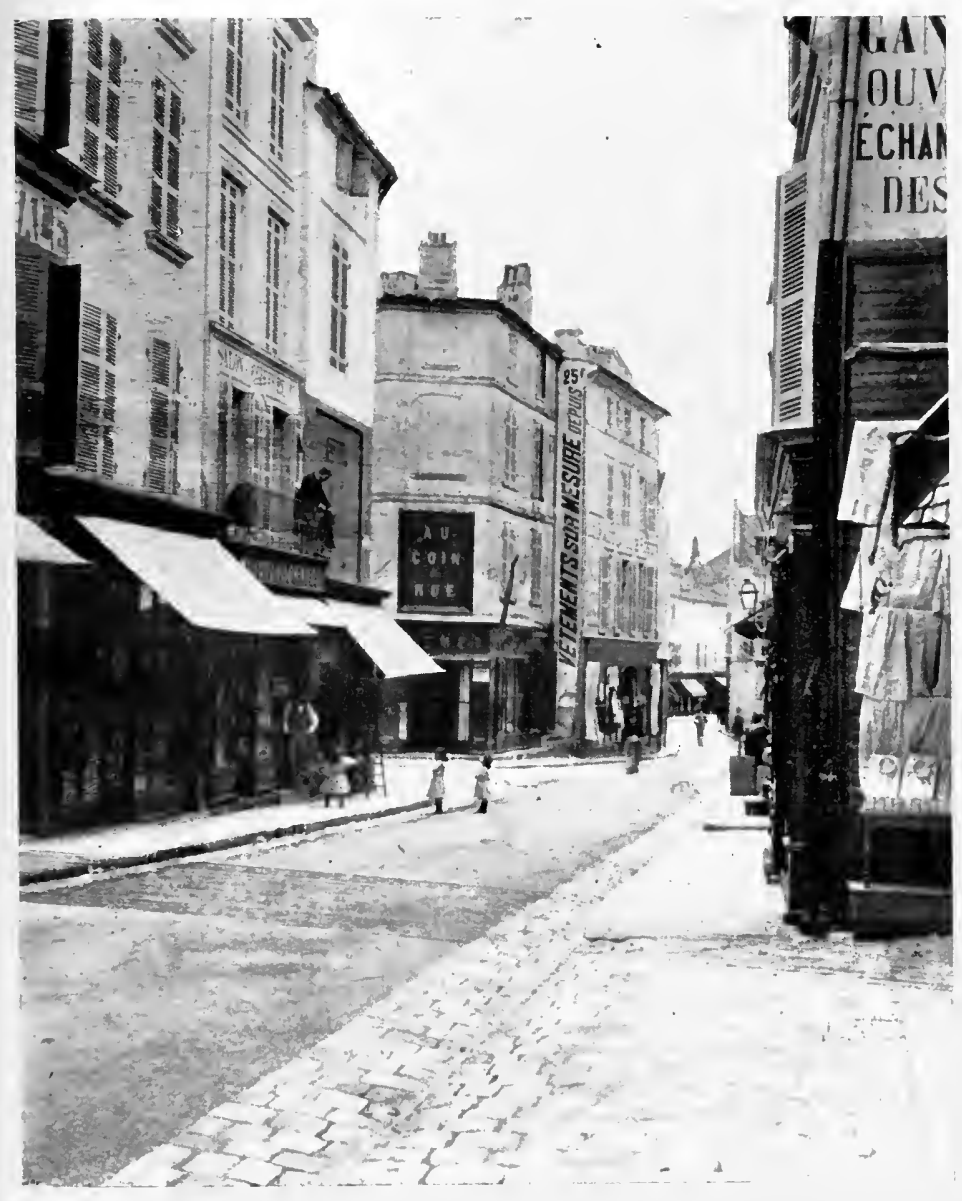

The Residence of Mirabeau at Saintes House bears the sign "Au coin de rue" From a photograph by H. D. Fling 



\section{Monsieur de Pierre-Buffière}

then, to supplicate you to send to the Hôtel de Bretagne, Rue St. André-des-Arts, a card upon which you will have been kind enough to give me your orders concerning the hour that I beg you to grant to me. This card, without name, presented to the porter, will be faithfully remitted to me and I shall take the liberty of calling upon you.

The letter bore the date of July $2 \mathrm{I}, \mathrm{r} 768 .{ }^{1}$

What were these affronts that had so affected the mind of Mirabeau that he deserted his regiment, even, it is said, abandoning ${ }^{2}$ his post when on guard, to save himself from the danger of committing some crime that he might afterwards regret? It was a love-affair. The story is told by M. de Montigny, but without the citation of evidence: ${ }^{3}$

The young and beautiful daughter of a constable of Saintes had pleased the Marquis de Lambert; she had also pleased Mirabeau; according to usage the second lieutenant had supplanted the colonel; the latter, already harsh by nature, already indisposed, authorised, stimulated by the father and by Grévin, insulted his happy rival, had him insulted, or allowed him to be insulted by a coarse caricature which set the whole regiment laughing at Mirabeau's expense; then Lambert called the authority of his rank to the aid of his irritated amour-propre; it was then that Gabriel, punished beyond measure, and unable to deceive himself concerning the cause, had, while on guard, abandoned his post and fled to Paris.

This account rests, as far as I have been able to discover, simply upon oral tradition. Certainly $M$.

1 Original in the possession of M. de Montigny, Aix en Provence.

- The memoir prepared in 1776 does not charge him with deserting his post, but states that he was sent to the Ile de Ré "pour avoir quitté et fui sans congé de ce régiment." Archives nationales, $\mathrm{K}$. I64, No. 2, 32 .

3 Montigny, Mémoires de Mirabeau, i, 288, 289.

vor. $x .-13$. 
de Montigny would have cited his documents, had any existed. "In the absence of proof," observes M. de Loménie, "it seems to us difficult to admit the exactitude of this grief. It is not easily reconciled with the general esteem of which the character of $\mathrm{M}$. de Lambert was the object. We shall see, elsewhere, on different occasions, that inventions of every kind cost little to Mirabeau's unscrupulous conscience." 1 It is not safe, as a rule, to infer particular acts from a man's general character. The inferences may or may not be true. We know very little about the character of the Marquis de Lambert, and what we do know does not render the story impossible. The evidence upon which the story rests is, apparently, worth little. Mirabeau makes no mention of his colonel as a rival, nor does he make any specific charges against him. In a letter written to his mother the following year he referred to Lambert as "a colonel unworthy to command officers who are better than himself." $\mathrm{He}$ added: Lambert "has employed all possible methods to destroy me. He has not succeeded." The historian must pass over the charge against the Marquis de Lambert, not because it is difficult to reconcile with a character concerning which little is known, but because the proof is lacking.

There was, however, a love-affair, even if the colonel was not one of the lovers. The father had believed that the gambling debt was the cause of all the trouble. He later wrote to the bailli that investigation showed that "it was a promise of marriage and all the follies at one time." ${ }^{2}$ There can be no doubt of this fact:

1 Loménie, iii., 3 r.

${ }_{2}$ Correspondance generale, v., 467 . The marquis to the bailli, Bignon, August, 24, 1768. 
we have Mirabeau's own word for it. In the letter to his mother already mentioned he referred to himself as "more unhappy than culpable," and added, "If I have sacrificed too much to love, I have given no cause for criticism as to the qualities of my heart and the knowledge relative to my profession." In the Lettres de Vincennes, in a mémoire addressed to his father, Mirabeau asked what he had done at this time that should have led his father to think of sending him to the Dutch colonies. His own answer was, "I had loved." I In another letter in the same collection he summoned his father to declare why he was detained on the Ile de Ré: "Let him allege any other reason, if he can, than an intrigue with a woman that made him fear a union mal assortie." 2

The Duc de Nivernois did not keep Mirabeau's secret. $\mathrm{He}$ communicated the news to the marquis and the Comte du Saillant, Mirabeau's brother-in-law, was "put, upon his trail" - to use the language of the marquis-

frightening him, drawing him on, and consigning him to the hotel de Nivernois, surrounding him with spies, and discovering that he was connected with a horde of brigands. His case won, he took him away by post, thirty-six hours later, to Saintes. There, in presence of the colonel, of the lieutenant-colonel, of his mentor, of Grevin, they made him confess at last, and they discovered that it is neither this nor that, it is a promise of marriage and all the follies at once. These worthy and zealous young men slip out and depart, and the Marquis de Lambert recovers his letters, comes back, and at once is taken ill, and I came very near losing this worthy young man who cherishes me and serves me like a son. ${ }^{3}$

1 Lettres originales de Mirabeau, i., 296. 2 Ibid., i., 189.

- Correspondance générale, v., 467. The marquis to the bailli, Bignon, August 24, I 768 . 
In a second interview, according to the marquis, who obtained his information from Lambert, the colonel

had read to him [Mirabeau] one of his letters that had been intercepted and that might have ruined him, cast it into the fire, and asked if he believed that a man capable of depriving himself of such weapons was an enemy. This act produced a sudden change; he broke off at once all his liaisons, promised to submit to imprisonment as a favour, asked to have Grévin left him, to be released only on the return of M. de Lambert, and to go back to his corps where he had so much to repair. The noble and sensible heart of M. de Lambert held out some hope to him. As for myself, I remarked to him [Lambert] that it was the displacement of the hammer of this fool from beneath the chime of the desperate prisoner and the passionate lover; that we could draw no other advantage from it than to transfer him without a scandal injurious to his family. ${ }^{1}$

Was it this intercepted letter that caused Mirabeau, fearing the action of his colonel and his father, to desert? The explanation is not an improbable one. It should be noted, however, that the real situation became known only after Mirabeau's return to Saintes, and that Lambert recovered the letters in the possession of the young lady only after the confession. The effect upon Mirabeau of Lambert's chivalrous action in burning the intercepted letter should not be overlooked. Mirabeau always claimed that his father had shown him little affection; that he had tried to discipline him by rigorous measures when he might have led him by kindly treatment. ${ }^{2}$ Undoubtedly the father was unsympathetic and unduly severe; undoubtedly the

- Montigny, Mémoires de Mirabeau, i., 299. The marquis to the Comte du Saillant, October I, ${ }_{7} 68$.

2 Lettres originales de Mirabeau, i., 295. 


\section{Monsieur de Pierre-Buffière}

boy was in need of sympathy and capable of attaching himself to those who loved him, but his intentions were always better than his deeds and he was always ready to condone his own faults.

The love-affair did not end here. "In I 770 Mirabeau was still in correspondence with the object of this first passion, through the medium of his sister, Madame de Cabris."1

The bailli was much incensed at the action of his nephew.

Your letter of the twenty-fourth of August, dear brother [he wrote] filled me with consternation, informing me, as it did, of the new pranks of M. de Pierre-Buffière, and fortunately the little hint that you dropped before prepared me. But after having ruminated three days since the receipt of your letter upon the unique course to take, I see only one way. It is for you to decide, after a very detailed inspection of the case, whether you ought to follow this course, that is to say, if the excesses of this miserable being are such that he should be forever excluded from society, and in that case Holland is the best of all. You are certain of never seeing reappear on the horizon a wretched being, born to cause chagrin to his parents and shame to his race. It is, I say, for you, after the examination of his acts and deeds, to judge if the heart is rotten: if it is, there is no resource. [Toward the close of the same letter he added:] I repeat to you, dear brother, this wretched being, if his heart is rotten, is without hope and in that case I know of nothing better than Holland. ${ }^{2}$

1 Loménie, iii., 34 ; Correspondance générale, viii., 284. The marquis to the bailli, Bignon, September 2, 1778 ; viii., 327. The marquis to the bailli, Bignon, November 18,1778 ; ix., 58 . Mémoire of the marquis, December 3, I 778. The marquis asserted that in I770 Madame de Cabris urged her brother to marry the young woman.

${ }^{2}$ Correspondance générale, v., 475,476 . The bailli to the marquis, 
It was not a simple amourette, as $\mathrm{M}$. de Montigny has called it ${ }^{1}$; it was the fear of a mésalliance on the part of the eldest son that appeared to enrage the uncle more than the father. It is not difficult to realise what the feelings of the bailli were, filled as he was with the pride of his race, when he learned of the narrow escape of the family from a disgrace like that formerly inflicted upon it by his younger brother. The more he dwelt upon it, the more serious it seemed and the more his anger increased.

I assure you [answered the marquis] that I agree with all that you have said to me, both for the present and the future. But these things are easier to plan than to execute, above all in the age in which we live and with a rogue who has all the intrigue of the devil and the intelligence of a demon. The Marquis de Lambert said to me the other day that he had divided the city and the province between reason and him, and that, in spite of his odious character, he is believed to have found in the city of Saintes 20,000 livres that are no longer there. ${ }^{2}$

Before hearing his brother's suggestion, the marquis

Mirabeau, September Io, I768. According to Mirabeau, his father assured him after their reconciliation in 1770 that in $I 768$ he had thought seriously of sending him to the Dutch colonies: "Qu'il me soit permis seulement de vous rappeler qu'après m'avoir reçu en grace, vous m'avez avoué dans une de vos lettres, que vous aviez été au moment de m'envoyer aux colonies Hollandaises, lors de ma détention a l'isle de Ré. Ce mot fit une profonde impression sur moi; il a prodigieusement influé sur le reste de ma vie: et voila pourquoi je vous le rappelle. Daignez réfléchir, en y pensant, que vous êtes prompt à envisager les partis les plus violens. Qu'avais-je fait à dix-huit ans, pour que vous eûssiez une telle idée qui me fait frémir encore aujourd'hui que je suis enseveli tout vivant dans un tombeau?"-Lettres originales de Mirabeau, i., 295, 296.

1 Montigny, Mémoires de Mirabeau, i., 289.

2 Correspondance gencrale, v., 489. The marquis to the bailli, Fleury, October I8, I 768 . 
had acted, sending Mirabeau to the Ile de Ré. "The bad subject is in prison," he announced in the same letter that informed the bailli of the escapade.

His brother-in-law, who has said so much in his behalf, is forced now to admit that a miracle will be necessary, and that such as he is, he is a sewer. All this is shocking for the head, the stomach, and the purse of your elder brother, and as you could do nothing in the matter, it seemed better to say nothing at all to you about it; but it is difficult to silence the heart in the presence of those whom we love and esteem. As I have domestic dragons of different kinds, for the present I would not have said anything more about it to you, had I not feared from your letter that you would accuse me of reticence toward you. 1

Reasoning from the fact that the lettre de cachet transferring Mirabeau to the Ile de Ré was issued by the minister of war, M. de Choiseul, and not by M. de Saint-Florentin, the minister who issued letters for matters of family discipline, $M$. de Loménie infers that his imprisonment was a military punishment for his desertion. ${ }^{2}$ It is possible, but it should be noticed that Choiseul would naturally deal with the matter because Mirabeau was an officer of the army, and also that the Marquis de Mirabeau evidently conducted the negotiations with the minister.

"I assume that he is caged now," wrote the marquis to his brother, September 21,1768 , "in the chateau of the Ile de Ré and well recommended to the Bailli d'Aulan. This determination was necessary, the

1 Correspondance générale, v., 467. The marquis to the bailli, Bignon, August 24, I 768 .

2 Loménie, iii., 33 . 
Marquis de Lambert not being able to keep him." 1 The colonel was eager to be rid of the troublesome lieutenant.

I have been occupied [wrote the marquis] in appeasing the impatience of M. de Lambert, who, without taking distance into consideration, had hardly written to me before he was seriously disturbed at not seeing all that he asked of me arrive, nor any plan of agreement. As I had asked of M. de Choiseul that there might be as little scandal as possible, he proposed to me to send an order to M. de Pierre-Buffière to carry a letter to the Marechal de Senneterre at Rochelle, who at once would have him arrested and conducted to the Ile de Ré. ${ }^{2}$

It was in this way, probably, that the first lettre de cachet was executed against Mirabeau, and he found himself a military prisoner in the citadel at SaintMartin on the Ile de Ré.

The Ile de Ré, the scene of Mirabeau's first imprisonment, is a picturesque island off the harbour of Rochelle, some three miles from the mainland. Its length is eighteen miles and its breadth three. The population to-day is nearly fifteen thousand, distributed among several towns. The largest is Saint-Martin de Ré with two thousand inhabitants. At the entrance to the harbour of Saint-Martin rise the outworks of the fortress to which Mirabeau was consigned. Although now used as a depot from which convicts are shipped to New Caledonia, the citadel has changed but little

2 Correspondance générale, v., 467. The marquis to the bailli, Fleury, September 21, I 768.

2 Montigny, Mémoires de Mirabeau, i., 294. The marquis to the bailli, September I6, I768. No letter of this date appears in the Correspondance generale. There is a letter of the date of September 2I, but it does not contain the quotations given by Montigny. 
since the days when it was occupied by its most distinguished prisoner. The diminutive harbour with its fishing craft; the town with its quaint antique streets shut in by stone houses whose white walls reflect the dazzling rays of the southern sun; the attractive old town square with its ancient trees; and, close by, the house formerly the home of the governor of the island, now occupied by the village school; beyond the town, the vine-covered fields; toward France, the waters of the Atlantic-these things to-day form a not unpleasant picture. It certainly was not a disagreeable place of exile, and in the mind of Mirabeau few unpleasant recollections were to be connected with it. The governor of the island, the Bailli d'Aulan, was not a harsh jailer, although the marquis had instructed him that the young man "was fiery, wrongheaded, and a liar by instinct." 1 The Comte de Broglie has called D'Aulan "the happy king of the Ile de Ré, the happiest region of France." He was a grand-croix, commander of the temple of Agen, maréchal de camp of the armies of the king, and "the delight of the island." With his six feet of stature and his distinguished face, the Bailli d'Aulan was a worthy representative of the king. ${ }^{2}$

It is not probable that Mirabeau was closely confined

\section{Loménie, iii., 35.}

2 The local histories of the island contain notes upon D'Aulan. It is from one of these by M. Theodore Phelippot that I gathered the data upon D'Aulan found in the text. The hospital of Saint-Honoré at Saint-Martin possesses a rather striking portrait of the bailli, which the sisters were kind enough to show me. It is the face of a man of abundant good-nature and one not likely to prove a harsh jailer. The marquis wrote of him: "La réputation du Bailli d'Aulan est excellent; c'est encore un nouveau témoin que je me procure et un nouveau appui de décision dans tous les cas." -Correspondance générale, v., 476. The marquis to the bailli, Fleury, September 21,1768 . 
in the citadel. Local tradition points to a room in the vicinity of the chapel as the one that he occupied, ${ }^{1}$ but he soon won the favour of the governor, and went and came much as he pleased. Although Grévin remained with him, the surveillance did not prevent Mirabeau from contracting debts nor even from corresponding with his mother, from whom he received financial aid. ${ }^{2}$ All this was a violation of the marquis's orders, but the son, as the father expressed it, " had bewitched the Bailli d'Aulan-who contrary to my orders allows him to promenade in the citadel, - my friends, and everybody." 3 He was not only permitted to promenade in the citadel, but even "to go to the city [Saint-Martin or Rochelle] to dine in style." 4 The bailli was not the only one that Mirabeau bewitched. A certain Chevalier Bréchant received the letters from his mother, and Mademoiselle de Malmont, the sister

1 The search for material both at Saintes and at Saint-Martin was disappointing. The local archives in both these places had been destroyed by fire a short time before my visit. From Dr. Kemmerer, a resident of Saint-Martin and one of the historians of the island, I learned that Mirabeau, according to tradition, occupied a room in the citadel next to the chapel, but as there were three equally near the chapel the information was not very definite. The only change in the citadel, I was told, had been the construction of an inner wall between the main entrance and the chapel. The building that Mirabeau is supposed to have occupied is of stone, one story in height, with rooms not at all unattractive.

2 Mouttet, Mirabeau en Provence, 24-26: "Je compte, ma chère Maman, sur le petit secours pécuniaire que vous me promettez, le nouveau m'est nécessaire pour des dettes urgentes et forcées que j'ai faites dans ce pays-ci."

${ }^{3}$ Montigny, Mémoires de Mirabeau i., 300 . The marquis to the bailli. M. de Montigny refers to a letter of February 15, I769, for this quotation; but this letter, found in the collection that I have used, contains no such matter.

4 Loménie, iii., 35, quoted from a letter of the marquis of January $\mathrm{I}, \mathrm{I} 769$. 


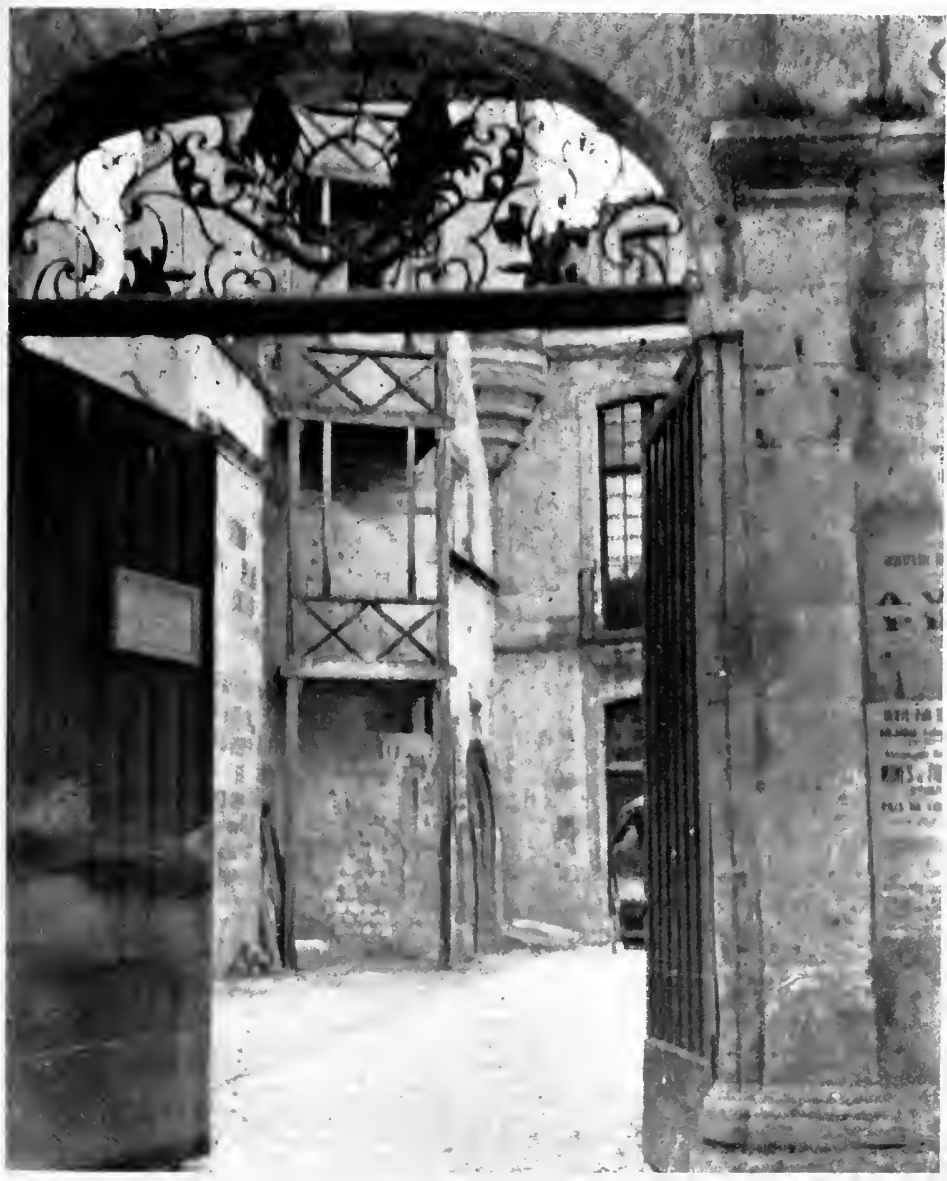

Palais de Justice at Saintes

From a photograph by H. D. Fling 

of the lieutenant of the citadel, performed a like service for him. ${ }^{1}$

Mirabeau remained seven months on the Ile de Ré. At the end of six months the marquis realised that it would be difficult to prolong the imprisonment.

The fact is [he wrote to the bailli on the fifteenth of February, 1769] that it is necessary to end this affair; that I do not know how to keep his eldest brother in cage later than the spring; that he asks to go to Corsica and interests the Bailli d'Aulan and my friends and Grévin in this request. I know well that, once free, he will end in having himself locked up for good before three months have passed; but the theatre of his follies is his passage through Provence. ${ }^{2}$

On the twenty-seventh of the same month the marquis had decided to grant his son's request and to allow him to join the expedition against Corsica. "What you tell me, however," ran the letter, "causes me to decide upon my course. I cannot keep $M$. de Pierre-Buffière any longer in cage and I cannot miss the occasion offered by Corsica; so be assured that next month he will pass through Provence, but so carefully guarded and so rapidly that you will not even hear of it." 3

A few days later the news of the decision had reached Mirabeau. On the fifth of March, $x_{7} 69$, he wrote to his mother: "My affairs have taken a more favorable turn; the Bailli d'Aulan, governor of the Ile de Ré, is soliciting the revocation of my lettre de cachet and it appears to be decided that I shall go to Corsica in a short time." 4

1 Mouttet, Mirabeau en Provence, 24-26.

2 Correspondance générale, vi., 65,66 . The marquis to the bailli, Paris, February I5, 1769.

3 Ibid., vi., 72. The marquis to the bailli, Paris, February 27 , 1769 .

4 Mouttet, Mirabeau en Provence, 24-26. 
The Bailli d'Aulan interested himself in securing the release of his prisoner, but the important party in the transaction was the father. This is demonstrated by an official document bearing the date of March ${ }_{13}$, I $_{7} 69$.

The twentieth of April, I 768 [runs the record], the son of M. le Marquis de Mirabeau obtained the rank of second lieutenant in the cavalry regiment of Berri. He had served in this regiment a year as a volunteer. $\mathrm{He}$ has been detained since the past year in the citadel of Ré for misconduct. M. le Marquis de Mirabeau observes that his son has urgently requested permission to take part in the campaign against Corsica, and that M. de Viomenil is willing to take charge of him and send him under fire. $\mathrm{He}$ requests that he be attached as second lieutenant of infantry to the legion of Lorraine. $\mathrm{He}$ desired that monseigneur would kindly grant to him some appointments; he leaves that matter to his sense of justice; he observes that his son has served for three years without having any. In order that his son may join the legion of Lorraine, he asks that the revocation of the lettre de cachet that detains him in the citadel of Ré be sent to M. le Chevalier d'Aulan. ${ }^{1}$

It follows from this document that Mirabeau was imprisoned for misconduct, and was released at the request of his father. On the very day when this record was made the marquis announced that "the orders for his liberation have been sent," 2 indicating that he was in close touch with all that was taking place. Hoping little good from this latest experiment, the marquis, as usual, endeavoured through repression to diminish the evil consequences of it.

1 La révolution française, xxix., 259.

2 Correspondance générale, vi., $80,8 \mathrm{I}$. The marquis to the bailli, Paris, March I3, I769. 
On the thirteenth of March the orders for Mirabeau's release had been given and his route across France had been decided upon. On the fourth of April, at the latest, he was to join the legion of Lorraine at the Pont Saint-Esprit. He was to serve in the infantry.

The Baron de Viomenil, colonel of this legion [wrote the marquis], has been represented to me as just the man that he needs, and that service also for his fiery spirit, which imagines that it will devour everything, but which will devour nothing but a plentiful supply of saber strokes, if he has the nerve to face them. He has been recommended to everybody and I had an opportunity to discover how people like to compliment those who are in trouble. M. de Vaux himself said to me that they would hang him at public cost if he proved unworthy of his father, but that otherwise he would be favoured by everybody. He is going then with Grévin. He has orders to remain incognito until he has embarked; I assure you that that is very important, for he could not exist twenty-four hours without getting into some kind of a scrape and replying to an act of politeness with an insult. ${ }^{1}$

The bailli replied that if $M$. de Pierre-Buffière passed that way and called upon him, he would receive him, ${ }^{2}$ but the marquis assured his brother that he had given orders to the best of his ability that his son should pass incognito; "and surely," he added, " he will not go to see you at Mirabeau." 3

Events seem to have justified the preventive measures taken by the marquis. Drawing his information from Grévin, who accompanied his son, he described

1 Correspondance générale, vi., 8०, 81. The marquis to the bailli, Paris, March I3, I769.

2 Ibid., vi., 83. The bailli to the marquis, Mirabeau, March 7, 1769 .

3 Ibid., vi., 83. The marquis to the bailli, Paris, March 20, I 769. 
the passage of the young man from Rochelle to Toulon in most vigorous language:

This miserable Pierre-Buffière left the Ile de Ré a hundred times worse than he entered it, not on account of his comrades, but because of the lapse of his own folly. He fought at Rochelle, where he remained only two hours. I have had news from poor Grévin from Saint-Jean-d'Angely and from Puy. He says that he goes cursing, striking, wounding, and vomiting a rascality that has no equal. ${ }^{1}$

M. de Montigny, citing a letter of Mirabeau to his brother-in-law, M. du Saillant, asserts that in the duel fought at Rochelle Mirabeau was not the aggressor. An officer, dismissed in disgrace from his regiment, with whom Mirabeau refused to associate, was the real cause of the trouble. ${ }^{2}$

The soul of the marquis was disturbed more, perhaps, by the debts that his son contracted than by his 'escapades.

Without paying for his pranks and a multitude of notes [he wrote] he has devoured more than ten thousand livres in the last eight months, and the most of that time he has been in prison.... The villainous notes of that man terribly wound my soul, although well prepared and accustomed to vomit him up. . . . He has, in addition to his other good qualities, that of borrowing from all hands: sergeants, soldiers, all are the same to him. ${ }^{3}$

"After a painful journey, and even a perilous one in the mountains of Auvergne and Vivarais, which he

1 Correspondance générale, vi., Ioo. The marquis to the bailli, Paris, April 10, I769.

2 Montigny, Mémoires de Mirabeau, i., 302. M. de Pierre-Buffière to the Comte du Saillant, March 20, 1769.

${ }^{3}$ Correspondance générale vi., 100. The Marquis to the bailli, Paris, April ro, I769. 
was obliged to cross in snow twelve feet deep," Mirabeau finally reached Toulon and embarked on the eighteenth of April for Corsica. ${ }^{1}$ To be rid, for some time at least, "of an odious generation that keeps me without ceasing with a sword above my head and coals under my feet," 2 was a great relief to the marquis. Grévin returned to Paris by way of Mirabeau and remained for some time with the bailli, who thus had an opportunity to study the man that had acted as a mentor to his nephew. "He does not appear to me to be very admirable," was the opinion that he expressed to his brother. ${ }^{3}$ The marquis himself referred to him as "jealous by nature," 4 and on another occasion he criticised him for not maintaining a stricter surveillance over his son at Saintes and on the Ile de Ré. ${ }^{5}$

The Corsican campaign was not of long duration. Mirabeau landed the last of April, I 769 , and the fighting was over in June. Although he saw little active service, he proved that he had a real genius for war and was a worthy descendant of Jean-Antoine. He won the good opinion of his superior officers and the affection of his associates. The major of the legion, the Chevalier de Villereau, declared some years later that "he had never known a man with greater talents than the

1 Correspondance générale, vi., Ioo. For the passage through the mountains see Montigny, Mémoires de Mirabeau, i., 303, who cites a letter of the marquis to the bailli of April 22, 1769. No letter of that date is to be found in the collected correspondence.

2 Ibid. The marquis to the bailli, Paris, April Io, I769.

3 Ibid., vi., 209. The bailli to the marquis, Mirabeau, September 23, I769: "Mais l'homme à qui tu l'avais confié et qui a passé ici quelque temps ne m'a pas paru bien admirable."

-Ibid., vi., I39. The marquis to the bailli, Paris, May 30, I 769.

5 "Grévin et puis tous les supérieurs de ce misérable ont laisś aller beau par le plus bas de manière."-Ibid., vi., I46. The marquis to the bailli, Paris, June 14,1769 . 
Comte de Mirabeau for the profession of arms, if time had rendered him discreet." 1 Mirabeau wrote in later years that this man "loved me much and declared that I was a great officer in embryo." 2

Here for the first time he displayed the talent for hard work and the determination to master the thing in hand that were so characteristic of the man. "What I am most of all," he once wrote to his sister, "or I am much deceived, is a man of war, because there alone I am cool, calm, gay without impetuosity, and I feel myself grow in stature." 3 He has himself described his enthusiasm for his profession and his efforts to master its minute details:

Reared in the prejudice of the service, fired with ambition, and avaricious for glory, robust, audacious, ardent, and yet very phlegmatic, ${ }^{4}$ as I proved myself in all the dangers that $I$ encountered, having received from nature an excellent and rapid coup d'cil, I had reason to believe myself born for the service. ${ }^{5}$ All my views had, then, been turned in this direction, and although my mind, famished for every kind of knowledge, was interested in all sorts of things, ${ }^{6}$ five years of my life were devoted almost exclu-

1 Loménie, iii., 38 . The remark was made in 1787 and quoted in a letter of the marquis.

2 Lettres originales de Mirabeau, i., 162.

3 Montigny, Mémoires de Mirabeau, i., 329. Mirabeau to Madame du Saillant, September I r, 1780 .

- Lettres originales de Mirabeau, ii., 258 : "Si moi, qui te parle, me sens bien la force d'en renverser quelques bataillons en sifflant dessus, c'est que la vie dure que j'ai menée, et les exercises violents que j'ai aimés (nager, chasser, escrimer, jouer à la paume, courir à cheval) ont réparé les innombrables sottises de mon éducation."

s Boniface expressed the same opinion: "Il [Boniface] a opinion de ses talents militaires et dit que c'est pour ce metier-là qu'il était fait."-Correspondance générale, x., 276. The marquis to the bailli, Paris, April 8, 1782.

- Mirabeau had been an omnivorous reader from his childhood 


\section{Monsieur de Pierre-Buffière}

sively to military studies; there is not a book on war in any language living or dead that I have not read; I can show extracts from three hundred military writers, extracts studied, compared, and annotated, and memoirs that I wrote upon all parts of the profession from the greatest objects of war to the details of engineering, of artillery, and even of the commissariat. ${ }^{1}$

In the period between the close of the campaign and his return to France Mirabeau was engaged in making a study of the island, its inhabitants, manners and customs, and history.

He perceived everywhere the traces of the devastations of the Genoese, the vestiges of their crimes; and by this mark of despotism he recognised his enemy. His heart, palpitating with indignation, could not contain itself; his imagination, filled with ideas, flowed over. He wrote; he traced a rapid sketch of the Corsicans and of the crimes of the Genoese. This work was taken from him by his father; it was very incorrect, without doubt, but full of animation, of truth, of ideas, and of facts carefully observed in a country of which no correct notion had been given, because mercenary writers or fanatic enthusiasts had alone undertaken to speak of it. ${ }^{2}$

The history dealt chiefly with the forty years previous to the French occupation of the island. He had also

up. He was, according to M. de Montigny, "dès l'âge de quatre ans . . . avide de lectures.-Il s'emparait de tous les papiers qui lui tombaient sous la main."-Montigny, Mémoires de Mirabeau, i., 243. Mirabeau himself refers to his fondness for books while at school in Paris: "Il empruntait toutes sortes de livres, les lisait sans méthode et sans autre objet que celui d'assouvir son insatiable soif de savoir."-Essai sur le despotisme, xix.

1 Lettres originales de Mirabeau, iii., 2 I .

2 Essai sur le despotisme, xxi.; Lettres originales de Mirabeau, i., Igo.

vor. $1-I_{4}$ 
prepared a description of the island, which he had studied "foot by foot," "with all possible political, economic, and historical details." 1 The history, he claimed, was prepared at the instigation of Buttafuoco. ${ }^{2}$ " He took possession of the Corsicans, he had all their papers." 3 Mirabeau declared while at Vincennes that the "deputies of the three estates of Corsica" besought his father to allow the work to be printed, but the marquis refused.4 This statement should be confronted by the charge made by the marquis that his son "seduced a man in order to get possession of memoirs that a priest of the country had made; he promised this man to pay him well and to return the memoirs. This man wrote a complaint to the late $M$. Gerardi, officer in the regiment Royal-Italian, who informed the Duc de Nivernois." 5

From evidence such as this it is impossible to get at the truth of the affair. Mirabeau undoubtedly made a study of the island and its people, even if the motives for doing so were not those given by him in later years. It is not inherently impossible that he procured material in the way indicated by his father, for it is in keeping with methods employed by him throughout his later life, but it would be unscientific to state as a fact a thing that rested on a scrap of third-hand evidence. The matter of first importance is, however, the early development of the inquisitive spirit that never allowed him to rest; that made a great

1 Montigny, Mémoires de Mirabeau, i. 3 r 7 .

2 Correspondance générale, vi., $33^{\circ}$. The bailli to the marquis, Aix, May 21, r770; ibid., vi., 375-380. The bailli to the marquis, Aix, August 23, 1770 .

${ }^{3}$ Montigny, Mémoires de Mirabeau, i., 316. The marquis to the Comte du Saillant, May 14, 1770.

- Lettres originales de Mirabeau, iii., 73.

${ }^{5}$ Loménie, iii., 38 , note 2. 


\section{Monsieur de Pierre-Buffière}

questioner of him, a laborious student, and an untiring investigator. It was no accident that made Mirabeau a leader in the National Assembly; he had prepared himself for leadership by twenty-five years of severe mental effort such as few men are capable of.

To make the Corsican episode typical, not even a love-affair was lacking. From Vincennes he wrote of this early love to a woman whose name has become inseparably associated with his. "Yes, Madame, yes," he wrote to Sophie de Monnier, "Maria Angela is a very pretty name; and when I was jealous of some one (a thing that did not often happen, for I was very lukewarm) she addressed injurious remarks to him, or struck him, or as an honest Italian she gravely proposed to me to poniard him." We might have known more of this affair but for the well-meaning censorship of M. de Montigny. He declined to dwell upon Mirabeau's gallantries in the island,

of which, happily, he has made public only a brief and succinct mention. Not that we have not had in our possession long details, written by himself, of a very spirituelle originality; but we at first put them aside and afterward destroyed them, because, as we were determined to keep within the bounds of the respect which is due to our subject and our age, to the public, and to history, we would add nothing to the facts, and above all to the suppositions of this kind, which are already to too great an extent attached to the name of Mirabeau. ${ }^{1}$

M. de Montigny undoubtedly had a right to destroy his property if he wished to; moreover, the attitude of the historian toward his subject will always differ from that of a son toward his adopted father. The

1 Montigny, Mémoires de Mirabeau, i., 312. 
dictates of science are not always to be reconciled with the dictates of affection.

Mirabeau was absent from France a little more than a year. During this time he is seldom mentioned in the correspondence between the brothers. The marquis was arranging a marriage for his daughter Louise at the time of Mirabeau's departure, and hoped to carry the thing to a successful conclusion, "provided," he wrote to the bailli, "this unhappy fool in Corsica who devours me, will let me get my breath." $1 \mathrm{He}$ sometimes regretted the loss of his first-born son. "If providence," he exclaimed, " had intended to grant me a period of repose at a reasonable age, it would have left me the son that it gave me twenty-five years ago. The one [Boniface] who is now our only hope is only fourteen and more of a child than one is at three." 2

The bailli had held numerous conversations with Grevin about his nephew and had reached conclusions that were not so pessimistic as those of his brother. "From what Grévin has said to me in several conversations about $M$. de Pierre-Buffière," he wrote to the marquis, "I do not see that there is anything desperate yet about his case. Perhaps age and reason will straighten it all out. I do not hope that he will ever be a man worthy of you on the side of the heart, but an ordinary man. It is bad enough to place at that notch our denomination that has never been there, but what is to be done about it?" 3 The marquis replied by criticising "Grévin and all the superiors of this miserable fellow" for letting him have his own way. ${ }^{4} \mathrm{He}$ - Correspondance générale, vi., II5. The marquis to the bailli, Paris, April 28, I769.

2 Ibid., vi., I30. The marquis to the bailli, Paris, May 18, 1769.

3 Ibid., vi. The bailli to the marquis, Mirabeau, June 2, 1769.

4 Ibid., vi., I48. The marquis to the bailli, Paris, June 14, 1769. 
never doubted that the failure of his training was due to the inborn badness of his son or the incapacity of his teachers and superiors. As hopeless as the task seemed to be, he must do his duty that he might be without reproach.

As long as I shall live [he wrote in June, I 769] it will be my duty to follow and to assure the lot of my children and of our house. If I can save this unhappy eldest, I have told you that I would part with the one who is after my own heart and I would give him to you. At fifty, you will have begun the profession of father of a family. . . . But, finally, you will see Boniface ${ }^{1}$ this autumn; everything is as yet in the shell, he is nothing. It is necessary to finish his education. We must wait for the other, who would get away from the devil and who has a dozen of them in his body, must keep an eye on him and restrain him, and be sure that the people of this age have only cold praise for honesty in retirement. I was very much devoted to your father. I have received so much of that. A well-born child can get on without control, but a slippery subject is not held in check at a distance, when he fears only letters and disapprobation, and he certainly has more people like himself in places of power and credit than his father has. ${ }^{2}$

The marquis had evidently found the youth that. "could get away from the devil and had a dozen of them in his body" an extraordinary child, even if extraordinarily bad and exceedingly difficult to control. The term "honesty in retirement" refers to the marquis, whose talents were not sufficiently appreciated

1 Almost without exception he refers to the younger son as Boniface; the older boy is never called by his name, but is always referred to as "the eldest," " that miserable being," "that unhappy fool," etc.

${ }^{2}$ Correspondance générale, vi., I56, 157 . The marquis to the bailli, Fleury, June 19, I769. 
by the government. The closing expressions of the letter would seem to indicate that the marquis already foresaw the part that public officials might take in the troubles between himself and his son. At Paris, at Saintes, and on the Ile de Ré, Mirabeau had given proof of a remarkable power of winning those with whom he came in contact. The fear that the marquis here expressed casts a curious light upon his attitude toward his son. The attitude is certainly not a fair one. The assumption always was that the boy never could amount to anything. In August of this year, while Mirabeau was in Corsica, the marquis represented that his son-in-law, Du Saillant, was pleading in behalf of the absent son. "He does not cease to beg of me, wrote the marquis, "that in case he [Mirabeau] is finally condemned where he is, I should leave him to him [Du Saillant] for a year before shutting him up for good." 1 At this time nothing had been heard from Corsica. In September the marquis had heard nothing later than the news that Vioménil had embarked, and as no news is good news, he was happy "I never wake up a sleeping cat," ${ }^{2}$ was his concluding observation.

1 Correspondance générale, vi. I78. The marquis to the bailli, Fleury, August 15, 1769.

2 Ibid., vi., I91. The marquis to the bailli, Fleury, September 5, r769. 


\section{CHAPTER $\mathrm{X}$}

\section{MONSIEUR DE PIERRE-BUFFIÈRE (Continued)}

$\mathrm{S}$ the time for Mirabeau's return from Corsica
approached, the marquis began to consider
seriously the question of how he should be treated. Nothing had happened to justify "shutting him up for good," nor could the marquis venture to set him aside for his younger brother. In a letter of February 2I, he reviewed the situation:

It is necessary to consider, dear brother, if, independent of the other children, I shall not have enough to do with this Corsican filibuster, who will soon be twenty-one years old and who, in view of the intellect and talent that he has combined, at least up to the present time, with a villainous heart, would supply more occupation than is reasonable for a whole areopagus. . . . And, furthermore, this idea that I had, at the time when his brother seemed going to the bad, of considering Boniface our only hope, would have its drawbacks to-day. . . . In accordance with my duty, I have always avoided everything that would seem to create an appearance of predilection and jealousy between them. ${ }^{1}$

The marquis may have believed that he was acting in that way, but the evidence certainly does not bear him out in his statement. That it was absolutely

1 Correspondance générale, vi., 272. The marquis to the bailli, Paris, February 21 , 1770. 
impossible for him to maintain a fair attitude toward his eldest son, is illustrated by a remark to the bailli in March, 1789 : "As to the eldest, I took his measure long ago. Be sure that the best thing that he may do in his life will displease you more fundamentally than the worst thing that the youngest may do." 1

The reports from Corsica were so favourable that it . was difficult for the marquis not to be influenced by them. "The eldest," he wrote to the bailli in April, I770,

seems to desire to be reasonable and to submit to control. He has shown marked valour and intelligence. As to talent and intellect, an active head and eight hours of study a day. It is perhaps unique, but God knows what kind of a head we shall see. At the request of his chief, I asked for a captain's commission. M. de Choiseul accorded me a company of cavalry. I refused absolutely, not wishing either to leave him unemployed or to have him enter a new corps. ${ }^{2}$

It was in March that the offer of Choiseul had been refused. The reasons for the refusal by the marquis are given in full in a letter addressed to the minister on the thirty-first day of the same month:

I have not concealed from you, Monsieur le duc, that my son is a madcap, and that, furthermore, he has some shocking traits of character. Such he was in the regiment of Berri; the Bailli d'Aulan, who had him for six months in his citadel, on turning him over to me did not conceal from me his conviction that in his day they would soon have been rid of him. M. de Viomenil sustained him and controlled him with a rare goodness; he was known in the corps, it was noted that he was willing to fight; he was received as a pupil, and it became a point of honour to make

1 Correspondance générale, vi., 284 . The marquis to the bailli, Paris, March I $5,1770$.

2 Ibid., vi., 295. The marquis to the bailli, Paris, April 12, 1770. 


\section{Monsieur de Pierre-Buffière}

something of him. That is the thing, Monsieur le duc, that led me to ask only a commission. I am not ignorant of the disadvantages of those sorts of indefinite positions that are attached to no troop, that are bound, so to speak, to nothing, and give training in nothing; but I see clearly that if my son enters a new corps that will have no control over him, he will be ruined inside of six months. Monsieur le duc, deign to believe a poor father who is neither false nor hard. Furthermore, I am assured that the employment with which he would begin would call for only four months of service, and what am I to do with the other eight?... If you will leave this young man attached to the legion of Lorraine, you will save him; if not, in six months, reckoning from the day of the commission, you may count upon a vacant company. ${ }^{1}$

It is a curious sight, this father standing in the path of his son's advancement, asking less than the government offers, moved by his distrust of his son's unruly and turbulent character. He did not believe that he was yet fit to command and would discipline him still longer that he might save him in the end. Instead of making him a captain and giving him a company to command, the marquis would give him only the commission or title, unattached to any company, while the young man continued his service under Viomenil in the legion of Lorraine. His request was granted. The minister decided to "watch him for another year" and a notice to that effect was sent to Vioménil on the 4 th of July, I770. ${ }^{2}$ The commission of captain was not issued until the following year. Mirabeau returned to France as he had left it, a second lieutenant in the legion of Lorraine.

Whatever may be thought of the wisdom of the

1 La révolution française, $\mathrm{xxix}, 260$.

2Ibid., xxix., $26 \mathrm{I}$. 
marquis's course, his motive was certainly a good one.

In a word [he wrote, explaining to the bailli why he refused the company offered by Choiseul], if I can, I want to save him. He will have a commission of captain in the pocket of his chief, and will be employed on the staff of those legions where one does not have time to breathe. If I ever save him, that will be a fine cure and the scamp will not need to be pushed and will make his way himself. They are going to return to France, and, while ordering him to pass incognito through Provence, I have permitted him to go to Mirabeau to kiss the hand of his uncle. ${ }^{1}$

When Mirabeau landed at Toulon, he was recognised by two old schoolmates, who greeted him at once and by making him known to others rendered an incognito impossible, as all the friends of the family were desirous of paying their respects to him. At least, that is his account of the affair. ${ }^{2}$ Learning that his uncle was at Aix and not at Mirabeau, he decided to present himself at the former place although he had no permission to do so. ${ }^{3}$ The bailli described the meeting to the marquis:

Yesterday evening, dear brother, I was totally surprised. A soldier brought me a note from $M$. de Pierre-Buffière, who asked for an appointment with me. I sent word to him to come.

I was delighted to see him. I do not know whether, as they say, I have a liver for a heart, but mine expanded much when I saw him. I found him ugly, but with a physiognomy that is not bad, and he has, behind the marks

- Correspondance générale, vi., 295. The marquis to the bailli, Paris, April 12, r770.

2 Ibid., vi., 325. The bailli to the marquis, Aix, May $15, \times 770$.

3 Ibid., vi., 328 . The marquis to the bailli, Fleury, May 23, 1770. 
of small-pox and features that have changed much, the air of the late poor count [Louis-Alexandre de Mirabeau], in attitude, gesture, expression, etc. If he is not worse than Nero, he will be better than Marcus Aurelius, for I have never encountered so much intelligence. It made my poor head spin.

He appeared to me to fear you like the provost, but he swore to me that there was nothing that he would not do to please you. I assured him that, as you were the best of men in every way, you surely could not be a bad father. $\mathrm{He}$ acknowledged to me that he had done many foolish things, but he said that he was desperate. He appeared to me to desire to maintain the deference, the regard that he owes his colonel [M. de Vioménil], but he says that he is rough in his speech. He appears to be attached by friendship to his major, whose name I do not recall [the Chevalier de Villereau], and he tells me that this major would like to meet me when he passes here. . . . He appeared to me to be so much afraid of displeasing you that, not wishing to rob him of the respect due to paternal orders, when he asked me where he should lodge, not being able to keep him with me without making him known, I advised him to go to Lambesc and wait for his regiment to pass.

I can assure you that I found him full of repentance for his past faults. He seemed to me to have a sensitive heart. As for intellect, I have spoken to you of it. The devil has not as much.

As we were together for three hours, we talked of many things. He told me that if he could not have chosen the military profession, he would have gone into the navy. $\mathrm{He}$ appeared to me to fear that you did not wish him to serve in the army. I replied that at his age one might easily deceive oneself as to a vocation and that you would never do more than test him, but that you workld not formally oppose his honest tastes.

He had learned that you were coming here. When I told him that my leg was getting better and that I hoped 
to return soon to Mirabeau, he asked if he might come and stay with me during the sojourn of his regiment at SaintEsprit. I should like very much, in fact, to have him visit me there and give him the pleasure of seeing the little Cabris, whom he says he loves with all his heart. I repeat to you, dear brother, you would please me much, if you granted him this permission. He said to me, with an air that it would be difficult to counterfeit, that he did not dare to hope that you would receive him there, but that he would endeavour to merit it. I assure you, moreover, that he reasons very sensibly upon Corsica and everything. I begin to hope much for him, and, if he is good, he will be an excellent man. ${ }^{1}$

I have given at length the bailli's account of his first interview with his nephew that it might be known how young Mirabeau appeared to eyes less prejudiced than those of his father. Whether the bailli formed a just estimate of the young man or not, it is perfectly clear that he was deeply impressed by his nephew's ability and very much attracted by his personality. It is but another example of the seduction that Mirabeau exercised upon the most of those with whom he came in contact. It is not necessary to assume that he won them simply that he might use them; the bailli was a lovable man. Neither is it necessary to assume that his declarations of repentance were not genuine, although the fruits of repentance may have been wanting. The periodically penitent sinner who continues to $\sin$ is not so rare a character that we are forced to regard the tears and regrets of Mirabeau as so many snares for the unwary.

The marquis granted his brother's request, but put

1 Correspondance genterale, vi., 325,326 . The bailli to the marquis, Aix, May $15,1770$. 


\section{Monsieur de Pierre-Buffière}

him on his guard against his nephew. His tone was severe, but not unkindly.

You may well imagine [he wrote] that what you have said to me about this young man gives me very great pleasure. Although a good heart [meaning the bailli's] may be the tool of a dupe, you may always be sure that whatever may be agreeable to you will be agreeable to me and that is a great gain. You have seen him under the most favourable circumstances, for he is seductive, when his head permits him to be; but the test that you are going to submit him to will enable you to see him inside and out. I grant him, then, in my response, permission to go and pay his respects to you, and to remain with you, if you, as well as his superiors, permit him to do so; it being well understood that he will not be there when I arrive, for the more he fears me the less I ought to let him approach me until I am certain that he is able to hold his head in his two hands.

When he has reached that point, I shall permit him to go to Versailles, but not to Paris, for I have sworn that no one of my boys shall go there before he is twenty-five; [the marquis would consider the advisability of sending his son to Versailles as soon as he could be sure that he would not disgrace himself, for he wished to give him an opportunity to take on something of the polish that could be acquired only at court. He had no doubt that he would make his way there for] he could extract oil from a nut. $\mathrm{He}$ has proposed to me a hundred schemes, and in that little corner where I have kept him he has made and unmade, like Castagny, the projects of all those whom he wishes to attach to himself.

Well, he is going to see you and hear you. I pray you repeat to him what I have said to him that omnis homo nullus homo. Have him read the Economiques and then the first two years of the Ephemérides, for I shall send him the others. 
I forgot to tell you that I am very glad that Louise has attracted this fiery spirit, for I count much upon this precocious child, rendered circumspect at an early age by her environment. Talk to him of the Du Saillants. His brother-in-law may have displeased him in doing him a very important service. [The marquis had in mind the part taken by $\mathrm{Du}$ Saillant in the affair at Saintes.] The fact is that all his [Du Saillant's] life he has been one of his most stubborn advocates. ${ }^{1}$

On the 2xst of May, M. de Pierre-Buffière was back at Aix, lodged near the Porte Saint-Louis in the house of the Abbe Castagny, a former man of affairs of the marquis. Thus his incognito was preserved. "Morning and evening," wrote the bailli to his brother, "I go there for my promenade. . . . He promenades with me, dines and sups with the abbé, then works. As soon as my cook, who is at Marseilles on a matter of business, shall have returned, I shall send M. de Pierre-Buffière to Mirabeau." He did not know when his regiment would pass Lambesc.

I repeat to you [went on the bailli], either he is the most skilful persifleur in the world or he will be the best man in Europe for a pope, minister, general or admiral, chancellor, or, perhaps, agriculturalist. You were something at twenty-two years, but not the half, and I, who without, however, being anything great was something of a little thing then, I avow to you without modesty or false vanity, that when I forced from the creoles the statement that I was not a European, I was not worthy to play by the side of him the rôle of Strabo by the side of Democritus.

In the promenade this morning, he read to me the preface to a history of Corsica that he says will embrace only

1 Correspondance générale, vi., 328 . The marquis to the bailli, Fleury, May 23, 1770. 


\section{Monsieur de Pierre-Buffière}

the last forty years, but in which he presents a summary of the history preceding this epoch. I assure you that at twenty-two you could not have done so well, and I at forty-I could not have accomplished the hundredth part.

You know what a level head the Abbe Castagny has. He opened his eyes and then he wept for joy. As for me, this child makes my chest expand. And what leads me to think even better of him is that I find defects in him, and that makes me believe that I have my eyes open.

He told the abbe that he had not been properly handled in his childhood and that the Chevalier de Villereau, the major, had won him by kindness and reasoning and had made him see a new order of things in good conduct. $\mathrm{He}$ added that his uncle could make of him anything he wished. ${ }^{1}$

In support of his opinion of his nephew, the bailli quoted the saying of M. Césaire, who had met Mirabeau at Toulon, that "it is a head that has need of nourishment and of strong nourishment and that will always be bad in small things." Following up this suggestion the bailli added: "So, if you continue to be satisfied with him, it will be necessary to make an effort to advance him, but in something on a large scale. He appears to me to have taken a decided fancy for the navy. . . . Finally, I repeat to you, if he is good, he will be more than excellent; if he is bad, he will be the very devil." 2

Mirabeau remained three days at Aix. During that time, the abbé had been with him thirteen hours a day and the bailli ten. In all this time the bailli assured his brother he had found

only a little vivacity and fire but not a word that did not

${ }_{1}$ Correspondance générale, vi., 330, 331. The bailli to the marquis, Aix, May 2r, I770.

2 Ibid. 
indicate uprightness of heart, strength of genius, elevation of soul, all perhaps with a little exuberance. The abbe pretends that he was ready to weep when this child said to him eagerly, "Alas, if my father would only deign to become acquainted with me! I know that he believes that I have a bad heart, but let him test me." Finally, dear brother, I think it is to my credit that being with him I feel and I felt much gratified to find myself so inferior in intellect, in knowledge, in genius, and finally in all things, to so young. a man. ${ }^{1}$

In conclusion, the bailli requested that, as Mirabeau was required to serve but four months in the year, he be permitted to pass the summer with the brothers at the Chateau de Mirabeau. It would be a good thing, he believed, for both the father and the uncle. The bailli wished to become thoroughly well acquainted with his nephew. It would give the young man an opportunity to work a little and they might judge what he would make some day. ${ }^{2}$

The enthusiasm of the uncle did not affect the father. $\mathrm{He}$ prided himself on thoroughly understanding the case. His reply to his brother contains a criticism of the method employed in Mirabeau's education and, at the close, a word that may explain, in part, the strained relations between father and son.

I see [wrote the marquis] that the big puppets of $M$. de Pierre-Buffière have developed greater powers of endurance than they formerly had. There is just one thing that I do not like at all, and that is that he continues to say that he was not handled properly. I say continues, because he has said that for the last fifteen years, for he argued beauti-

1 Correspondance générale, vi., 334, 335. The bailli to the marquis, Aix, May 22, I770.

2 Ibid. 


\section{Monsieur de Pierre-Buffière}

fully at certain times. Now although you have not followed this thing, you know Poisson and then Sigrais, they reasoned altogether too much; I myself reasoned with him in a manner unique for a father; Lambert, although prouder, reasoned with him in all things; then the good man Bailli d'Aulan with kindness, and finally Viomenil, who is lively, sympathetic, and just the man to win through kindness; all said to me, the one as well as the other, $\mathrm{He}$ is stronger than I am. However that may be, certainly they have never done anything but reason with him. He has or he had the vanity and presumption of Satan.

I began to have some hope for him after the first letter where he used the expression groan over my errors, for up to the present time everybody has been in the wrong where he was concerned; but, by Saint John, don't take his apologies seriously or he will make a dupe of you, and take care, also, if you wish to give him a free rein, that he does not leave your purse empty.

As for myself, Louis-Alexandre [the younger brother of the marquis] educated me, and I shall go slowly in this matter. Furthermore, for sponging on others, he has no superior. You say that he fears me, but he takes one by storm in a manner that always made me dizzy. Not that I do not think that he suppresses still more of this impetuosity, for his head is a mill run by fire and water. His imperturbable audacity would make his fortune if he once overcame his foolishness, but I have no desire to experiment with him, and I never did believe in fathers and sons being comrades. However, as it is just and useful that he should respect you as he ought to, that he may know your power over me, I reply, as you see in the enclosed letter, very much in detail to the one that he wrote me. . . . Furthermore, I have always written to him in this manner without arrogance or affectation, and at all times without complaining of the trouble it made me. . . If you continue and persist in being content with him, I am preparing a great present for you to give to him, it is

vol. I-I5 
to allow him to take our name [no longer to be called M. de Pierre-Buffière]. ${ }^{1}$

It seemed to the marquis, however, that the affair was moving somewhat rapidly.

As to M. de Pierre-Buffière [he wrote a few days later], I would trust you more in that matter than all the world besides, but you will not take it ill if I go more slowly in this thing. It is not necessary that he should go at top speed at the very start. Three months ago, he looked upon it as a great favour that I granted him an allowance. This summer it is enough and a good deal for him to win his uncle; he will not win his father so cheaply. ${ }^{2}$

The bailli had seen but little of his nephew, but so deeply was he impressed by the young man's personality that he was ready "to wager one hundred to one that if he lived he would differ from the greatest men only by position." 3 As proof of his confidence in this judgment, somewhat hastily formed, it must be confessed, he allowed Mirabeau to visit the ancestral chateau on the Durance and to pass several weeks there with the cook of his uncle as his principal associate and practically without surveillance. It may be readily believed that the marquis was startled at this bit of news.

I regret [he wrote] that he has been at Mirabeau without you. I should be very much pleased to know if he has conducted himself modestly there in your absence. I said to him in my letter addressed to Saint-Esprit: "I told you when you left home that you would never see the paternal house until I knew that you had changed. My brother

'Correspondance generale, vi., 332, 334. The marquis to the bailli, May 29, I 770 .

2 Ibid., vi. The marquis to the bailli, Paris, June I, 1770.

3 Ibid., vi., 334. The bailli to the marquis, Aix, May 22, 1770. 
wishes to receive you at Mirabeau; it is the home of his father, it is mine, but remember on entering it, etc." With all men in general, but above all with those who constantly take advantage of you, it is necessary to insist on the details. Do not forget, I beg of you, to have him ask permission of his commandant and above all to learn when his new colonel will arrive, that he may join the corps before he does; for I wish above all things to break him of these incompatibilities. His vanity will have had free play at Mirabeau and his voracious spirit will have found itself at ease with you and enjoyed a full success. It is a great thing, without doubt, to find oneself at ease with people of ability, but it is much more to put those of moderate ability at ease and to be on good terms with them. In a word, vanity is the stumbling-block of this young man.

Your kindness induces you to act before your letters can reach me. However, you are too well acquainted with my heart not to put yourself easily in my place. What better could I desire than to see this extravagant fellow under your hand and tutelage at your own wish? I recommend him to you, then, and abandon him to you as your son for the present. ${ }^{1}$

The bailli was little disturbed by the pessimism of his brother. In answer to the warning to look out for his pocketbook, he replied:

In regard to my purse, as he is at Mirabeau and as I have not given him carte blanche, as my cook, a careful man, is looking after the expenses, which consist in the cost of food and nothing more, I hope that he will not trouble my purse much, and truly it has no need of it. ${ }^{2}$

Meanwhile young Mirabeau was making the ac-

1 Correspondance gênérale, vi. The marquis to the bailli, Paris, June $I, 177^{\circ}$.

2Ibid., vi., 349-35r. The bailli to the marquis, Aix, June 6, 1770. 
quaintance of the estate that had given its name to his most distinguished ancestors, a name that he was to render notorious by his erratic life. A rude, rectangular building of stone, saved from absolute plainness only by the crenelated towers that rise above the roof at the four corners, the Chateau de Mirabeau stands upon the summit of a hill that rises sheer from the Durance on the one side to descend less abruptly on the other to the level of the surrounding country. The situation, good for defence in the Middle Ages, attracts to-day by its commanding view and the quaintness and picturesqueness of its immediate environment. ${ }^{1}$ The barrenness of the rude grey walls is relieved by the dark green of the pines that fill the diminutive walled park before the chateau, by the masses of foliage that shade the road beneath its walls, and by the red roofs and the mighty branches of the trees of the little village that rambles down the hillside.

So intimately are chateau and village related that it is difficult to mark where the one ends and the other begins. The cottages climb the hill to the very walls of the chateau, while the outbuildings of the chateau are in the village, and the narrow road, almost a country lane, that skirts the summit, suddenly, at the turning of a corner, widens into the quaint and unique street of the hamlet.

1 An excellent description of the chateau and of the surrounding country is contained in Loménie, i., $1-6$. During the revolution, the chateau had been pillaged and practically ruined by the villagers, only the four walls being left. It was sold in 1807 by Madame de Cabris, who had inherited it, for one hundred écus to a neighboring farmer. In I 8 I5, while still in a ruined condition, it was purchased for five hundred francs by M. Lucas de Montigny, the adopted son of Mirabeau, who restored it as nearly as possible to the pre-revolutionary condition.-Mouttet, A. G. Lucas de Montigny (Aix, 1895), 5-12. 


\section{Monsieur de Pierre-Buffière}

It is not the castle of a great lord and, at first sight, is somewhat disappointing to the traveller who approaches it by the winding road from the little railway station on a hot afternoon in summer. But during the hours passed in the shade of the summit with the eyes fixed upon distant hills, soft and restful in the afternoon haze, or under the great trees of the village street, surrounded by the quaint houses and even quainter figures in the dress of the south, listening to the accent of Provence, the charm begins to work, and slowly but surely the senses are captivated. Time makes but little change in these out-of-the-way places. As it looks to-day, so, and not much otherwise, the place must have looked when young Mirabeau saw it for the first time a century and a quarter ago.

He remained about three weeks at the chateau. During this time he was never idle. He corresponded with his father and with his uncle. From the letters of the bailli to his brother we learn something of the contents of the letters of the nephew. Whether Mirabeau saw his uncle at all during his residence at the chateau cannot be ascertained from the evidence that we possess; there is nothing to indicate that he did. It is upon the young man's own letters then, for the most part interpreted by his uncle, that the account of his life at Mirabeau rests.

On the 27 th of May, the bailli wrote to the marquis, "He is already there and sends me details on the estate that prove that he has talent." 1 Three days later, he informed his brother that

M. le comte de Pierre-Buffière works like a convict at his

1 Correspondance générale, vi., 34I. The bailli to the marquis, Aix, May 27, $177^{\circ}$. 
task of becoming acquainted with the property at Mirabeau. $\mathrm{He}$ has already sent me volumes on it. $\mathrm{He}$ is an exceedingly rapid writer; neither you nor I can compete with him. He has asked me to keep him at Mirabeau. He remarked to me jokingly that he would be as useful to my legs as my glasses are to my eyes. . . . In eight days he has used up my supply of paper intended for eight months. ${ }^{1}$

Each day the astonishment of the good bailli increased at the sight of the industry of his nephew. "He writes more in a day," he exclaimed, "than you and I together in a month. In four days, four letters of five, four, eight, and three pages. In addition to that, a very detailed description of two or three farmhouses. Furthermore, he has examined the course of the Durance up to Corbières." 2 "He is becoming acquainted with the property as best he can," wrote the bailli, on another occasion. "I say, as best he can, for you know I have an idea that the abbe (Clapier, the farmer) is not very desirous of giving him information, as I doubted very much if he took time to inform me myself, perhaps far from that. I see also that he has formed the same idea of the said abbe that I had." 3

The marquis did not leave his son entirely to the bailli. He not only corresponded with him, but also kept him supplied with economic literature and insisted that he should study it. The letters that the father received from his son did not always please him. It is possible that their tone appeared presumptuous to him. "His last letter, his navy, his provinces, did

1 Correspondance generale, vi., 344. The bailli to the marquis, Aix, May 30, I 770 .

2 Ibid., vi., 346. The bailli to the marquis, June 1,1770 .

3 Ibid., vi., 349. The bailli to the marquis, Aix, June 6, 1770. 
not satisfy me at all," wrote the marquis. "Not that there was anything bifurcate or shocking in the style except the goodness to keep me company, referring to your promenades." The marquis advised his brother to read the letters that he wrote to his son, that he might see the manner in which he managed him, "which does not comport with pedantry, but which warns him against any impropriety between people not contemporaries." 1 It is interesting to observe in the passage just quoted, and in citations previously made, the influence of the training of the marquis upon his theory of education. He had known nothing of father and son living together as comrades, of familiarity between "people not contemporaries," and he would have none of it. He would bring up his son as he had been brought up. His son was twenty-one, but he still treated him like a boy.

It was not to be expected that one so earnestly engaged in propagating a new science would permit his eldest son to grow to manhood ignorant of it. It has already been noted that the marquis had informed the bailli of his wishes in this matter and had set the young man a task. In June he sent a package of material with more definite instructions.

It contains [he wrote to the bailli] my new work intended for you. It is an economic catechism. I told him [Mirabeau] how indispensable it is for him, if he wishes to bearmy name, that he should be thoroughly acquainted with my science, without which he will find himself almost everywhere a rallying-point for people suffocated by the prejudices that surround them and his ignorance will either calumniate me or render him despicable. Order him to apply himself

- Correspondance générale, vi. The marquis to the bailli, Paris, June I, I 77 I. 
to this science and to become thoroughly acquainted with it. You would never believe how it rests the heart and puts the mind at ease. I have added the copy of a little task that I gave his sister [Madame du Saillant], some time ago; it will do for his peripatetic studies. I recommend to you again [he added, referring to some of his son's plans in the letters that he had received] to discourage all the idle speculations of your nephew. ${ }^{1}$

It is difficult to say how much of the science Mirabeau acquired during his residence in Provence. The references of the bailli to the subject are not numerous, and there are reasons for believing that he did not press the matter.

The marquis had planned to pass some time in June at Mont d'Or and had urged the bailli to join him for the sake of the waters. Mirabeau was to be sent back to his regiment,

from which he had enjoyed a sufficiently long and fruitful absence. As to your nephew, that which you may have said to him, that which he may have seen, and the studies that I prescribed for him, will give him occupation for the future. A bottle corked up for twenty-one years ought not to be all at once and entirely opened, for the contents might all run out. The principal thing for this turbulent character-and it is the thing to keep in mind-is that he shall know how to manage and get on well with mediocrities and details. It is by that that we may judge if he wishes to turn over a new leaf, for it is above all the thing that he has the most need of in this world. He wrote to me concerning his work, which shows marks of audacity and of character. I wish to handle him in the right way. You will see that by the enclosed letter. To sum up, I shall

1 Correspondance générale, vi. The marquis to the bailli, Paris, June I, I 77 I. 
have made a tremendous gain this year if he reaches the point of regarding you as his guide and patron. ${ }^{1}$

The method employed by the uncle in dealing with his nephew was the antithesis of that to which the father pinned his faith.

I believed, on seeing this child [explained the bailli], that I ought to let him have his way that I might become better acquainted with him, realising that I am always quick enough to resort to severity. When I found that he was too exalted in his tone, I began to laugh and replied to him coolly, as if I enjoyed hearing him talk extravagantly. I assumed an air of indifference to anything personal and saw him recover his balance without having made him feel the weight of authority, being of the opinion that that of an uncle is found only in the strength of his intellect, the uprightnesss of his heart, the purity of his morals and his example. I have let him know that he is being tested, that his present conduct will decide whether his future condition will be happy or unhappy, and that I, in particular, would be a useful and condescending friend to him, if I saw that his heart is good and that he endeavoured to render himself worthy of you; but that I could be the most severe of judges, if he rendered himself unworthy of you and that surely, in the last case, without emotion and without anger, I would renounce him and would have no further reason to speak of him. ${ }^{2}$

I have managed him [continued the bailli] by means of gentleness, indulgence, and a thousand pleasantries. $\mathrm{He}$ seems to love me much. I remarked to him the other day that, without dictating to him, I would give him a memoir containing matter for reflection concerning his conduct in the future. "Dictate!" he exclaimed: "Oh, my dear uncle,

1 Correspondance générale, vi., 343. The marquis to the bailli, Fleury, June 4, I 770 .

2 Ibid., vi., 349-35I. The bailli to the marquis, Aix, June 6, 1770. 
would that all who dictate to me might be like you. Would they always had been." I believe that the way to deal with characters like that is to win their confidence. ${ }^{1} \mathrm{He}$ is a little hasty in forming judgments [wrote the bailli, at another time]. He remarks to me "I am an ass, I am a tripleheaded ass," and then he concedes the point. Finally I don't say that he possesses a ripe mind, but a very powerful one, and one in which there is much talent. I believe, for I hardly dare to venture a judgment, I believe, I say, that the way to treat him is to reason with him. He gets excited, shouts, and then recovers his balance good-naturedly. He listens to reason. He takes notes upon all that he hears that is new to him. You are, furthermore, very far from being consistent, for you say that you do not wish to see him until he understands you better, and he asks with clasped hands that his father will be kind enough to become acquainted with him. In the midst of it all, I hardly know what to decide unless it be that your will shall pass as law. ${ }^{2}$

It appeared to the bailli a very easy matter to render his nephew presumptuous:

There is so much more danger for him in this regard, as it is impossible that he should not feel a certain superiority on the side of genius, in the presence of almost all those of his age and of many much older. He is not restrained as you are by timidity, for he does not appear to have any of that at all. That head of his is a mill turning out thoughts and ideas, many of which are decidedly new. You will find as I do that the furnace is very hot, but, dear brother, let us not forget his age. If, as I believe, he has a good heart, this verdure will turn into sap. [The metaphors of the bailli convey his meaning very vigorously,

:Correspondance générale, vi., 34I. The bailli to the marquis, Aix, May 27, $177^{\circ}$.

2 Ibid., vi., 346. The bailli to the marquis, Aix, June I, I770. 
even if they are a little mixed.] But it is well [he continued] that he should be within reach of restraint, for, while understanding reason perfectly, he understands nothing but that and suffers horribly when he is forced to submit to any other human restrictions. We carry on a regular correspondence and I moralise jokingly and pleasantly. I believe that he likes me, because, without pedantry and taking him at his word, I said to him that as he wished me to believe that he is good and that he has reformed, I would go on that assumption; that if he deceived me it would be he that would be caught, and that duped once I would be of the opinion of the Turk, that if a person deceived me once it would be his fault, if he deceived me twice, it would be mine. ${ }^{1}$

The marquis had advised his brother to hold up the Du Saillants before his son as models. His attempt to do so brought out some interesting facts that may be of value in considering the relation of Mirabeau to his brother-in-law, a gentleman who is always in the background, speaking kindly of the prodigal, interesting himself in him, and yet seldom, if ever, treated with gratitude by Mirabeau.

Between you and me [replied the bailli], he does not seem to like either Limousin or M. du Saillant. Not that he has not spoken to me of him in a very proper way, but as I am older, I am sharper and I discovered that he was not carried away with him. I felt that I ought not to make him explain himself more clearly. An uncle is a person who, after he is past twenty-one, ought to show some discretion. Castagny got a few words out of him, which, without being explicit, let the old fox see that he was a little fearful that the complaisance and assiduity of his brother-in-law toward his mother [Marquise de Mirabeau] and his grand-

1 Correspondance générale, vi., 355. The bailli to the marquis, Aix, June 10, I 770. 
mother [Madame de Vassan] were a little interested. I avow to you that I myself, who, as a result of being duped, have grown to be distrustful, if I had not the blindest confidence in your judgment, I should have dwelt a little on that idea, that has come to me often and that I suspect has also found lodgment in the head of your son. At least, that is what I suspect, for neither Castagny nor I have been able to make up our minds on the subject, his words only indicating little warmth. ${ }^{1}$

The manner in which the marquis received this response was characteristic.

I looked for prejudice on his part toward his brother-inlaw [wrote he] or something similar to that, but not for this perversion on the side of interest. That is not a trait of our house, dear brother. We have always had larger hearts than that. ${ }^{2}$

The rebuke certainly fell upon the bailli more than upon his nephew, for the good man had committed himself in his letter much more than he had committed Mirabeau.

The bailli was not, however, a novice in the training of young men.

I have noticed everywhere [he remarked in explanation of his success in dealing with his nephew] that young men have confidence in me, and I have seen youngsters in the navy and at Malta, with whom others could do nothing, but whom I have overcome by reasoning mixed with pleasantry. These young people, who saw that it was equanimity and not weakness that saved me from anger, loved me for it and believed in me the more. All that, I say, may have rendered me the dupe of this young man,

1 Correspondance générale, vi., 346. The bailli to the marquis, Aix, June I, 1770.

2 Ibid., vi., 347. The marquis to the bailli, Paris, June 9, 1770. 


\section{Monsieur de Pierre-Buffière}

but I do not believe it. Provided that he sincerely recognised his faults it seems better to me that he has always reasoned about them than that he has avowed them too easily. I have never seen worse subjects than those who readily acknowledge their errors when they are young. That indicates an indifference to the wrong, which is indeed the only truly moral disease that leaves no impression. ${ }^{1}$

The marquis did not wholly approve of his brother's method of "letting the young man have his way" that he might show his character.

As to M. de Pierre-Buffière [he answered], it is true that we ought to let the young dogs run, but the old ones ought not to follow them. They remain behind and with a yelp they bring the whole pack back upon the trail. As to myself, I assume the whole responsibility and if he wishes to do what is right, we shall easily agree and I will give him something to do. But I desire that the task should be mine not because of a pride in a pedantic primogeniture, but because I can set him on the right road, assistance that I always regretted and sought for in my youth, and which did not exist at that time, but which would have taken me a long way if I could have found in my time that which I can furnish to him. ${ }^{2}$

The assistance to which the marquis referred was evidently such as would enable his son to master the principles of the science at an early age and thus open to him a career that had been closed to his father. It will be seen later that he had no desire to make a soldier of the young man. The marquis agreed that his brother had "natural aptitude for directing youth." He had formed this opinion of his ability thirty years

1 Correspondance générale, vi..349-35I. The bailli to the marquis, Aix, June 6, 1770 .

2 Ibid., vi., 347. The marquis to the bailli, Paris, June 9, I 770. 
before, when the bailli had informed him that he had "the maternal penchant for pedantry, and that with that one annoys men that have attained their growth and spoils those that are being formed. However," continued the marquis, "I know that he is right in wishing me to see him, for when he kept himself in hand he put a sort of embargo on your judgment that was very advantageous to him, an operation facilitated, in truth, by the difference you found between the man before you and the man who had been described to you." 1

On the I6th of June, Mirabeau was back in Aix with his uncle. ${ }^{2}$ If we may believe the bailli, he had made a good impression upon all with whom he came in contact on the ancestral estate. The Abbé Clapier, "who, between us," remarked the bailli, "has not a very transcendent spirit, but who would throw himself into a furnace for us and has considerable tact, finds $M$. de Pierre-Buffière young and very lively. But he believes that he has a good heart. He believes that he is presumptuous and I believe so also." 3 The bailli talked with his cook about his nephew. The cook was "a man of the right stamp and very intelligent." He was a hunter and followed the young man everywhere. "I talked to him," wrote the bailli, "confidentially and said to him, a thing that is true, that $M$. de Pierre-Buffière was very lively and petulant. 'Oh, yes, Monsieur,' he replied to me, 'but he is a good boy and has a very good heart. Oh, Monsieur, you

1 Correspondance generale, vi., 352. The marquis to the bailli, Paris, June $14,1770$.

2 Ibid.. vi., 363. The bailli to the marquis, Aix, June 16,1770 : "M. de $P$. Buffière est dans ma chambre dans le moment."

3 Ibid., vi., 357 . The bailli to the marquis, Aix, June Ix, 1770. 
should follow him as I did, if you would see the thousand little things that made me think that he has a good heart.' You may believe," commented the bailli, "that that did not displease me much." ${ }^{1}$ Even the words of the peasants upon the estate were quoted in proof of the widespread reputation for goodness that the young man had made. ${ }^{2}$

When Mirabeau returned to Aix, it had not been decided what should be done with him. Several times the marquis had sent instructions that he should rejoin his regiment, but this did not satisfy the bailli, who was desirous that father and son should meet. The marquis had planned to come to Mirabeau, but it will be remembered that he did not wish to meet his son. Unwilling to leave the young man there in the absence of his brother, the marquis urged the bailli again to meet him at Mont d'Or, taking young Mirabeau with him as far as Saint-Esprit, where he could join his regiment. ${ }^{3}$ The bailli, however, did not wish to go to Mont d'Or, and it may have been for the purpose of attracting his brother that on the I8th of June the marquis proposed that his brother should come and bring his nephew with him. Among the reasons given for this course were that Mirabeau might "become acquainted with his sister and his brother-in-law, and see how much we think of these worthy children," and "that we might talk together about the situation. For,

1 Correspondance générale, vi., $363-366$. The bailli to the marquis, Aix, June $18,1770$.

2 Ibid., vi., 370 . The bailli to the marquis, Aix, June 27, 1770 : “Le brave M. de P. Buffière . . . a laissé à Mirabeau cette réputation de bonté qui m'est revenue par en bas. Les paysans disent, es ben vior mai es bouen, nous fazie amitié en touties; boulegue toujours, mai n'a ger d'ourguei."

3 Ibid., vi., 347. The marquis to the bailli, Paris, June 9, 1770. 
if it is true that he can be trusted and kept under control, there would be other plans to make that he might not lose his time. Finally it is almost as easy to send him back from there to Saint-Esprit as from Mirabeau. These are my reasons that I submit to your examination and decision. . . . It is necessary that you should take the whole thing upon your shoulders, while keeping me advised." 1

On the very day that the marquis made this suggestion to his brother, the bailli was writing to announce the departure of Mirabeau, who had joined his regiment and was at Pont Saint-Esprit. The bailli wished to go to Barège, and as Mirabeau's regiment might pass at any time, he had written to the marquis that if it appeared before he had received any other instructions concerning his nephew, the original orders would be followed. ${ }^{2}$

- During the two or three days that Mirabeau passed with his uncle on his return from the chateau, the good impression, made by their former intercourse and correspondence, seems not to have been changed. A letter written at this time contains proof of the injustice of the attitude of the marquis toward his son.

M. de Pierre-Buffiere is in my room at this moment [wrote the bailli]. I found him very sad over the words that you addressed to him concerning the operations at Mirabeau. But I had absolutely forgotten to tell you that when I sent him to Mirabeau, in order to save him from idleness, I told him to learn all he could about the estate, and he has only done what I told him to do; thus he was not in the wrong.

${ }_{1}$ Correspondance génerale, vi., 360 . The marquis to the bailli, Paris, June 18,1770 .

2 Ibid., vi., $364-366$. The bailli to the marquis, Aix, June 18, 1770. Ibid., vi., 353. The bailli to the marquis, Aix, June 8, 1770. 
. . He was offended because you scolded him for the use of the word little Cabris. You know very well that it is a term of affection, and these children understand one another thoroughly and love one another. You see, dear brother, that I am a little like our poor Abbé Castellane who was, you know, indulgent, and I feel that I am becoming so. Now, I ask of you, in case I do not go to Mont d'Or, if you would be willing that $M$. de Pierre-Buffière pass with me at Mirabeau the time that his regiment remains at Saint-Esprit, naturally with the consent of his superiors.

I want to say to you that this young man is lively, impetuous, and has nearly all the gestures and manners of the late count, his uncle, exaggerated, however. But I believe that his heart is good. He is hot-headed, but I find nothing bad in him. . . . If I had any advice to give you in this regard, it would be to ask you to show him a little, not kindness, but a little diminution of tension.

I do not wish [the bailli wrote, in concluding this letter] to do anything in regard to him except by your wish, for I see that it is not possible for us to understand one another. He displeased you, for example, by doing what I advised him to do, because you thought the idea originated in his own head. Finally, dear brother, I ask of you, if you hear a good report of him, to be willing to relax somewhat the austerity with which you have had reason to treat him. If he causes those reasons to disappear, it seems to me that that ought, at least, to cause the effects to diminish. ${ }^{1}$

It is hardly to be wondered at that the admirers of Mirabeau, who have taken his side against his father, regret that his early training could not have been in the hands of his uncle, and even go so far as to assume that it would have made a different man of him. The historian can hardly assume to pass upon such ques-

1 Correspondance générale, vi., 363 . The bailli to the marquis, Aix, June 16, I 770 .

vol. $I-16$ 
tions. It should not be forgotten, however, that, while Mirabeau remained nearly three months in Provence, his uncle saw but little of him during this time and might with reason be charged with forming premature judgments.

When Mirabeau joined his regiment, the bailli made the acquaintance of the officers and gathered additional evidence concerning the character and conduct of his nephew.

I have, furthermore, seen his major and his adjutant [he wrote], who is a member of the German chapter. Both are chevaliers de St. Louis, ergo not children, and both have an air of decency and military gravity that I have not noticed since my return to France. Not only have they spoken to me about him in a friendly way, although to tell the truth they have not said much about him because he was present, but I observed carefully the manner in which they conducted themselves with him, and it was easy to see that they loved him and esteemed him. Furthermore, the Abbe Castagny has been keeping his ears open and accident furnished him opportunity for talking with officers of the corps and he questioned them about him. "Parbleu, Monsieur," they answered "he is a devilishly lively boy, but he is a good boy who is bright as the devil and, parbleu! a very fine man." The Baron de Lanquier, who knew his name and of his existence, heard him mentioned by his officers. He inquired about him and they made the same response. The baron sought Mirabeau out and greeted him. He was much pleased with the air of respect that he showed for his white hairs. 1

In the same letter, the bailli described his nephew: "He is five feet five inches, rather stout for his age;

1 Correspondance générale, vi., 364,366 . The bailli to the marquis, Aix, June I8, I 770 . 
limbs that appear strong and, in fact, he is very vigorous in his gestures, his attitude, and his movements. $\mathrm{He}$ has much of the manners of our German brother."

The bailli was very desirous that his brother should see his son and treat him with less severity. "Consider well," he urged, "if it would not be worth while for you to become acquainted with him. Allow me to say that rigour may do harm. I do not know whether or not I have allowed myself to be seduced by the love he has shown me, but it seems to me that I did not amount to nearly so much at his age. You know, also, that at his age one may be giddy. He has made the conquest of all that have seen him here, and that is a small, a very small number."1

One man, it is true, had not made a good impression upon Mirabeau and that was the Abbé Clapier. "As I told him," said the bailli, referring to his nephew, "to kill time at Mirabeau in examining the estate he thought that he was doing the right thing in following my advice in earnest, but he noted that the abbé did not endeavour to help him. It entered his head that you were paying well for repairs and that the farmer was profiting by it. Finally the abbé did not make a conquest of him any more than he had of me." 2

The bailli did not accept at once the invitation of his brother to come to Mont d'Or with his nephew.

I see [he answered] that you are counting with certainty upon my coming to Mont d'Or and I tremble to think that that may cause you to change your plan of coming to Mirabeau. Moreover, you give me permission to bring M. de Pierre-Buffière with me, a thing that appears to me

1 Correspondance générale, vi., 364,366 . The bailli to the marquis, Aix, June r 8, I 770 .

2 Ibid. 
important, both because of the benefit that his heart may derive from the visit-for they say he has a good heartand from the action that you may take in the matter of his advancement. . . . If you continue to insist on the journey, it may be that I can make it, but if you could arrange your affairs so as to come to Mirabeau after taking the waters, that would be infinitely better. In this way you could.see your son, your brother, and look after your interests here. ... If If you come, we shall find room for you, your daughter, your son-in-law. I shall invite your son, your daughter, and your other son-in-law, and there you are a patriarch. 1

The bailli did not wish to go to Mont d'Or, he was fearful that the marquis would not come to Mirabeau, and he very much wished the father to meet his son. $\mathrm{He}$ was suffering from an injury to one of his legs-the result of an accident at Malta-and was disinclined to travel; "but I do not wish," he wrote to his brother, "that my leg should cause him to lose the opportunity of throwing himself at your feet. . . . I ask, then, your permission, if I do not go to Mont d'Or and you do not come to Mirabeau, to send M. de Pierre-Buffière to you. . . . I am very desirous that you should see your son. If you cannot come, send word to him to join you, if that is your will." 2

Mirabeau was now at Aix with his uncle. "His eyes fill with tears," reported the bailli, "when he sees that you are not coming." M. and Madame de Cabris were at the same time guests of the bailli. "I have placed this whole joyous band at their ease," he said, "in order that they might find pleasure in being here and

1 Correspondance generale, vi., 370. The bailli to the marquis, Aix, June 27, 1770 .

2 Ibid., vi., 372. The bailli to the marquis, Aix, July 2, 1770. 
in order to know them better. I am making a special study of $M$. de Pierre-Buffière. I believe that his heart is good. He is a rogue and younger than one generally is at his age. His childishness forms a singular contrast with reflections and writings that would appear to be those of Locke." The bailli recalled the fact that when he was of the same age his case was even less hopeful. He criticised, however, the manners of a lieutenant of infantry that his nephew sometimes displayed. "But, on the whole," he added, "I believe that you will have reason to be satisfied with him. He is very sensitive, and says that if you will show some affection for him you will make him happy. I believe that he is ambitious and, to tell the truth, it is peculiar to that age. I have never seen a Bohemian to whom sun, rain, wind, and hail caused less fear. It seems to me that he is very fond of war." 1

It seemed advisable to the bailli that Mirabeau should be with his father for various reasons. The marquis would correct "the little imperfections" in his character. Like all young men of his age he was "inclined to be presumptuous and he thought sometimes to distraction. Your vision is more penetrating than mine," explained the bailli, "and if you were satisfied with him, you could try to do something for him, to advance him or to marry him. He appears to me to desire to do his duty and in that case you could decide what you think he is good for." 2

Well satisfied that his nephew would make a good and a great man, the bailli had already begun to turn over in his mind projects of marriage, being desirous

1 Correspondance générale, vi., 375-380. The bailli to the marquis, Aix, August 7 and 10, $177^{\circ}$.

2 Ibid. 
that the young man should remain in Provence. Mirabeau himself seemed to like that province more than any other, and his uncle thought it "more prudent to follow the tastes of his youth in this matter rather than to make him adapt himself to other ideas." Then too with the bailli at Aix it would be possible to make a good match and keep an eye on the young household in the first few years. ${ }^{1}$

Among the young ladies upon whom the attention of the bailli had been fixed were "the little Castellane," "the little Marignane," Mirabeau's future wife, who was regarded as a "very excellent party," with a prospect of 600,000 francs, and "our little neighbour Peycolle would be a very excellent catch, if I could only destroy that unworthy jaunerie ${ }^{2}$ at Malta, that I regard as the most unworthy of exclusions. . . . If you judge it fitting to establish him in Provence, a matter in which you are too good a father not to consult his tastes, I believe that then it will be necessary for you to overcome the repugnance that you feel for Aix, that is of such a kind that you not only feel it yourself but feel it for others." 3

The bailli did not mention in this letter the "party" that he preferred and whom they were most likely to secure. The Abbe de Grille, whom the marquis, it seems, disliked, had spoken to the bailli of a young lady, "eighteen or nineteen years old, well formed, of good appearance, and of good family." She was an only daughter with the expectation of an income of 25,000 francs. "The attachment that this daughter

${ }_{1}$ Correspondance générale, vi., 367-369. The bailli to the marquis, Aix, June 22, 1770 .

2 Ibid., vi., $375-380$. The bailli to the marquis, Aix, August Io, I770.

3 Ibid. 
has shown for her father, who is a good and gallant man, has edified me much. . . . There is the proposition. If you approve of the idea, that shall be mine only when it is yours, I shall start the ball rolling here. If your reply is favourable, I shall throw out the preliminary remarks and get the lay of the land." 1

Before the bailli received an answer to this proposition, Mirabeau was on his way to meet his father. The marquis had finally yielded to the solicitations of his brother and decided to receive his son on trial. Mirabeau left Aix on the 23d of August for Aigueperse in Limousin, bearing a letter from his uncle to his father. It contained the final judgment of the bailli upon his nephew. "I see nothing bad in his character, very far from it; and as he has an excellent mind, and even what one might truly call genius, something can always be done with that sort of a man." He thought he should be removed from the legion of Lorraine, for, as he was not the right kind of a man to advance in such a regiment, "he ought not to acquire any more of the tone of it, the thing that most calls for correction in his case. ... He appears to me to have a decided taste for war, but does not care for garrison life." He had told the bailli many times that if there were no wars he would not care for the profession. He desired to join the body guard of the king, because of the advantages attached to such a position both in war and in peace. His uncle believed the idea a good one, but he would not press the matter, leaving the decision entirely with the marquis.

"Perhaps you may not find him very strong as an economist," wrote the bailli. "He would have delved

1 Correspondance générale, vi., 375-380. The bailli to the marquis, Aix, August 14, $177^{\circ}$. 
into it as deeply as anybody could, but his sister who was here deprived him of much of the time that he was accustomed to give to study. He had, in addition, his work on Corsica that occupied much of his time. $\mathrm{He}$ is on very friendly terms with Colonel Bottafuoco, colonel of a Corsican regiment of this name, who urged him to prepare a historical sketch of Corsica. To my mind, it is very well done as the work of a man of twenty-one years."

The bailli then explained at some length the views of his nephew on government, views that agreed with his own, but were not in harmony with those of his father. The bailli regarded the feudal order as the only one that could prevent a monarchy from becoming an oriental despotism. "He feels," said the bailli, "that the kind of respect that attaches to families, many of whom hold together and form a tribe, is the only thing that can render considerate a man whom the vilest portion of humanity is constantly assuring of his omnipotence. I believe, furthermore, as he does, that the respect and duties that a certain part of the people owe to the seigneur make themselves felt even by the monarch, and cause him to act considerately." These views of young Mirabeau, as expressed by his uncle, would seem to indicate that his opposition to arbitrary power, at least at the outset, was not necessarily democratic and not necessarily anti-aristocratic. The bailli seemed to realise that these views might not be pleasing to his brother.

It certainly is not necessary to say to you [he remarked] that it would be as ridiculous for a father to demand that the ideas of his children should conform to his own as to ask them to wear his shoes, and, provided that the heart is right, there should be no dispute about tastes. Your son 
fears you, respects you, and loves you, but I believe that I discovered his way of thinking by showing affection for him. I think that without any loss of paternal gravity or authority you may show kindness toward this young man and interest in him. Not only will you know him better, but your lessons will make a more lasting impression, for a son in the presence of his father knows that he can contradict nothing, but he may not be convinced. ${ }^{1}$

Bearing these words of kindly counsel and commendation, Mirabeau left his uncle. His period of probation was not yet over. A returned prodigal, he was once more to enter his father's house, but he had still to convince his father that his uncle had not been deceived, that he was in reality worthy to occupy the place of the eldest son in the household.

In the two chapters devoted to $M$. de Pierre-Buffière, I have endeavoured to bring out in clear relief the characters of the marquis, the bailli, and young Mirabeau. The use of the very language of their letters adds colour to the narrative and brings the reader into direct touch with the writers, enabling him to realise what manner of men they were as no language of mine could have done. The marquis appears lacking in affection, unreasonably distrustful, unsympathetic, and extremely pedantic in his attitude toward his eldest son, but at the same time displays traits the very antithesis of these in his relations with his brother. The personalities of the bailli and of his nephew are largely responsible for the different treatment they received at the hands of the marquis. Self-sacrificing, lovable, high-minded, humane, sympathetic, the bailli is almost an ideal character. Notwithstanding the eulogistic

- Correspondance générale, vi., 375-380. The bailli to the marquis, Aix, August 23, 1770. 
language of his uncle, it is not difficult to see that young Mirabeau possessed a character that might have justified, in some degree, the treatment that he received from his father. He lacked reserve, displaying in his words and actions characteristics that must have reminded the marquis of the boy's mother, just as his face and figure reminded him of the maternal grandfather, or of the unfortunate Louis-Alexandre. It is hardly to be wondered at that he should consider a system of repression and discipline the only one that could make a respectable subject out of his fiery son. The marquis was self-sufficient and so was his son; the marquis wished to be obeyed, to have his dicta accepted without discussion, to keep his son at arm's length, while the son wished to be reasoned with, to be treated as a companion and, realising his own powers at an early age, "had the presumption of Satan." To train such a son would have been a difficult task for any father under the most favourable circumstances; it was an impossible task for a man of the marquis's temperament and training under the unfortunate conditions that have been described in the preceding pages. The statement of the marquis that all those who had had anything to do with the boy's education had found him "too strong for them" should not be overlooked.

The traits of Mirabeau's character have now become fairly well defined. They not only indicate what he is to be, but, taken in connection with the evidence of the preceding pages, they enable us to form a conception of what he has been. He was a young man of marked genius and of uncommon ability. Below the average in height, stout of body and limb, vigorous in gesture, attitude, and action, Mirabeau bore his large head with 
its pockmarked mask in a manner to give outward expression to the confidence that he felt in himself. The officers of his corps had characterised him as "devilishly lively," "a good boy," and "bright as the devil." That he had a good heart was the opinion of all those who knew him during these months in Provence. The bailli was struck by the remarkable combination of childishness and maturity betrayed in the young man's character. He was "hot-headed," "inclined to be presumptuous," "thought sometimes with distraction," and was "very sensitive." $\mathrm{He}$ " had an excellent mind and even what one might truly call genius"; he "understood reason perfectly, but understood nothing but that and suffered horribly when forced to submit to any other human restrictions." $\mathrm{He}$ was ambitious and his vigorous body enabled him to support the strenuous mental application forced upon him by the demands of his restless intellect. Indifferent to "sun, rain, wind, and hail," he was fitted for a soldier's life and was very fond of war. It was the opinion of those who had seen him under fire that he had the making of a great soldier in him, if he would but develop more self-control. His spare hours had been devoted to a mastery of the science and art of war as found in books. Light-heartedness in the incurring of debt and lack of self-restraint in the satisfaction of his passions, two of the distinguishing traits in his character, were not especially marked at this time. He seemed no worse than the majority of the young noblemen of his generation. He had already begun to formulate his ideas upon absolutism, realised the necessity of a check upon the man "whom the vilest portion of humanity is constantly assuring of his omnipotence," and believed that "the feudal order was the only one that could 
prevent a monarchy from becoming an oriental despotism." These, at least, are the views on government that he held in his conversations with the bailli. They were to be modified somewhat in years to come, but Mirabeau never became a democrat, not even when he had developed into an opponent of class privileges. 


\section{CHAPTER XI}

\section{MIRABEAU IN THE CONFIDENCE OF HIS FATHER}

HE journey of Mirabeau to Aigueperse was, in the words of the bailli, "not a little like the return of the Greeks from the siege of Troy." 1 His transit is described by the marquis in picturesque language:

Accidents are made for the impatient. Beyond Roannes a post-horse fell and broke his leg. As he approached him, the horse kicked him in a very tender spot. He was obliged to have himself bled, to rest a while, and then to reach Clermont by coach. But little relieved by his poultices he wished to go on again by post; another fall, vomiting, and finally he called on me for help from St.-Léonard. $\mathrm{He}$ reached here yesterday morning, and to-day he goes to meet Du Saillant and his sister. You know that thumps are necessary for exuberance as dieting is for good health. ${ }^{2}$

His son's impetuosity evidently amused the marquis more than it displeased him.

I received him[he wrote to his brother] with kindness and even with tenderness. I supplied him with such information on persons and things as he had need of, warning him that he who imagines that he sees everybody else is seen by all, and that it is the height of imbecile puberty to peer

1 Correspondance générale, vi., 394. The bailli to the marquis, Mirabeau, September $18,1770$.

${ }^{2}$ Ibid., vi., 38 I. The marquis to the bailli, Aigueperse, September 3, 1770 . 
about as if one were behind a loop-hole; that I would examine him myself and through others, decreasing or increasing the test as I should dare to do so, all for the purpose of knowing if he could be master of himself, a preliminary that was indispensable, in order not to spoil everything, before letting him loose; that not knowing how nor wishing to be a pedant, I desired that my son should live with me as one of the family, that is to say as long as he found it pleasanter there than elsewhere, but if I should see him in peril or in a bad position, I should request him to go elsewhere to await maturity in a place less dangerous. I warned him, however, that there was sufficient time to lose and too much of it, in view of the immensity of the triple career he was to enter upon, if he did not want to fall into excesses. The whole thing, as you may well imagine, preceded by an exordium to the effect that I accepted your guarantee and testimony and believed that I could safely do so.

After that he was very much at home, for he has a great deal of our frankness, vulgarly called indiscretion. . . . $\mathrm{He}$ formed a very just estimate of Caroline [Madame du Saillant], whom I had, furthermore, stuffed with anecdotes that she might not be misled by the sportive and roguish simplicity of his exterior.

The morning after Mirabeau's arrival, and before he set out to meet his sister, the marquis delivered a long homily to his son in which he dwelt upon questions of family policy and the necessity of treating these affairs in a large way, "with nobleness, generosity, and a forgetfulness of petty interests." While he talked, the marquis studied his auditor.

I see [he noted] that my man sticks his nose out or fixes his eyes upon something, or turns the head brusquely, the one a sign of reflection or mental emotion, the other of surprise and disarmament. I followed one up with the 
other, to try the mouth of this fiery animal. Furthermore, suspecting that on his side he was scouting a little, I let myself go and revealed myself more than usual.

I had examined him and listened to him but a short time, when I said to myself: "Now, then, here is another Mirabeau, a chip of the old block," that is to say, a very incommodious being in the first place, and in the second place one of merit on the street. Farewell projects of fortune etc.; it is the fable of the jug of milk. It is not necessary to have a very fine eye to see that service [in the army] is still good for him, indeed even necessary, and three or four at a time, if possible. What the devil can one do with this sanguine exuberance? What field is sufficiently large for him? I am acquainted with nobody but the empress of Russia to whom this man could properly be married. I was on my guard, remembering how the elasticity of the head of my youngest son had concealed a mind without solidity; but with the disadvantage of his ugliness, and of a varnish of pedantry in his manner when he makes compliments and of insincerity when he does not imagine it or know it, this one has a very great advantage over the other one, whose body is obedient only to his passions, while here I see, or think that I see, much of a disposition to contrul the body. There is a long account of an article still very new, but very interesting for us. ${ }^{1}$

The period that follows is one of the most important in the history of Mirabeau's early life. The marquis was favourably impressed with his son's ability and with his good intentions. He overcame, to a large extent, so far as can be judged from the evidence, the unconscious prejudice that he had entertained against him, and for two years the son enjoyed his father's confidence. The marquis is shown in a much more favourable light than

1 Correspondance générale, vi., $3^{81}$. The marquis to the bailli, Aigueperse, September 3, I770. 
any in which he has previously appeared. A detailed treatment of this period will make more intelligible the causes that led to the later rupture between father and son.

I have nothing more to say to you about your nephew [wrote the marquis a few days later] except that I hope that he will be a good child, out of whom will develop a good man; we shall unsoldier him when he has learned something else and appreciated the truth that from Alcibiades to his father, for a man that is at all superior, it is necessary to have a manner for every kind of an occupation, and to drop it at the door on going out; it is well that the soldier should look upon his occupation as the principal one, and almost the only one, as the Capuchins do; but a monk is only a novice who does not know that he should snuffle only in the cloister. Among them, they have asked me to accord him our name, and I have consented, that is to say to you that I am becoming less savage. ${ }^{1}$

A proof of the confidential relations that were establishing themselves between father and son is found at this point in the large register into which the marquis had copied his letters to his brother and the replies of the bailli. The letter just quoted, in which the marquis expressed his good opinion of his son and mentioned the fact that he is now the Comte de Mirabeau, and no longer $M$. de Pierre-Buffière, this letter and the two that follow it are in the handwriting of Mirabeau. ${ }^{2} \mathrm{He}$ had become the amanuensis of his father.

Before he could have learned of the pleasant relations that had established themselves between father and son, the bailli wrote to the marquis advising him

1 Correspondance génerale, vi., 381. The Marquis to the bailli, Aigueperse, September 3, I 770.

2 Ibid. 
to make use of his son in settling his family affairs. "Should you be displeased with this advice," he said, " for I did not fail to detect the little movement of bile under the kind and fraternal words that you wrote me, try M. de Pierre-Buffière, for I know very well that, not being able to see his acts, I could judge of them only by what he wished to do." The bailli had great respect for the opinion of parents concerning their children. A mother had once recommended her son to him, but had said little that was good of the boy. At the time, he had thought her unnatural; he had learned by experience that she had understood the young man's character only too well. "Hence I depend very much upon your paternal eye," he concluded, "without counting the sort of confidence that I have in you as a man solely and independent of the relations between us.",

The family affairs to which the bailli referred were the difficulties between the marquis and the marquise. Their history to the year I 770 has already been traced. The year in which Mirabeau came to Aigueperse was a critical one in the relations of his father and mother. It was the year of the death of Madame de Vassan, his maternal grandmother, who retained in her possession during her life much of the property that had formed the object of the matrimonial speculation of the Marquis de Mirabeau. Madame de Vassan, well advanced in years, and suffering from a malady that presaged an early death, was living with her granddaughter at the Chateau du Saillant in Limousin. Her impending end and the necessity of guarding his interests and the interests of his children, in the property that she would

1 Correspondance générale, vi., 388 . The bailli to the marquis, Mirabeau, September 8, 1770.

vol. $1-17$ 
dispose of by testament, led the marquis to tarry longer in Limousin than he otherwise would have done. The marquise was also in Limousin, the inmate of a convent of Saint-Junien. ${ }^{1}$

The marquis followed the advice of the bailli to make use of his son in his family affairs. Until his departure for Paris in the following year Mirabeau was in constant relations with his mother. Madame de Vassan died the $4^{\text {th }}$ of November, I770. ${ }^{2}$ Mirabeau took his mother to the bedside of the dying woman and accompanied her back to the convent. ${ }^{3}$ The marquis asserts that "the first time he saw his mother, he came back ill because of the violent treatment that he received." 4 His conduct satisfied his father, who remarked that he had "made a fine début in the thorns of domestic life." The marquise, "his furious mother, left Du Saillant at nine o'clock in the evening, the very instant of the death, going to consult lawyers and to begin her follies anew." 5 Madame de Vassan had made a will in favour of her daughter. The usufruct of one of the estates fell to the marquise; the rest of the property fell to the husband and wife together, and consequently was to be administered by the marquis. ${ }^{6}$ It will be remembered that the marquis had agreed, on

2 Loménie, iii., 53-55.

2 Correspondance générale, vi., 40r. The marquis to the bailli, Fleury, November I3, 1770 . In the Lettres originales (iv., 27), Mirabeau refers to the death of his grandmother and to the deep impression that it made upon him: "J'ai eu le spectacle de la mère de ma mère expirante. Je ne connais rien si douleureux. (Je ne l'avais revue depuis l'âge de sept ans qu'en enfance, ainsi je ne lui étais point attaché.)"

3 Ibid., vi., 4r2. The marquis to the bailli, Fleury, November 18, 1770 .

4 Ibid., vi., 40r. The marquis to the bailli, Fleury, November I3, 1770.

s Ibid.

- Loménie, iii., 56; ii., 479. 
the death of his mother-in-law, to increase the allowance of his wife from 6000 to 10,000 francs, assuming that all the revenue from the inherited property would fall to him. The revenue of the marquise had been increased 8000 francs by the will and she demanded in addition the 4000 francs that had been promised her. The marquis was not only unwilling to grant this, but he was fearful that his wife would at once attempt to sell the estate that she held under the title of paraphernal property, that is, property not to be enjoyed in common by husband and wife. ${ }^{1}$

Mirabeau attempted to render his mother reasonable, to induce her to come to terms with the marquis, to prevent her from following any course that might be injurious to the family. The scenes that took place between them were of the most exciting character. On one occasion she discharged a pistol at his head. ${ }^{2}$ Although he reported to his father that "she would never be able to control herself," he confidently promised to make her do whatever was desired. ${ }^{3}$ In these interviews the marquise made the most serious charges against her husband, declaring that he was responsible by his example, by his infidelity, and by the sufferings that he had brought upon her, for all her shortcomings. All these charges, including that of illegitimate children, were faithfully reported by Mirabeau to his father, with the advice that he should be prepared to meet the charges with countercharges. ${ }^{4}$ The marquis was

1 Correspondance générale, vi., 40I. The marquis to the bailli, Fleury, November I3, r 770 ; Loménie, ii., 481.

${ }^{2}$ Loménie, ii., 478 , quotation from a letter of Mirabeau to Boucher, November I 8, I 779 .

${ }^{3}$ Correspondance générale, vi., 4I2. The marquis to the bailli, Fleury, November I8, 1770.

4 Loménie, iii., 58, quotation from a letter to Du Saillant. Mira- 
so well pleased with him that he wrote to the bailli that "he had gauged his mother and was capable of controlling her, a necessary thing, if my colic is not to ruin the family." 1 The bailli rebuked his brother for his language, saying, "You know that one ought not to talk to a son about his mother in such a tone as that." 2

Whether it was solely due to the influence that he was supposed to have with his mother or not, Mirabeau was soon on the most confidential footing with his father. ${ }^{3}$ The letters of the marquis contain convincing proof of the marked change that had taken place in their relations. He dwells with evident pleasure upon the sayings of his son and the little incidents of home life. "Just now," wrote the marquis, "as he was passing

beau gives an account of the charges made by his mother against his father in Lettres originales (iv., 56). The same charges of infidelity are made in the memoir of the marquise against the marquis, quoted by Peuchet, Mémoires sur Mirabeau (4 vols. Paris, 1824), i., 28, 29.

1 Correspondance générale, vi., 412. The marquis to the bailli, Fleury, November $18,1770$.

2 Ibid., vi., 4I9. The bailli to the marquis, Manosque, November 27,1770 .

${ }^{3}$ In the Lettres originales (i., 296), Mirabeau gives the following account of a conversation with his father immediately after reaching Aigueperse: “C'est à vous, mon père, que j' adressai ces paroles une heure après que vous m'eûtes ouverte vos bras paternels; nous étions dans la garenne d'Aigueperse. 'Mon père,' osai-je vous dire, ' accordez à votre fils une grace nécessaire à notre tranquilité mutuelle. Je suis bien jeune; $\mathrm{j}$ 'ai mille défauts; ils se mêlent aux qualités qui les compensent peut-être. Ma sensibilité est excessive. Si je vous vois sombre un instant, si vos regards ne m'annoncent pas toujours la sérénité de votre cœur, je serai désespéré, mais je garderai le silence; le vôtre nécessitera le mien; je me croirai condamné sans être entendu. Daignez donc me parler chaque fois que quelque chose vous aura blessé dans ma conduite; je l'expliquerai ou j'avouerai mon tort; vous serez détrompé ou vous pardonnerez." "He adds that his father promised to do what he asked. 
through the room to join the hunters, he said to me that Luce, my simpleton of a valet, who is a sort of Bertholde, said to him while blacking his boots, "You must acknowledge, Monsieur, that a body is very unfortunate that has to bear a head like that.' "1 Mirabeau had grown much attached to his sister, Madame du Saillant. "I leave them alone," said the marquis, "and so completely alone that often they would not hear God thunder. . . Y Yesterday, I did not go to the table until the dessert. As I entered the room, I heard him say to his sister, the loudest laugher in France, 'Profit by your chance, my girl, for your father will soon be here.' 'I would have you know,' she answered as she kissed me, "that my father does not prevent me from laughing.' " 2

The marquis was as much impressed as his brother had been by the tremendous activity of his son. "I am astonished and terrified," he wrote, "at the amount of work that he accomplishes. He will have to be a country gentleman, in order not to be ruined physically, a man of a national reputation that he be not unworthy of his fathers, a man of the world because of his estate and fortune, a student because of his tastes and talent; . . . add that he has need of a vigorous and continual exercise, without which, there is danger of nephritic colic, and being so young this disease would prove fatal." 3 The reader should keep this last remark in mind. When Mirabeau, confined at Vincennes, is suffering severely from this disease as the result of lack of exercise, the marquis treats the reports of his condition as so many attempts to impose upon his sympathies. He declares that his son is playing the invalid.

\footnotetext{
1 Correspondance générale, vi., 390. The marquis to the bailli, September 25, 1770 . 
The marquis felt the necessity of forming an establishment for his son. He would have liked to settle him in the Limousin. But Mirabeau was "devilishly Provençal, in spite of the fact," complained the marquis, "that I told him and he saw perfectly that my policy was to anchor a new race here in such a manner that it may become indigenous." Because of this situation, he had often been on the point of requesting the bailli to obtain more definite information concerning Mlle. d'Arles. "And then he said to me that what he would like above all things would be to live near me, and as living with me and living in Provence are two contradictory things I called a halt and said to myself, Let us give this green fruit time to ripen."1 A few days later, he took up again the project of a Provençal marriage and was ready to further it.

Although I have answered nothing [he wrote to the bailli] concerning the Abbe de Grille and Mlle. de Biord, I have not looked upon the idea as an ordinary one, both on account of the nature of the proposition and on account of her character. But an honest man wishes to be sure that his merchandise is of good quality and that was my first duty. As to that, I know very well that a revenue of 25,000 francs in Languedoc is worth more to us than forty in Bretagne; and as to this last, there is no duke or peer that would not run after it.

With this in view, I have carefully examined your nephew, now the Comte de M. . . rudis indigestaque moles and finally I believe that I can guarantee that, by means of a few more years under your guidance, he will be an honest man. That is all that is necessary. A woman of good sense and gentle spirit will do the rest. But we have need of you first of all. So I flatter myself that all

${ }^{1}$ Correspondance génerale, vi., 390. The marquis to the bailli, September $25, \times 770$. 


\section{In the Confidence of his Father}

those with whom we may have to do will take our word upon that point. After all, a man who would consent to accept (as son-in-law) one of our blood and not yet twentytwo, could not expect to find him absolutely temperate. So, then, we have surmounted the principal obstacle and, since you think as I do in this matter, I pray you to have the facts and articles that have been presented to you carefully examined and to put this affair on the tapis. The way to handle it would be, I believe, to appear to have entire confidence in the Abbe de Grille, but at the same time to make use of a little sounder and less punctilious head. Castagny is equal to the most important transactions both on account of his personal capacity and on account of his affection for our house.

In case that the thing turns out to be as it has been represented to you, here is what I would do for my son: I will name him for the entails of our house. You know that our grandfather entailed all his property, the recipient to be named, and our great uncle, called the Commandant of Mirabeau, likewise entailed his property to me. I would promise him 200,000 francs. Add to that the property of the young lady and their future and the future of their family would be, I think, assured, for debts are not permitted to reduce the amount of a donation in a marriage contract. As to the gratifications, that is another thing. I am obliged to live, I have lived all my life, for my family. God knows that I am in debt. I can promise only 3000 francs as an allowance for my son, but I will give him more help by other arrangements, if he becomes capable of managing his estates. But I will not touch the dowry, and you know that richer men than I am have married their sons off and taken their dowry. Furthermore, I will not agree to pay anything for maintenance. Finally, I will give to my son and he shall have the promise and the present administration of the large estates, allowing him to have the house furnished and all that there is in it.

There, dear brother, is the carte blanche that I give you. 
It is the result of much very serious rumination that I have given the matter. I might and I ought, perhaps, to wait longer, but in the first place I am forced by domestic affairs to marry my children off quicker than others do, and in the second place, such an opportunity is not easily found again, if the character of the young lady is such as you have described it to me. As to my haste in writing to you, it is because M. de Choiseul has delayed the commission of my son and it would not be decent to send him to the corps muffled up in my name. Now I shall be embarrassed this winter, as I can not show him nor risk him at Paris, apart from the fact that a sedentary life is bad for his health. If this affair should take colour, I shall send him to you straight away, praying you not to risk him in the city. ${ }^{1}$

The marquis recommended secrecy and haste, as he wished to be in Paris in November and before that time he must decide on the winter quarters of his son.

But the troubles of the Marquis de Mirabeau with his eldest son were to have neither so early nor so pleasant a termination. This dream of a brilliant marriage was never realised. The negotiations were suspended. The suspension was due at first to the discovery that Mirabeau had contracted debts while in Provence and later to the revival of the marquis's plan to settle him in Limousin.

The discovery of the debts seems to have made a more profound impression upon the bailli than upon his brother. He had been much pleased with the reception that the marquis had given his son. "I am charmed," he wrote, after having received the letter in which the meeting was described, "that you received him kindly,

${ }_{1}$ Correspondance generale, vi., 392. The marquis to the bailli, Aigueperse, September $30,1770$. 
because I know that it put you yourself very much at your ease and because it will give him confidence in me. I made fun of his fears in regard to you. He did not quite dare to mock openly my feelings of security, but I could see that beneath his mask he believed that I was much too prejudiced in favour of your good heart and your sentiments for him." In a letter of September 5th, Mirabeau had written to his uncle that "he had been deceived." in regard to his father.

I think as you do [went on the bailli] that he is one of us, a chip of the old block, but if you or I had had as little timidity as he has, we would have climbed upon the shoulders of two thirds of our contemporaries before they had guessed that such a thing was possible. Furthermore, as illustrious as was our father, he was not so celebrated as his.

Finally, I am not disturbed by the fact that you instructed him well, but I believe that it would be wise for you to see him manouvre, to let him talk and show what he is, for although very fiery I have noted two things about him. The first is that he restrains himself from time to time by reflection, and the second that he is two men at the same time. When he sees fit to talk reasonably, Cicero is only a fool by the side of him, but immediately he is many times more of a child than it is proper to be at his age.

I believe, furthermore, that it is good for him to be with people older than himself, for he has his pretensions like any other, and when he is with sensible people, that turns him in the direction of good sense. If he were with young people, he would want to distinguish himself in their manner.

As to the marriage, I am not sure that it would not be a sort of bit that he would feel.

There were, however, so many things to be considered 
in that connection, that he agreed with the marquis that it might be well to wait.

After all this, dear brother [wrote the bailli, in the letter already quoted, but evidently at a later date], the Sieur de Pierre-Buffière has had me sounded on the matter of debts, concerning which, in accordance with my plan, I pretend to be ignorant; but from the account, compared with information I have picked up and with the statement of Puymarets, $I$ have discovered and proved that the rogue was romancing and that he did not tell the truth. That is the reef of all the deranged, but for this family, and above all for this individual, I ought to look somewhat carefully into the matter. All that has prevented me from sleeping at night and the result has been, first that I should be guilty of an imprudence approaching a sin to bind at once the lot of this rogue to that of another; second, that I shall let him pass the winter with his brother-in-law and at home where he will be well cared for and I relieved from his thrifty financial methods; third, we would be fools to trouble ourselves so much about future generations; the best thing being that we should live and help others to live, we who know that we would not lie and that, at the end of the account, we are much vexed. It is best to let everything ripen. ${ }^{1}$

In a postscript, added some days later to the letter, the bailli gave a more definite account of the debts. "I know" he wrote, "that he owes Baron de Maltchon, adjutant and captain in the legion, about fifty louis [r 200 francs]." In addition to this, the bailli had taken up a note for several louis for work done for Mirabeau by a man who served Baron de Maltchon as secretary.

1 Correspondance génerale, vi., 394. The bailli to the marquis, Mirabeau, September 18, 1770. 
There, dear brother [said the bailli], are the discoveries that I have made about your son. I ought in justice to him to say to you that he told me that he owed the fifty louis to the baron and I believe that he avowed to me debts to the amount of one hundred louis. I am not certain of this last point. This thing may embarrass you and here is what I wish to say to you: I wrote to-day to this M. Etienne Roux [the bailli enclosed a letter concerning this man, one of the creditors of Mirabeau], at least, I believe that that is his signature, that I was going to forward his letter to my nephew and that I request him to allow me to hear from said nephew, a thing that will take considerable time on account of the slowness of the post in that region. If it seems wise to pay it, I can pay it from the revenue that I receive at Christmas, that is to say, the II 80 francs of M. Etienne. I might also pay the $\mathrm{I} 200$ francs of the baron in a few days, but your son tells me that he has not drawn his allowance and I believe he counts on paying you when he has made you acquainted with the whole matter. ${ }^{1}$

The marquis received this letter before he had despatched the letter in which he had requested his brother to push the negotiations for the marriage of Mirabeau. If he was much affected by what he read, he did not reveal his feelings to his brother. $\mathrm{He}$ persisted in his original purpose of marrying the young man in Provence. "It is true that he is still to be regarded as a thing, will have need of pater familias for some years, and consequently will not be absolutely disposable. In either case, give me an account at once of the situation, for my principal embargo at present is to know what to do with this young man this winter. If the thing takes shape, I shall send him to you without telling him anything about it; if not, I

${ }_{1}$ Correspondance générale, vi., 399. The bailli to the marquis, without date, but evidently written September 25,1770 . 
shall send him, I think, to Nancy to Baron de Vioménil."1

As to the debts, for some time he made no reply to his brother, and when he did finally write the bailli found the letter unintelligible. "You say to me in your own words," complained the bailli, "that you would do me and him the greatest wrong in the world by liberating him from his debts. That leads me to think that you do not wish me to pay M. Etienne Roux. At the end of the letter, you say in regard to M. Etienne, 'If you pay him, that will go upon my account and afterwards upon the allowance of the young man.' This phrase makes me think that I am to pay this M. Etienne. Tell me what you want me to do in this matter." 2

It was evidently the intention of the marquis to teach his son a lesson by forcing him to spare from his allowance the sum necessary to pay his debts. Du Saillant undertook to act as a mediator between Mirabeau and his father. "When Du Saillant broached the subject of the debts to me," wrote the marquis to the bailli, "I recommended the reply that I had been blown up with all my money. ... And to say in addition that I would not talk about it; thereupon it was requested that their brother might pass the winter with them without any expense to himself." To that the marquis agreed, as it would relieve his purse and at the same time have a good moral effect upon the offender. He agreed so much the more readily as he did not know what to do."All my work, just begun,

1 Correspondance générale, vi., 392. The marquis to the bailli, Aigueperse, September 30, 1770.

2 Ibid., vi., 406. The bailli to the marquis, Mirabeau, October 23,1770 . 
was overthrown." 1 He recalled the instructions that had been given to the bailli and the negotiations in Provence were suspended.

I have treated at length this apparently trivial matter of the debts because it furnishes very valuable evidence of the kindly attitude of the marquis toward his son at this time. It will be recalled how violently he wrote concerning his son's debts at the time of the young man's release from the Ile de Ré. This episode does not seem to have irritated him unduly nor do the relations with his son appear to have been sensibly modified by it. It is possible that the smallness of the debt, the possibilty of paying it out of his son's allowance, and the free entertainment offered for the winter by the Du Saillants may furnish some explanation of the unusual treatment that Mirabeau met with at the hands of his father. The fact that the son was likely to be useful to him in the thorny negotiations with his wife was probably not without weight, and the statement made to the bailli that his son " had gauged his mother and is capable of making her do as he wishes, a thing that is necessary if my colic is not to destroy the family," would seem to indicate that he had the greatest confidence in the powers of his son.

There is, however, some evidence that the marquis was not wholly displeased with the abandonment of the negotiations in Provence. As I have already stated, his plan was to settle one son in Limousin. The marquis did not love Provence and Aix was especially distasteful to him. ${ }^{2}$ His eldest son was attached to

'Correspondance générale, vi., 412. The marquis to the bailli, Fleury, November i 8, I 770 .

2 "La répugnance que tu as pour Aix et qui est de sorte que non seulement tu la sens pour toi-même, mais encore pour les autres." -Ibid., vi, 375. The bailli to the marquis, Aix, August ro, r770. 
the old family estate, and his father evidently saw the force of the opinion advanced by his brother that the young man should be allowed to follow his tastes. All this seems to be made clear by the letter written to the bailli after the abandonment of the project of marriage in Provence:

I desire only the happiness of my children. That is all that I have in mind. Seeing that he is hard-bitted, making a curb necessary, fond to excess of Mirabeau, displeased with Limousin in September, thinking only of the Cabris, although very affectionate toward his sister Du Saillant, I thought that I would make this man happy by settling him and making a "Seigneur meridional" of him with an income, between himself and his wife, of 70,000 francs. I would leave to my younger son all the debts, with Bignon, my house, etc. I would get his mother to adopt him and I would give him to my poor Limousins, who have need of a lord and master. Their devotion, shown by presents, by a continual recourse to me in all their affairs, by obedience to the least word, and a thousand other qualities that impose duties upon them-all this warms my heart as much as the Provençal pride, slander, and animosity rend it. ${ }^{1}$

This arrangement seemed to have been rendered impossible, temporarily at least, by the discovery of Mirabeau's debts.

That the marquis was not angry with his son is clear from the tone of the letter in which he announced the suspension of negotiations. The language is moderate and his son is referred to in the most considerate terms. Mirabeau had been present during the severe sickness of one of the children of his sister, Madame du Saillant. "He rejoined me at Brie," wrote the marquis. "I found a man absolutely changed in three days. His

${ }^{1}$ Correspondance générale, vi., 4 r2. The marquis to the bailli, Fleury, November 18,1770 . 


\section{In the Confidence of his Father}

heart has need of affection. This really beautiful little family had touched it. He loved them all, he was like a true Limousin."1

Mirabeau continued to visit his mother from time to time in his endeavours to bring about a rational settlement of the family affairs. The interviews were usually stormy, the marquise giving way to bursts of passion that so affected her son that he left her "sick and depressed." 2 The marquis appreciated his efforts and sympathised with him in his sufferings. "My poor son," he remarked, " has not made his début on white bread, and I do not think that it took him long to discover that I am of some use to him." 3 He declared that he had engaged in a number of undertakings, "excited by the pleasure of seeing a son that will be a man." He talked confidentially to this son of his great dreams "that embraced generations and the foundation of a dynasty." Mirabeau made note of these "axioms" and "principles" laid down by his father, recalled them when they had been forgotten, and flattered his father by referring to his brilliant sayings as "flashes of lightning." 4 The evidence gives us the merest glimpses, and the most tantalising glimpses, of the perfect understanding that seems to have been established between the two in these few weeks passed together in Limousin.

Judging from the course that the marquis now followed, it is clear that he had returned to his old plan

1 Correspondance générale, vi., 4 42 . The marquis to the bailli, Fleury, November I8, I 770 .

2 Ibid.

I Ibid., vi., 40I. The marquis to the bailli, Fleury, November I 3,1770 .

Ibid., vi., 4I2. The marquis to the bailli, Fleury, November 18, 1770. 
of establishing his eldest son in Limousin. The country was not an attractive one. The land was largely given over to pasture or covered with groves of chestnut trees. Farming, only an accessory to pasturage, was carried on by metayers. Goats' milk and chestnuts formed the food of a large part of the inhabitants. The goats devoured the hedges, the bushes, the enclosures and the trees, but the destruction of the goats as a nuisance meant the starvation of the peasants. ${ }^{1}$ The marquis had attempted to check the increase of the number of animals on his estates in Provence, but shortly after the arrival of Mirabeau at Aigueperse, he called his father's attention to the fact that they were again becoming a pest. The marquis exclaimed: "It would not be just that while here, resisting the sobs of these poor families on their knees before me, I have these destructive animals killed in a country all covered with woods, I should tolerate them elsewhere where they destroy beyond remedy." 2 This year, the peasants were suffering from lack of food, and the marquis, who had taken measures to supply the needy and to furnish employment to those who could work, placed his son in charge of these undertakings. He hoped, in this manner, to interest him in the country and people.

"I have purchased thirty quintals of rice," he wrote to his brother, "and I am going to furnish work for these poor people; my son knows that I intend that he shall make his début here as a man. He already has his orders. $\mathrm{He}$ is to eat at the head of their enormous

1 Montigny, Mémoires de Mirabeau, i., 394-397. An article from the Ephemerides (vol. ii., Iro-I9I, Paris, I77I) is reprinted by $M$. de Montigny as an appendix to his first volume.

2 Correspondance générale, vi., 390. The marquis to the bailli, Aigueperse (?), September 25, 1770. 


\section{In the Confidence of his Father}

table, live upon the same food, encourage them, soothe them, etc., and as you know that one becomes attached to the work of one's hand, you can understand that he will think no more of the imperfections of Limousin, especially as these establishments are truly magnificent." The marquis noted that as his son saw the respect paid to him in the country, as he realised the splendid opportunity that offered itself for founding a house, he began to display some of the enthusiasm that had given birth to the dreams of his father. The conclusion of the marquis was that "he has now had too much of a taste of Limousin to voluntarily give up this undertaking." 1

From Provence, the bailli followed with interest the conduct of his nephew. The affair of the debts had seemingly been forgotten. He learned with satisfaction that Mirabeau had entirely changed his opinion of his brother-in-law, Du Saillant, for the bailli had warned his nephew not to be hasty in forming unfavourable opinions of others. ${ }^{2}$ He related at length to his brother an ambitious scheme of Mirabeau's to make his uncle grand master of the Order of Malta. The bailli treated the suggestion in a manner that proved that he was flattered by it. He believed that Mirabeau was actuated in the affair by the desire to see his house rendered illustrious. The young man had even discussed the matter with members of the order and was enthusiastic over the prospects of success. It was but another example of his readiness to plan for everybody, that has already been noted by his father.

1 Correspondance générale, vi., 4 I2. The marquis to the bailli, Fleury, November 18, I 770 .

2 Ibid., vi., 4 9 . The bailli to the marquis, Manosque, November 27,1770 .

voL. $1-18$ 
There is no evidence that the father ever considered the matter seriously, although it was referred to at length in three different letters by the bailli. ${ }^{1}$

The marquis had returned to Paris in November, leaving his son as his representative in Limousin, while Poisson was steward of the estates. ${ }^{2} \mathrm{He}$ had been urged to call Mirabeau to Paris, but he wished him to make his début in Limousin and was unwilling to present him at court until he had received a commission as captain. The marquis was "chanting his praises" and he would lose no time by the delay. Those who advised bringing him at once to Paris "were not acquainted with his exuberance, with that infantile credulity that rendered him a martyr of all his opinions and disdainful of those opposed to his. Having prematurely developed into manhood," wrote his father, "he arrives in a country where the public, having neither the time nor the taste for second editions, forms a false or an unfavourable opinion of him. Time has already improved him in so many ways that I hope much from it, especially as I know that he is in good hands." 3

Mirabeau had seemingly entered heartily into the work that had fallen to him at Pierre-Buffière. As he was about to leave for his task, he wrote to his uncle: "I go there even with a sort of pleasure, this work being truly charitable in the sense of the ami des hommes, and above all in the spirit of my father, whom I cherish and respect more every day." 4 The bailli

1 Correspondance générale, vi., 419, 427, 431. The bailli to the marquis, Manosque, November 27 , December $3,18,1770$.

2 This is clear from the dates of the letters.

3 Correspondance générale, vi., $42 \mathrm{I}$. The marquis to the bailli, Paris, December 7, 1770.

Ibid., vi., 427. The bailli to the marquis, Manosque, December 3, 1770 . 
was inclined to shake his head over this experiment of making a country gentleman of his nephew. He repeatedly urged upon his brother the advisability of securing a commission for him. He warned the marquis of the danger of spoiling fruit by trying to ripen it too early. His plan was to place the young man in the gardes du corps, thus making it possible for him to enter either the military or the diplomatic service. "I see with pleasure," he concluded, "his rational submission to your wishes, but this submission cannot take the place of inclination and without inclination one cannot do anything of any value." Although he saw that his brother intended to establish his "future race" in Limousin rather than in Provence, and although he looked upon the plan as feasible, yet he believed that Mirabeau's tastes should be consulted. It was his opinion that a young man of his mental activity would be satisfied neither in Limousin nor in Provence. If he should finally decide in favour of Limousin, the bailli advised his brother to dispose of all his property in Provence except that in Marseilles. ${ }^{1}$

The marquis denied that he was more of a Limousin than a Provençal:

We have a double task in Limousin, since, as I wrote my son, when I had seen that he was worthy of confidence, that no one disputed anything with us in Provence, while here there was a heritage to win. The youngster felt that his pride was touched. He has just established my court of prud'hommes, a thing that I regarded as pretty nearly impossible; all suppleness, frankness, activity, employing the curés, filling everybody with enthusiasm; imagine that there are very well-to-do gentlemen among those elected

${ }^{1}$ Correspondance générale, vi., 436 . The bailli to the marquis, Manosque, December 29, r 770. 
by the parishes. Then, for all the other great affairs that have only been begun this summer, the settlement of accounts, everything, in fact. He is the demon of things impossible. At four o'clock in the morning, on the first of January, on horseback in those bogs and mountains, and on receiving my benedictions, his heart has grown light within him and he said, "I shall have a good year." I know very well that his is a mind to be occupied and not exercised. The youngster performs his tasks well.

He assured his brother his intention was not and had not been to keep his son secluded in Limousin, but to bring him to Paris as soon as he could secure a commission for him. "It is my dream that the product of my fine ideas and my good will in Limousin shall fall upon his head, for he is going to be the agent of other services that I am about to render to Provence also. I count, everything considered, that he will be here in Lent." 1

The council of prud'hommes established by the marquis in his barony through the agency of his son was a wise institution and one that naturally appealed to the heart of a man who announced himself with pride a lover of men. The council, as the marquis conceived it, was to consist of eight men, one for each parish, elected by the residents in the parishes. It would meet once each month, of a Sunday, at the Chateau of Aigueperse and endeavour to adjust amicably and without expense all cases in dispute that were voluntarily submitted to it by both parties. If either of the parties refused to accept the decision, and attempted to get the better of the other by the chicanery of the law, the marquis promised financial assistance to the per-

1 Correspondance génerale, vi., 440. The marquis to the bailli, Paris, January $1 x, 177 \mathrm{I}$. 
secuted party. When he left for Paris, the plan was in the rough and he intrusted the further development and execution of it to his son, assisted by Poisson.

For the first time the evidence is full enough to enable us to follow young Mirabeau in the execution of a task that his father had looked upon as "well-nigh impossible" of accomplishment. ${ }^{1}$ After having worked out his plan in detail he laid it before Poisson, who "found it good." Poisson suggested the addition of a notary to the tribunal, who could put the decisions in legal form, and that the intendant should be notified before anything was done. Mirabeau adopted the first suggestion, but not the last. It was not the intention of his father, he argued, to interfere with the administration of justice. "The tribunal was, in reality, only a friendly conference on the affairs of your parishes," he wrote to his father, "and no one could take it ill if you or your confidential substitute should talk with your peasants about their affairs." The plan being formulated, Mirabeau prepared a letter to the cures of the eight parishes asking their assistance. The nature of the tribunal was explained to them and they were requested to explain it to the peasants at the

1 Montigny, Mémoires de Mirabeau, i., 398-433. The material consists of: (I) Extrait d'une lettre de $M$. le comte de Mirabeau à $M$. le marquis de Mirabeau (December 20, 1770); (2) Avis envoyé d̀ $M M$. les curés; (3) Extrait d'une autre lettre (January I, I $77 \mathrm{I}$ ) de $M$. le comte de Mirabeau à $M$. Le marquis de Mirabeau; (4) Lettre de $M$. le marquis de Mirabeau à MM. les Prud'hommes (January 20, I 77 I); (5) Extrait de la lettre de $M$. le comte de Mirabeau à $M$. le marquis de Mirabeau (February 4, 1771); (6) Extrait des registres du bureau de conciliation, installé le 3 fevrier $177 \mathrm{I}$, sous l'autorité de $M$. le marquis de Mirabeau, tenu par les Prud'hommes de sa baronnie de P. B.; (7) Discours prononcé le 3 fevrier I $77 \mathrm{I}$, by Poisson; (8) Réplique de $M$. le comte de M.; (9) Lettre de M. Poisson à M. le marquis de Mirabeau (February 7, I77I); Réponse de $M$. le marquis à M. Poisson (February 16,1771 ). 
close of the mass, and to arouse their interest in it by making clear the benefits that they would derive from it. Before the elections, that were to take place the first of January, Mirabeau invited the curés and the seignorial judges of the barony to meet him at the Chateau of Aigueperse, on the thirty-first of December, to discuss the matter. His invitation was accepted by all the curés but those of two parishes out of eight, and they "applauded the utility of the project." A certain advocate opposed the measure. "I refuted him publicly," wrote Mirabeau to his father, "honestly, patiently, and kindly, wishing, as I said, to be assisted by the wisdom of all, that the project might succeed. But when I had him in a corner, I attacked him personally, saying, very dryly, that it appeared very singular to me that he should draw upon his imagination to such an extent to find reasons for opposing your desires."

The object of the elections, as announced in the circular letter to the curés, was " to have chosen in each parish, by a majority vote, a man of good reputation. M. le Marquis de Mirabeau requests, furthermore, that he may be the father of a family, a thing that will attach him more closely to the interests of the public, and of mature age, since then he will be better informed concerning the circumstances that ought to influence decisions in cases of arbitration." The curés were requested to assist at the elections, but Mirabeau did not leave them without guidance. He sent persons in whom he had confidence to each of the six parishes that had been represented at the meeting of December 3 Ist, "to follow the elections of the prud'hommes." He himself "took the rest of the burden," or, in other words, he went to the two parishes that had not been 
represented and that might, by their opposition, ruin the whole undertaking.

I left the next day at four o'clock in the morning [wrote Mirabeau to his father] for Saint-Hilaire de Bonneval. I arrived an hour and a half before the parish mass. There I encountered the cure, who, I assure you, at once made a conquest of me. Imagine an old man with gray hair, curé, without a vicar, of more than six hundred communicants and provided, according to the avowal of his fellow-priests, with the worst benefice in the world, to whom a better benefice has been offered several times, but who has never been willing to leave his flock. All his parishioners bless him, and it is from them that I learned what I have told you. The cure was in sympathy with the plan, had just the man for an arbitrator, but wished the election postponed-a mere form he said, as all the parish would vote for this man, who had for some time arbitrated all the quarrels in the parish-until Sunday, as nearly all his people were at the fair.

Mirabeau readily agreed to the postponement. The dissatisfaction that existed in this parish, he learned from the cure, had been due to the killing of four goats by the guards of the marquis. The peasants were in a state of revolt. The curé agreed that "it is a good thing to destroy the goats; they have eaten more of my cabbages and hedges than they have left; and furthermore there is a decree of the parliament of Bordeaux that is formal concerning this matter; but there are unhappy beings who have no other means of nourishing their children, and I am acquainted with parishioners who would fight to the death if any one touched their goats." He then called a poor woman who had two infants. "She was enceinte, could give them no nourishment, had not a square foot of land, and her 
sister was nursing one of the children. Two of the goats of this unhappy woman had been killed. Oh! that touched me." Mirabeau asked the price of the goats and gave the woman twelve livres. He then explained that his father would furnish milk to those who needed it, but there must be no goats. "Oh! if you could have seen this poor curé weep and throw his arms around my neck, then go to this woman shaking his arm and his head, and then, not being able to say anything, as if he were choking, come back again to me, that would have touched you." Another woman, who had lost a goat and had been obliged to beg, he engaged as a servant for the chateau and her son was to be employed as cow-herd. "The village was afire in a moment on account of those two acts; if you had seen as I did these villagers, lately on the point of revolt, touching their hats with smiling faces, you would have said, as I did, There are three hours well spent."

From Saint-Hilaire, Mirabeau pushed on to Boisseil, where an excellent man was elected in the midst of the enthusiasm of the community. At the end of the day, three parishes had not yet elected their representatives, but the affair promised well. "You see, my dear father," he wrote to the marquis, "the task is nearly completed. I have felt some scruples because our arbitrators were not peasants; but after a little reflection I said to myself, As a matter of fact, this election has been free and unanimous. Why deprive these gentlemen of the reward for the confidence that they have been able to inspire in others? Was not this confidence edifying? Will not this tribunal be more imposing with three of its members seigneurs and men of distinction?" 


\section{In the Confidence of his Father}

On the third of February, the bureau of conciliation, as it was officially called, was installed at the Chateau of Aigueperse. After the celebration of the mass in the chapel, the prud'hommes, with Mirabeau at their head, accompanied by guards in ceremonial dress, marched to the grand salon of the chateau, where they seated themselves around a long table covered with green cloth, saluting as they did so to right and left, according to custom. As the representative of his father, Mirabeau read an address from the marquis to the prud'hommes-elect. He assured them that he would rather be present in their honourable assembly than at a royal banquet. "As to kings, although they may be chosen by the hand of God, and for that reason very respectable, the secrets of heaven are, however, impenetrable in the choice of sovereigns; while you were chosen by the people, by those who see you every day, who with one voice have declared that you are prud'hommes, that is, good men, and have submitted to you their interests and their passions." The marquis's letter contained an exposition of the golden rule after the manner of the Ami des hommes. "We can do nothing without the aid of each other," he exclaimed. Even our daily bread cannot be obtained without the succour of our brothers. The king himself, the anointed of the Lord, receives from the hands of labourers . . . the bread necessary to-day to give him strength to rule to-morrow." In the midst of a description of the benefits that the tribunal would confer upon the peasant, the marquis exclaimed parenthetically, "God knows whether I ever regarded a poor labourer other than as my equal, and even as my master, if suddenly it should please Providence to exchange our lots." He concluded with a picture of 
the future of the tribunal, referred to the parts that he himself, his son, and Poisson had had in its formation. "When I read your letter," wrote Mirabeau, "and reached this phrase, and the children of your children sitting in these seats, I read it with all the simplicity and nobility that I could put into an expression so kind and paternal, and I saw clearly a change in the faces of our prud'hommes; tears filled their eyes. I confess that I choked and was obliged to stop to clear my throat."

Poisson, who had been selected by the marquis to preside over the tribunal, addressed to the count a "pompous discourse," to which Mirabeau replied briefly, avoiding all oratorical effects, pointing out the voluntary character of the arbitration and the necessity of referring the affairs that arose to the prud'homme of the parish concerned, that an examination might be made and a report presented to the tribunal. The business-like brevity of his son's remarks pleased the marquis, "so much the more as laconicism was not what we formerly feared in his case."

The tribunal then rose and passed into the council chamber, where it deliberated behind closed doors upon some half-dozen cases that were presented to it. Among these was one against the mine in which the marquis was interested. The complaint was brought by a peasant who charged that his property had been damaged by carts passing to and from the mine. The decision was unfavourable to the marquis. "The audience closed at half past one and was followed by a very attractive and enjoyable repast; permission was asked to drink to the health of the founder of the bureau, that never merited more the title of conciliation than at the end of the repast, when everybody embraced 
everybody else in the most fraternal manner, pell-mell to right and to left, and reciprocally gave expression to the warmest protestations of friendship."

After dinner, the tribunal held another session. The cases that were presented were referred to the prud'hommes concerned with instructions to report upon them at the next meeting. Thus closed the first meeting of the bureau of conciliation of the barony of Pierre-Buffière.

The tribunal seems to have worked successfully as long as the estate was administered by the marquis. In $\mathrm{I}_{7} 8 \mathrm{r}$, by a decision of the courts, the property passed into the hands of his wife and the existence of the tribunal was abruptly ended.

The opportunity offered by this episode to observe Mirabeau at work at the age of twenty-one would seem to prove that both his uncle and his father were justified in the estimate that they had formed of his energy and ability. The conception of a plan, the choice of methods of execution, skill in dealing with men, untiring application to the object in hand, oratorical talent, keen appreciation of what needed to be said and how to say it-all of these characteristics of the mature man, the leader of the national assembly, are already present in a marked degree in the young organiser of the bureau of conciliation. The skill displayed by Mirabeau during the latter years of his life in dealing with men and affairs was not improvised. He possessed a natural talent for such matters and he cultivated it untiringly from his youth up.

The marquis was charmed with the success of his son and praised him without reserve. He was pleased with his letters, that "went straight to the point," were "devoid of pathos," and "full of warmth that goes to 
the heart." 1 In later years, Mirabeau referred to the "two hundred letters" that he had received from his father, "in which he treated me as a cherished son, as an esteemed councilor, as a useful and necessary co-operator." 2 There can be no doubt of the perfect understanding that existed between the two. Curiously enough, at the moment when the eldest was in favour, Boniface was temporarily in disgrace. 3 The shortcomings of his younger son amused the marquis more than they irritated him, and the portrait that he drew of the boy contains no trace of the bitterness that marked in earlier and later years almost every reference to the elder brother. Desirous of going to Paris, Mirabeau attempted to influence the action of his father through his entourage. ${ }^{4}$ He sent to him the mémoire that the bailli had had prepared for the guidance of his nephew while the young man was at Mirabeau. ${ }^{5}$ These efforts were hardly necessary. The marquis

1 Correspondance générale, vi., 434. The marquis to the bailli, Paris, December 28, 1770 .

2 Lettres originales de Mirabeau, i., 189.

3 "Boniface est encore en disgrace et sans souci comme du cum spiritu tuo de la femme servante la messe; . . . il a une attitude et une mémoire rare et dit après tout le monde sait cela. Le meilleur homme de la terre, bouffon de sang froid, prompt à donner des coups de pied dans le ventre à ses maîtres et à leur pardonner. Un corps de fer, sans souci, plein d'esprit, rond comme un poids et surtout bon cœur et bon diable. Voilà l'homme."-Correspondance générale, vi., 454. The marquis to the bailli, Paris, February 4. I77.

4 Ibid., v., 434. The marquis to the bailli, Paris, December 28 , 1770. The marquis was urged by two friends in Limousin to call his son to Paris. It afterwards transpired that the reason for urging this action was the fear that Mirabeau would marry the young woman of Saintes.-Ibid., ix., 57, Mémoire of the marquis of December, 1778 .

s Ibid., vi., 447,470. The marquis to the bailli, Paris, January 28, I 77 I; the bailli to the marquis, Manosque, February I 5, I 77 I. 
realised that his son ought to be seen in his company that it might not be believed that he was in disgrace, but he was unwilling that he should come to Paris before he had received his commission as captain. $\mathrm{He}$ would thus escape congratulations, "that, in a certain sense, would be disgraceful at his age, for a promotion like that."1

In January of this same year, the marquis had written to the Minister of War, the Marquis de Monteynard, asking that the commission be forwarded. The letter contains valuable evidence of the complete change that had taken place in a few months in the attitude of the marquis toward his son.

Permit me, Monsieur, to have the honour to ask of you the forwarding of the commission of captain à la suite des dragons for my son. I have reason to believe that this advancement was accorded and is dependent at present only upon a few minutes' work on the part of the minister. Although assuming that the request is just, I have reason to think that the lively interest taken in it by Mme. la Duchesse de Choiseul would be a recommendation in your eyes; you are too good a judge of the fitness of a request, that I should fear to repeat to you here the reasons that have influenced me in the choice of a career for him. My son was born with much talent and ardour. His too great vivacity has obliged me to hold him back, and during the four years that he has been in the service it was my wish that he should be connected with a corps in which the discipline was severe and where his pranks would have no influence on his advancement. With this view, after he had passed through the regimental school of the Berri-Cavalerie, I had him attached to the Legion of Lorraine. M. le baron de Vioménil placed him at the head of the chasseurs; he

1 Correspondance générale, vi., 434. The marquis to the bailli, Paris, Dezember 28, 177 I. 
appeared to be satisfied with his service and with his zeal for the profession and urged, on his return from Corsica, that I should make the first request [for promotion] for my son. On his return to France, he passed some time with my brother, a good judge of heads of that age, who was satisfied with him and engaged me to allow him to join me in the province where I then was; I was surprised at his powers of application and I found him at last worthy to be acknowledged.

The marquis had asked of Choiseul that his son might remain with the legion of Lorraine, "where he would be under the influence of a M. de Villereau, who saved him for me, whom I do not know, but for whom my son has conceived both respect and confidence." The favor had been granted and the commission was being drawn up when the change of ministry took place. It was customary not to interfere with matters of a previous ministry that were in this stage. "My son, Monsieur," concluded the marquis, "is in his twentysecond year; I venture to assure you that he means well and to promise you that he will be talented." 1

The commission was granted January 23, I77I. In the report that accompanies it, it is stated that Vioménil,

the former colonel of the Legion of Lorraine, had particularly interested himself in the affair out of regard for M. de Mirabeau, whose career he had never ceased to follow. $\mathrm{He}$ observes that this young man, twenty years of age, is bright and well informed; that he served in Corsica with the company of chasseurs, and that he distinguished himself there, and that if his individual conduct corresponded with his zeal and his intelligence for his profession, much might be expected from him. He is ambitious, and the good-will

${ }^{1}$ Brette, La révolution française, xxix., 26 I. 
that he displayed in the campaign that he has just made in Corsica leads M. de Vioméril to believe that he may turn out well and then he would be a very interesting character. To encourage him, M. de Vioménil thinks that it would be in order to accord him the rank of captain.

"His good conduct," went on the report, "could not yet be sufficiently counted upon to justify his appointment as captain of cavalry or of dragoons; but while waiting for him to attain intellectual maturity, the Marquis de Mirabeau desired that he should be given a commission in the corps of dragoons and that he continue to serve in the Legion of Lorraine." Here he would have the advantage of receiving the counsel of Vioménil. Out of consideration for the ranking lieutenants of the legion, the marquis did not ask that the captain's commission of his son should attach him to that corps. In other words, Mirabeau received a captain's commission, but he would have no company until his father bought one for him. He was "to continue to serve in the Legion of Lorraine as second lieutenant." More than that, "the commission of captain would not be remitted to M. de Mirabeau the younger. It would simply be shown to him, that by means of this rank, that he desires so much, his attention may be turned upon himself and his emulation aroused." 1 In informing the marquis of the favorable action that had been taken upon his request, the minister wrote that "His Majesty has been pleased to listen favourably to the account that I have given him of his zeal, of his bravery, and of his application, and he has accorded to him the commission of captain; he will be attached in this quality to the corps of dragoons." 2

2 Brette, La révolution française, xxix., 263.

2 Montigny, Mémoires de Mirabeau, i., Iзo. 
There was no longer any obstacle in the way of Mirabeau's appearance in Paris. ${ }^{1} \mathrm{H}$ is apparition was, however, unexpected. "Your brother-in-law arrived the day before yesterday," wrote the marquis to Du Saillant, the I 4 th of February, "from Limoges in three days in the midst of an icy rain of the worst description, and after many falls and contusions, at a moment when he was the least expected."' Mirabeau's reception pleased him much. "I have been overwhelmed with kindness and I see that this time his heart has been entirely won," ${ }^{3}$ he wrote to his sister. The attitude of the marquis toward his son was, in truth, irreproachable. In a letter in which he informed the bailli of Mirabeau's arrival in Paris, "after having done his work well down there," he showed a genuine pleasure in describing the occupations of the young man during his first week in the city, his journeys to Montargis and Bignon, and in planning for his future.

We thought him rough [he remarked], and he was. . . . To-day I fear that he is too ready to take the colour of the people with whom he associates and that is why I shall keep

1 The marquis had written to his son, then en route, the following letter: "Mon enfant, je vous écris ce même courrier au Saillant et en détail; mais, comme je crains que ma lettre ne vous manque, comme ont fait plusieurs autres, je vous adresse ce billet poste restante à Limoges, pour vous rappeller deux points: I. Que vous voyiez M. l'évêque en passant, preniez ses commissions et lui fassiez de ma part toute sorte d'hommages. 2. Que vous ne m'ameniez votre nègre. Je viens de vous en dire les raisons dans ma précédente, adressée au Saillant; je ne vous le repéterai pas ici. Adieu, ne vous cassez ni bras ni jambes. Je vous embrasse."-Published by M. Charles de Ribbe in the Mémoires d'Académie d'Aix, viii., 39 I.

2 Montigny, Mémoires de Mirabeau, i., 368. The marquis to the Comte du Saillant, February I6, I 77 I.

${ }^{3}$ Ibid., Mirabeau to the Comtesse du Saillant, February I6, I 77 I. 


\section{In the Confidence of his Father}

him much with you or with me; fortunately his commission does not call for any service. My way of treating him is far from pedantic. He is as free here as you could ever be, but I know of excellent young men with whom he is already on good terms. I have already presented him to Maréchal de Broglie, in accordance with his desire. On his return from Montargis, he will be introduced to everybody at Versailles. The excellent Laqueville assured him that he ought to be presented to Prince de Conde, as all the young officers of the nobility assemble there. Bene sit, but that being so, he will meet everybody. [The marquis was determined to place no obstacle in the way of his son's advancement in society.] It will relieve me of the suspicion of wishing to make a philosopher of him [he explained]. $\mathrm{He}$ is as engaging as I was unsociable and he seems to know everybody that was in Corsica. . . . I have the welfare of my children very much at heart [he wrote, in closing this letter]. I have only these two to place [to marry] and the eldest will give me occupation enough. ${ }^{1}$

Two weeks later, the marquis informed his brother that his nephew had passed favourably through all his presentations at Versailles. ${ }^{2}$

$\mathrm{He}$ is going to-day [he continued] to call upon Duc

1 Correspondance générale, vi., 464 . The marquis to the bailli, Paris, February 18, I77I.

2 It was necessary to prove his nobility as far back as I400. "Comme, en outre, on ne reçoit que piéces originales, les preuves de la court sont excessivement fortes." It sometimes happened that people of most distinguished birth were kept waiting for years. "Cela me serait arrivé, à moi, si le maréchal de Noailles d'aujourd'hui, ennuye des longueurs de Baujon, n'eat fait écrire une lettre de commandement à Chérin d'en finir; mais il est vrai que mon père n'avait point daigné faire un pas."-Lettres originales de Mirabeau, iv., 282. Mirabeau complains elsewhere in the same correspondence (iv., 269): "J'eus toutes les peines du monde à obtenir communication [from his father] de nos papiers et permission d'y travailler, lorsqu'il me fallut monter dans les carosses." It was on this occasion that he had his rencontre with Madame Elizabeth, who asked him if he had been inoculated.

vor. 1-t9 
d'Orleans, Prince de Condé. After that, their dinners, their suppers, the other princes, etc. Society has changed much since our day. There are hunting parties and social gatherings. $\mathrm{He}$ is very well suited to that sort of thing. His manner is respectful and not base, easy and not familiar. He has been invited to hunting parties, drives, suppers, etc. I shall let him follow up this sort of thing, expensive as it is, but one of the indispensable things to-day and that helps bright people in getting what they are after. The rascal will carry things with a rush. Fortunately, the Marquis de la Queville, one of the best behaved and most reputable young men of his day, the eldest of a numerous family of which he is the father, and one of my most zealous followers, has taken charge of him, and you cannot imagine what a help Providence has been to me on this occasion. ${ }^{1}$

Such a Mirabeau had never been seen before at Versailles. The marquis followed with evident satisfaction the social successes of his son.

Your nephew passes three days in the week at Versailles [he wrote to his brother]. He usurps nothing and gets everything, finds all doors open to him. Everybody is a relative of his, the Guemenee through the Carignans. The Noailles take him about. They find him as wild as a young brach-hound. Madame de Darfort asserts that he would upset the dignity of all courts already born or to be born. But they find that he has more wit than all of them, a thing that is not very shrewd. When I am asked why I let him go to Versailles when he is so young, I reply:

1 Correspondance générale, vi., 475. The marquis to the bailli, Paris, March 5, 1771. Either at this time, or during his life at the Choquard pension, Mirabeau saw much of the shady side of the great city. See his statements to Sophie de Monnier, Lettres originales de Mirabeau (iv., I44, 145), where he describes "des orgies de jeunes gens." Such affairs were en règle in the life of a young nobleman in the eighteenth century and caused no scandal. The marquis does not complain of his son's shortcomings in this respect. 
There he will act extravagantly only in good company, socalled; as long as I saw that he was gauche, I kept him hidden; as soon as. I see that he is adroit, he has his rights. After all, for the past five hundred years, the world has tolerated Mirabeaus who have never been made like other men, and it can still tolerate this one. I promise you, furthermore [he exclaimed, in a tone that is seldom encountered in his letters when writing of his eldest son], I promise you that that one will not disgrace the name. ${ }^{1}$

Never before had such kindly relations existed between Mirabeau and his father. So great was the confidence of the bailli in his nephew at this time that he suggested that Boniface could be placed in the same regiment with his brother, the legion of Lorraine, even if he had to enroll as a soldier. The elder brother was to act as a semi-mentor of the younger and would be rendered wise himself by his task. "I am very much pleased," 2 he wrote to the marquis, "with what you say about your eldest son."

Mirabeau had reached Paris the I4th of February; the I2th of April, a change was already apparent in his father's attitude toward him. "At the rate at which his brother, the whirlwind, is going-who will soon, I believe, have blown up the court and the city-when the head is fully developed the body will still need supports, and Boniface, upon whom I have always had designs, needs to be taken care of." 3 Before the arrival of Mirabeau in Paris his father had planned

1 Correspondance générale, vi., 480. The marquis to the bailli, Paris, March 20, I77 I. The marquis referred to his son, at a later day, as "this young man who took Maurepas by the button-hole." -Ibid., ix., 348. The marquis to the bailli, Bignon, September I, I780.

2 Ibid., vi., 489. The bailli to the marquis, Aix, April I, I77x.

3 Ibid., vi., 49r. The marquis to the bailli, Paris, April r2, r 77 r. 
to take him with him on a visit to the family estate in Provence. ${ }^{1}$ This plan was now abandoned. ${ }^{2} \mathrm{He}$ had confidence in the good influence of the Du Saillant family, but distrusted Madame de Cabris and would keep his son away from "those of Provence. I have seen enough of them." The nervous strain, resulting from constant intercourse with his "whirlwind" of a son, began to grow burdensome. "Furthermore," he explained to the bailli, "the continual contention of spirit in which he keeps me, so much the more severe as it is more concealed, does not fail to become oppressive at last." His son's "impetuosity," his "chopping up of ideas, a mind that sees everything by lightning flashes, but follows up nothing," all this irritated the marquis. Moreover, all Paris was agitated over the coup d'état of Maupeou against the parliaments. "If you could see what is passing here," wrote the marquis to his brother, "the universal fermentation, and the material necessarily and for a long time prepared to push all parties to extremities, you would judge that it is sufficient for a thinker to be his own compass and that the rôle of moderator is a bit too much." 3

This last remark referred, I assume, to the difficulty that the marquis experienced in preventing his son from taking the side of the parliaments against the ministry. It was at this time that Mirabeau began to play his part as an opponent of absolutism, a rôle that he never abandoned until his death. In a letter written in 1776 to the Gazette litteraire of Holland,

1 Correspondance générale, vi., 440. The marquis to the bailli, Paris, January II, 177I; vi., 453. The bailli to the marquis, Manosque, January 22, 1771 ; vi., 454 . The marquis to the bailli, Paris, February 4, 1771 .

2 Ibid., vi., 491. The marquis to the bailli, Paris, April 12, 1771. s Ibid. 


\section{In the Confidence of his Father}

Mirabeau gave an account of his attitude at Paris in the spring of $\mathrm{r} 77 \mathrm{I}$. After describing the acts of the ministry, he went on:

It is by such means that the reign of Louis XV. became, in the hands of the Terrays and the Maupeuos, the most disastrous epoch of the monarchy. Despair was at its height. Suicide made its appearance in the country of gaiety, of pleasures. Some individuals raised their feeble voices and pleaded the cause of the nation with more intelligence than force; the public chaffed and joked and France was within a hair's-breadth of ruin.

What a spectacle for a man who, in the first enthusiasm of youth, believes that it is impossible to be the accomplice of evil-doers, when they stand exposed! Who hopes that reason will be stronger than brute force! A strange mistake, without doubt, and one that he soon perceived.

However, he put forth boldly the most dignified principles, displayed the most zealous patriotism. His courage would have been the most dangerous temerity had he not been safe-guarded by his youth. He feared nothing; he was indignant at seeing all the orders tremble; the magistracy show its weakness; the military force vaunt itself the mercenary, the blind satellite of the despot; the princes of the blood lose time in vain words, while the social structure was crumbling on all sides; in such circumstances, pusillanimity seemed to him the vilest of weaknesses, perhaps even a treasonable crime. In vain the Marquis de Mirabeau cried to him, Your ancestors were always royalists; the young patriot felt that an honest man could not be a royalist when all the nation was in the party of opposition. ${ }^{1}$

After due allowance has been made for the influence of time and the circumstances under which this letter was written, the substance of the account is probably

${ }_{1}^{1}$ Essai sur le despotisme, p. xx. 
true. It harmonises with the character of Mirabeau and with his attitude toward the new parliaments. Moreover, it is highly probable that he began at this time the studies that supplied him with material for his Essai sur le despotisme. There can be little doubt of the fact that this work was a political pamphlet and the product of the struggle between the monarchy and the parliaments. In the middle of May, the marquis wrote that he had withdrawn his son from Versailles and "cast him into the libraries, where he passes entire days with Gébelin and then M. de Pompignan in relays; and he works and pores over old books like the madman that he is, as he does everything." 1 What was he doing in the libraries, if he was not gathering the material that later went into his book? The evidence does not justify the assertion that the idea of the book was already conceived; Mirabeau was clearly, however, an active partisan of the parliaments and it is highly probable that he was engaged in the libraries in investigating the history of arbitrary power, especially in France.

The efforts of the marquis to occupy his son had not been fruitful and he had evidently "cast him into the libraries" in despair. In April, the Comte du Muy was preparing for a tour of inspection that would take him through Flanders, the Three Bishoprics, and Alsace. Although the marquis had friends no less influential than "Mesdames les filles du roi," he was not very confident that he would be able to induce the count, one of "those cold people. whom nothing moves," although an "honest and estimable man," to take his son with him. On the 23d of April, he informed his brother that

${ }^{1}$ Montigny, Mémoires de Mirabeau, ii., 374. The marquis to the Comtesse de Rochefort, May I I, I 77 I. 
the count would take no one with him and had "refused me honestly and all by whom he was approached in my behalf, including Mesdames." 1 The bailli was much disappointed, but undertook to place his nephew in Corsica, with the Baron de Marboeuf. The project was evidently conceived by Mirabeau. The request was made by the bailli; the reply of the baron "could not be more polished and honest, but negative," commented the bailli. ${ }^{2}$ A last attempt was made to place him with the Baron de Vioménil, who proposed to go to Hungary to enter the service of the emperor. "The expense will be considerable," observed the marquis, " but I have ordinarily spared nothing for form's sake. The trouble is that we are in such high favour that the emperor wants no French about him. I have not as yet given up all hope in this matter and it will be absolutely decided only at the end of the week. If nothing comes of it, I shall send him to his brother-inlaw and to the Laquenilles." He was clearly at his wit's end. "In truth," he exclaimed, "one does not know what to do with a young man of genius, for the very reason that he must do good or do harm, and in general, the situation is similar to that after a battle has been lost; one sees resources nowhere. As for myself, who concern myself only with my own affairs, this young man is not the least of my casse-têtes, and, in truth, I have many of them." 3 A week later he wrote that "the active Vioménil has gotten no further on his journey to Hungary than to $I$ will speak of it to the

1 Correspondance générale, vi., 49 I, 494, 495. The marquis to the bailli, Paris, April I2, I77 r; the bailli to the marquis, Aix, April I4, $177 \mathrm{I}$; the marquis to the bailli, Paris, April 23, I $77 \mathrm{I}$.

2 Ibid., vi., 499, 504. The marquis to the bailli, Paris, May 7, I 77 I t the bailli to the marquis, Mirabeau, May II, I 77 I.

3 Ibid., vi., 509. The marquis to the bailli, Paris, May 3 I, I 77 I. 
king. My young man has, with reason, this journey very much at heart. I cannot leave him here and I have promised to be patient until then. If that is not decided, I shall send him to Limousin, where I have some matters to be looked after." The I 4 th of June he wrote to his brother, "My son has set out for Limousin." Vioménil, like Du Muy and Marboeuf, had failed him. ${ }^{1}$

The marquis had sent his son to Limousin as much for the purpose of getting rid of him as for the ostensible reason of caring for his affairs. I have already noted that his letters showed a growing irritation, an evident return to a state of mind similar to that which had preceded the reconciliation. What was the cause of it? The bailli himself did not understand it, although he had marked the change. "With your permission," he wrote, "you tell me too much or too little about your eldest. If his faults are due to verdure, although they may be grave, my heart would not permit me to give him up. If they come from the heart"- that would be another matter. If the marquis really had reason to complain of his son, the uncle would be more implacable than the father. "But I should like to be better informed upon this subject," 2 he concluded. "Little-by-little," replied his brother, "I shall accustom myself to the uneasiness that your nephew caused me. He would make one afraid of everything, I believe, but at bottom it is only that. He sticks to nothing and concerns himself with everything. It is necessary to caution him constantly, but he has no desire to do any

1 Correspondance generrale, vi., $5 \mathrm{Ir}, 5 \mathrm{r2}$. The marquis to the bailli, Paris, June 7 and 14,177 .

2Ibid., vi., 50r. The bailli to the marquis, Mirabeau, May 4, I 771 . 
harm." 1 In a letter written three weeks later, he is not so considerate in his estimate of his son:

The society of this young man is rude and fatiguing. A stubborness, a cocksureness, a chaos in his head that will never assume form for the reason that he has only aperşus of memory like everything else. He has no doubts about anything and yet does not know his own name with any certainty; and as it is forever denied him to have any clear notions, he will always be insupportable and [whatever he says] indubitable; it is I who tell you this. In addition to that, much perspicacity and I believe a rare talent for his profession, superannuated and as much out of style as tournaments. . . . But, at bottom, I believe that to calm him and to extinguish him are pretty nearly the same thing. God is over all. ${ }^{2}$

The situation is not unintelligible. The fundamental cause of the changing attitude of the marquis toward his son is clearly to be found in the lack of sympathy between the two men due to two very unlike characters and temperaments. In reading the characterisation of the younger man by the elder, the mind naturally reverts to the remark of Gilbert Elliot to his brother Hugh: "I loved him, then, however, and so did you, though, as he confesses, you sometimes quarrelled with him, being always somewhat less patient in admitting extreme pretensions than I." The extreme pretensions of Mirabeau amused and interested his uncle; they evidently irritated his father. In later years, Mirabeau attributed this attitude of his father toward him to the jealousy of the marquis. He declared that, "oppressed by the truth," he said to his father, "But, my father, if you only had enough amour-

1 Correspondance générale, vi., 503. The marquis to the bailli, Paris, May, I 77 I.

2 Ibid., vi., 5II. The marquis to the bailli, Paris, June 7 , I 77 I. 
propre, you would look upon my successes as yours." 1 It is hardly necessary to resort to such explanations. It would be difficult for two such natures to live together in harmony were there no other causes for disagreement than those found in their incompatible temperaments. Mirabeau claimed in later years that there were such causes. "I will not speak," he wrote to his father from Vincennes, "of the vexations caused me by the misrepresentations of those about you, the winter that I passed at Paris, and with which I became acquainted only in roundabout ways, for, although your face betrayed your uneasiness, you remained silent." 2 The person referred to in this passage is evidently Madame de Pailly. To what extent, if any, she used her influence with the marquis to injure Mirabeau, we have no means of knowing.

When Mirabeau left Paris for Limousin in June, I 77I, the relations between father and son were still outwardly harmonious. Mirabeau looked upon the fact that he was sent to Limousin to take charge of the estates as evidence that his father was not discontented with him. ${ }^{3}$ "Here he was absolutely abandoned to himself, in the pursuit of his rural occupations ... but our documents show," comments M. de Montigny, "that this isolation was a snare skilfully laid by the ingenious hate of Madame de Pailly." 4 What these documents are, he does not state; this writer, so scrupulous in citing evidence for every statement, contents himself at this point with bare assertion. I know of nothing that could be cited but the words of Mirabeau given above. In the same Mémoire of

1 Essai sur le despotisme, p. xxii.

2 Lettres originales de Mirabeau, i., 297, 298.

3 Ibid.

4 Montigny, Mémoires de Mirabeau, i., 375. 
Vincennes, Mirabeau, writing to his father, says: "This year, as the preceding, you deigned to shower encomiums upon my administration, doubtless to encourage me to merit them. You approved of all that I did. I had the good fortune to render you some services that you called important, and I recovered my feeling of security. . . ." 1 He even proposed to rent from his father the lands in Limousin and to undertake to bring large areas under cultivation. ${ }^{2}$ The marquis seemed inclined to accept the proposition and advised his son to consider the plan seriously, but when Mirabeau returned to Bignon in November, $177 \mathrm{x}$, and "entered into the details of the proposition," his father, he claimed, "would say neither yes nor no. I pressed you; you refused me dryly. I saw clearly that someone had prejudiced you and had induced you to change your own opinions; for nothing was more in accord with your principles and your interests than that which I asked of you." 3 A letter, written by Mirabeau to his father from Aigueperse, in September, I77I, bears witness to the businesslike manner in which he administered the affairs intrusted to him and to the perfect confidence that apparently still existed between father and son. ${ }^{4}$

A week after his arrival at Bignon, Mirabeau was despatched by his father to Provence to look into the trouble with his vassals at Mirabeau and Beaumont and if possible to put an end to it. He was dismissed "with fresh marks of confidence, but already," observed Mirabeau, "you had begun to distrust me. I

1 Lettres originales de Mirabeau, i., 297, 298.

2 Montigny, Mémoires de Mirabeau, I, 375.

3 Lettres originales de Mirabeau, i., 298.

4 Collection of M. Mouttet. Copy. 
saw it; I was profoundly afflicted by it. I left you at a very critical time. I confided my anguish to my uncle." (The bailli was then at Bignon.) " $\mathrm{He}$ endeavoured to reassure me; he promised me his aid, his vigilance. He urged me to get married, and to get married in Provence. He stated his views in detail. I asked you if they agreed with yours; you answered in ambiguous terms. I departed without any definite plan other than that of fulfilling my mission with all possible zeal and with all the intelligence there was in me." 1

The journey was not without accident. "I am exhausted with fatigue," he wrote to his uncle on his arrival, "not having slept more during the past eight days than a soldier on guard, and having taken the precaution to sound with the wheels of my carriage all the mudholes between Paris and Marseilles." 2 The carriage broke down near Beaune, leaving him alonehis lackey having ridden on in advance-in the late afternoon of a December day, on the highway in the midst of falling snow. He described the incident in a delightfully humorous vein to his uncle. ${ }^{3}$ At Lyons, he was guilty of some excesses. " One of my relatives," he later affirmed, "exposed me to seducing temptations. I did not resist. This foolishness was not very dear; but it was a piece of foolishness. . . . Hardly had I arrived at Mirabeau, when I learned that I had been watched and followed to Lyons by your [the marquis's] orders. This severe inquisition proved to me that you had conceived suspicions that I did not merit. It

1 Lettres originales de Mirabeau, i., 298, 299.

2 Montigny, Mémoires de Mirabeau, i., 378 380. Mirabeau to the bailli, December I 2, I 77 I.

IIbid. 
wounded me deeply. I followed a straightforward and honest course; I told my uncle everything. I was scolded; I expected it; I hoped to be pardoned; I was not." 1 Not all these reflections of a later date should be treated as so much matter of fact, but there seems no reason to assume that Mirabeau's escapade, measured by the standard of the day, was a very serious affair nor to deny that his father employed a spy to follow him on his journey. The simple assertions of Mirabeau prove nothing, but for the most part they are as worthy of consideration as the assertions of his father. He has not always been given a fair hearing. ${ }^{2}$

The task that his father had set him in Provence was far more difficult than anything that had yet engaged his attention. In Limousin, he had laboured in the interest of his father's vassals; in Provence, he was to defend the interests of his father against his vassals. He was to undertake to do this among a people insistent upon their rights and among whom the revolutionary spirit was already fermenting. The spirit of this province was wholly unlike that of the more northern provinces. Perhaps it could not be better described than in the words of the bailli to the marquis in speaking of the shortcomings of the land to which he was

1 Lettres originales de Mirabeau, i., 299.

2 In the past there has been a marked tendency among the biographers of Mirabeau to follow almost exclusively the testimony of either the father or of the son, the testimony of the one being uniformly accepted and that of the other rejected. Neither the marquis nor his son was a dispassionate purveyor of truth. What witness is at all times? I have not treated the testimony of either en bloc, clearly an unscientific method, but have endeavoured to determine what the testimony of each was worth in each particular case. I can hardly flatter myself that I have always been successful, but I am conscious of endeavouring to examine carefully and fairly all the evidence. 
warmly attached: "All the inhabitants, after having made many reverences and said flattering things to their young seigneur, will watch for an opportunity to vex him." 1 He referred to Provence as "completely conquered by the inkstand." 2 The marquis once said that "Provence alone supplied more libels and mémoires than all the rest of the kingdom together" 3 and Mirabeau declared that he had heard his father say "a hundred times that calumnies and defamatory writings were the favorite sins of this region." 4

The chief object of Mirabeau's visit to Provence was to punish the inhabitants of the estates of Mirabeau and Beaumont who insisted on cutting wood and pasturing cattle upon land that they asserted belonged to the communities while the marquis claimed that it was not public property. To simply assert his rights was not sufficient with a people that did not hesitate to defend themselves in the courts against what they considered the encroachments of the seigneur. The marquis appears to have been constantly engaged in lawsuits with the communities of Beaumont and Mirabeau. "Certain citizens, proprietors of certain more or less important farms, directed the deliberations of the councils of the communities, regularly elected and assembled, and exercised in turn the functions of consul in a spirit hostile to the seigneur. It was above all a

1 Correspondance générale, vi., 436. The bailli to the marquis, Manosque, December 29, I770.

2 Ibid.

3 Lettres originales de Mirabeau, i., 309. The bailli once used the same language: "Cette province-ci renferme plus d'animaux armés d'écriture que 22 royaumes bien policés n'en devraient renfermer. Or cette espèce est la plus venimeuse et la plus polémique pour la bonne foi et les bonnes moeurs."-Correspondance générale, vi., 406. The bailli to the marquis, Mirabeau, October 23, 1771 .

4 Lettres originales de Mirabeau, i., 3 ro. 


\section{In the Confidence of his Father}

procureur of Aix, a M. Mottet, who was the bete noir of the marquis and the chief of the opposition against him."1

The marquis had attempted to settle the question of the rights of the community to wood and pasturage by having his judge render an ordinance assimilating the woods to the state forests and applying to them the regulations of the royal ordinance of 1669 . The communities resisted; Mirabeau was sent to restore order and to enforce the ordinance. "Apropos of fools," wrote the marquis in December, I77I, "I have sent the elixir of my race in this sort to Mirabeau to deal with some popular foolishness that my police regulations on the forests caused as soon as I had turned my back." 2

On his arrival at Mirabeau, the count sent to the consuls of the village, as proof of his authority, the letter of credit that he had received from his father. He endeavoured to appeal to the people and to adjust the affair in an amicable manner, but he met with opposition on the part of the officials of the town and even of the men who held office at the hands of his father. They took sides with the community and resigned their offices without hesitation. Finding that nothing could be obtained by fair means, Mirabeau resorted to vigorous measures. He took legal action against persons found carrying away wood from the forest; mules loaded

1 Loménie, iii., 70-80. M. de Loménie publishes a number of letters of Gastaud, a notary of the village of Mirabeau, in which the action of the count is presented in a very unfavourable light. Montigny, Mémoires de Mirabeau (i.,380-382), contains extracts from the letters of the Abbe Castagny to the marquis, in which Mirabeau appears in a more favourable light. Mirabeau himself refers to the subject in Lettres originales de Mirabeau, i., 300.

2 Loménie, iii., 75. 
with wood were seized by the guards. But all his efforts were in vain. The communities resisted, appealed to the parliament of Provence, and the ordinance of the judge against which protest had been raised was annulled. ${ }^{1}$

The rôle played by Mirabeau in this affair is curiously in contrast with his acts in Limousin and even in Provence in later years. Here was the young son, defending the rights of his father "whose goodness had been abused," and threatening to lay a heavy hand upon the communities if they did not submit. His action seemingly produced "more discontent than fear" among the vassals of his father. As long as the count remained in Provence and administered the estate the strained relations continued and no satisfactory modus vivendi was found.

The marquis was naturally dissatisfied with the failure of his son to find a solution for a very complex problem and doubtless censured him more severely than was justifiable. ${ }^{2}$ The relations between the two were not improved by the letters of the father. In truth, the short period during which Mirabeau had enjoyed the confidence of his father was drawing to a close. The explanation of the change in the attitude of the Marquis de Mirabeau toward his son cannot be found in any specific act on the part of the son that had turned his father against him. During these two years the only irregularity in Mirabeau's conduct of which any record exists is the affair of Lyons. In the face of all the evidence, one is inclined to give more than a passing consideration to the explanation offered by Mirabeau himself: "I saw that I would always be in

1 Loménie, iii., 70-80.

2 Lettres originales de Mirabeau, i., $30 \mathrm{r}$. 


\section{In the Confidence of his Father $\quad 305$}

the wrong, because I was not loved." 1 Possibly, in the last analysis, when due allowance has been made for Mirabeau's shortcomings, the true explanation of their differences will be found in the fact that the marquis did not love his son. Under the circumstances, it was quite natural that Mirabeau should think seriously of obtaining his independence by contracting a brilliant marriage. Such had been the advice of his uncle and we know that the bailli had been very desirous of seeing his nephew settled in Provence. The marquis did not favour the idea, but he had replied ambiguously when questioned upon the subject. When, therefore, Mirabeau learned from his cousin, Madame de Limaye, that "the public was marrying off Mlle. de Marignane, and counted me among the number of the pretendants," 2 it was quite natural that he should yield to the solicitations of his cousin to go to Aix and enter the ranks of the suitors, although he asserts, "I went there rather from curiosity than with any fixed purpose." 3 It was one of the most momentous acts of his life.

${ }_{1}^{1}$ Lettres originales de Mirabeau, i., 301 .

2 Ibid., i., 302.

3 Ibid.

VOL. $I-20$ 


\section{CHAPTER XII}

\section{THE MARRIAGE OF MIRABEAU}

I $N$ the last quarter of the eighteenth century, Aix en Provence, the theatre of Mirabeau's courtship and marriage, was a city of thirty thousand souls. ${ }^{1}$ It was called by President de Brosses, a contemporary of Mirabeau and a competent critic, "the prettiest city in France after Paris." As the capital of the province, it was the residence of the governor, the lieutenant-general, and the intendant; it was also the seat of a parliament and a court of accounts and the possessor of one of the most valuable libraries in France. "Strangers of distinction came to Aix to consult its libraries, its cabinets of curiosities and antiquities, and to admire its collections of pictures and prints." The society of the place received its tone from a rich and numerous aristocracy and from the presence of royal officials and members of the courts. On the threshold of Italy, Aix was visited by most of the young magistrates who went there to finish their education; it was,

- De Ribbe, Charles, Un journal et un journaliste d $A$ ix avant la révolution (Mémoires de l'académie d'Aix, viii., I68-249). M. de Ribbe draws a picture of the society of Aix from I 770 to 1777 , taking his material from two contemporary newspapers published at Aix, the Affiches d'Aix and the Affiches de Provence. The population of Aix at this time he treats in an appendix. According to the census of 1770 , the population of the city was 28,448 . It is probable that it was not less in 1772 . 


\section{The Marriage of Mirabeau}

also, a favourite residence for Englishmen, who spent their money freely within its walls.

The best society of Aix yielded nothing to Paris in the matter of luxury. The "young seigneurs wore belaced and embroidered habits, shirts of Dutch linen with beautiful gold-embroidered cuffs, laces, and handkerchiefs from India. But nothing equalled the magnificence of the toilettes of the ladies, above all of their coiffure." These fair dames rode in carriages "resplendent with Bohemian glass, cameo paintings, and gilded ornaments," or were carried in sedan chairs, "gilded, lined with velvet, and displaying their coats of arms." Balls, concerts, theatres, and fêtes formed their amusements, and a "Cour d'Amour," the constant occupation of a select coterie, assembled at the chateau de Tourvès, the residence of the Comte de Valbelle. ${ }^{1}$ The queen of the court was Madame des Rollands, and one of the most devoted courtiers the Marquis de Marignane.

"In the spring of 1772 , in the aristocratic salons of Aix, gossip was busy with the problem of who should marry Mlle. Emilie de Covet, the unique heiress of the Marignanes, the richest catch of the province." The only daughter of the Marquis de Marignane, Mlle. Marie-Marguerite-Emilie de Covet de Marignane was born at Aix, September 3, I 752, and was, at this time, not quite twenty years of age. Her childhood had not been a happy one. "Neglected by her father, ill treated by her mother, who lived apart from her husband, the poor child grew up únder the rod of her paternal grandmother, dubbed La Renarelle on account of her ill humour and shrewish temper." 2 In I 763 , immediately

2 Mouttet, Mirabeau en Provence, 2.

2 Ibid., Iоr: "Du verbe provençal renar, qui signifie, grogner, gronder." The source from which M. Moutett drew his information 
after the death of a younger sister, Emilie was taken from her mother by her father and placed in a convent. A friend of the family wrote at the time "that the cruelties of the mother toward her daughters had led the physician to say that after having caused the death of the younger, she would cause that of the elder, if the child was not taken away from her." 1 The Marquise de Marignane occupied her father's house at Aix, near the residence of her husband; the marquis passed much of his time at the chateau de Tourvès in the company of his friend, Madame de Croze. It was another mariage de convenance. ${ }^{2}$

For some years the daughter had been of a marriageable age. It will be recalled that two years before

concerning the treatment of the child, is partly a letter of the bailli, in which he wrote: "M. de Marignane étant séparé de sa femme, Emilie vivait assez tristement, grondée du matin au soir par son aieule où elle demeurait, et qu'on nommait par excellence La Renarelle, négligée par son père et maltraitée par sa mère" (Quoted by M. de Montigny in Mémoires de Mirabeau, ii., 6). M. Guibal (Mirabeau et La Provence, i., Iox) thinks that the bailli exaggerated. He believes that "les lettres de Mlle. de Marignane [some of which he publishes in an appendix to his first volume] pleines d'enjouement, nous donnent l'idée d'une enfant heureuse, choyée et presque un peu adulee." That certainly is the impression made by the letters, but they were written in 1769 and 1770 and it does not necessarily follow that the real childhood of Mlle. de Marignane was not unhappy. It is, however, a convincing reply to the statement of the bailli that the young lady was so ill-treated that she was glad to get married. See, also, Correspondance générale, viii., 363 . The bailli to the marquis, December 30,1778 : "Elle a été élevée de manière à la rendre mauvaise."

1 The letter was written by M. de Montvallon, the father of Madame des Rollands. It is dated Aix, April 27, 1763. As this letter is unpublished and contains the most of what we know concerning the childhood of Mlle. de Marignane, I have reproduced it in Appendix II.

2 Mouttet, Mirabeau en Provence, 6; Loménie, iii., 84, letter of Mirabeau to Madame du Saillant, October I 5, I 780. 


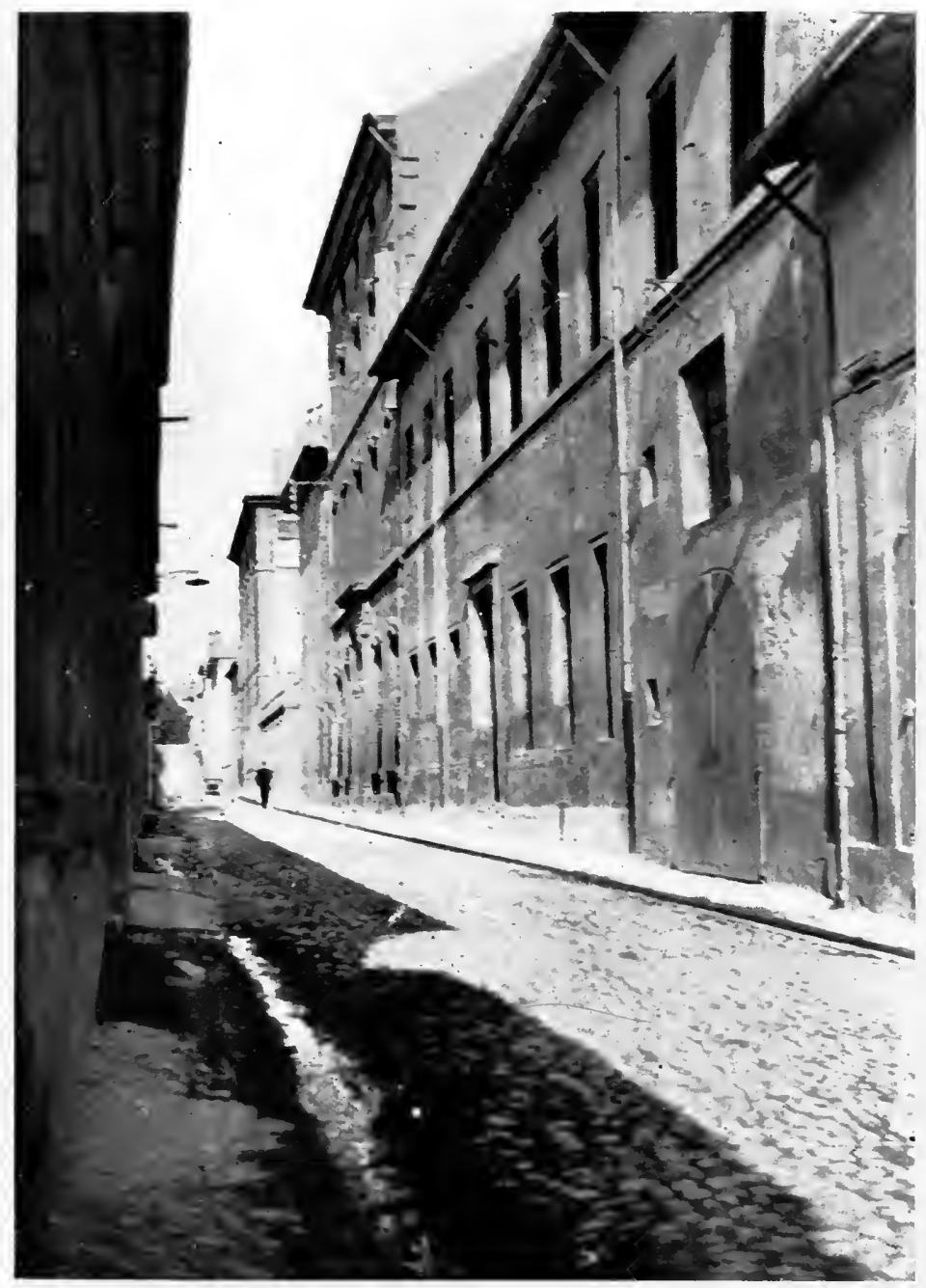

The Residence of Mademoiselle de Marignane at Aix First house on the right

From a photograph by H. D. Fling 

this the bailli had mentioned her to the marquis as a desirable "party" for his nephew. In 1772, the suitors were numerous; rumour mentioned "the Comte de Valbelle, M. de La Valette, the Marquis de Grammont, M. d'Albertas, the Marquis de Caumont, all the fine flower of Provençal nobility, and each had his partisans; but the one who seemed likely to win her from all the others was the magnificent Comte de Valbelle, Marquis de Tourvès, the most intimate friend of the Marquis de Marignane." 1 It is true that the count was forty-three, while Mlle. Emilie was not yet twenty, but such a disparity in age was a common thing under the ancient régime. The Marquise (dowager) de Valbelle, the mother of the count, was enthusiastic over the proposed match and hastened from Paris to Aix expressly to consummate it; when she arrived, it was a matter of history. Madame Polixens des Rollands, called "Queen of the Court of Love," the dear friend of the Comte de Valbelle, "very much alarmed at the proposed marriage, had set herself against it, and because of her tears, her prayers, and even her threats, the Comte de Valbelle, who was in the front rank of the suitors, was obliged to retire." Madame des Rollands had been married very young, in 1757 , to an old chevalier de Malte. Her husband was now an octogenarian and "the marriage of the Comte de Valbelle with Mlle. de Marignane would have wrecked all the hopes of this woman and caused her to lose the 'arrhes' that she had too ostensibly showered upon the Marquis de Tourvès." She was even referred to by the gossips as "the lady of the chateau." 2

1 Mouttet, Mirabean en Provence, i., 2. Loménie, as above.

2 Mouttet and Loménie as above. 
The retreat of the Comte de Valbelle had restored peace and gaiety to the society of Tourvès, troubled for an instant by the untoward project of marriage of the lord of the chateau with Mlle. de Marignane. The pleasures and the fêtes were renewed; all the pretendants had taken heart again and each one was aided by his relatives and his friends.

The Queen of the Court of Love, once more joyous and tranquil, had joined the party of M. de La Valette. Madame de Croze, the friend of the Marquis de Marignane, had added her influence in his favour, and the marquis, without consulting his daughter, came to an understanding with M. de La Valette, whom he loved much.1

The contract was about to be drawn up, the marriage about to be consummated, when a new pretendant, the Comte de Mirabeau, appeared upon the scene.

Hardly had I arrived [wrote Mirabeau to his father] ${ }^{2}$ when M. de Clapiers confirmed the public rumours [that placed him among the suitors] and informed me at the same time that on the following day he would make a proposition to M. de Marignane. Because of the sentiments of my uncle in parting from me I had reasons for believing that his intimate friend had both his instructions and yours. Furthermore, he is one of those born negotiators that cannot be stopped. I allowed, then, M. de Clapiers to do things in his own way. M. de Marignane informed him with proper politeness that he had other engagements. I instructed you of the fact purely and simply. You replied that all of my actions are worthy of each other and that I had lost my fortune by my own fault.

1 Mouttet, Mirabeau en Provence, 13 bis.

2 Lettres originales de Mirabeau, i., 303-3 5 . This account of the negotiations and marriage is contained in a memoir addressed by Mirabeau to his father in ${ }^{2778}$. Mirabeau was at that time a prisoner at Vincennes. It contains much matter not found elsewhere. 


\section{The Marriage of Mirabeau}

Mirabeau felt that the reproach was undeserved. "The marriage of $\mathrm{M}$. de La Valette with Mlle. de Marignane was arranged and the articles drawn up before I reached Aix. I did not deserve, then, what you wrote to me. Unfortunately, and very unfortunately, I was piqued by it and I undertook to undo a marriage almost made in order to prove to you that I had not failed because of my fault." The undertaking was a serious one; the stakes were large. The father of the young lady was a man of importance, if one may infer aught from his titles-" Marquis de Marignane et des Iles d'Or, Seigneur de Vitroles, Gignac, SaintVictoret et autres places, ancien cornette des chevauxlégers de la garde du Roi, gouverneur pour Sa Majesté des Iles d'Or et forteresses de Port-Cros et du Levant, Chevalier de l'Ordre royal et militaire de Saint-Louis." Mlle. de Marignane, in the words of the Marquis de Mirabeau, was "the greatest heiress of our province." The other suitors, Mirabeau asserted, "possessed much more than he was able to offer," although he did not look upon M. La Valette as a dangerous rival.

M. d'Albertas made the most seducing propositions; ... M. de Grammont gave his son twenty-five thousand livres of income and promised him one hundred thousand. Diamonds to the value of one hundred and twenty thousand francs were destined for his daughter-in-law and he made no secret of it. The young man was beautiful as love itself. ... M. de Chabrillant enjoyed thirty thousand livres of income and had a regiment. M. de Caumont is rich and made offers so much the more attractive as many of the estates to which he had pretensions touched those of M. de Marignane. . . All these gentlemen, except the Vicomte de Chabrillant, were near relatives of the Marignanes, and consequently their negotiations became more agreeable and more easy. 
I did not doubt [wrote Mirabeau to his father] that you would be pleased to see me victorious over my rivals, as you had shown humour at seeing me excluded from the list. I deceived myself much. I dare to assert to you, my father, that all the difficulties came from you, and there was need of unbelievable efforts, or rather of unique means of action, in order to overcome them. I overcame them. You went so far as to order me to leave Aix on the eve of my success, in default of which, you said, I ought to be publicly conducted by the police to the Isles SainteMarguerite.

It is highly probable that Mirabeau has correctly described his father's attitude. The first of June, r 772, three weeks before the marriage contract was signed, the marquis wrote to $M$. Bertin, minister of state, that his son had found the means to "conciliate the family of the greatest heiress of our province. They have, so to speak, asked me for him. . . . I replied that they did not know him and we were very far from proposing him for the father of a family, but that I would leave him at Aix, a city very narrow for his hereditary impetuosity, in order that they might know him, and if they persist, I count that he will espouse shortly the heiress of the house of Marignane." 1 If he did not actually throw obstacles in his son's way, the marquis did nothing to help him. ${ }^{2}$

It was in the month of March, I772,3 that Mirabeau, accompanied by his cousin, Madame de Limaye, had arrived in Aix; in April, he was master of the situa-

'Archives nationales, $\mathrm{K}, \mathrm{I6}$, No. 2, I: "Lettre de M. de Mirabeau à M. Bertin, ministre et secrétaire d'état," Paris, June I, I77I.

2 On the 27 th of April, 1772 , the marquis wrote to his intendant at Brie, "Qu'il ne se fait point de délicatesse de dédire son fils." -Archives nationales, $M, 783$, No. I7. Manuscripts of the Marquis de Mirabeau.

3 Montigny, Mémoires de Mirabeau, ii., 9. 


\section{The Marriage of Mirabeau}

tion. He had succeeded by making love to Mlle. de Marignane.

The day was set for signing the articles. All at once, they were astonished to see Mlle. de Marignane undecided ${ }^{1}$; the Court of Love knew very well where the blow came from. It caballed with fury against me. . . . La Vallette gave utterance to remarks about my birth, my person, my fortune; I prove that La Valette has not even the honour of being jaune, as he is not a gentleman; that he will have hardly I 2,000 francs of income. Mlle. de Marignane said to him: "I promised, Monsieur, but it was due to a false exposé." "Who could have had the audacity to say that?" The grandmother, in her falsetto: "It is the Comte de Mirabeau, who requested me to name him"; and La Valette departed the next day. But you may well believe that the Court of Love was a little worse than enraged at it.

"In a week [he wrote elsewhere] M. de La Valette had received his congé; in another week, I was proposed and had a party in the family of the young lady."' In the words of the bailli he had "seduced all the females, ascendantes, déscendantes et de niveau." ${ }_{3}$

Mlle. de Marignane had evidently fallen a victim to Mirabeau's famous power of fascination. ${ }^{4}$ Mirabeau

1 Letter of Mirabeau to his sister, October $\mathrm{I}_{5}$, 1780 , given in Lomenie (iii., 8). It is also printed in part in Montigny, Mémoires de Mirabeau (i., 303) I have followed the text given by M. de Loménie. In Loménie the text reads, "Le jour était pris pour signer les articles," and in Montigny, "Quoique les articles fussent signés avec La Valette." I assume that M. de Loménie is right here on the ground that he reproduces his sources carefully. In the Lettres originales (i., 303), Mirabeau stated that the "mariage . . etait arrangé." His earlier statement is more reliable.

2 Lettres originales, i., $3 \circ 3$.

3 Correspondance générale, vii., 251 . The bailli to the marquis, Marseille, August II, 1776 .

4 She knew what that power was. In a letter written September 29, I 774, she used these words: "Ainsi, mon bon ange, use de cette 
himself claimed, in later years, that it was a love match and there is an abundance of evidence to support his statement. 1 The young lady was not unattractive, although she was not a beauty. We have portraits of her from the pens of both the marquis and the bailli. The latter described her in 1772 , in a letter to his brother, written two months after the marriage: "She had a very ordinary face, even common at first sight; brown, even a little Moorish; beautiful eyes, beautiful hair, teeth not beautiful, but always a charming smile; the figure small, but good, although a little one-sided ${ }^{2}$; showing much wit, ingenuous, fine and sensible, lively, gay, and pleasant, and one of the most essentially pleasing characters." 3 The description written by the marquis, in 1774 , agrees in all important points with that already given. "She has so much sensibility and frankness," he wrote, "that she interests one at once, when her timidity does not stand in her way. She is, furthermore, intelligent, sees everything and judges everything." Roguish, a teller of stories in the Provençal dialect-fort salées, it is true,-the possessor

magie que tu possedes si bien quand tu veux enchanter quelqu'un." This letter is found on page 8 of Observations pour le Comte de Mirabeau ( 1783 ).

1 Ibid., I: "Mlle. de Marignane épousa le 22 de juin, I772, le Cointe de Mirabeau; et tout le monde sait dans cette province si ce époux n' était pas de son choix."

2 Guibal, Mirabeau et La Provence (i., roo, note 3), has the following evidence upon this point: "Devenue Comtesse de Mirabeau, Emilie de Marignane avouait elle-même cette déviation que l'art parvenait à dissimuler. 'Le 5 novembre, 1774 , elle écrivait à son mari: 'Il faut qu'avant l'heure du dîner, j'essaie mon corps, dont je ne puis pas me passer, ayant l'air tout à fait bossue avec l'autre.",

3 Montigny, Mémoires de Mirabeau, ii., 6, quoting a letter of the marquis to the bailli of September I, I772. 


\section{The Marriage of Mirabeau}

of a good voice and no little histrionic ability, ${ }^{1}$ Mlle. de Marignane was certainly not an unattractive person and Mirabeau's interest in her might have been more than mercenary.

To win the favour of the young lady was not sufficient. It was necessary to count with the father, the Marquis de Marignane, who had fixed upon M. de La Valette for a son-in-law. "Piqued by the refusal of his daughter, he said to her: 'You do not want M. de La Valette; very well, you shall not have him; as I do not want M. de Mirabeau, you shall not have him either.' " 2 During the negotiations with Mlle. de Marignane, Mirabeau had informed her that he expected to have r 2,000 livres of income, to be named to the entails of his house, and that he had reason to believe that his uncle would make his home with them. He claimed that he had not stated anything that had not been promised him by his father. When the pecuniary propositions of the marquis arrived they were much below the promises of the son. Mirabeau, so at least he wrote to his father, explained the situation to Mlle. Emilie, pointed out the difficulties of living on the income that they would receive, and offered to release her. Her reply was "all that tenderness could suggest."

1 Quoted by Loménie, iii., 8I, 82. See, also, the remarks of the bailli on the musical and histrionic abilities of his niece in the Correspondance générale, ix., 490. The bailli to the marquis, Aix, March 7, I78r.

2 In 1779 , while at Vincennes, Mirabeau wrote as follows of the Marquis de Marignane: "Il est haut et honnête autant que peut l'être un homme très faible; que si je le voyais une demi-heure, il prêcherait pour moi sa fille; que quand elle eut rompu son mariage avec Lavalette, favori du père, il déclara d'humeur que je ne serais jamais son beau-fils; et ce fut cependant par lui que je gagnai et ramenai toute sa famille."-Lettres originales de Mirabeau, iii., 360. Did Mirabeau fascinate both father and daughter? 
I went to bear to her father [Mirabeau continued] the embarrassing message with which I was charged. $\mathrm{He}$ was revolted by it, but he conducted himself like a gallant gentleman. He withheld his reply to me until he had talked with his daughter; he pressed her to tell him as to a friend what kind of relations existed between us. She talked of inclination; he insisted, she persisted; I received a refusal. I had reason to expect it after the pusillanimity of his daughter. She acknowledged it to me and requested me to repair it. Finally the marriage was consummated contrary to all probability. ${ }^{1}$

To what means did Mirabeau resort to overcome the opposition of the Marquis de Marignane? The tradition, as it existed at Aix some years later, is given by M. Roux-Alphéran in his history of the streets of $\mathrm{Aix}^{2}$ :

Mirabeau bribed a chambermaid, who opened to him stealthily the door of the house at daybreak. He went at once and took his stand in night-robe, with unbuttoned collar, and in underclothes, at one of the windows lighting the stairway on the side of the street, displaying himself thus almost nude to the gaze of the passers-by. The Marquis de Marignane, awakened by the noise purposely made by Mirabeau in addressing some one in the street, hastened to the spot and, believing that he beheld the seducer of his daughter, addressed him in bitter terms, to which Mirabeau replied coldly, Monsieur le Marquis, tomorrow your daughter will be my wife or my mistress. The wedding was in fact celebrated some days afterwards.

The account given by Dumont is somewhat different ${ }^{3}$; about all that it has in common with the other story is that Mirabeau attempted to compromise Mlle. de Marig-

1 Lettres originales de Mirabeau, i., 303, 304, 310-312.

2 Quoted by Mouttet, Mirabeau en Provence, 44. Roux-Alphéran, ii., 403 .

- Dumont, E., Souvenirs sur Mirabeau (Bruxelles, 1832), 206. 


\section{The Marriage of Mirabeau}

nane and thus force herfather to consent to the marriage. In 1776 , in a letter to Malesherbes, Mirabeau wrote: "Mlle. de Marignane was essentially compromised. I loved her, I believed that I was loved, and I resolved to finish the matter." 1 This avowal of Mirabeau would seem to indicate that there was a kernel of truth, at least, in the legend reported so differently by RouxAlpheran and by Dumont. Additional evidence to the same effect is found in the correspondence between the marquis and bailli in 7782 . The marquis advised his son not to appeal to the courts to force his wife to come back to him, but "to resort to a chambermaid who had been bribed, and trusted in that matter to his experience." "A chambermaid that has been bribedwho knows, for it is not for me to teach him these episodes? - would end everything." 2 The bailli did not approve of the method suggested by his brother, remarking that it was "precisely the address with which he had won his wife the first time; that would be sufficient reason for not trying anything of this kind, because they are suspicious." 3 Evidently Mirabeau resorted to a stratagem of some kind to force the hand of his future father-in-law, "counting on success to justify his conduct"; he succeeded.

It is clear from a letter of the Marquis de Mirabeau written the first of May, I772, that an understanding had been reached in April ${ }^{4}$; the wedding did not take

1 Quoted by Loménie, iii., 86.

2 Quoted by Guibal, i., I02; Correspondance générale, x., 405. The marquis to the bailli, Bignon, November 22, 1782 .

3 Ibid.

4 The letter is given in Loménie (iii., 88). After referring to his unwillingness to make a father of a family of his son, the marquis concluded, "Enfin, on s'en charge, on le veut, et moi je le donne." The letter is addressed to the Comtesse de Rochefort. 
place until the $23 \mathrm{~d}$ of June. There was, then, an engagement of two months at least and one portion of the legend is shown to be without foundation. Whatever the stratagem may have been that Mirabeau resorted to, the Marquis de Marignane gave no sign in public that he was not satisfied with his future son-inlaw. ${ }^{1}$ On the $x 7$ th of June, he wrote as follows to the bailli:

It is with the greatest joy, Monsieur, that I received the testimony of approbation that you gave to the conclusion of an affair that I have eagerly desired. Nothing is more pleasing to me than the alliance that incorporates, so to speak, my race with one of those of my province that has so greatly acquired the esteem of the public; I do not doubt that your nephew, having under his eyes the example of his ancestors, guided by a father who has merited the

1 To render complete the account of the methods by which Mirabeau won his wife, it is necessary to add a portion of a letter from the bailli to the marquis, one sentence of which has already been quoted: "Tu juges Marignane fort à la rigueur. Il a donné sa fille à un fol, mais qui avait séduit toutes les femelles ascendantes, déscendantes et de niveau. C'est là le cas du jugement de la femme adultère. Que l'homme qui en sa conscience sentira n'avoir jamais eu de faiblesse de cette espèce, jette la première pierre. Quand les réflexions vinrent, il tait trop tard. Si ce fol avait valu par le caractère La Valette, il lui eut donné un tiers de plus qu' à celui-ci." (Correspondance générale, vii., 25I. The bailli to the marquis, Marseille, August II, I776.) This evidence taken together with the evidence given above seems to make a rather strong case against Mirabeau; it is highly probable, to use his own words, that he employed "des ressorts. uniques" to win his wife. It is well to notice, also, the statement of the bailli that had Mirabeau possessed a character equal to that of La Valette, the Marquis de Marignane would have given him a third more than what had been promised to La Valette. This is, to be sure, only the assertion of the bailli, but it suggests another explanation of the seeming parsimony of the marquis.

See, in Appendix III, an unpublished letter of Madame de Roquessante, Mirabeau's cousin, written probably in June, 1772 . 


\section{The Marriage of Mirabeau}

gratitude of humanity and by the advice of an uncle as respectable as yourself, will labour to conserve all that he has inherited by being born under such happy auspices. ${ }^{1}$

The marriage contract, signed at Aix on the $22 \mathrm{~d}$ of June by M. de Saint-Césaire, as the representative of the marquis, as neither he nor his brother was present during the negotiations nor at the wedding, ${ }^{2}$ is a curious document. ${ }^{3}$ There is an old saying in Provence that "the fathers of Provence give nothing to their children when they marry them"; these fathers of Aix, however, gave something. Judging from the contract, Mirabeau had "great expectations." The Marquis de Marignane gave to his daughter as a dowry 240,000 francs, less 8000 livres that she received in the form of "rings, robes, and trousseau." This dowry, however, was to be received by Mirabeau only on the death of his father-in-law, who was to continue to retain the sum, without interest, until that time. As both Mirabeau and his wife died long years before the Marquis de Marignane, this part of the contract cost the father-in-law little. Moreover, on the decease of the Marquis de Marignane, the

1 Mouttet, Mirabeau en Provence, 49. The copy of the letter, contained in the manuscript work of $M$. Mouttet and as yet unpublished, was made from the original in the collection of M. de Montigny of Aix en Provence.

2 Montigny, Mémoires de Mirabeau (ii., 4, note I), quotes the bailli as writing to the marquis, March 26, I78I: "Je gemirai le reste de ma vie de n'être pas venu en Provence, lors de son mariage."

3 The marriage contract and the "acte de mariage" have been privately printed by M. Mouttet. The original is in the Archives des Bouches-du-Rhone (Aix), Insinuations, reg. I 28 , fo 666 . In an introductory note, M. Mouttet calls attention to the fact that Mirabeau was married on the $23 \mathrm{~d}$ and not on the $22 \mathrm{~d}$ of June. The first date, that of the signing of the contract, is commonly given as the date of the marriage. 
principal did not of necessity go to his son-in-law. It will be remembered that in stating to his brother, the year before, what he would do when he married his son, the Marquis de Mirabeau had assured him that he "would not touch the dowry, although other fathers did so." His mind had changed. The contract provided that the dowry should be paid to him, in case that he had need of it, he to pay five per cent. interest to his son. As a partial equivalent for interest on the unpaid dowry, the Marquis de Marignane agreed to pay 3000 francs a year to his daughter, in semi-annual payments, each payment to be made in advance. In addition to this, the Marquise de Marignane, the paternal grandmother of Mlle. de Marignane, promised her granddaughter the sum of 60,000 livres, "payable at the decease of the said lady, but without interest up to that time."

The Marquis de Mirabeau conferred upon his son the entails of the house - of no value to the son until the death of the father-and 6000 livres annually to be paid from the revenues of "the estates of Mirabeau, Beaumont, Négréaux and their dependances; likewise the said Seigneur Comte de Mirabeau will share with the said Seigneur Marquis de Mirabeau the augmentation of the rent of Mirabeau of I000 livres each year, during the last five years of the lease, which commences in $I 773$, so that the annuity of the said Seigneur Comte de Mirabeau will increase by five hundred livres each year during these five years and at the end of the lease will amount to 8500 annually." Furthermore the marquis gave to his son, as a wedding gift, "all the furniture, linen, furnishings, silver vessels, and generally everything contained in the chateau de Mirabeau, with the reserve to the said Seigneur Marquis de Mirabeau 
of their enjoyment during his life. The italics are my own.

Possibly the Marquis de Marignane was somewhat reconciled to this marriage by the fact that he was to give but 3000 a year while he had promised La Valette 4000.1 The Marquis de Mirabeau made this an excuse for not treating his son more generously. ${ }^{2} \mathrm{He}$ gave, however, the same annuity that he had agreed to give the year before, but at that time he wrote to the bailli that he would "induce his mother to give him as much as possible, but I would promise him 200,000." The evidence shows that he not only made no attempt to induce the Marquise de Mirabeau to give her son anything, but that he did not wish her to give anything. In a letter to M. Bertin of June $\mathrm{I}, \mathrm{I} 77^{2}$, he wrote as follows: "As I name him to the entails in my house, as I have the right to do, and as I have another son, quite differently poised and well born, I do not wish to confide everything to so frail an equipage; it is not my purpose to ask his mother to give him anything for the present." The marquis evidently feared that his wife might take advantage of the marriage to make a settlement in favour of her son that would deprive him of the control of her property. By saying nothing to her about the matter, he avoided this danger and his

1 Montigny, Mémoires de Mirabeau (ii., 10, note 2) quotes from a letter of the marquis to the bailli of May 31,1777 , to the effect that the marriage cost Marignane " 3000 francs au lieu de quatre qu'il donnait à La Valette." The original (Correspondance générale, vii., 366) runs, "Il ne lui en coutait que 3000 francs de rentes au lieu de la qu'il donnait à l'autre." This is a fair illustration of the manner in which $\mathbf{M}$. de Montigny reproduced his texts.

2 "En effet, Marignane diminuant de 1000 ce qu'il donnait pour Lavalette, je n'avais pas besoin de faire le généreux."-Correspondance génerale, $\mathrm{x}$., I4 $\mathrm{I}$. The marquis to the bailli, Bignon, November $3, \mathrm{r} 78 \mathrm{r}$.

voL. I-2I 
son suffered. The marquise did not sign the marriage contract. It was not necessary that she should, as she gave nothing. ${ }^{1}$

The contract also provided that Mirabeau and his wife should live at Aix with the paternal grandmother, the Marquise de Marignane, who would "lodge them and nourish them, their children and domestics, as well in health as in sickness," for a consideration of 2400 francs, paid semi-annually in advance. Mirabeau promised to pay to his wife during their married life the sum of I 500 livres a year, "for her dress and needs."

The contract was signed at Aix, at the Hôtel de Marignane, on the $22 \mathrm{~d}$ of June, 1772 . It is interesting to note among the signatures the name of the Comte de Valbelle, M. d'Albertas, M. de Grammont, and the Marquis de Caumont, all former rivals of Mirabeau. Of further interest is the note following the signatures stating that the expenses of the controle, or government tax, were $95^{\circ}$ livres, 16 sous, and of the registration 2 Io livres, and that these sums had been duly paid. They were, however, paid by Mirabeau and not by his father. ${ }^{2}$

The wedding took place on the following day, June 23, 1772 , in the church of Saint-Esprit. ${ }^{3}$

I urged M. de Marignane [wrote Mirabeau, in giving an account of this event to his father] to allow the wedding to take place at Marignane, where it would have cost us almost nothing. He did not wish it. You know, my

1 Archives nationales, $\mathrm{K}, \mathrm{I} 64, \mathrm{No} .2, \mathrm{x}$.

2 “M. Raspaud m'a demandé une grosse somme pour frais de contrôle, et j'avais espéré que vous me la passeriez en compte, et feriez ce cadeau à M. votre fils."-Montigny, Mémoires de Mirabeau, ii., 14. M. Clapiers to the Marquis de Mirabeau June 24, 1772.

${ }^{3}$ Mouttet, Documents inédits sur Mirabeau (12), extract from the register of the parish. 


\section{The Marriage of Mirabeau}

father, but, unfortunately for me, you wished to ignore it at the time, that it is the custom in Provence to give presents to all that come to the wedding. It was sumptuous; the house was crowded for a week. Madame de Mirabeau had numberless friends who at the time of their marriage had given her very beautiful presents. It was not fitting for her to give them anything less beautiful. Madame de Mirabeau was married with a single robe, and this robe was of taffeta; it seemed to me that she had need of others. These facts are incontestable. M. de Suzaire insinuated all that to you. You replied by a refusal to give me any ready money. ${ }^{1}$

The marquis "sent his future daughter-in-law diamonds and other presents to the value of $\mathrm{x} 2,000$ livres, and the bailli provided the corbeille" or wedding presents from the groom to the bride. ${ }^{2}$

The honeymoon was passed at Marignane, at Tourvès, and at Hyères. While at Marignane, a scene occurred that later was to become notorious in the divorce case between Mirabeau and his wife. "Some days after the marriage," so runs the account in the published Mémoire, " the family betook itself to Marignane. They made an excursion to Berre to see the salt works. They returned in the evening. During the day, M. de Mirabeau committed acts of violence upon a third person the details of which are suppressed." From Mirabeau's reply to this charge, it is evident that this was one of the unique occasions in his life when he became intoxicated. Drinking and gambling cannot be numbered among his vices. His answer was at the

- Lettres originales de Mirabeau, i., 3 I 4.

- Interrogatoire de M. Gabriel Honoré de Riquety, Comte de Mirabeau, May 9, I774. Archives nationales, Y, 4991: "Mon oncle avait daigné combler Madame de Mirabeau des présents." Loménie, ii., 89.

'Observations sur un libelle diffamatoire etc. (Aix, I 783), I28-г 30. 
same time an explanation, an extenuation, and an apology.

This third party [he replied] was M. de St.-Césaire; this valorous officer that was killed in the service of the king; he lived and died my friend. It is certain that I did him a wrong, the wrong of intoxication; for I was intoxicated that day and many others were also. . . . But the noble soldier that you cite here, and who tied the knot that he believed formed under better auspices [he acted as the representative of the marquis at the signing of the contract], would be very much astonished to see himself figure in a libel or Memoire for divorce under the pretext of a vivacity for which I made my excuses to him at the very moment and that a quarter of an hour afterwards he had forgotten in my arms.

The Mémoire also reports that the same evening, on the return to Marignane, Mirabeau "feigned sickness and announced that he would pass the evening in his room." His wife followed him there and had supper brought. "The quiet was soon troubled by injuries and ill treatment." The cries of Madame de Mirabeau attracted the peasants to the spot and they fetched the Marquis de Marignane, "who called several times to his daughter and ordered her to open the door of the apartment. M. de Mirabeau, who had recovered his senses at the voice of $M$. de Marignane, prayed his wife to do nothing and to reply that it was all a joke." . She did as he wished and "dissimulated everything."

"Shortly after this, M. de Marignane took the young people to Tourvès to visit M. le Comte de Valbelle. It would be difficult to recall all the excesses of which M. de Mirabeau was guilty at this time towards his wife and which were known to all that inhabited the cha- 


\section{The Marriage of Mirabeau}

teau. Everywhere where the two were together, third parties were witnesses of distressing scenes. Madame de Mirabeau was habitually exposed to injurious reproaches, to blows, to outrages, to buffets, and violences of all kinds."

Mirabeau makes light of all this in his reply and doubtless with reason; in her suit for divorce, Madame de Mirabeau seized upon everything available and often made much out of little. There is, however, probably some truth in all these charges. Mirabeau, undoubtedly, did have scenes with his wife and it is quite possible, judging from what we know of his character, that he was violent at times. ${ }^{1}$ It is true that they were nothing but passing storms, such storms as naturally pass over Provençal households and leave no trace behind them.

"One of the quarters of his honeymoon" Mirabeau passed at Hyères in a chateau belonging to his father. "The place is very attractive," wrote a former occupant,

1. A stanza from a song sung at Aix, 1783 , at the time of the lawsuit between Mirabeau and his wife, gives the popular idea of his character and of their relations:
Quand pour son Emilie
Mirabeau soupirait,
Il crut que pour la vie
Sa femme l'aimerait.
Brutal de temps en temps,
Mais bon diable du reste,
Il prodiguait au même instant
Les coups, les baisers, les serments.
Cette conduite est leste.

I found a copy of this song among the manuscripts of M. Paul Arbaud at Aix en Provence.

Mirabeau acknowledged that once, at least, he struck his wife. In 1779 , he denied that he had ever beaten her, " un seul soufflet excepté qu'elle avait bien mérité; car on ne dit pas à son mari, que sa mère et sa sæur sont des putains; mais, enfin, je ne me pardonne ni excuse le coup. "-Lettres originales de Mirabeau, iii., 355. 
"and is situated ouside the city walls within reach of the most agreeable promenades." Jasmine, with its white fragrant flowers, clothed one side of the house, orange trees grew in the garden, and the air was sweet with the scent of violets. ${ }^{1}$ The bailli, describing the house to his brother, who had bought it without seeing it, exclaimed, "I have never seen a little fairy palace that was more graceful." After describing the house in detail, he concluded: "Now I must tell you that the view from the two southern chambers is enchanting; the isles, the sea, a canal, the fields, the woods, the mountains, charming houses, frightful solitudes, barren rocks-in a word, imagine what you will, you will see it there and the whole gilded by an admirable sun, a perfume of oranges." 2

With the marriage of Mirabeau, the "critical year" of his life-as M. Charles de Loménie has called it-had begun. His marriage was to exert so serious an influence upon the following ten years of his life-in truth upon his whole future-that I have felt justified in presenting all of the fragmentary evidence upon which our knowledge of the event rests. To M. de

1 Mouttet, Notes et souvenirs littéraires. A propos d'une lettre inédite de Mirabeau. This volume is a collection of articles that M. Mouttet published from time to time in the papers of Aix. In the second of these, he refers to a visit to M. Alphonse Denis at Hyères: "M. Alphonse Denis nous apprit en ce moment, que la maison dans laquelle nous nous trouvions à Hyères avait appartenu au marquis de Mirabeau, l'Ami des hommes, et que le comte de Mirabeau était venu passer dans ce chateau, avec sa jeune femme, un des quartiers de sa lune de miel-qui ne fut pas de longue durée." My description of the chateau is taken from the second article, in which M. Mouttet gives a long extract from a letter of Madame Saussure, who occupied the chateau in the winter of 1775 , to the queen of England.

2 Correspondance générale, v., 470. The bailli to the marquis, Mirabeau, August 22, r 768 . 


\section{The Marriage of Mirabeau}

Loménie, the evidence indicates that Mirabeau was

advantageously established and had one foot in the service through his rank of captain of dragoons. $\mathrm{He}$ was in a position-thanks to the credit, still real, of his father and to his own personal talents-to have a regular and brilliant career in one of the ways open to the activity of young people of his birth. It remains for us to examine by what succession of faults and misfortunes this young man, making his début in life under the most favourable auspices, became a "déclassé" in the full sense of the word, disavowed by the society to which he belonged, suspected by all, and condemned, in the grand revolution that was preparing itself, to the rôle of "agitator."1

I have quoted M. de Loménie at length, because I do not draw the same inferences from the evidence. I have tried to make clear what Mirabeau's relation was to the army; he was simply captain of dragoons, en suite, not holding office in any regiment, and the commission was made out but not delivered. It will also be recalled that his father had tried in vain to obtain a position for him, and had given up in despair. $\mathrm{He}$ was unwilling to purchase a regiment for him, ${ }^{2}$ doubtless because he could not afford the outlay of money that it would necessitate. I am unable to see that the evidence indicates that there was any career open to him either in the army or in the diplomatic service. As to the other statement, that he made his "début in life under the most auspicious circumstances," I cannot see that it is borne out by the evidence. It appears

1 Loménie, iii., 90.

2 "Mon père, qui a toujours voulu m'ôter du service, m'a empêché, depuisque je suiscapitaine de dragons, de rejoindre aucun régiment." -Lettres originales de Mirabeau, ii., 200. 
to me, on the contrary, that his condition at the time of his marriage and the action of his father toward his existing debts were such as to render financial disaster almost if not quite inevitable. That the recklessness of Mirabeau after marriage rendered the situation much worse than it was, will be shown in the following chapter, but I wish to make clear that he did not create the situation. Mirabeau's own statement concerning his financial condition at the time of his marriage corresponds with such evidence as I have been able to discover:

The revenue that you had assigned me [he wrote to his father] was 6000 livres. M. de Marignane gave me 3000 livres, of which I was obliged to render to his mother one hundred louis for board, and not two hundred pistoles, as you have been pleased to state in print. I had, then, 6600 livres to meet the marriage expenses, that I had not been able to avoid, to clothe myself, my wife and my servants [and he might haveadded that he had agreed in the marriage contract to give his wife 1500 livres annually for this purpose], to pay the interests of my debts, to make the presents customary in the society of Madame de Marignane, and to live a year. I beg you to ask yourself if I could help contracting debts. ${ }^{1}$

$\mathrm{He}$ did so, he himself acknowledges, to excess. That Mirabeau would have run into debt, even if he had begun his married life free from debt and with an income sufficient to allow him to live at Aix in a manner befitting his rank, is not at all improbable; that he had contracted debts that for the most part were inevitable, and that his income was not equal to the reasonable demands that might be made upon him, is what the evidence appears to me to show.

${ }^{1}$ Lettres originales de Mirabeau, i., $3 \times 5$. 


\section{The Marriage of Mirabeau}

Not enough stress has been laid upon the financial relations between Mirabeau and his father. From his youth to his death, the Marquis de Mirabeau was in debt. Financially his own marriage was a failure, and at the period that we have reached in the life of Mirabeau he had not only not realised much from it but he was threatened with a loss of all the property that his wife was to have brought him and with an accounting for his past administration. If his wife should win her case and secure a divorce, it would mean bankruptcy for him. His expenses were in excess of his resources, in spite of the fact that he received a large sum annually from the bailli. Hard pressed as he always was for ready money, it was quite natural that he should be angered by the knowledge that his son had contracted debts, even though he had not contributed as liberally as he should to the son's support. The failure of the marquis to pay his son's debts and to supply him with a larger revenue was not due wholly to his dislike for the young man; he probably did for him all that he could afford to do, but it is, nevertheless, true that it was not enough. Mirabeau had "great expectations," but meanwhile it was necessary to live. That he failed "to make both ends meet" is not surprising. It is doubtful if the marquis would have done better under the same circumstances. 


\section{CHAPTER XIII}

\section{EXTRAVAGANCE, DEBTS, AND A CRITICAL SITUATION}

$\Upsilon \mathrm{H}$

HE days of the honeymoon were soon over and Mirabeau and his wife took up their residence at the chateau on the Durance before going to Aix for the winter. ${ }^{1}$ The bailli was no longer there, having gone to Mont-Dore, previous to his departure for Malta. ${ }^{2}$ His absence at this time was a great misfortune and later the cause of expressions of deep regret on the part of both uncle and nephew. 3 There is no indication, however, that the young couple anticipated their coming misfortunes. The life in the chateau during those autumn months was a busy and outwardly, at least, a happy one. The Marquis de Mirabeau was extremely pleased with his new daughter as he knew her through her letters. He regretted that the bailli could not have enjoyed the letters that she wrote on arriving at the old home. "She shows much wit," he wrote, "is ingenuous, subtle, and sensible, and above all she has infinitely good taste, for she has put your tapestry in the hall in place of the gilded leather. In

2 A letter of the marquis of August 10,1772 , refers to them as being at Mirabeau.-Correspondance générale vii. 10, quoted by Guibal, i., ro3.

2 Guibal, i., 103.

3 "Mais je gémirai le reste de ma vie de n'être pas venu en Provence lors de son mariage." - Correspondance générale, ix., 569. The bailli to the marquis, Mirabeau, May 26, I78I. Guibal (i.,104) refers to a letter of Mirabeau to the Comtesse de Vence, May 3, I 774. 
fact, her plan appears to me well thought out. She showed, at the very first, great interest in this large, noble, well built house and then the air is fine! She had so much desired a place from which she could look down and a chateau which dominated the village." The marquis repeated with evident satisfaction the words in which the countess expressed her delight in the old home. "Our fool," he continued, "swallows that, hunts, exerts himself, and assures me that, except in the case of confinement, they will leave there only when I drive them out. You may well imagine that I contribute, to the best of my ability, but adroitly, to their pleasure in finding themselves alone and his letters are much more orderly and regular. In short, I hope for everything, if this young woman is not taken ill." 1

"As to your niece Mirabeau," he wrote to his brother a week later, "you will love her too much when you have read her letters. She has a mind that is lively, gay, pleasant, and very sensible. She works like a demon. ... Her husband is also much more exact and regular with his letters. She wrote to me, We are running after order and we hope to catch it. They give their servants money in place of bread and wine. She says they live very cheaply, thanks to the game. She is, furthermore, ailing and enceinte. But, in truth, she is a pretty child." 2

The Marquis and the Marquise de Marignane were not less interested than the Marquis de Mirabeau in the young household. In response to an invitation to visit the chateau, the marquise assured her son-in-

1 Correspondance générale, vii., I8. The marquis to the bailli, Paris, September I, 1772 .

2 Ibid., vii., 25. The marquis to the bailli, Paris, September 6, 1772. The report that the countess was enceinte proved to be premature. 
law that "it was just what she desired, as it contained all that was dear to her." The marquis had heard of the young people at Marseilles. "You amused yourselves there," he wrote. "That is capital. The finances must adjust themselves to these little jaunts, when we have a desire to take them, and not we ourselves to our finances. It is all the same at the end of the year; I mean, it is all the same, if, after you have been brilliant, lively and run about for one month, you know how to keep quiet during eleven." 1

This bit of philosophy was lost on Mirabeau. It was the very thing that he did not know how to do; and, in truth, he never learned. His conduct in money affairs was marked by "a lack of foresight truly infantile, by a penchant for squandering that did not disappear with his youth." He conducted himself as if the property that was to come to him with the death of his father were already in his possession. His manner of life was not conditioned by his limited income, already consumed in advance, but by his conception of what was in keeping with his own rank and with that of his wife. He wished to "make amends to her for the privations that the smallness of his income prepared for her." 2 She did not, however, experience these privations so long as Mirabeau's credit lasted. He gave to his wife, he asserted later, "the most exquisite things; I doubled her diamonds; she found repeatedly the most charming robes, made without

1 Guibal (i., r04), where the letters are quoted. They bear the dates of the $22 \mathrm{~d}$ and 24 th of September.

2 Interrogatoire of Mirabeau at Manosque, May 9, I774. The original is in the Archives nationales, Y, 4991, with the other documents relating to the interdiction. The interrogatoire and some of the accompanying documents have been printed by M. Alfred Begis. See Critical Bibliography. 


\section{Critical Situation from Extravagance}

her knowledge; the most tender lover could not have carried farther this kind of attention towards his most cherished mistress." 1 "Although Madame de Mirabeau had, by the terms of her marriage contract, but I 500 francs allowed her for her personal expenses, the bill of a single dealer for veiling, ribbons, lace and other finery, from the first of August, I 772, to the first of June, I773, amounted," so Mirabeau claimed, "to I 600 francs." 2 Mirabeau's own wardrobe was singularly rich and contained, according to a statement dating from I 774, thirteen complete suits, of all kinds of material and of the brightest of colours from celestial blue to soft rose. 3

The apartment in the chateau called the "gilded chamber," "already antiquated in the time of his venerable great-great-grandmother, Anne de Pontevès," 4 Mirabeau had rejuvenated that it might be fit for his wife. Skilled workmen were brought to the chateau and the transformation began. The height of the room was increased, it was wainscoted, and gilded. "Drawn on from one ornament to another, I had expended 20,000 livres," confessed Mirabeau, "where

1 Lettres originales de Mirabeau, i., $32 \mathrm{I}$; Observations sur un libelle diffamatoire (Aix, $1_{7} 83$ ), r40. In writing the Observations, Mirabeau reproduced literally portions of the Mémoire addressed to his father from Vincennes and printed in the Lettres originales de Mirabeau, i., 287-436.

2 Observations, etc., 14I, note. On the same page, Mirabeau writes as follows about the sums expended for his wife: "Je dirai au public que je puis prouver par les mémoires et quittances des 36,000 livres que j'ai payées sur mes dettes, que Madame de Mirabeau, qui n'a resté qu'un peu plus de deux ans avec moi, s'y trouve, quant à sà dépense personelle, pour une somme de 22,600 livres."

3 Loménie, iii., ro2, note.

- Montigny, Mémoires de Mirabeau (ii., r6), quoting from a letter of Mirabeau to Madame du Saillant of November I4, 1772. 
I had intended to employ a thousand écus."1 And the room was not yet finished. The bailli expressed the opinion, some years later, that it could not be completed for six thousand francs. The feelings of the uncle on viewing the elegant apartment may easily be imagined. "The folly of this crazy fellow," he wrote in July, I 777, to his brother, "in wainscoting and gilding the only chamber where there are closets, has inconvenienced me much, for I shall never have the courage to inhabit a chamber that resembles the salon of the Duc de Nivernois, and which deprives the chateau of two chambers that were above." 2 At another time, he talked of "detaching the wood and selling it, for this chamber is too beautiful to inhabit; one would always be afraid of spoiling it." But, at the same time, "it would cost three times as much to restore this apartment to a reasonable condition"; and yet he is not certain "that it is proper, in a chateau like that, to have a gilded rat's nest." 3

The furniture of the chateau was antiquated and worn and I 5,000 francs found their way-in the form of promises to pay-into the hands of furnishers. $4 \mathrm{~A}$ part of this expense was met by the six hundred francs obtained from the burning of the dilapidated gold galoon taken from a red damask bed, too old and tarnished to appear to advantage on the new furniture. ${ }^{5}$ The chateau was not easy of access and Mirabeau, wishing to give himself the pleasure of conducting his

1 Interrogatoire, Archives nationales, Y, 499x.

2 Correspondance gentrale, vii., 405. The bailli to the marquis, July $4,177 x$.

3 Ibid. (vii., 405, 414, 429, 454), quoted by Mouttet, Mirabeau en Provence, iv., 2.

' Interrogatoire, Archives nationales, Y, 499r.

s Ibid. 


\section{Critical Situation from Extravagance}

wife there in a carriage, began the construction of a long avenue through the solid rock. ${ }^{1}$

These affairs consumed but a small part of his time. He concerned himself seriously with the administration and improvement of the estate, possessing all the genius of his father in the conception of schemes of remarkable promise. "Placed at Mirabeau between a chaplain, a steward, and a farmer, enemies of one another, he was drawn by the chaplain into lawsuits, by the steward into compromises, by the farmer into enterprises that aggravated his personal position, increased his debts, and ended in the displeasure of his father." The chaplain, steward, and farmer were in correspondence with the marquis. Their reports upon the acts of his son were decidedly contradictory. "His lawsuit with the communities," wrote the steward Boyer, "will ruin the income from this estate and the discipline of the vassals"; to the Abbé Castagny "his compromise was a false step, an act of dangerous feebleness," to Boyer it was a "master stroke." In September, 1772 , the chaplain wrote to the marquis: "M. le comte has the misfortune of refusing good counsels and accepting bad ones; he gives himself up to uncertainties and to the incense of flatterers, who breathe into his ear beautiful projects, that cut out work for him for a long time, excusing himself later on the ground of his imperious character." At about the same time, another farmer, M. Thabot, wrote to the marquis that "with an advance of 30,000 francs, M. le comte could clear all the land, obtain great returns, and check the ravages of the Durance." 2

1 Loménie, iii., 102.

2 Montigny, Mémoires de Mirabeau (ii., I 7, 18), where the letters are quoted. They were written between September, 1772 , and February, 1773; that is, if the dates are correctly given by M. de Montigny, a thing of which one can never be certain. 
The time that was not consumed by such serious affairs Mirabeau gave to hunting, ${ }^{1}$ to the company of his wife, to visits to his neighbours, and to the entertainment of those who came to the chateau. He kept a carriage, that he graciously placed at the disposal of his friends and relatives. ${ }^{2}$ "His hospitality was liberal, generous, and popular; he considered it a duty to offer a glass of wine to the peasants that came to see him and to dine his neighbours and passing travellers." 3 Accompanied by Madame de Mirabeau, he frequented the chateau de Grandbois, inhabited by his cousin $M$. de Roquessante; he visited the manoir des Jourdans, the residence of another cousin, M. de Limaye, and was the guest of the Ailhauds at Vitrolles.4 Of the details of this life, we know but little. A happy accident has preserved for us three letters written, one by Mirabeau and two by his wife, to his cousin Madame de Roquessante. ${ }^{5}$ Treating of a little unpleasantness that arose between Mirabeau and his cousin, they reveal something of the relations existing at the time between Mirabeau and his wife, and throw some interesting light upon his character.

1 Correspondance générale, i., 32. The bailli to the marquis, Aix, July 6, i $78 \mathrm{r}$.

2 Letter of Mirabeau to M. de Roquessante, without date. Collection of M. Paul Arbaud: "S'il m'est impossible de m'eloigner d'ici la semaine prochaine, qui précédera un voyage nécessaire, mon cabriolet, au moins, sera aux ordres de ces dames, et j'espère qu'elles nous feront la faveur d'en profiter."

${ }^{3}$ Guibal (i., 106), quoting from the letters of the marquis and the bailli for $I 78 \mathrm{I}$ and $\mathrm{x} 782$.

4 Mouttet, Mirabeau en Provence, 67.

3 The letters are given in Mouttet, Mirabeau en Provence, 75-80. The originals are in the possession of M. Garcin of Apt en Provence. Mirabeau's letter bears the date of August 23, 1772; the first by his wife is not dated, but was probably written the last of August; the second is dated September I 2, 1772 . 


\section{Critical Situation from Extravagance}

The incident that gave rise to the letters occurred in August, 1772 , at the chateau de Vitrolles, whither the three had gone in the carriage of Madame de Roquessante. It appears that they had previously agreed that, giving as a pretext the fatigue of Madame de Mirabeau, they would leave Vitrolles on Saturday. So great, however, was the insistence of their hosts that they should remain, that the count and his wife considered it due to politeness to yield. Madame de Roquessante, however, was much disgusted, and suspecting, from an expression that the Baron de Vitrolles let fall, that Mirabeau had concerted this concession with him, became furious, ordered her carriage, and departed brusquely. Immediately on her return to Grandbois, Madame de Roquessante wrote to Mirabeau a very impertinent letter. His reply was a chef d'cuvre of malice, the earliest example that we possess of that cutting sarcasm that he displayed so often in the national assembly:

When one knows how to make as fine apologies as yours, Madame, it is quite natural, that one should find pleasure in doing so; for myself, as I am not conscious of possessing a talent for that sort of thing, I shall not contend against so amiable an accuser and shall confine myself to saying:

That nothing has changed nor will change the gratitude that has been inspired in us by the manner, affectionate and full of kindness, with which you have honoured us;

That the fatigue of my wife was only the honest pretext that I was to make use of in dealing with $M$. and Mme. Vitrolles;

That I made an engagement with you as to the return upon Saturday, only at Vitrolles, where you offered as pretexts two reasons equally good, your wish and the desires of my wife;

voL. I- 22 
That, without too great nobleness of soul, I believed it possible to imagine, that the manner, affectionate and full of kindness, of the Vitrolles family, of which you were the object as well as ourselves, could lead us to change our minds;

That the desire, very marked and very evident, of my wife had some weight with me;

That I was changing my shirt (pardon the triviality of the expression, but I can call things only by their names) when you departed;

That I did not doubt that you would have yielded, not being acquainted with the full energy of your soul in matters of this importance;

That M. le Baron de Vitrolles imagined the expression that I am supposed to have addressed to him;

That it never entered the mind of my wife that my glory could be interested in a woman's quarrel, and she has had the good sense to compromise herself in it as little as possible;

That I had feared that I had noticed even before you that, by a very real misfortune, apparently attached to my star, we were not entirely at ease when together;

That I am very thankful for the exclusive esteem that you have been good enough to bestow upon my wife, whom I also esteem because she is civil and not a mischief-maker;

That she has the happiness (for it is such for a civil woman) to set much store by her husband; and that she is so fearful of losing this blessing, that she appreciates equally with the flattering friendship that you show for her, that I see she is very much disposed, without using upon her the right that tyrants have over their slaves, not to run any risks in this matter;

There, Madame, is all that my limited fecundity permits me to say to you, adding, however, that I have known for a long time that it is permitted to a woman to say everything and not to understand all the meanings of words. 


\section{Critical Situation from Extravagance}

From the first letter of Madame de Mirabeau, written evidently the last week in August, it would seem that she placed greater store by the friendship of Madame de Roquessante than the letter of the count would lead one to think.

I am very much afflicted [she wrote] at all the little differences that have arisen between my husband and you. . . My husband has shown me the letter that you wrote to him. He appeared to me a little piqued, some of the expressions that he found there having offended him. He showed me also his reply, where, after a fashion, he justifies hinself in his own way; I noticed, also, that he fell back upon me somewhat. But that cuts no figure; as I know your discernment, I am not fearful that you will not give to each one his due. I am very much pleased, though, that he endeavours to excuse himself. For, my dear cousin, you cannot deal with him as you would with another man. With a character like his, it is necessary to make an allowance of a hundred per cent., because one is sure that the foundation is good. For myself, I am so much the more concerned that you should accept his excuses as good, as with a husband a little despotic, I should see myself deprived by this quarrel of the most agreeable neighbour that we have. For my husband would never give me permission to go where he could not go, and when he has once made up his mind, it would be simple folly to attempt to combat him.

I believe [concluded the countess] that the way to finish all this would be to reply in a humorous vein to my husband (to whom you have, furthermore, written the truth) and all will be ended. What would you, my dear cousin? One should not try to draw from a piece of ground more than it can render.

It was quite natural that the young wife should not wish her husband to see this letter. With the con- 
cluding injunction to burn it after it had been read, it was delivered into the hands of the cook of Madame de Roquessante, who waited for an answer. The secret correspondence between the two women, who employed their cooks as messengers, went on. The rath of September Madame de Mirabeau wrote that the day before, some one having said in the presence of her husband that she was to receive a letter the next day from Madame de Roquessante, he declared that he would see it. The letter arrived, passed from the cook to the chambermaid and then to Madame de Mirabeau.

I have not shown your letter to him [she wrote to Madame de Roquessante], it is still (permit me to say it, dear cousin) much too sharp; a further reason was that the first, which did not appear to me at first sight very severe, was considered insulting by several persons to whom my husband read it (not of Manosque). This confirmed him in the idea that you had treated him ill. Several persons said to him that that of which you accused him did not merit the reproaches that you had addressed to him; such as playing with the truth, of being a man whom you esteem lightly, etc., etc. All that has fermented in his head. [One phrase of her letter, in which she said that the avowal that Mirabeau had made that he felt ill at ease in her presence was the most flattering compliment that he could have paid her, would have cut him to the quick.] So [continued the countess] I concealed my letter, and contented myself with saying to him: "But perhaps my cousin wrote me to know if we were going to Beaumont, and perhaps she thought we might have forgotten." "In that case," he replied to me, "you will say to her that she has only to testify the desire of it to me and I shall not hestitate to do what she wishes; but you have nothing to do with this affair."

Those are his own words, dear cousin. I believe that a 


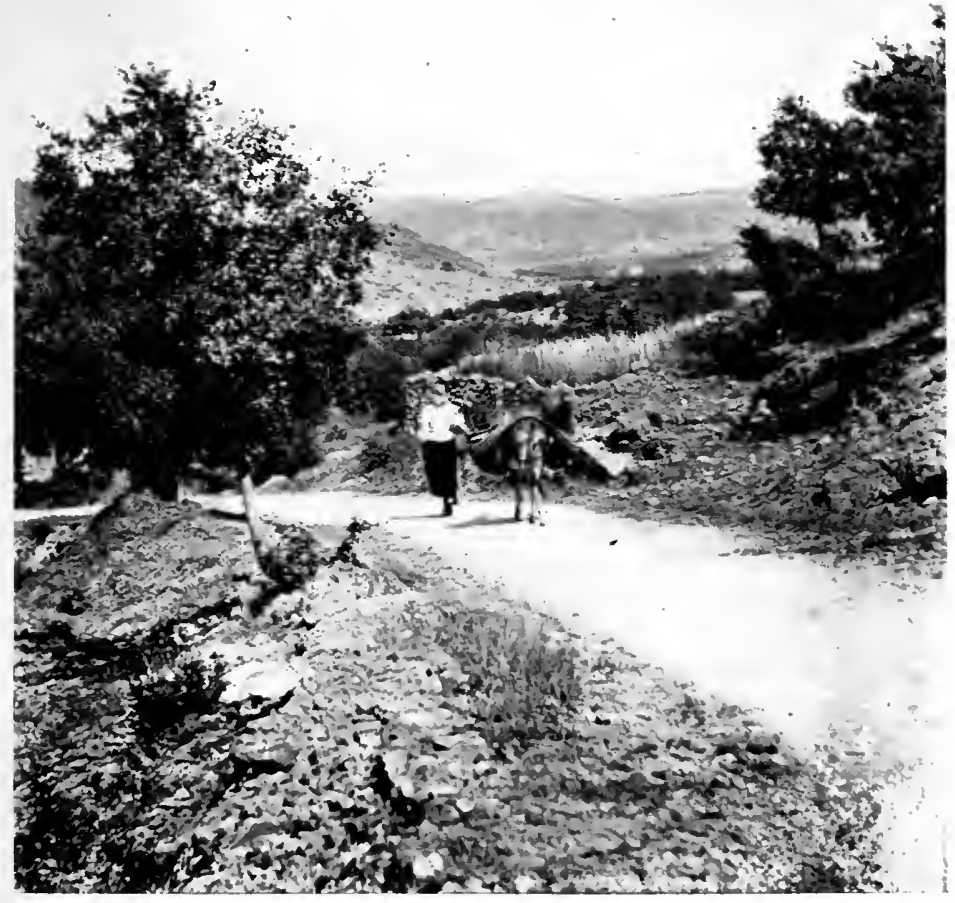

Looking East from the Chateau de Mirabeau From a photograph by H. D. Fling 



\section{Critical Situation from Extravagance}

friendly word from you to my husband, an expression that made no reference to what has passed, would end all and at once; and this would be a great pleasure for me, who am sensitive to the great worth of a lovely neighbour like yourself, and of a relative who does me so much honour in every way and by the manner in which she has always conducted herself; a thing that makes a companionship very precious for a woman who is making her début.

Here the evidence ends, and, doubtless, the incident also. Two of the traits of Mirabeau's character are brought out by the correspondence: his pride that made him quick to resent insulting language or a patronising attitude, and his readiness to forgive and forget injuries. It was undoubtedly this self-sufficiency and pride that caused much of the misunderstanding between himself and his father; the latter trait is one of the most admirable in his character.

Something more serious than a "woman's quarrel," as Mirabeau called it, was already beginning to disturb the peace of his household. Not many months had passed before he began to realise the impossibility of living any length of time on promises to pay. The history of his debts antedated his marriage. It will be remembered that he had contracted debts while on

1 On the same date as that of her last letter, sent secretly to Madame de Roquessante (September I2, I772), the countess wrote a second letter, evidently with the knowledge of her husband: "Je voudrais bien, ma chère cousine, qu'il entra dans les projets de mon mari, ou que ses occupations lui permissent, d'aller demain à Beaumont, puisque j'aurai le plaisir de vous y voir. Il partagerait, certainement, ma satisfaction; mais il est entouré d'affaires qui se multiplient tous les jours; plaignez-vous, donc, des obstacles du hazard et rendez plus de justice à M. de Mirabeau, qui n'est pas d'assez mauvais gout pour s'ennuier chez vous, et lorsque vous le recevez avec bonte." The original is in the collection of M. Paul Arbaud, Aix en Provence. 
the Ile de Ré and also during the campaign in Corsica. His allowance from his father had been small-at least so he asserts, and the treatment received from his father in later years gives some support to the assertion-and he had supplemented it by sums secretly received from his mother. He had always spent his money freely and it is quite probable that he would have contracted debts, even had his allowance been extremely liberal. "You will note," he wrote to his father from Vincennes, in $\mathrm{I77}$, "that at the age of twenty years I had not had in my possession the smallest piece of money, unless I had received it from you; that during the thirteen months that I was in Corsica, where I took part in a campaign, you did not allow me to touch I800 livres; that the allowance that you assigned to me afterwards was never exactly paid." 1 Some of the debts were still unpaid in 1772 . On his way to Provence in $177 \mathrm{I}$, he contracted debts at Lyons. All of these debts, he claims, his father had knowledge of and that he had been pardoned for contracting them. It would not be wise to take these assertions of Mirabeau too literally, but, on the other hand, to exaggerate the amount of his debts before marriage, and conceive of him as a spendthrift occupying a unique position among the young noblemen of his day, would be equally unjust and would falsify the reality. It would be well to keep in mind the observation of the bailli upon this very matter, made to his brother in 1778 : "To tell the truth, the youth have set such a pace in this respect, that Bailli Despennes, who as the king's man, was the intelligence office of three fourths of the parents of our youth [at Malta], said to me that there was almost no one that did not owe large sums of money when the time came

1 Lettres originales de Mirabeau, i., 3 I3. 
to leave Malta. You know the rôle that it plays at Paris; it is pretty nearly the same everywhere; and if we were to imprison all the young men that are in debt, we would see only greybeards on the streets." 1

"I had reached Aix," wrote Mirabeau in the Mémoire to his father, "with one suit of clothes and money enough to pay my travelling expenses; it was necessary to clothe myself with decency and even with elegance." There would have been little possibility of succeeding in his suit for the hand of Mlle. de Marignane without a lavish expenditure of money both for dress and for other purposes. "The very delicate and very complicated intrigue, by means of which alone my marriage could be made a reality, entailed some expense; to consider the thing only from the point of view of economy, it was certain that in the case of my success, it would be putting out my money at very large interest."2 To meet these expenses, he claimed that his father's agents had not advanced twenty-five louis. Then followed the expenses attendant upon the marriage contract and the wedding. "I can prove," Mirabeau said in an official statement concerning his debts made

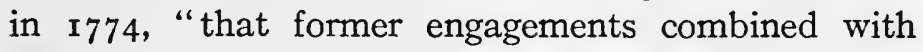
those of the moment surpassed the sum of 50,000 livres." 3 His statements concerning how much he

1 Correspondance générale, viii., I75. The bailli to the marquis, Aix, April 24, 1778.

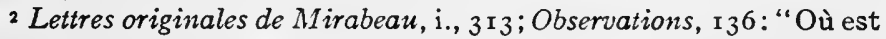
le jeune homme qui n'aurait pas outrepassé une très modique pension, surtout quand une fortune considerable paraissait l'attendre? Surtout quand les circonstances le plaçaient dans la societe des gens riches, le conduisaient à la recherche d'un des plus grands partis de la province, et dans un pays, qui, quoique la patrie de ses pères, ne lui offrait plus la maison d'aucun grand parent pour hospice."

${ }^{3}$ Interrogatoire, Archives nationales, Y, $499 \mathrm{I}$. 
owed after his marriage are difficult to reconcile. In the letters from Vincennes, he wrote in 1778 : "I call M. de Marignane to witness that I declared to him before signing the articles that I owed about four or five hundred louis, and that I represented to him how important it was to be free in order to be able to adjust myself to my very modest income. He regarded this debt as a bagatelle and he was in the wrong." 1 If these figures are correct, the marriage contract and the wedding, including the presents, must have cost some 38,000 francs. This is, of course, not impossible, as the expense of the contract was more than a thousand francs, but not probable. In his Observations, published during the lawsuit with his wife in 1783 at Aix, Mirabeau makes use of the passage quoted from the letter from Vincennes, but with very important modifications: "I call M. de Marignane to witness that I stated to him before the signature of the articles of marriage that I owed about Iooo louis (the italics are my own) and that it was infinitely important that I should be freed from them, that I might be able to adjust myself to my very modest income. M. de Marignane did not doubt for a moment that they would not consent to pay them. He deceived himself." 2 Here the debt has doubled in size. The reason for this change is self-evident. By increasing the amount of his debts before marriage, for which his father would seem to be responsible, Mirabeau reduced the amount of the debts after marriage and rendered himself less liable to the charge of careless extravagance. This was a matter of some moment at the time of the lawsuit.

Before his marriage, Mirabeau had turned to the

1 Lettres originales de Mirabeau, i., 3 I2.

2 Observations, 136. 


\section{Critical Situation from Extravagance}

Jews for assistance. "Shortly before my marriage," he wrote to his uncle in $x 780$, "pressed for money, I had recourse to Daniel Beaucaire." 1 He borrowed one hundred and fifty louis. Beaucaire asked for an indorsement, and proposed Mirabeau's cousin, M. de Limaye, "who had dealings with the Jews every day." Mirabeau hesitated, but Beaucaire assured him that it would be agreeable to Limaye. A note for five hundred louis was made out for six months. Limaye received one hundred louis. Mirabeau had an understanding with Limaye that at the end of six months the note should be taken up and other arrangements made without an indorser. According to the letter, the note was remade at the expiration of the time and Limaye's note was returned to him. This does not agree with a statement made by Mirabeau to Limaye himself, in a letter written in 1774 . "At the time of my marriage," he then wrote, "I asked for your indorsement on drafts to the amount of I 2,000 livres; six months later I extended the note for 6000 for which I did not ask your indorsement. You were not responsible, then, for more than 6000 livres, a sum the demand for which could not, in any case, be ruinous." 2 This last statement is probably the correct one.

From his father, Mirabeau received little assistance. In June, I772, the intendant Clapiers wrote to the marquis: "I paid his note for 200 écus; the sum, if I may venture to say so, was a very small one in view of the great expense." The next month, the marquis

1 Correspondance générale, ix., 352. The count to the bailli, Vincennes, August I 8, I $_{7} 80$.

2 Letter of Mirabeau to M. de Limaye, dated at Manosque, April 14, r774. I have made use of M. Mouttet's copy. The original is in the collection of M. de Montigny. 
wrote to him "that he does not see any statements of further payments made for his son," and in August he wrote "that he did well not to acquit his son's debts without an order from him" and asked if a certain draft had been paid. ${ }^{1}$

This was, certainly, a sufficiently critical situation for a young man with an income of only 9000 francs a year. The interest at five per cent. on 50,000 francs would have consumed nearly one third of his income, leaving him only about 6000 francs to live upon. Of this, I 500 was allotted to the countess for her personal use. How Mirabeau lived during three months after his marriage I have already shown. Meanwhile, his debts had more than doubled. In the hope of finding some relief he addressed himself to his mother, in October, I 772, proposing to her that she league herself with him, he did not venture to say against his father, but against M. and Mme. du Saillant. ${ }^{2}$ At about the same time he wrote a most affectionate letter to his sister. One is reminded of the saying of the marquis concerning his son: "To be if necessary ape, wolf, or fox is all the same to him, for nothing costs him anything." 3 Such a spirit might easily be developed in the home environment that has been previously described. To these advances, his mother made no reply. At about the same time, Mirabeau endeavoured to

1 Archives nationales, M, 783 , No. 17. These are jottings of the contents of letters sent to the intendant. The dates of the entries are July 25 and August 9, $\times 772$. The quotation from the letter of Clapiers is found in Montigny, Mémoires de Mirabeau, ii., r3.

2 Loménie (ii., $57 \mathrm{r}$ ) gives the letter in full. The date is October 8.

${ }^{3}$ Ibid. (ii., 575) gives an extract from the letter: "Crois que mon amitié ne cédera jamais à la tienne, et que, s'il n'est pas de meilleure sœur que toi, il n'est pas de plus tendre frère que le tien. Embrasse pour moi ton mari." The date of the letter is September 23, 1772 . 
obtain relief from another source. The initiative in this matter he attributes to his father-in-law: ${ }^{1}$ " $\mathrm{My}$ father-in-law wished to lend me a helping hand. $\mathrm{He}$ had pledged himself, in the marriage contract, to give me 20,000 écus at a certain epoch, that may heaven postpone for a long time. He was desirous of advancing this sum to liquidate my debts, that such a sum would have paid and more too at that time. $\mathrm{He}$ wished, I said, to advance this sum to me on condition that my father would give his receipt for it; for my father is the only one who by the clause of the marriage contract could receive my dowry." His father refused his signature. "He was led to believe that in according it, he would encourage me to begin again. It would have been more correct to say that he would have invited me through indulgence to follow a more orderly course, would have taken from me every excuse in case of a relapse and have put me to an infallible test." His father did offer 18,000 francs to M. le Comte de Grasse de Bar to pay his son's debts, but Mirabeau refused the offer on the ground that it was not sufficient, that his revenue would be consumed by the interest on what remained and if, as was inevitable, his condition grew worse it would be said, "His debts were paid and he began again." 2 This was the situation when he went to Aix in the winter of 1772 and took up his

1 According to M. Guibal (i., ro6, note 9), who refers to a letter of the countess and a "brouillon, rédige par le comte de Mirabeau, d'une lettre que la comtesse doit écrire à son père" as proof that the initiative came from Mirabeau. This is probably the truth of the matter.

2 Lettres originales de Mirabeau, i., 317: Observations, 138; Interrogatoire. Archives nationales, $\mathrm{Y}, 499 \mathrm{I}$. The second account is a literal reproduction of the first. The last account, written in 1774 and very brief, contains no reference to the offer of 18,000 livres made by the marquis. There seems, however, no reason to doubt it. 
residence with the Marquise de Marignane, the grandmother of the countess. It was in accordance with the marriage contract.

At the time of Mirabeau's arrival, the nobility of Aix was divided into two hostile camps, the supporters of the old and the supporters of the new parliament. In October, $177 \mathrm{I}$, but two months before he came to Provence on his father's business, the old parliament of Aix, that had refused to register the edict of December, r 770, limiting the powers of the parliaments, was suppressed and the cours des comtes was transformed into a parliament to take its place. Of this new court, M. d'Albertas was the first president. "This change was viewed with indifference by the people, their curiosity alone being excited."

The members of the old parliament were exiled to their estates, but on the request of $M$. d'Albertas some thirty were allowed to return. He soon regretted the sympathy that he had shown towards his predecessors.

I have cause to reproach myself [he wrote to the Prince de Marsan in May, I772] for having requested the recall of more than thirty of these gentlemen, who assemble, cabal, put in circulation disadvantageous reports that frighten the public and tend only to inspire it with a distrust that is harmful to the present business. M. le procureur-general and myself are occupied solely in destroying the falsehoods that they are engaged in spreading. Others than ourselves would, perhaps, have had recourse to legal measures against those that intrigue in such an indecent fashion. ${ }^{1}$

The resentment and the anger that were the outgrowth of this division invaded the home of Madame de

1 Flammermont, Le chancelier Maupeou et les parlements, 464-468. Guibal (i., 108) gives some valuable extracts from the manuscript Journal de nouvelles of the Marquis d'Albertas. 


\section{Critical Situation from Extravagance 349}

Marignane, the grandmother of the Comtesse de Mirabeau and a relative of $M$. de Ripert de Monclar, the distinguished procureur-général of the old parliament. ${ }^{1}$ Mirabeau shared these sentiments. It will be remembered that he was in Paris at the time of Maupeou's coup d'etat and had expressed himself vigorously against the arbitrary act of the government. It was quite natural that he should be found in the party of opposition at Aix. He has himself given an account of his relations with the D'Albertases at Aix in 1773 :

When I arrived at Aix, M. d'Albertas was, as you know [he was writing to his father], first president of the new parliament. In your house I had not acquired a great veneration for these new magistrates. You had reasons, without doubt, for being a friend of M. d'Albertas, but you had not been, surely, a partisan of his usurpation. My opinions in this regard were the same as yours, and I believe those of all honest people. . . . Many of your relatives and friends belonged to the old parliament. A close intimacy with the chiefs of the new company, and even more, if possible, the appearance of this intimacy would have been very indecent in me. I refused all the advances that could lead me in such a direction. The D'Albertases did not forgive me that any more than my intimacy with the old parliamentarians. My marriage, that blasted their sweetest hopes and their favourite projects, did not improve the situation. Meanwhile, everything appeared between us as it ought to be. Madame d'Albertas came from Jumenos to see Madame de Mirabeau immediately after the marriage and returned at once to her country-seat. We received and we returned marked courtesies. Winter came. Madame d'Albertas came back to Aix. Madame de Mirabeau was already there. The wife of the first president claimed the first visit, and I acknowledge that

1 Guibal, i., ro8. 
all the women except the wives of the members of the old parliament, who did not call upon her, rendered it to her; but I do not acknowledge that that was any law for me who was not looking for suppers. Madame la Marquise de Sabran alone had abstained from this singular homage. I believed that I could permit myself a single pretension, that of suffering such a thing in no one. Furthermore, it appeared bizarre to me to have received the first visit from M. d'Albertas when I was a bachelor, and when I was married to send my wife to pay the first visit to Madame d'Albertas. Madame de Mirabeau accordingly remained at home. Madame d'Albertas murmured. I let her murmur. An attempt was made to adjust the affair. I turned a deaf ear. My father-in-law, who did not see those people-it is his expression-approved of my action. Madame d'Albertas felt that, as wife of the first president, her pretensions were ridiculous. In order not to abandon them, she sustained them as aunt à la mode de Bretagne. I laughed at the subterfuge; but I laughed very quietly.

The carnival arrived; the balls followed each other. Madame d'Albertas did all that she could to bring out your daughter-in-law. I replied to the negotiators, that surely if we visited Madame d'Albertas it would be for herself and not for her ball; and thus the occurrence and the argument were both badly chosen. There, my father, are the first seeds of our division. They fermented noiselessly.

My father-in-law was syndic of the nobility and lived at Tourvès during the summer. He charged me to follow together with Gassier, syndic of the robe, the affairs that then were very complicated, and to render him an account of them. There were great discussions between the intendant and the possessors of fiefs, and M. d'Espennes, friend of M. de Marignane and of my uncle, was very much interested in them. M. de Monthion had ravaged the entire administration of the province, that called for union and help from the corps of the nobility. The new parliamentarians caballed with vehemence against us. My father-in-law 


\section{Critical Situation from Extravagance 35I}

struggled vigorously against them in the assembly of the nobility. They pretended that I had helped to warm him up and to support him; a thing of which, certainly, he did not stand in need, for one could not be a better friend nor a better patriot. The opinions were expressed with much solemnity. It happened that my speech made something of a sensation. We triumphed; it was a crime. But finally it was a crime of which I was guilty in common with all honest people. Up to that time, nothing exactly personal had occurred between the D'Albertases and myself. The occasion for it presented itself; here is the blackest of my assaults upon them. Be kind enough to listen.

Madame de Mirabeau was enceinte and much incommoded by her condition. One day she took a chair to the theatre and I followed on foot. The D'Albertases, father, brother, and son, crossed our path almost at the door of the theatre. The street is very steep. The coachman stopped too closely and the carriage dropped back. I instructed him sharply to move on. I had no time to pay compliments, for the chair of Madame de Mirabeau was in danger. The coachman took no notice of my instructions; his wheel rolled upon one of the poles of the chair, that had been set down, and injured a bearer. By the greatest and most singular good fortune, I withdrew Madame de Mirabeau without accident from her chair. All that passed quicker than thought. I acknowledge that terror was succeeded in me by anger. I threatened the coachman; and as I was irritated, very much irritated, that his masters should leave the trouble to me; I repeated, on seeing them on the step of the carriage, my apostrophe to the valet. The entertainment closed without my meeting the D'Albertases, because I distrusted my resentment. The next day, Madame la Comtesse de Grandubar, the aunt of Madame de Mirabeau, requested me to call upon her. I found her very much frightened by a visit that she had just received from the first president. $\mathrm{He}$ complained bitterly that I had addressed to him, to his family and to his 
company (the parliament) an epithet that the porters hurl at one another in the market-place when they quarrel. Were it not for his consideration for you, he said, he would have prosecuted me judicially. You see I had a vast field for retort and even for banter. I contented myself with replying in these words: "My dear aunt, you have probably misunderstood; for both yesterday and to-day I encountered M. le chevalier d'Albertas and his nephew, who have not the gout, and they made no complaint to me." As for the rest, I believe that it would be difficult to persuade any one, that I apostrophised the parliament in the open street because the coachman of the first president is a fool and an impertinent fellow; I abstain from all raillery and all wrath. The whole city spoke to me about this adventure; I replied in the same way to all the city. This uproar died out like so many others. . . . There, my father, is the way in which I wronged them. I was not always so circumspect, I confess. They tried to stir up trouble for me and I extricated myself from it, not, however, without characterising their procedure and revealing its baseness. Then they launched epigrams at me, and as there are occasions when certain persons are always in the wrong, they were not any more successful in this matter than in any of the others. Finally, they made sport of my birth; annotating an article of what is called in Provence the mauvais livre. In all the other matters, I had seen only calumny, very common in this region; but that appeared to me an unspeakable insolence on the part of people that have the honour to be related to me and ought to know that they have brought into this alliance only a very bad reputation and a roture very well known, exalted, it is true, by a few that were hung. $I$ have seen proofs of it, and if the aunt of $M$. de Marignane were not entered in this race I would, perhaps, have been tempted to educate them a bit, by depositing at the chambre des comtes these titles that are not very old. However that may be, after such proceedings, I treated them no longer with consideration and put the finishing touch to 


\section{Critical Situation from Extravagance 353}

their hatred of me. The friendship, and, if I dare to say it, the esteem of Messieurs de Castillon, de Cinq-mars, and de Saint-Vincent, compensated me with usury for the calumny of a cabal for which, perhaps, I did not sufficiently disguise my contempt. ${ }^{1}$

After due allowance has been made for the influence of the personal element upon the value of this evidence, it still remains true that Mirabeau lived at Aix in a state of open hostility with M. d'Albertas and the members of the new parliament. A knowledge of this situation is necessary to properly appreciate the value of the information concerning the conduct of his son, received by the marquis in August, 1773 , from the first president of the parliament of Aix. It is clear from this letter that Mirabeau did not exaggerate when he wrote to his father that he did not, " perhaps, sufficiently disguise his contempt" for M. d'Albertas and his company.

Our attachment and our friendship, my dear cousin, [wrote M. d'Albertas to the marquis] is of sufficiently long date that I may be permitted to confide to you the alarm that I experience on your behalf because of the more than thoughtless conduct of your son and the hazardous remarks that he permits himself to make. The other day a man from Lyons, who was prosecuting the protest of several drafts made out to him by your son, came to me to complain of a denial of justice upon the ground that no procureur would accept the request that he wished to present tending to the prosecution of the Comte de Mirabeau, who, as payment for his drafts, had showered blows upon him. As it is my duty to render justice and as this stranger asked it of me, I assigned him a procureur. My cousin called at once upon the procureur and poured out upon him threats and insults

1 Lettres originales de Mirabeau, i., 32 7-334.

vor. $1-23$ 
very rare in the mouth of a man of good breeding. Since that time I have heard repeatedly scandalous remarks that your son has uttered against the parliament and against its head. He even pretends to blame me and all my race for an act of justice that I owe to everybody. I was even obliged, some days before the petition, in order to escape a disagreeable scene, to avoid a very rude jostling that he was preparing to give me, his hat pulled over his face down to his very nose. In spite of my precautions, he soiled my garments. All these little details, that I relate to you only with pain, were preceded by a thousand other incidents that I have hushed up, such as a peasant that he beat, but who returned the compliment, in such a way that he is in bed and has made a judicial complaint; and a crowd of domestics, who have been beaten in turn, protest and leave him, bringing complaint to me. These numerous adventures lead me to fear disagreeable consequences. I should be very unhappy if the humour that I have permitted him to exhale against me in indecent remarks should excite him to the point of causing me to doubt what I ought to do. I fear that he may cause me to forget for an instant that I love and honour his father. I should be very unhappy if youthful ardour should cause him to forget himself and I believe that I ought as a good relative and an old friend present to you complaints dictated by friendship and warn you of the dangers to which is exposed an impetuous head abandoned to itself, that ruins itself with a light heart and that has meanwhile a hand much quicker to strike than to give. ${ }^{1}$

A curious picture of the ancient regime is revealed by the letters of Mirabeau and M. d'Albertas. The letter of Mirabeau is characterised by the pride of birth, the air of haughty superiority toward the nobility of the robe, the independence that is a law unto itself, acts at once and has little need of courts, that even re-

1 Archives nationales, $\mathrm{K}, 164$, No. 2, 2. 


\section{Critical Situation from Extravagance 355}

sists the action of the government when it appears to encroach upon long-established rights. The letter of $M$. d'Albertas betrays an entirely different spirit; it is marked by a want of confidence in himself and in his position; he is led to apologise when he performs the duties of his office, enforcing the law against a barbarous young nobleman, as he paints him. The favouritism that marked the treatment of the noble by the officers of the law, and the willingness of the noble to appeal to the law when he could not attain his ends independently of it, all these traits of the society of the eighteenth century are illustrated by these letters. More than that, they cast a strong light on the influence of family ties upon social life and the bitterness and scandal that made the society of Provence a by-word in France.

Mirabeau had said nothing of his debts in the explanation of the hostility between himself and $M$. d'Albertas. It is quite possible that the first president took malicious satisfaction against a most disagreeable opponent upon whom he could not otherwise lay his hands; it is also highly probable that this act of the judge rendered more bitter the hostility of Mirabeau.

His financial situation grew more critical each day. To meet the demands made upon him, he borrowed from all hands. Among his creditors was a coachman to whom Mirabeau gave a sealed package, containing securities for the sum of six hundred francs that he had borrowed of the man. In 1780 , the bailli wrote to the marquis that, although the time for the payment had expired, the man had not opened his package on account of his respect for the borrower. ${ }^{1}$ When

1 Correspondance générale, ix., 186 . The bailli to the marquis, Aix, January II, I780: "Un cocher de M. de Jouques a un gage cacheté que $M$. le comte lui a remis pour sureté d'une somme de 600 livres qu'il lui a emprunté." 
opened, it was found to contain two small diamonds valued at twenty louis. ${ }^{1}$ The bailli considered the valuation low, as the stones were very pretty. Mirabeau's largest creditors were the Jews, who forced him to take as part of his loan jewelry estimated at a fictitious value, that he could not refuse and that formed a large part of the profits in the transaction. ${ }^{2}$ These debts were, at times, secured by the indorsement of friends who had been moved by sympathy for his distressing situation. 3

If the testimony of Mirabeau may be trusted, he was in despair at the thought of the financial ruin that he saw before him. Immediately after his marriage, he realised the "impossibility of introducing order into this chaos without the aid of his wife's parents." "My wife," he said, "can bear witness to the tears that this first perspective drew from me. I feared to sound the depths of the gulf into which I was about to fall. A false human respect prevented me at the time from avowing the disorder in my affairs and casting myself at the feet of my relatives. I had begun through thoughtlessness, I had continued through necessity, I had finished through feebleness. When I had spoken, it was too late." 4 The refusal of his father to accept the proposition of the Marquis de Marignane to advance

1 Correspondance génerale, ix., 226. The bailli to the marquis, Aix, February 23, r780.

2 Ibid., ix., 352. The count to the bailli, Vincennes, August I8, 1780. Mirabeau here states that of the 40,000 livres due to Daniel Beaucaire he had actually received 700 louis, one hundred of which represented trinkets. In the same letter he stated that he had "touched" about one fourth of what he owed to the Jews.

${ }^{3}$ Guibal (i., 109, note 3) gives a letter written by Madame Duranti-Ladurante to citizen Pin, secretary of the district at Apt. See Appendix IV.

4 Interrogatoire Archives nationales, Y, 499 I. 


\section{Critical Situation from Extravagance 357}

60,000 francs for the payment of his debts cast Mirabeau "into a sort of delirium." "The more I attempted to help myself," he exclaimed, "the greater was the agitation of the whirlpool that was dragging me down. I forced myself to see nothing beyond the present, to stifle my memory, and to turn away my eyes from the future." 1 It was at such a time that a son was born to him.

The child saw the light at Aix, October 8, I773, was baptised the same day at the church of Saint-Esprit, in which his father had been married, and received the name Victor-Honoré-Emmanuel de Riqueti. The godfather was the Marquis de Mirabeau, represented in his absence by the Marquis de Marignane. ${ }^{2}$ Great was the delight at Bignon, where the grandfather then was, over the arrival of an heir. A Te Deum was chanted in the village church, there were illuminations and rejoicings among the peasants. ${ }^{3}$ At Aix, the situation had become desperate. To obtain money to meet the expenses attendant upon the birth of the child, the young mother gave her husband her jewels to place in pawn. Among the papers of Mirabeau in the possession of M. de Montigny is the following significant document, bearing the date October $\mathrm{I}_{4}, \mathrm{I}_{773}$, and signed by the countess: "I declare that I have remitted to my husband a casket containing nine pieces; two earrings, a pair of cornes en croissant, a pin, a Saint-

1 Lettres originales de Mirabeau, i., 3 rg.

2 Guibal (i., I Io) gives the extract from the register of the church of Saint-Esprit.

${ }^{3}$ Loménie, iii., 90 . In a letter of Mme. Julie de Vence to Mirabeau October 13,1773 , she sends congratulations to the countess, "sur le bonheur qu'elle a d'avoir un fils et surtout de l'avoir unique, rar j'ai oui dire qu'elle serait bien heureuse si elle n'en faisait que deux ou trois de cette grossesse."-Minto collection, the property of M. de Montigny. I have used the copy of M. Mouttet. 
Esprit, and thirty gems, to deposit, with whom it may seem good to him, for the purpose of borrowing upon the said effects the sum of 6000 francs, payable anywhere in February, etc." 1 The money was obtained of the Jew, Samuel Cohen, with whom the ornaments were left in pawn. ${ }^{2}$.Shortly after the birth of his son, Mirabeau was obliged to leave the mother and child, "without doubt to escape the clamours of his creditors." $\mathrm{He}$ retired to the chateau; Madame de Mirabeau remained at Aix. ${ }^{3}$

As soon as I had a son [wrote Mirabeau], I felt that it was no longer a question of averting the tempest, but of affronting it, instead of permitting it to increase. I withdrew to Mirabeau, resolved not to attempt the least ruinous effort to postpone an inevitable crash. I still kept the workmen; you know, my father, whether I could discharge them. I wrote to you, to your agents, to your friends. I protested against the inferences that might be drawn from these burdensome delays, that I could not prevent. Three entire months I was allowed to persevere in my follies in the midst of my misery:" Workmen from all parts of the world cannot be sent away with promises to pay and I had no kind of pecuniary aid; as soon as I was offered money, all were sent away and an inspection of the apartment will prove that it is very far from being finished.s

M. de Marignane blamed him for continuing the work at the chateau and the countess wrote to him from Aix begging him to suspend it: "You ought to do it,"

1 Mouttet, Mirabeau en Provence (Chap. iv., 8), gives the document. The original is in the collection of M. de Montigny: See, also, Interrogatoire, Archives nationales, $\mathrm{Y}, 499 \mathrm{r}$.

${ }^{2}$ Ibid.

3 Lettres originales de Mirabeau, i., 322 ; Guibal, i., 110.

- Ibid.

5 Interrogatoire, Archives nationales, Y, 4991. 


\section{Critical Situation from Extravagance 359}

she added, "for my peace of mind and for the life of your child, who will be our saviour with your parents, and who will infallibly perish if I continue to experience such trying vexations. Pardon me, my dear, for entertaining you with such sad things; but to whom shall I talk of my troubles, if not to the sole man in whom I have confidence and the only one that shares them?" Mirabeau's friend the notary Raspaud "made her tremble on account of all the drafts that had been indorsed. The indorsers were threatened with the seizure of their property and with imprisonment. Those beggarly Jews have become unmanageable." 1 It would appear that Mirabeau, fearful at finding himself at the mercy of his creditors, thought of appealing to his father to save him by soliciting a lettre de cachet that would confine him in the Chateau d'If or some other state prison. That, at least, is the statement made to the Marquis de Mirabeau by the Marquis de Marignane in a letter written from Aix, November 28, I773:

I am much pleased, Monsieur le Marquis, that you feel the propriety and even the necessity of taking charge of your grandchildren. [After some playful allusions to "the only one that exists" and to "those that do not yet exist" he proceeded to describe the critical situation of his sonin-law.] Since the last letter that I had the honour of writing to you, very few days have passed that have not given me knowledge of some new debt or of some jewel sold or pawned. Of the diamonds that you sent my daughter at her marriage, of the few that I gave her, there remain only two bracelets, one of which came from you and another that your son had made for her here. The rest have disappeared; I do not know whether they have been pawned or

1 Guibal, i., I Ix. 
absolutely sold. The toilette is in pawn; the six thousand francs that I owe them is ceded for three years; several drafts that have fallen due have already been protested. The position of your son frightens even him.

I have seen a letter that he wrote to $M$. Raspaud in which he remarks to him that, neither you nor I being willing to make any arrangements with his creditors, rather than find himself at their mercy, he is quite ready to pray you to solicit a letire de cachet to have him shut up in the Chateau d'If or in any other chateau that it may please you to choose. You will readily understand that, being in this disposition, he regards as a very great favour the order of the king that you propose to have given him to reside at the chateau de Mirabeau. If it is still your intention, I warn you that there is no time to lose. I believe that to the I 200 francs that you count on leaving him it will be necessary to add 1800 for his wife, who at the moment that she is nursing has need of two women, one of whom is needed to take care of the child. Besides these two women, she needs a lackey and a cook. It does not appear to me that they can be allowed less than three thousand francs. The surplus, as you think, ought to be put aside to pay the creditors and we will request $M$. Raspaud to be kind enough to take charge of this sort of direction.

I hope that he will make a good arrangement for us in the matter of these debts, three fourths of which are usurious, this gentleman doing business only with Jews when he wanted to find money. M. Raspaud will also be the treasurer of the three thousand francs that will be left to them. [Raspaud was to receive express instructions, as the marquis had "very judiciously observed," to use the money only for necessary expenses, such as those of the butcher and baker.] When order has been introduced into their affairs, we can occupy ourselves more in detail with the arrangements with the creditors. M. Raspaud, from whom I draw a part of the details that I send you-several creditors having addressed themselves to him,- - did not 


\section{Critical Situation from Extravagance 36r}

dare to write to you to inform you for fear of compromising himself with your son, which I am glad that he has not done, he alone being able to draw from him much information that will become necessary to us for the general arrangement to be made with the creditors. ${ }^{1}$

In November, I773, Mirabeau was in desperate financial straits. He might have been relieved by the payment of his debts, but both the Marquis de Marignane and his father had declined to make any settlement with his creditors. It was probably impossible at this time for his father to do so, or, at least, the action of the Marquise de Mirabeau, early in December, so occupied his attention that he was willing to free himself temporarily from the vexation caused by the extravagant conduct of his son. The life of Mirabeau was again influenced in a baleful manner by his father's speculative marriage. The marquis had not executed the will of Madame de Vassan, that gave to her daughter the income of the estate of Brie (800o livres), nor had he increased her yearly allowance to 10,000 livres as he had agreed to do at the death of her mother. On the contrary, he continued to pay her five hundred livres each month, trusting that she would adhere to the agreement of 1766 and not leave Limousin without his permission. If the marquise remained quiet for three years, it was because she could find no lawyer to undertake her case. The situation changed in 1773 , when Madame de Cabris, accompanied by her insane husband, hastened to Limousin and, enraged over a fancied neglect-her elder sister had received a larger dowry than she,- - placed 20,000 livres at the disposal of her mother that a lawsuit might be begun against the

1 Archives nationales, K, 164, No. 2, 2. 
marquis. As a return for this favour, the marquise promised to bequeath 60,000 livres to her daughter.

Early in December, I773, the marquis was surprised to learn that his wife had arrived in Paris accompanied by a business agent from Limousin and an abbé, and that she was well supplied with money. He at once complained to the Duc de la Vrillière that the compromise of 1766 had been violated, but the minister replied that the compromise did not prohibit his wife from having access to the courts and that he could not prevent her from coming to Paris for that purpose. Not knowing what course the marquise might follow, fearing that she might present herself at his door asking admittance, and on being refused demand a legal separation and division of the property, he left Paris, going to the home of a friend in the country at Coulomb, and left the bailli as the lessee of his house in the rue de Vaugirard. The marquise resided provisionally with some of her relatives and began negotiations with the bailli, who, it will be remembered, was not filled with affection for his sister-in-law. He rejected all the propositions that the negotiators made to him. When it was suggested that she might come to ask a lodging of him, he answered that he did not consider it his duty to lodge anyone. Intimidated by the attitude of the bailli, induced by the minister Bertin not to begin a suit for divorce, the marquise contented herself with beginning action against her husband for the income of 8000 livres from the estate of Brie and in addition for the payment of an annuity of 4000 livres. Then through the mediation of Bertin and of the Comtesse de Beruelle, a relative of the marquise, a second compromise was reached; the marquise agreed to return to Limousin and to continue to remain there, 


\section{Critical Situation from Extravagance 363}

enjoying the revenue of the estate of Brie, and her husband promised to pay her in installments the sum of Io,000 livres and furnish the chateau of Brie with furniture in good condition. ${ }^{1}$

The marquis was, without doubt, pleased to escape so easily. According to his own statements-that in a case of this kind would naturally lack scientific accuracy - "after having raised a numerous family, having received from his wife during thirteen years only 4000 livres annually, the total of her revenues, after twentyseven years of marriage, amounted to 31,300 livres, and that, after deducting expenses, foundations, debts, legacies of Madame de Vassan, annual repairs, the part due from his wife for dowries and the establishment of the children, the net revenue personally pertaining to his wife reduced itself to 1o,500 livres." Had the marquis been obliged to make a settlement with his wife, dividing the property, it would have meant financial ruin. ${ }^{2}$

It is easy to understand why at this time, the marquis could not have been in a very kindly frame of mind toward his extravagant son in Provence. Something must be done, however, and as he would not, 3 or could

1 Lomenie (ii., 479-486) contains a detailed treatment of the relations between the marquis and the marquise in 1773 .

2 Ibid.

3 In a letter to the bailli, written from Bignon, July 8, i 780 (Correspondance générale, ix., $3^{\mathrm{r}} 3$ ), the marquis makes a statement of his expenses at Bignon, including clothes, linen, books, and charity. They were 21,307 livres in $1777,18,238.93$ in 1778 , $17,740.60$ for $\mathrm{r} 779$. Had his son kept his expenses within the most reasonable limits, he would not have had 7000 livres to last him through the first year of his married life, after paying for the marriage contract and the expenses of the wedding, none of which things the marquis provided for. At the very time that the marquis was preparing to exile his son to save him from his creditors, he was 
not, pay the debts until a careful examination had been made of them-most of them being usurious-and as his son must not be allowed to fall into the hands of his creditors-the family name would be disgraced-he decided to appeal to the government and to gain time by placing Mirabeau "under the hand of the king," by means of a lettre de cachet.

placing his chateau at Hyères at the disposition of Miss Pitt, sister of Lord Chatham and a friend of Madame de Rochefort. On December 22, I773, Miss Pitt wrote to Mme. de Rochefort from "the paradise of M. de Mirabeau." She describes the house as "a little palace."-Louis de Lomónie, La Comtesse de Rochefort et ses amis, 221, 222. 


\section{CHAPTER XIV}

\section{LETTRES DE CACHET AND INTERDICTION}

$7 \mathrm{HE}$ persecutions of his wife, for it was in this light that the marquis considered her appeal to the courts for relief, were not the chief cause of the exile of his son. They undoubtedly, however, determined the marquis to take a step that he had been meditating for some time. According to his own statement, he had purposely allowed "the pear to become ripe that it might fall into the hand without opposition." $\mathrm{He}$ had always been possessed of a healthy fear of public opinion and of the support that his enemies in high places might give to his son, and he was ever on the watch for new "witnesses" that he might make use of them when it became necessary to resort to severe measures.

You can easily understand [he wrote to the bailli after the lettre de cachet had been issued] that, being entirely new in this kind of an affair, realising the feebleness and the inutility of those people down there [in Provence, meaning especially M. de Marignane], realising, also, how important it is, in the first place, for my reputation, that I let the waste go on down there during the time of the shocking misconduct of this fool, because I felt that it was necessary for the pear to become ripe that it might fall into the hand without opposition and with the approval of all, and that we should compromise ourselves by vain attempts if we tried 
it before; second, for my duty and the success of the affair, that I march at present with a firm and solid step, I have not slept much over this thing since the curtain went up. ${ }^{1}$

Embittered by the course of the marquise, the Marquis de Mirabeau would gladly, at this time, have placed his son behind prison bars had he not been restrained by considerations entirely foreign to the well-being of the young man. "It would avail more for our momentary repose," he wrote in the letter that announced to his brother his intention to ask the government for a lettre de cachet, "to lock up this bad son of a bad mother. But, from what I have seen of the character of his wife, we should destroy the whole race at one stroke." 2 It was a serious matter and, being forewarned, he had meditated much upon it. "The destruction of the race," to a man who had devoted his whole life, who had sacrificed the happiness of his wife and children, to the fetich of "posteromanie," as the bailli called it, and to the formation of a great landed estate, would be a frightful catastrophe, a lamentable end to a lifetime of effort. He had hoped that Boniface might prove to be the salvation of the family, but, in spite of his fondness for the boy, he was not blind to the fact that he promised to be as undisciplined as his brother. He treated him, however, with a reasonableness that is seldom encountered in his attitude toward the elder brother. "He will run through all the excesses of debauchery," he wrote to the bailli. "If he gets into debt, you will have him shut up until they are paid; we will know nothing about

1 Correspondance generale, vii., 58. The marquis to the bailli, Coulomb, December 22, 1773 .

2 Ibid., vii., 52. The marquis to the bailli, Coulomb, December 13,1773 . 


\section{Lettres de Cachet and Interdiction 367}

the rest of it. He will return an honest man [from Malta-he was a chevalier de Malte], I hope, after the transport is past and will be so much the better support for his family as such than otherwise. It is necessary for us to perpetuate the line through those people down there. The blood of Vassan will purify itself by that of Marignane, which is mild." 1 Mirabeau was exiled rather than imprisoned because his father feared that the extreme course might work havoc with his dream of perpetuating the race of the Riqueti.

On the same day when he thus expressed himself to the bailli, the $3^{\text {th }}$ of December, I773, he wrote to the Duc de la Vrillière asking for a lettre de cachet. "It is my misfortune," he began, "to be forced to importune you often for a list of fools, of whom fate has willed that I should be in some sense the guarantee. My son, whom I married last year in Provence, because they wanted him, has ruined himself there by a mass of usurious debts which prove him to be the worthy son of his mother." Parenthetically, it might be noted here that the marquis never draws this inference from the debts of his younger son. This fact might be cited in support of the hypothesis that the harsh treatment of Mirabeau by his father was largely due to the personal aversion that the marquis felt for him.

He deserves only to be abandoned to his fate [went on the marquis], but as he has a worthy wife and already a child, it is less for him than for his family that I take the liberty of asking of you a letter of exile, which gives time to his relatives to make arrangements with his creditors and to prevent him from ruining himself, or, more correctly, ruining his family entirely. I know, Monsieur le duc, that it is purely a favour that I ask of you, but I hope that you will

'Correspondance générale, vii., 58. 
take pity on a man doubly unfortunate and that you will deign to come to the aid of a notable family that has always served its masters well and has not deserved to be scourged by all kinds of extravagance. A letter of $M$. de Marignane, the father-in-law of this fool, that will be placed under your eyes, will show you that this is the wish of two families. ${ }^{1}$

This letter offers an excellent illustration of the régime that existed in France before $r 789$. It was of a member of the Maupeou ministry that the marquis asked his favour, a ministry that had but recently destroyed the parliaments, the only bulwark that existed against arbitrary government. While the King disposed arbitrarily of the persons and property of his subjects, the marquis disposed as arbitrarily, through the assistance of the minister, of his married son, protecting the son from the consequences of his acts, saving himself from the importunities of the creditors. It was a state of things against which all those who suffered protested, but many of them, like the Marquis de Mirabeau, gladly availed themselves, in their private affairs, of those very instruments of arbitrary government that they criticised in their public utterances. In an age in revolt against arbitrary methods of government, Mirabeau was submitted to the tyranny of paternal government, until, to a nature intolerant of control, the hatred of despotism became a passion.

The marquis did not name, in his letter to Duc de la Vrillière, the place to which he was desirous that his son should be exiled. He had left this matter to his brother, sending him a letter to the minister authorising him to act. "I hesitated very much in regard to Mirabeau,"

1 Archives nationales, $\mathrm{K}, 164$, No. 2, 4 . 
he wrote on December I 3 th, "for you have seen by those letters the disorder that he has created there and you have not seen the half. I have, however, considered (I) that elsewhere he would again cause trouble and commit faults; (2) that Marignane, who was at first opposed to it, now requests it himself; (3) that he will suffer less from it. However, if you think otherwise, I leave you entirely master of the place." The affair was urgent. "I believe that there is not a single minute to lose; but our friends of the Luxembourg [Mme. de Rochefort and the Duc de Nivernois, or, perhaps, Mme. de Maurepas] will do this for you as soon as possible, if you tell them the consequences. . . You may make use of the letter of Marignane to show that the two families agree about this thing." 1

The bailli acted with all possible despatch. The I6th of December, I 773, the letter of exile had been addressed to the intendant of Provence, Senac de Meilhan. "You learned yesterday," the bailli wrote on the 2Ist of December to his brother, "that your Provençal has been fixed at Mirabeau. God grant that we have been in time to prevent him from being arrested for debt! We lost no time, for it left for Provence on Saturday" (December 18 th). ${ }^{2}$ The marquis was not satisfied to leave the execution of the order to the government. It will be remembered that when Mirabeau was sent to the Ile de Rhé, his father kept him under constant surveillance. He followed the same course at this time. "I do not know the name of our new intendant," he wrote to the bailli on the $22 \mathrm{~d}$ of December, "and there

1 Correspondance générale, vii., 52. The marquis to the bailli, Coulomb, December I 3, I 773 .

2 Ibid., vi., 6r. The bailli to the marquis, Paris, December $2 \mathrm{r}$, I773.

voL. $I \rightarrow 4$ 
is no royal almanac here, otherwise I would have written to him recommending strict execution and requesting him to be kind enough to charge some one in the canton, in whom he had confidence, to give him an account of the strictness with which [the order] was obeyed. If you judge it proper, you may write this letter in your name and in mine." 1

The letter of exile was but a temporary expedient; its purpose was to save Mirabeau from arrest while a settlement was being made with his creditors. It was quite natural, then, that, at the same time that he provided for the safety of his son, the marquis should have under advisement a plan for the settlement of his debts. The same letter that authorised the bailli to write to the intendant contains proof that the question of the settlement of the debts had been considered before the lettre de cachet had been asked for.

My host [he wrote from Coulomb] is from the region governed by written law. He is full of it, both as a matter of taste and of habit. He is very cautious and is, furthermore, well versed in the usages of this region here. He has seen the grand chamber of Paris annul the debts of the son of a Bordeaux family to the amount of 300,000 livres on the ground that he was not emancipated. Now this grand chamber has no idea of the paternal authority in our part of the country. My son was not emancipated. But here a difficulty arises. You will find it deduced at the end of this letter in the form of a consultation. If Desjobert [the lawyer of the marquis in Paris] and those whom you see fit to consult, adopt the idea, I want a model from him, etc. You will send me this model, and on your part, as principal relative, you will sign a similar procuration and

1 Correspondance générale, vii., 58. The marquis to the bailli, Coulomb, December 22, 7773 . 
send it to Raspaud [the lawyer at Aix], whom I am about to notify of that and also that I will send him my own. However, I charge you to consult down there our best advocates on the matter.

The letter was accompanied by the consultation. The question submitted was, "What ought to be the course taken by a father to wipe out a mass of usurious debts, the father being of the region of written law, who has married his son under this law and has not emancipated him?" There were two courses open. "The first was to attack these debts as null. A son not emancipated, living in the region of written law, could neither procure food nor make contracts validly. There are a thousand examples of it under this law." The Bordeaux case, given by the marquis, was then cited.

One difficulty is, however, to be feared in this case; it is that the father is domiciled at Paris; that in the marriage contract of his son he did not take the precaution to choose a domicile in Provence; that his son was born, furthermore, under the common law of Paris, and that it is to be feared that the creditors will pretend that this constitutes an exception and will say that as to his property, the son is not free to contract, in so far as they follow the law, but that as to his person, it is not subject to the strict formality of emancipation. [If the council should take this view of the matter] it is the intention of the relatives to have this fool declared a minor [interdicted] on the ground of proven dissipation, and at the request of his relatives, to have appointed an honorary guardian to his rights and actions for the purpose of liquidating his debts, discovering the nature of them, exercising his rights, caring for his maintenance, and doing, finally, whatever may be required for the interest of the third party and that of his family. The question is 
what ought to be the form of this procedure and the model of the procuration that ought to be sent by the relatives ad hoc, always assuming that the council rejects the first course mentioned above, the shortest, the most summary, and the most in accord with the usages of the country. 1

The $2 \mathrm{~d}$ of January, $\mathrm{x} 774$, Desjobert had not given his opinion upon the consultation ${ }^{2}$ and the gap in the evidence at this point makes it impossible to trace the steps taken in this matter previous to March, $\mathrm{x} 774$, when it again rises above the horizon.

The life of the marquis at this time was truly filled with vexation and sorrow. His thanks to the Duc de la Vrillière for having "heard his prayer and placed him in a position to arrest the youthful madness of a fool" were mingled with the hope that he "would not forget his other wishes and would aid him in saving his honour, compromised more seriously still and much nearer home." 3 The marquis here refers to the acts of his wife. Through the bailli, he was endeavouring to have his wife sent back to Limousin. "The request to have the lady sent back to her domicile," wrote the bailli, January 2, I774, "has always been the first of my demands, but is precisely what they do not wish and what they say they are not able to accomplish." 4

Meanwhile, the lettre de cachet $^{5}$ was on its way

1 Correspondance générale, vii., 58 . The marquis to the bailli, Coulomb, December 22, 1773 .

2 Ibid., vii., 70. The bailli to the marquis, Paris, January 2, I774.

${ }^{3}$ Archives nationales, $K, x_{4}$, No. 2, 5. The marquis to the Duc de la Vrillière, Coulomb, December 22, 1773.

- Correspondance générale, vii., 7o. The bailli to the marquis, Paris, January 2, 1774.

s "Sa Majesté mande et ordonne, au sieur comte de Mirabeau, qu'aussitôt après la notification du présent ordre, il ait à se rendre 
to Provence. It was received by Senac de Meilhan at Aix, probably about the $23 \mathrm{~d}$ of December. ${ }^{1} \mathrm{He}$ wrote at once to the advocate Desorgues at Aix, enclosing a copy of the order and a letter for the Marquis de Marignane. ${ }^{2}$

I personally remitted the letter to him yesterday [wrote Desorgues to Senac de Meilhan], as you desired. He appreciated very much this attention and gave me to understand that these orders were the outcome of a family arrangement. M. le comte de Mirabeau having been for some days at Mirabeau, I requested the Marquis de Marignane to designate the person that would be the most agreeable to him for serving notice of the orders, and he having indicated to me M. Huart, whose discretion was known to him, I have just charged him with them. He will depart to-morrow early. I recommended to him to acquit himself of this commission with the greatest circumspection, and entrusted to him at the same time a letter to M. le comte de Mirabeau in which

au château de Mirabeau et à y demeurer jusqu' à nouvel ordre de sa part, à peine de désobéissance.

"Fait à Versailles, le seize décembre I 773.

"Signé: Lours.

“Phélipeaux.

“ J'ai recu les ordres ci-dessus mentionés. A Manosque, ce 28 decembre 1773. Mirabeau fils."

The original, with Mirabeau's signature, is in the Archives des Bouches-du-Rhone, Intendance de Provence (C.I.), Carton No. 393. The documents relating to Mirabeau contained in this carton have been published in the Revue rétrospective (July to December, I889), Paris, 1889, 24I-25I.

1 It took about a week for a messenger to travel from Paris to Aix. We have the receipt of Senac de Meilhan (Archives nationales, $K$, I62, No. 2, 7), dated Aix, December 29, I773, addressed to La Vrillière, in which he states that the order has been served and that Mirabeau has betaken himself to the chateau. On the 24th of December, Desorgues, at Aix, had been notified of the arrival of the order.

2 Revue rétrospective ( $188 \mathrm{~g}$ ), letter of Marignane (p. $24 \mathrm{r}$ ), of Desorgues (p. 242). 
I remarked that you had sent to me from Marseilles, where you are, the orders of the king; that, believing him in this city, you had charged me personally to present them to him with all the regard that is due to him; that I had had the honour to inform the Marquis de Marignane of all that has passed and that he had himself indicated M. Huart to present to him the orders of the king.

The messenger did not find Mirabeau at the chateau. $\mathrm{He}$ had gone to Manosque. It was there that the order was served upon him and he acknowledged its receipt, writing at the bottom of the lettre de cachet: "I have received the orders above mentioned. At Manosque, the 28th of December, I 773." 1 On the 29th of December, Senac de Meilhan wrote to the Duc de la Vrillière that the order of the 16 th concerning the Comte de Mirabeau had been received, that the notice had been served, and that he had in consequence betaken himself to the Chateau de Mirabeau. ${ }^{2}$

The bailli had evidently written to the intendant the letter suggested by his brother, containing the request that a strict surveillance should be exercised over the exile. That, at least, is the inference to be drawn from the following letter of Mirabeau to Senac de Meilhan, written at Mirabeau, the I 5 th of January, I 774:

I am not a person of sufficient importance, Monsieur, to be the object of the king's attentions and to cause you the trouble of giving an account of my conduct. I attribute, then, the letter that you have seen fit to write to me to your complacency for my family, that has not doubted your influence upon my mind and that has requested you to inspire me with a bit of fear, a thing to which I am not very susceptible. Whatever may be the motive of your

- Revue rétrospective (1889), 244.

2 Archives nationales, K, r64, No. $2,7$. 
warning, I commence, then, Monsieur, by assuring you of my appreciation. I am going to reply to you, thereupon, with the most perfect frankness.

I avow to you, at the outset, that I do not understand and never can understand how a lettre de cachet that enjoins me to retire to the chateau de Mirabeau, and to dwell there until I have received other orders, can place me in a position to run any risk, in leaving the chateau. If the intentions of the king were to keep me shut up there, he would, without doubt, have sent me rather to some citadel.

Demeurer is equivalent to domicilie, or, in its most rigorous acceptation, ne pas découcher. I shall believe myself obliged to do only that until new orders of the king shall have changed for me the French language.

Furthermore, Monsieur, I do not believe that in my position I could live well or decently anywhere but at home. Believe, then, if you please, and be persuaded, independent of all species of delation, that the hunt and the promenade will be the sole distractions that will tear me from the chateau de Mirabeau.

I assure you, likewise, that I will certainly contract no liabilities, even if the patient lenders should be tempted to come to me to offer their services.

As to the superfluous expenses, I am delighted to find an opportunity to say to you that, in spite of my frequent and successive demands, I have not been given the power to discharge the men who are working for me by the day and who are eating me up and that it is neither just nor possible to dismiss them without pay. Permit me to deposit, in your hands, an authentic and formal protestation against all that may be inferred from their sojourn here, this sojourn being as contrary to my desires as it is disproportionate to my means.

There, Monsieur, is my very sincere profession of faith, and, generally speaking, I may only say that it is not to my hypocrisy that I owe my enemies. I burn with the desire to arrange my affairs, to live in solitude with the 
moderate annuity that will be assigned to me; but it is necessary that my accounts should be balanced and that the petty debts, the payment of which it is impossible to postpone, may be met from the sum necessary for my own support and the maintenance of Madame de Mirabeau.

I prize too highly your esteem, Monsieur, not to receive your advice with deference and gratitude, and I have too good an opinion of the one that gives it, to fear that you would invoke the authorities against me without having fathomed the verity of the pretended infractions of the orders of the king with which I may be accused. It would not, assuredly, be the first time that I would be the object of Provençal charity. Have the goodness to ask for an account of my conduct, in everything that you may believe interests the obedience that I owe to the orders of the king, and I leave to you the report you ought to make, persuaded as I am of your impartial equity. 1

Mirabeau "was exiled and he gloried in it," 2 but he refused to be treated as a prisoner and placed under surveillance. If he were not actually within prison walls, he certainly was reduced to prison fare. In an undated letter, written at Mirabeau, probably in March or April, I774, addressed to his cousin, M. de Limaye, he described his condition in these words: "I am in the most dolorous situation here. The daily ration of my wife, myself, and my servants has been fixed at seven livres of meat, six of brown bread, and three of white bread. I do not know whether my heart is more lacerated or irritated by all these humiliations." 3 The Marquis de Marignane

believed that the father-in-law of his daughter had cal-

1 Revue rétrospective, 244.

2 Lettres originales de Mirabeau, i., 322.

${ }^{3}$ Mirabeau to Limaye, written at Mirabeau, April 9 (?), 1774. The original is in the collection of M. de Montigny at Aix. 
culated a little too rigorously. . . . He did not doubt that the marquis would yield to the observations of the notary Raspaud and thought that he could authorise his children to attribute to themselves the little supplement judged necessary. ... U Unfortunately he envenomed this concession, of which he was not master, by the commentary with which he accompanied it: "Your wife," he said to his son-in-law, "wishes to share your lot. She ought to be the first to desire that your expenses be reduced to the lowest point possible that you may take from your creditors only that which is strictly necessary for her and for you." 1

Mirabeau's acts were not entirely in keeping with his words. He was "irritated by all these humiliations," he was desirous of "living within his modest income," but his desires outran his resources and he resorted to expedients to satisfy his wants that were far from creditable. He sent a horse to Marseilles to be sold, that he had bought eight months before and for which he had not yet paid, and "he did not appear to comprehend the impatience of this honest man (M. Granet) to receive the price of the animal. M. Granet was, moreover, his creditor for a sum four times as great. An enthusiastic hunter as well as a daring rider, the young count had just purchased a considerable number of guns, but did not appear to be in a hurry to restore the one that M. de Marignane claimed from him." 2

All of this was very distressing, no doubt, for Mirabeau. We learn from his letters that "he suffered in soul and in body" and complained to his notary and friend Raspaud of his continual annoyances, that "deprived him of the faculty of writing and almost of thinking." 3 Burdened himself, he could no longer

1 Guibal, i., II4.

2 Ibid., i., II3.

3 Ibid., i., I I 5, referring to Mirabeau's letter of February I9, I 774 . 
sustain, console, and entertain his young wife, who found only more dangerous charms in the society of the young grey musketeer, Chevalier Laurent-Marie de Gassaud. He came of a good family of Manosque. The bailli was a close friend of his uncle and had interested himself in young Gassaud. ${ }^{1}$ When, in January, 1770 , the young man went to Paris, he was warmly recommended to the marquis by his brother, was kindly received, invited to receptions and to the economic dinners." "The little or the big Gassaud, as the bailli called him, was nineteen years old and five feet eight inches in height; he appeared very steady, and the marquis, who often deceived himself in his estimates of men, judged that he was the kind of stuff that fathers of families are made of. During the winter and the beginning of the spring of $\mathrm{I} 774$, he was at Manosque. Personally attached to Mirabeau, he became an assiduous visitor at the chateau where the young count was relegated. In the intercourse that she had with this friend of her husband, the countess forgot her ennui, her chagrin." 3 Fearing that his wife was treading on dangerous ground, Mirabeau warned her of the risks she was taking. He repeated his criticism of her conduct and at last she answered him angrily; he lost his temper. At first, he thought of having an understanding with Gassaud, but was checked by the fear of injuring him in the minds of his parents. Before leaving for Paris in the spring of that year, Gassaud had succeeded in fully reassuring Mirabeau, who de-

1 Mouttet, Mirabeau en Provence, 63-73; Guibal, i., 115, I16: Correspondance générale, v., 480, 48 I, 484, 498.

2 Ibid., vi., 268, 485 , quoted by Guibal, i., 116 .

'Guibal, i., I 6 . 
clared he "would have believed it a crime to have suspected friendship of treason." 1

Meanwhile, the agents of the marquis at Mirabeau had represented to him that the depredations of his son were rapidly ruining the estate; he was cutting down the trees, selling the furniture, and turning everything that he could into money. The marquis accepted these reports as true. 2 "People have always been sure of finding credence with you by speaking ill of me," 3 observed his son. This complaint of Mirabeau is far from being without foundation. In the interrogatory in May of this year, Mirabeau replied to these charges. ${ }^{4}$ When asked if he had not used the money derived from the trees cut at Mirabeau, he replied:

I had some pines cut down, the number of which I do not know, but I can prove conclusively that those cut did not amount to fifty écus, and I used more than five thousand francs' worth of wood in the chateau. I offer to prove further that this extensive tree cutting that has been imputed to me was done by the orders of the Cure de Neuville. There may be included in the wood cut, that which was employed in a limekiln, that I sold for fifty écus. This limekiln having been destined for repairs that I was not able to finish, I preferred to sell it rather than to let it perish in the rain.

He was also interrogated concerning the chamber. His explanations concerning that point have already been utilised in describing the attempted transformation

- Letter of Mirabeau to Gassaud, Manosque, not dated, but written at Manosque, probably May 28, 1774. A copy is found in Mouttet, Mirabeau en Provence, chap. v.

2 Archives nationales, K, I64, No. 2, 9.

3 Lettres originales de Mirabeau, i., 310.

- Archives nationales, I, $499 \mathrm{I}$. 
of the chateau. His account agrees with the statements of the bailli. As to selling the furniture, he called his father to witness that in the inventory drawn up a month before, at the chateau de Mirabeau, the agents had found more than fifty thousand francs' worth of new furniture. He did not deny (and he had no reason to deny) that in having a bed of red damask made over, trimmed with a gold galoon more than a hundred years old, that no longer showed anything but silk and could not be used upon a new piece of furniture, he had this galoon burned, as it was good only for that and the greater part was not genuine. $\mathrm{He}$ obtained from it twenty-two louis, that seemed more than replaced. He was so little disturbed at this use (of the galoon), was so far from fearing to displease his father, that he did not make any note of the goldsmith who burned the galoon, although it would be easy to find him again. ${ }^{1}$

This is Mirabeau's answer to the charges that were made against him. They are corroborated by the statements of the bailli in his correspondence with his brother. The bailli asserted that he had convinced himself that Mirabeau had been slandered in regard to the cutting of the trees and that it was the very persons that had accused him who had pillaged the chateau. He had discovered fine linen in the cottages of the peasants in the village. ${ }^{2}$ At another time, he assured his brother "that the facts, on account of which Mirabeau was exiled to Manosque, were partly false. He has neither sold nor cut your wood, nor sold your furniture." 3 The marquis himself, if we may trust a quotation of M. de Montigny, acknowledged

- Archives nationales, Y, $499 \mathrm{r}$.

2 Correspondance générale, $x ., 428$. The bailli to the marquis, Mirabeau, December, 1782.

Ibid., x., 525. The bailli to the marquis, Aix, March $7, \mathrm{I}_{783}$. 


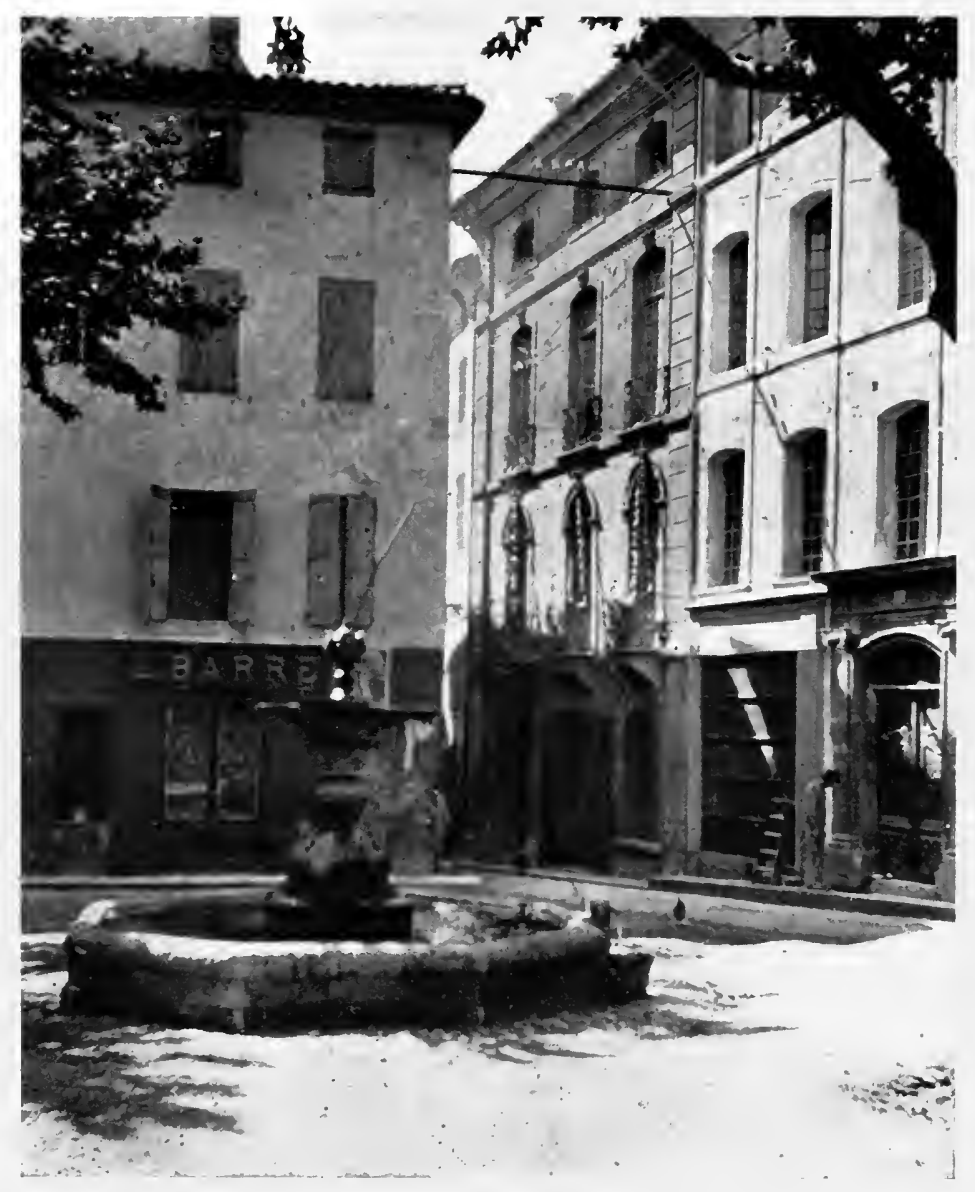

The Residence of Mirabeau at Manosque

First house on the right

From a photograph by H. D. Fling 
. 


\section{Lettres de Cachet and Interdiction $38 \mathrm{I}$}

that "this fool turned everything topsy-turvy, but he put back more than he took away." 1 It is not easy to get at the truth of the matter. It is probable that the charges were "partly false," but there was enough truth in them to cause the marquis to desire to change the place of residence of his son.

On the I8th of March, I774, he accordingly appealed to the Duc de la Vrillière in the following language:

You had the goodness a few months ago to obtain for me an order of the king that exiled my son to the chateau de Mirabeau. Paternal consideration for his young wife, who up to the present time has remained constantly attached to the lot of this madman, decided me not to ask for the prison that he has deserved only too well. Now he is throwing everything into disorder on my estate, selling the wood, the furniture, etc., interfering with my agents and cannot be permitted to remain there. A continuation of commiseration for his respectable wife restrains me and should restrain me. Do me the favour, Monsieur le Duc, to accord me a change of exile for him to the city of Manosque, adding to it, the prohibition not to leave the city and its territory. M. le Marquis de Rochechaud, who should have the honour to see you to-morrow, and who has seen the letters and the proofs of his last follies, has promised me to speak to you about them. I hope that you will be good enough to accord me this new favour promptly. ${ }^{2}$

The order was issued the twenty-fifth of the same month and sent to Senac de Meilhan, accompanied by a letter from the minister. ${ }^{3}$ In the lettre de cachet

1 Montigny, Mémoires de Mirabeau (ii., 18, note 2). The marquis to the bailli, August 14, 1779 .

2 Archives nationales, $\mathrm{K}, 164$, No. $2,9$.

3 The lettre de cachet is in the Archives nationales, $\mathrm{K}, \mathrm{r} 64, \mathrm{No}, 2$, Io; the letter to Senac de Meilhan is in the collection of documents in the Revue rétrospective ( 1889 ), 246. 
Mirabeau was ordered to withdraw from the chateau and to betake himself at once to Manosque, to remain there until he had received a new order. He was also enjoined to send to the Duc de la Vrillière a certificate of the judge or of the principal officials of the city of Manosque as proof of his arrival. He was not forbidden to leave the city. On the receipt of the order, the intendant forwarded it to the Marquis de Marignane at Aix requesting him to present it to the count at the chateau. Instead of doing this in person, Marignane passed on the disagreeable task to $M$. Maurin, the sub-delegate at Manosque. ${ }^{1}$

You will find enclosed, Monsieur [he wrote], the orders of the king that have been addressed to me, in which he has ordered M. le Comte de Mirabeau to withdraw from the chateau de Mirabeau, to which he retired in virtue of an order of the king of December I6th last, and to betake himself to Manosque, at once after receiving notice of the orders of his majesty. I pray you, Monsieur, to be kind enough to charge yourself with this notification. I have no need to recommend you to show to M. de Mirabeau all the consideration that is due, but you will have a care to ask of him his submission to these orders and you will explain to M. and Madame de Mirabeau that they are permitted to take with them from the chateau de Mirabeau their clothes and nothing else. When he reaches Manosque, you will obtain a certificate of the judge or of the principal

1 Revue rétrospective ( 1889 ), 247,248 . The letter, addressed to $\mathrm{M}$. Maurin, that I have attributed to M. de Marignane, is anonymous. In the margin, is the note: "J'ai Écrit de ma main au sieur Maurin et envoye les ordres le 3 avril." In the same collection, is the following note signed by Marignane: "J'ai reçu, de monsieur l'intendant, l'ordre du roi pour signifier à monsieur le comte de Mirabeau. A Aix, 3 avril, 1774.-MARIGNANE."

This receipt proves that Marignane must have been the writer of the letter. 


\section{Lettres de Cachet and Interdiction}

officials of this city, as proof of his arrival, and you will send me this certificate.

The notice was served by M. Maurin on April gth; Mirabeau made written acknowledgment of the notification and promised to obey the orders at once. A certificate, signed and sealed by the mayor and officials of Manosque, stating that Mirabeau and his family arrived in the city on the tenth of the month is proof that he kept his promise and left the chateau "at once." 1 In addition to his clothes, however, he carried with him "some books that the countess, in spite of the formal prohibition, had taken for him from the library of the chateau."2

Manosque, a city with less than six thousand inhabitants, is built upon an eminence overlooking the fertile valley of the Durance. It was formerly surrounded by walls and some traces of them, including two of the city gates, still remain. Apart from the old and picturesque city square, commanding a view of the valley and the hills beyond, there is little that is attractive in the place with its narrow and badly paved streets. It formed a striking contrast to the provincial splendour of Aix and to the rural beauty of the chateau de Mirabeau. To find a respectable residence was not easy, and Mirabeau and his family became temporary members of the Gassaud household, dwelling in a narrow street not far from one of the city gates. The house that thus became an object of historical interest has little to distinguish it from the other houses that touch it upon either side and line the narrow street,

1 Revue rétrospective (1889), 247.

2 Guibal, i., I 8 . 
little more than an alley, that rises from the city gate. It is three stories in height and stands at the point where the street widens into a miniature square, with a fountain in the centre, from which the women of the town draw water, and a picturesque stone church beyond the fountain, facing the house.

Immediately after the arrival of Mirabeau at Manosque, the marquis received letters from M. Gassaud and from Madame de Mirabeau. In a letter, written from Paris on the I8th of April, I 774, he thanked the former for his kindness in sheltering his son and outlined the policy that he intended to follow.

I have learned [he said], as well through a letter of my daughter-in-law as through your own, of the extreme kindness that you have shown them and the great embarrassment that they have caused you. I have never thought that this would not be an embarrassment for you and what I said to you in this regard in my first letter bore upon many objects; but it did not stand to reason that they could not find some kind of a shelter at first and I did not wish it to be a good one. For, finally, Monsieur, either it is necessary to despair forever of that head there, or, without destroying it and husbanding all the means that may save it, it is necessary to strike it with the effects, amply merited, of public and private severity and to work a revolution in that windmill of pride.

In this plan, Monsieur, the unshakable tenderness and the sweet participation in his pretended misfortunes, but very real for his respectable wife, your company and the wise interest that you have been good enough to show in his lot, are emollients that may, if God wills it, soften his heart and reform his head. This it is that hope, which never entirely loses sight of us, has caused me to conceive, and I count for little, by the side of this last resource, the inconveniences of detail that this sudden change ought 
naturally to operate and I believed that it would lose much of its force if it were expected.

It would, nevertheless be indecent, and what is worse, it would be absolutely unjust, that they should be a burden to you any longer. My brother wrote by this courier to attempt to obtain lodgings at the bailliage of the chateau. I am told that there is furniture there belonging to the state; but I hope that upon my guarantee and more especially upon his, we may be permitted to use them, by means of a regular agreement to put them in a better state than that in which they were received, and it is known that the non-use does more to destroy this sort of things than a proper and regular use. I am writing at the same time to M. d'Estienne-Bourguet, my relative and friend, who is willing to aid me, or, more correctly, to replace me and to act as guide in the immense labyrinth of the verification and liquidation of the debts of this madman, in order that he may form a plan as to the details of their subsistence and give orders in this regard. Add, Monsieur, to the many kindnesses that you have already shown them, that of being good enough on all occasions to write directly to my cousin and to engage $M$. de Mirabeau, for whom he has a very marked veneration, to communicate with him concerning this sort of thing. ${ }^{1}$

The plan of the marquis to occupy apartments in the chateau belonging to the Order of Malta, did not seem satisfactory, as the rooms might be needed at any moment. A house was rented for ten louis a year and Mirabeau was eager to take possession of it, "but it was impossible to make the necessary repairs in time, and his family remained under the Gassaud roof, the expenses of the hospitality being repaid by a regular allowance." 2

1 Mémoires de l'Académie d'Aix (Aix, I861), viii., 392-397.

2 Guibal, i., I 18 .

vol. $1-25$ 
But even in Manosque and "under the hand of the king," Mirabeau did not escape the tribulations due to his thoughtless extravagance. A few days before his arrival in the little town, he was advised by the Jew, Daniel Beaucaire, to whom he owed 60,000 livres, that M. de Limaye had endorsed the notes for the whole of this amount. Mirabeau maintained that he had asked the indorsement of Limaye only for a note of 12,000 livres and that he had later taken up one-half of this sum thus reducing Limaye's liability to 6000 . Whether this is true or not, we have no means of knowing as only Mirabeau's letters have been preserved. ${ }^{1}$ It is highly probable that Mirabeau told the truth. Limaye, although older than his cousin, was a profligate and a spendthrift. He gave his signature for a consideration and it is not at all improbable that, for a consideration, Beaucaire could induce him to indorse the notes that Mirabeau had not asked him to indorse. If Limaye had signed without being asked, Mirabeau had just cause for resentment. He counted upon the reduction to their just value of the debts owed to the Jews; the signature of $\mathrm{M}$. de Limaye made such a course impossible and his honour would require him to free his cousin from all responsibility in the matter.

"What you ask of me, my dear cousin," wrote Mirabeau to Limaye in response to a request that he would sign a declaration that would relieve Limaye, "is only too just, and whatever embarrassments you may have caused me, it is certain that you only wished to oblige me and that I ought to be more thankful than angry at your imprudence. There are, however, 60,000 livres that I might have reduced to twenty-four, and

1 The original is in the collection of M. de Montigny. 
that no kind of favour or of circumstance will permit me any longer to diminish, since you are compromised. Why did you indorse more than I asked you to? I believed that I was doing you a favour, you reply to me and that closes my mouth. My father would be worse than a wild-cat, if he did not settle these debts first." Mirabeau assured Limaye that "there would be no difficulty in securing his discharge," and promised to have Raspaud draw up a paper that would protect him. At the same time, he informed him, that "those rascals were not through with him," and added, "you will be glad, if that is possible, for me to protect myself." 1

Mirabeau's cousin, the wife of Limaye, to whom he was much attached, was ignorant of her husband's act and Mirabeau had agreed not to speak to her of the matter. Unfortunately, the evil news reached her, and she learned at the same time of the dangers that threatened her fortune and of the calumny that attacked her good name. For public opinion "that attributed to her too tender a sentiment for her young and seducing cousin, was ready to seek in this pretended feebleness the explanation of the strange condescension of M. de Limaye. Her solicitude as the mother of a family, her dignity as an honest woman, revolted. She broke out into violent scenes that left her shattered and sick, the results of which were only too sensible in the recriminations of her husband against her cousin." 2

The affair reached a crisis, the week after the arrival of Mirabeau at Manosque. In a letter written the $4^{\text {th }}$ of April, in reply to a letter from Limaye of the $\mathrm{r} 3^{\text {th }}$ of the same month, Mirabeau repeated the assertion of his previous letter that he was not responsible for the

- Mirabeau to M. de Limaye (April 9, I 774).

2 Guibal, i., 120. M. Guibal has treated this affair in detail. 
indorsements of Limaye. "I can oppose to all your protestations," he said, "the very sincere avowal of the gratitude that I feel for your intentions; but also the inculpation, equally formal, of your very evident imprudence." After referring to his early transactions with the Jews, when he had accepted the indorsement of Limaye, he added, "a clap of thunder would not have startled me more than did the tardy avowal of Beaucaire, who announced to me that you had indorsed the note for 60,000 livres that I owed him. The attachment that I have for you, the inviolable and tender respect with which I am penetrated for your wife would have equally prohibited me from being an accomplice in such a folly." His own interest was furthermore opposed to such a course, as it would prevent him from taking advantage of his minority in reducing his debts, and his powerlessness to do so rendered his affairs an inextricable labyrinth. Mirabeau realised that he should have written at once to Madame Limaye, but he had given his word to Limaye to keep the whole matter a secret,

a pledge [he exclaimed] that I should have broken a thousand times, for what other friend, what other counsellor have you in the world besides your wife. . . . It is time to repair my fault and the first duty of an honest man is the truth. I would have liked to spare the feelings of your wife and not give her this whole burden to bear at once. Others have delivered the first blow and my poor cousin has derived no other fruit from her kindness for me than an unworthy falsehood. . . . To her, then, I address myself to confide to her an important declaration, that all $\mathrm{my}$ advisers conjured me not to sign for your interest as well as for my own. She was victorious; I would not let her believe that I am capable of refusing her anything. I will 


\section{Lettres de Cachet and Interdiction}

no longer pay her in lies and she shall know from me the truth of the facts. . . . Furthermore, my dear cousin, the situation is not desperate, nothing is yet dangerous. . . . As to your wife, heaven is less pure than the depths of her heart and I do not feel myself worthy to make her apology; have no fear of the pretended inculpations with which you pretend that the public is imbued and believe that she herself is the best guardian of her honour.

Mirabeau urged M. de Limaye to reassure himself and expressed the hope that he would succeed in bringing his cousin to a more moderate view of the affair. She might do with his declaration what she would, "but as she would want to do only what is wise, she will use it only when good counsel shall have determined the moment. As to diamonds, drafts, and all those bagatelles, that is my affair," he concluded, replying to a criticism from Limaye, "and please heaven, that you may never dispose as lightly of your signature as my wife and I detach ourselves from that rubbish." 1

The same day Mirabeau wrote to his cousin and attempted to make his peace with her. He declared that his justification was found in the letter to her husband that contained "the exact truth." He sent her the declaration, framed after the model sent by M. de Limaye, remarking that it would be "as dangerous for him as for me, as he would be prosecuted and condemned provisionally, the day that he showed it, whereas we could open the mine, if he would allow himself to be guided." He promised to go the following Sunday to the manoir des Jourdans, taking with him a memoir that he would have drawn up. "In any case," he said, by way of consolation, "do not be uneasy

1 Mirabeau to M. de Limaye, Manosque, April 14, I774. 
about the consequences of a debt that is not your husband's and I alone find myself unprotected on account of his indescribable imprudence."

"Speak to me, write to me with confidence," he concluded. "Remember above all, that if the least suspicion affects you still, you have been deceived by the falsehoods of your husband; you owe me the acknowledgment of this, for one does not renounce thus easily the friendship of a man, who, I dare to say it, deserves that you should count upon his inviolable, profound, and respectable attachment." In a postscript, he added that his wife was absolutely opposed to his making out the declaration, and for the sake of tranquillity, he would wait until he had seen Mme. de Limaye and examined the matter with her. ${ }^{1}$ These two letters were accompanied by two others from Madame de Mirabeau to M. and Mme. de Limaye. The virility of the style would seem to indicate that they were dictated by Mirabeau. The countess denied categorically that she had solicited the indorsement of M. de Limaye for her husband's notes and opposed the immediate dispatch of the declaration. ${ }^{2}$

Mirabeau did not go at once to the manor, but waited for the answer of M. de Limaye. It was addressed to Mme. de Mirabeau. "He reproached her brutally with having received jewels from her husband, called the Comte de Mirabeau that man, and for the purpose of confounding him, asked for a confrontation in the presence of Mme. de Limaye." 3 On the 22 d of April,

1 Mirabeau to Madame de Limaye, Manosque, April I4, 1774.

2 Guibal (i., I2I, note 3) quotes the "recueil manuscrit des lettres de la Comtesse de Mirabeau à M. et Mme. de Limaye." These letters form part of the collection of $\mathrm{M}$. de Montigny.

3 Ibid. 


\section{Lettres de Cachet and Interdiction}

Mirabeau wrote again to his cousin, explaining his failure to keep his appointment.

The health of my wife [he wrote], whom I believe enceinte, and all the worry of my new establishment, that I am pressing so much the more as I am a burden to my friends, would have kept me here had not the silence of M. de Limaye, from whom I requested an answer, by Martin, forced me to remain here. But, my dear cousin, I am no longer surprised at the long intervals; time was a necessity to M. de Limaye, whom, by way of reprisal, I will not, however, call that man,-an expression that is at least impertinent-he had need of time, I say, to compose this eloquent prosopopœia that he had addressed to my wife.

As he wished a confrontation, Mirabeau would set out the next morning, but, he said:

I ask of you and recommend to him but one thing. M. de Limaye is fifty years of age, and I am only twenty-five; but above all, he is your husband; so I shall write and I shall remain calm at the manoir des Jourdans. As for him, he gets hot under the collar; it is the ordinary defect of those who are in the wrong. His letter is animated, it is more than animated, it is sometimes insolent, even in speaking to my wife. This tone displeases me more perhaps in a conversation than in a letter. Engage him, then, I pray you, to be civil; let him defend himself with sangfroid. ${ }^{1}$

The following day, Mirabeau was at the manor where a stormy scene took place. On his return to Manosque, he addressed a letter to his cousin, referring to the meeting of the previous day, and sent her the declaration that he had promised her. "You may make of it," he wrote, "whatever use you please, but an indiscreet use of it may injure me seriously. Your

1 Mirabeau to Madame de Limaye, Manosque (April 22, 1774 (?)). 
prudence and your kindness reassure me in this regard and a confidence that is without reserve of any sort." In this declaration, he promised, in case that $\mathrm{M}$. de Limaye was forced to pay the notes that he had indorsed, to repay him and with interest. He made this declaration binding for his son.

I join to this letter [he went on] a writing that I have believed that I owed to your son, but that I beg you never to place in the hands of M. de Limaye. This writing is only a guarantee, of which I hope you will never have need, but as health and youth are not sure guarantees of life, the more I have reflected upon the matter, the more I have felt that it was a matter of strict duty for me to bind my son.

You may not and you ought not to refuse this package. It is a trust that I remit to you and that concerns only your son, or his heir, that is to say, you or his father, if you should have the misfortune to survive him. I avow to you that to send it back to me would be equivalent to an inconsiderate and unmerited expression of contempt for me. How, my dear cousin, can I paint to you at present the effect produced upon me by the violent state in which I saw you yesterday. It pertained to you alone to aggravate still more in my mind the fault of my silence. My dear cousin, I shall reproach myself for it eternally, but you may impute it only to my weakness.

I believed yesterday that I ought to spare your feelings, and I preferred to leave without seeing you, rather than expose myself to the chance of irritating you still more. However great may be the bitterness in your soul, I appeal in this from you to your other self and I await a moment of calm to go to you and renew all the assurances of my devotion. ${ }^{1}$

1 Mirabeau to Madame de Limaye, Manosque, April 24, 774. The document accompanying this letter is found in Guibal (i., I23). I made use of a copy in the possession of M. Mouttet. 


\section{Lettres de Cachet and Interdiction}

But neither Mirabeau's protestations nor his pledges availed to soften the wrath of his cousin. "The following October, this furious Mme. de Limaye, as the countess called her, placed herself, together with her husband, at the head of a coalition that had been formed among the creditors of the count." 1

It was in the very midst of this lamentable affair, that Mirabeau learned by chance that his father was about to deprive him of his independence and place him under tutelage (interdiction). It is in a letter to the Comtesse de Vence, written May 3, I774, that he speaks of this discovery and asks her assistance. The Comtesse de Vence was the daughter of $\mathrm{M}$. de La Rochefoucauld, Marquis de Sugères, and the wife of $M$. de Villeneuve, Comte de Vence. She was Mirabeau's cousin. ${ }^{2}$ Sixteen years his senior, she displayed in his welfare a motherly interest that he repaid by the most respectful devotion. "I respected her as a mother and loved her as a sister," he declared while at Vincennes. ${ }^{3}$ She was a superior woman, possessing a keen knowledge of human nature, great tact and sympathy, and undoubtedly exercised a very beneficial influence over her fiery young cousin.

I regard your arrival at Aix [Mirabeau wrote to Mme. de Vence, May 3, I774], that I learned from M. de Gassaud, as a happy omen, which seems to announce to me some relief from the cruel crisis in which I find myself. I avow to you (and this I confide absolutely to you alone), that, having opened here a package addressed by my father-in-law to my wife, I found in it a letter from my father that she was recommended to hide from me; for

1 Guibal, i., I 24.

2 Mouttet, Mirabeau en Provence, v., 9, note r.

3 Lettres originales de Mirabeau, iii., 322. 
one of the praiseworthy manœuvres of these gentlemen is to engage her to conceal everything from me. This letter, in which my interdiction is announced to her, gives me by its phraseology a gleam of hope, and I have resolved to write to my father on my own account with a most respectful warmth and the most complacent for his ideas. I am sending this letter to you, that you will have the goodness to return, if you find anything to correct in it. In this same letter of my father, he is obliged to avow to my wife, with the air of preparing her, that my respectable uncle has offered very enthusiastically to come to our aid.

He debates the matter with very bad faith, as you may well judge, and in spite of the judicious opinion of my father-in-law, who, to use his own expressions, finds that all my father says is very true, above all that which concerns the bailli. I am going to give my strong and hearty support to the bailli and draw a parallel for him beween the frightful inconveniences of my interdiction and the advantages for all the family of his return to Provence, where none of the scandalous scenes that have taken place would have happened, if he had remained there. This idea which gives support to his own, by a friend in whom he has great confidence, may produce a great effect. [The letter is not clear here, but it would seem that Mirabeau intended to influence the bailli indirectly.]

You will see by the letter that I wrote to Gassier, and of which I take the liberty to send you a copy, my last resolutions in this affair; I submit them absolutely to your wisdom.

I ask of you at present two favours and I hope that your heart will not grow weary of obliging me. Gassier trifles with me, answers nothing but preliminaries to my letters; just now he has written to me and does not explain whether he will draw up the consultation that I have been asking of him for the last week or whether he will not draw it up; deign to see this man; find out what he means and have the goodness to inform me upon whom I may count; stir them up, if you can. Second favour: Romegas will pay his re- 
spects to you without doubt. Have the goodness to speak to him of my affairs; I believe that he is my friend and he is persistent and enthusiastic when he wishes to be. . . I send you the rough draft of my reply. Be kind enough to make your notes on the margin and send them at once to Gassier. Be good enough to guard a copy of it and show it to Romégas. ${ }^{1}$

Not trusting fully to his plan to influence the bailli, Mirabeau was endeavouring to prepare his legal defence, to be used when he should be given a hearing in the course of the proceedings in interdiction. ${ }^{2} \mathrm{He}$ did well to prepare himself, for the preliminary steps had already been taken, and he was soon to be summoned before the judge to give an account of himself.

Two methods of procedure had been proposed in the consultation of December, 1773 : first, to appeal to the courts to have the debts annulled on the ground that Mirabeau was a minor, as in Provence marriage did not release a young man from the authority of his father and the marquis had not given his son his liberty in the marriage contract; if, however, there should be any doubt as to the success of this course, the second course was to have the young man placed under interdiction,

1 Mirabeau to the Comtesse de Vence, Manosque, May 3, 1774. Original in the collection of M. de Montigny; I made use of a copy by M. Mouttet, Mirabcau en Provence, v., 9. M. de Romégas was lieutenant-général of the sénéchaussée of Aix.

${ }^{2}$ In the Lettres originales de Mirabeau (i., 325), is the following reference made by Mirabeau to his appeal to his father and the proof that he had legal advisers: "Je vous suppliai de m'épargner ce chagrin: vous ne le voulûtes pas: je m'y soumis, non que je ne pusse m'en défendre. Vous traitâtes de misérable chicane, ce que je vous mandai à ce sujet. Cette misérable chicane était l'avis de Gassier, le plus fameux avocat d'Aix, et au fond le plus savant: c'était l'avis de Rom [égas]. . . juge fort estimé et mon ami intime qui avec le physionomie d'un bœuf, a la perspicacité d'un aigle." 
to ask for a guardian, and settle the debts at leisure. The second course was the one finally followed, although it was clearly the intention of the marquis to annul the debts contracted with the Jews. On the gth of March, I 774, Mirabeau was twenty-five years old, and, in accordance with the law of France, independent of his father's authority. It was on this very day that the marquis presented to the lieutenant-civil of the Châtelet de Paris the first paper in the proceedings for interdiction. In this document, he recited the facts connected with the marriage of his son and gave the substance of the marriage contract. "Such are the principal clauses of the contract of marriage of the son of the suppliant. They prove that the parents of the contracting parties procured for the husband a very reasonable revenue to maintain honourably his estate, his wife, and their children. But hardly had the marriage taken place, than he delivered himself to the most unbridled and odious dissipation. Although still a minor, he has contracted debts of all kinds by which he has imperilled the liberty of his person, and threatens the ruin of his wife and their children born and to be born." An appeal had been made to the goodness of the King, and the son was at present retained at the chateau de Mirabeau.

The marquis now appeared in the person of his procureur, Paris, asking permission to call together in the office of the judge

a sufficient number of the nearest relatives of the said Comte de Mirabeau and of the lady his spouse (who is also a minor), to give their opinions as well upon the interdiction on account of dissipation (that it is indispensable to pronounce against his son), as for the nomination of an 
acting curator, to which curator shall be given the quality of tutor in actions both personal and real of the said son of the suppliant and of the Comtesse de Mirabeau, his wife, until she has attained her majority, and for the nomination of an honorary tutor and curator, and to agree upon the annuity that shall be fixed to be received by the acting tutor to provide for the support and maintenance of the Comte and the Comtesse de Mirabeau and of their children.

The judge ordered that the parents and friends should assemble in his office at the earliest date possible. ${ }^{1}$

Before having the parents called together, the marquis had sent for the procurations of the D'Albertases, father and son, and of the Marquis de Marignane. He had evidently supplied them with the text of the documents; the wording is the same in both. The procuration of the D'Albertases was undated and uncertified to; a reflection upon the legal knowledge of the first president of the parliament of Provence. From another source, we learn that the paper was signed February 21, I $774 .^{2}$ The procuration of the Marquis de Marignane was drawn up March 19 th, by M. Sacoman, the royal notary of Marignane, properly witnessed, and on the following day, at Aix, M. Audiet, lieutenant-général of the sénéchaussée, certified to the authority of M. Sacoman. In both procurations, the names of the persons to whom power was given were omitted, a blank being left for the reception of the name.

1 The following account of the interdiction of Mirabeau, the first detailed account that has ever been written, is drawn irom the documents in the Archives nationales, Y, 499x. The documents are contained in a "paquet" bearing the inscription, "Avis, juin, r 774. Y, 499r." As I have already stated, a number of the documents have been published by M. Alfred Bégis.

2 The date is given in the document of March 29, I774. Archives nationales, Y, 499 I. 
After reciting the titles of the marquis or of the D'Albertases and the relationship to Mirabeau, the documents went on to say that,

being informed that the Marquis de Mirabeau, his father, in order to have annulled the acts of dissipation that have been performed by the said Comte de Mirabeau, which are public, already immense, and such that they may lead to his ruin and that of his wife and children, as well as to anticipate and prevent the depredations that he may make hereafter, and that are so much the more to be feared as he approaches the time of his majority [he was already major when this document was drawn up], the said marquis, giving power of attorney, has authorised . . . to appear in all gatherings that shall take place in Paris at the office of the lieutenant-civil at the request of the Marquis de Mirabeau, father, protector, and legitimate administrator of the person and goods of the said Comte de Mirabeau, and to declare that it is his opinion that he be and remain interdicted from all management and administration as well of his property as of that of the lady his spouse, and that there shall be named an acting tutor who shall be indicated by the said M. le Marquis de Mirabeau, under the authority and by the instructions of whom the acting tutor shall act (as well for the purpose of annulling the acts performed by the said Comte de Mirabeau, up to the present time a minor, as for the future). Which interdiction the said M. le Marquis de Mirabeau is of the opinion should last for the time during which the said acting tutor shall be engaged in saving the revenues to pay the debts recognised as legitimate; and until the entire liquidation of these, the honorary tutor shall employ annually the sum of 3000 livres for the maintenance of the said count and of his house, apart from and independent of his residence in the chateau de Mirabeau, to which he is relegated by order of the king.

The 29th, of March I774, the Marquis de Mirabeau, 
the Bailli de Mirabeau, the Marquis de CastellaneEsparon, and Vicomte de Castellane-Esparon appeared before the royal notaries Baron and Bro in Paris, and the last three gentlemen conferred powers of attorney upon M. Jean Baptiste Paris to act for them in the assembly of the relatives at the office of the lieutenantcivil of the Châtelet. He was authorised

to say and declare, as the said seigneurs have just done to the undersigned notaries, that they have taken cognisance of the immense acts of dissipation of every kind performed by the said M. Comte de Mirabeau and which amount already, from what is known of them from the statement that has been made, to nearly 200,000 livres for the year that has passed from his marriage up to the present time; that in consequence they are of the opinion that the said M. Comte de Mirabeau should be interdicted and deprived of the management and administration as well of his own goods and personal affairs as of those of the lady his spouse, still minor, and this to avoid and anticipate the entire and prompt ruin as well of the said $M$. Comte de Mirabeau as of the lady his spouse and of their children, born and to be born; and that the said M. Marquis de Mirabeau, natural administrator and master of the person and of the goods of the said M. his son, in virtue of the paternal power admitted in the county of Provence, place of origin and establishment of the family of the said M. Comte de Mirabeau and of the situation of their principal properties, be, in whatever may be necessary, named curator to the causes and honorary tutor to the said interdiction, and that M. Raspaud, advocate before parliament and notary at Aix, be elected and named curator and acting tutor to the said interdiction in order, under the authority and inspection of the said M. Marquis de Mirabeau, father, to manage and administer the property and affairs of the said M. Comte de Mirabeau, the son, and those of the lady, his spouse, to receive their revenues now due or to become due. 
As long as this interdiction shall last, he shall employ up to the sum of 3000 livres for the maintenance and nourishment of the said M. Comte de Mirabeau and of the lady, his spouse, and of their establishments, save, however, to augment the said sum by 3000 livres under the orders and by the authorisation of the said M. Marquis de Mirabeau alone, as also to employ the excess of the annual revenues, that may amount to 6000 livres, in the payment of the debts that shall have been legitimately contracted, after the examinations and investigations of the said debts shall have been made by the said M. Raspaud, on the instructions of the said M. Marquis de Mirabeau, the father; in consequence to take cognisance of the nature and amount of each of the said debts, to secure letters of rescission for those that shall have been found illegal, prosecute the ratification of the said letters of rescission in order to have declared null the said illegitimate debts; to form all demands or to forbid prosecution of anything until definite judgments and decrees have been rendered; to render account of all requisitions to the said M. Marquis de Mirabeau, the father, of the said management and administration, who will pay him what he may judge fitting for his honoraries and generally do all that may be necessary for the welfare and advantage of the said M. Comte de Mirabeau and of the lady, his spouse.

It will be noted that while the procurations sent from Provence assign Mirabeau 3000 livres together with the residence at the chateau, the authorisation given to Paris in this document provides for a possible increase of 3000 livres, but says nothing about the chateau. According to these instructions it was possible for the marquis to limit his son to 3000 livres a year and require him to provide his own residence. The reason for omitting all mention of the chateau from these instructions was that the lettre de cachet, transferring Mirabeau to Manosque, had already been issued. An- 


\section{Lettres de Cachet and Interdiction $40 \mathrm{I}$}

other matter of importance is the statement that there may be a possible 6000 livres to apply to the debts. In accordance with the marriage contract, this was the revenue for the first year; it was to increase by five hundred livres a year, beginning with $\mathrm{r} 773$, and to continue for five years, until in the last year the revenue of Mirabeau and his wife would have been $x I, 500$ livres. The marquis was evidently planning to reserve the increase for himself.

The same day on which this act was passed before the notaries, the marquis and M. Paris appeared in the afternoon before the lieutenant-civil of the Châtelet. Paris presented the procurations of the D'Albertases and the Marquis de Marignane and affirmed that he was authorised to represent them. Notwithstanding the fact that the blanks were not yet filled in, the papers were accepted, attached to the record, and Paris was allowed to act for the relatives in Provence. Paris, thereupon, presented the procuration drawn up the same day, authorising him to act for the relatives in Paris, and this was also accepted. M. Dufour, the judge, "gave act and ordered that the said M. Comte de Mirabeau should be questioned upon the facts of dissipation in question by the royal judge the nearest to the place of residence of the said M. Comte de Mirabeau, for which our present ordinance will serve as a commisssion to conduct the inquiry."

A month passed before any further steps were taken. The scene changed to Provence. An order was issued on the 3 oth of April by the chancellor of the parliament of Aix to the bailiffs of the parliament, in the name of the King, to execute the ordinance rendered the 29th of March by the Châtelet of Paris. The instructions were issued at the request of the Marquis de Mirabeau.

voL, $I-26$ 
Forcalquier, twelve miles north of Manosque, was the residence of the nearest judge having jurisdiction in the case. The occupant of the office at this time was Joseph Escuyer "councillor of the king, lieutenant particulier civil, occupying the tribunal, holding the place of the lieutenant-general." It was before this individual, that appeared on May 7, I774, M. Berluc Neveu, "procureur of the sénéchaussée, intervening in the name of M. Victor Riqueti, Marquis de Mirabeau," who, after remitting to the judge extracts of the proceedings in Paris and the letters of pareatis issued at Aix, April 3 oth, required him "to proceed at once to the city of Manosque and to the house of M. Jacques Paul de Gassaud, where lodges at present the said M. Comte de Mirabeau, for the purpose of interrogating and giving him a hearing touching the facts of dissipation with which he is charged." Whereupon the judge announced that he would proceed the next day, accompanied by his clerk and suite, to Manosque to conduct the hearing.

The $9^{\text {th }}$ of May, court was held in the house of M. de Gassaud. Mirabeau was duly sworn and questioned as to his name, surname, age, quality, and residence. After answering these questions, he at once protested against

the competence of the tribunal in the name of which he was interrogated, tribunal distant one hundred and fifty leagues from the province that he had inhabited with a continuous residence since his marriage, province where alone are found his creditors and the proofs of his debts. It was not that the said M. Riqueti pretended to invalidate the will of his father, that he regards as an irrevocable and sacred law; but he hopes to prove, at least, by his protestations, that his submission ought to be attributed only to his filial 


\section{Lettres de Cachet and Interdiction}

respect, because he was not ignorant of the means of defending this case before the tribunals.

Questioned as to the amount of his debts, Mirabeau attempted to take the proceedings into his own hands, demanding of the judge a statement of the questions that were to be put to him and permission to present a history of his debts before replying in detail to the question. The judge insisted that the question should be answered. Nevertheless, Mirabeau presented his apology before giving the answer that the judge demanded. He began by

invoking the paternal clemency, in these responses that will be without doubt placed under the eyes of my first master, of my natural judge. It is of him that I dare to ask if my heart is bad and hardened, if the disorders of my past conduct prove unanswerably and forever the delirium of my head. It is of him that I dare to ask what men would not have been lost if, judging them by the escapades of their youth, however wild they may have been, inferences had been drawn from them concerning their maturity. Yes, my conduct has been foolish and reprehensible, I do not blush to acknowledge it. Let the judge deign to hear now the observations that may attenuate my errors, diminish their consequences, and suspend the decree that the court is preparing to pronounce against me.

Mirabeau then recited the history of his debts. The larger part of what he said has been utilised in the preceding chapter. The speech had evidently been prepared and was copied upon the records. It was probably the result of the advice of Gassier and Romégas. That, at least, is the inference that seems to be justified by the form of the procès-verbal and by a statement in the Lettres de Vincennes. This exordium was 
more for the benefit of his father than for that of the judge. He interrupted the recital to appeal to him. He plead in justification, in defending his expenditure on the famous chamber at Mirabeau, that it was not as bad as if he had gambled the money away. "There are few young men," he exclaimed, "who in their lives have not lost 20,000 livres at play." Mirabeau never was a gambler.

One question more [he said in concluding his recital], and I submit all that has preceded, my personal liberty. my reputation, my honour (and all these moral possessions are dearer to me than life), I submit them all to my father, whose tribunal I shall never refuse to acknowledge. May one reason with justice from the conduct of a youth of twenty-three, to that of a father of a family, may one even infer anything from the impetuousness of youth, from year to year, for a man who is neither without good sense, nor without bowels, and who, in less than a year, has experienced all the anxieties, all the humiliations of derangement, has seen himself forced to drag his wife into the abyss, and has compromised thus the life of a cherished wife, a mother and nurse, the tranquillity and happiness of his father, of his uncle, of his father-in-law, of all those that are dearest to him in the world? No, I dare to say it, one may not; and I would plead this cause for a friend before all tribunals. I appeal from them to you, my father, for your heart is as just and more indulgent than all the tribunals of the universe. I will not repeat here what I have ventured to write to you. I want you, you alone for my judge. I have said enough to you about it to awaken your paternal tenderness; it will be my best advocate; I do not wish either to talk to other magistrates or to withdraw myself from your authority. ... I I have ventured to offer you, and I depose formally in the hands of the public minister, the offer that I make to pay my debts, with the sums of 20,000 écus cash, 


\section{Lettres de Cachet and Interdiction 405}

the interest of which will be taken from my revenues, and to arrange with my creditors, not usurious, to reimburse them annually from what remains to me the sums that I may owe beyond the 20,000 écus. If my past conduct does not permit you to allow me to dispense that sum, deign to confide it to whomever it may please you to name. Furthermore, are you not my father? Who may withdraw me from your authority? May not the public minister always exercise a surveillance over me and restrain me? What guarantee will you ever have of my reformation, if you deprive me of my civil existence? This is the last test that you owe me and that you owe yourself.

After reading this plea, it is possible to understand what the marquis meant when he ironically remarked that his son always wanted to be reasoned with and that he reasoned beautifully.

His explanation made, Mirabeau acknowledged that he owed

in all, some two hundred pistoles, 188,624 livres, as is shown in the memorandum, written in my own hand, and that I request to have added to the record. This sum is thus composed: The merchants and individual creditors lay claim to the sum of 46,794 livres; 2 , I have contracted obligations to the amount of $7 \mathrm{r}, \mathrm{I} 75$ livres, in recognition of money loaned upon securities; 3 , I owe 4378 livres for debts contracted for food or for the wages of rural labourers; 4 , I have contracted with the Jews obligations to the amount of ${ }_{136,275}$ livres, namely, 70,179 livres of drafts due and 60,096 livres of drafts not yet due; these four heads compose the total mentioned above.

In response to the question who his creditors were, he replied that, consulting only his memory, he would confine himself to saying that they were merchants of Aix, Lyons, Marseilles, and Jews domiciled at Aix, 
Cavaillon, or Isle; that it ought to be presumed, from the minute exactness of his memorandum, that he had an exact and circumstantial record of his credits and consequently of his creditors, a record that he was ready to deliver whenever and wherever his father should deign to ask for it; but that eight or ten pages would be necessary to insert the details.

The interrogation then turned upon the debts owed to the Jews. Mirabeau stated that he had received from Jacob Beaucaire-not to be confounded with Beaucaire brothers-230 louis, as shown by a letter from Beaucaire in the possession of Raspaud. He then referred to the difference between the sums that he had signed for and those received ${ }^{1}$ and also to the jewelry that he was forced to take. Among his Jew creditors were Daniel Beaucaire, David Cremieu, Michael Rougel, M. Giraudel, David Beaucaire, and Jussaud Lyon.

$\mathrm{He}$ was then questioned upon the sale of furniture and wood at the chateau and upon the disposition made of the diamonds of the countess. At the conclusion of the interrogation, the record was read to him and Mirabeau acknowledged that it was a true record and affixed his signature to it.

1 I find the following interesting foot-note in Mouttet, Mirabeau en Provence (v., $\mathrm{r}_{3}$ ): "N'avons-nous pas vu, il y a quelques années, sur les bancs de la cour d'assises d'Aix, un jeune homme, que sa situation de famille avait placé, presque à l'age ou les autres débutent, à la tête d'une grande administration maritime, qui lui permit un jour de demander par télégramme du Cercle de la rue Royale de Paris, la somme énorme de 80,000 francs qu'il recut sur 1'heure; il abusa tellement, qu'il en arriva à signer pour 180,000 francs de billets, quand on ne lui donnait que 18,000 francs." Mirabeau always maintained that his debts to the Jews could be legally reduced to a small part of their face value. This was also the opinion of his uncle. Although his father always quoted them at their face value, there is evidence that he would have gladly repudiated them. 
The interdiction of Mirabeau was asked for on the ground of dissipation, meaning by that, not that he had gambled, not that he had been dissipated, but that he had spent more than his income and had fallen deeply into debt. The marquis had supplied no evidence upon which to support his case; the interrogation was supposed to supply that. How much did Mirabeau really owe? From his own statement, he owed about 200,000 livres, estimating the two hundred pistoles at 2000 livres. This is probably correct. ${ }^{1}$ It agrees with the statement made by the Marquis de Marignane in his letter addressed to Mirabeau March I3, x 774. "Permit me to observe to you," he wrote, "that I have had under my eyes this morning a statement of your debts amounting to 187,000 livres, that there are many not included in this statement, on account of which I believe there would be something gained in fixing them at 200,000 livres." 2 In 1782 , the bailli estimated the debts at $16 \mathrm{r}, \mathrm{Ir} 6$ in 1776 , after 40,000 livres had been paid. ${ }^{3}$ In another letter of the same year, he quoted the marquis as giving the total as 2 I 2,640 livres. $^{4}$ About 200,000 livres, then, would appear to be correct.

This is, however, the amount of the nominal debt. The sum for which a settlement could be made was

1 In Observations sur un libelle diffamatoire ( $\left.\mathrm{r}_{7} 8_{3}\right)$, $\mathrm{r} 44$, Mirabeau makes the following statement about his debts: "Au mois de juin 1775, M. le Marquis du Saillant, mon beau-frère, vint en Provence, assembla mes créanciers, composa un état de toutes mes dettes, qui montaient, suivant cet état, à r $6 \mathrm{r}, \mathrm{r}$ r 6 livres, 8 sols, $\mathrm{r}$ denier, y compris les lettres juives et usuraires qui étaient un objet de plus de 80,000 livres. Tous les créanciers, un seul excepté, consentaient à être payés en huit années, sans intérêt."

2 Guibal, i., rr3.

3 Correspondance genérale, $\mathrm{x} ., 446$. The bailli to the marquis, Aix, December 25, 1782 .

- Ibid., x., 74. The bailli to the marquis, Aix, August 20, r78I. 
quite a different matter. Mirabeau frequently asserted that his debts could be paid for 60,000 livres, ${ }^{1}$ being largely usurious. This statement seems to be not far from the truth, for the legitimate debts. In I778, while Mirabeau was at Vincennes, the bailli, writing to the marquis concerning the debts of his nephew, warned him not to pay anything to usurers, as his son, taking refuge behind his minority and his interdiction "might claim what had been paid in this way for him, and as he knows very well that all these debts weighed at their just value would not amount to 70,000 livres, he would be almost excusable." 2 According to the marquis, the debts-doubtless excluding the sums owed to the Jews-amounted originally to 60,000 livres. $^{3}$ In another place the bailli quotes his brother as saying that debts amounting to 212,640 livres could be reduced to 69,000 and does not see how it could be done. Even if the debts owed to the Jews, amounting to II 5,000 livres, were reduced to 36,000 , there would still be 79,000 unaccounted for. ${ }^{4}$

1 Lettres originales de Mirabeau (i., $3^{16}$ ), where he speaks of sixty or seventy thousand livres; Observations sur un libelle diffamatoire ( 1785$), 144$, he states that " avec 60,000 livres, on aurait par conséquent éteint 105,000 livres de dettes: et la masse aurait été reduite à 46,1 r 6 livres." On the same page, he states that "ces 60,000 livres auraient $p \hat{\text { et }}$ du être employées à éteindre mes dettes les plus légitimes, et mes dette usuraires dont une grande partie n'était pas encore échue."

2 Correspondance génerale, viii., $32 \mathrm{I}$. The bailli to the marquis, Mirabeau, November 2, 1778 .

3 Ibid., i., 52. The marquis to the bailli, Bignon, August 8, $178 \mathrm{I}$. In this letter, the marquis, after stating that Du Saillant had estimated the debts, as he remembered, at 69,000 livres, added "Il est vrai qu'on mettait à part et à rien toutes les dettes juives, comme c'est bien encore mon objet de les faire canceller."

"Ibid. x., 69. The bailli to the marquis, Aix, August 20, I $78 \mathrm{r}$., 
It was the intention of the marquis to pay the debts to the Jews by "passing the sponge over them."1 These debts, being usurious, were in a class by themselves. Even the bailli, honest man that he was, looked upon such a course as perfectly correct, "for almost the whole lot are either absolutely usurious or they took advantage of his state of folly to gain some advantage for themselves." 2 The debts owed to the inhabitants of Beaumont and of Mirabeau formed an exception and constituted a privileged class. ${ }^{3}$ On the ground that Mirabeau was a minor when the debts were contracted with the Jews, the courts were to be asked to annul them. This was the intention of the marquis in 1773 , as I have already shown; it was his intention in 1782,4 but he took no steps to put it into effect.

The proces-verbal of the interrogation was sent to

1 Correspondance génerale, viii., 246. The marquis to the bailli, Bignon, July I I, 1778 : “Mais songe après, je t'en prie, que la plus importante de la maison, c'est d'arranger l'histoire des créances de ce forcené pour faire passer l'éponge des tribunaux ensuite sur toutes les créances usuaires."-Ibid., viii., 279. The marquis to the bailli, Bignon, August 29, 1778 : "Ce ne serait pas la peine de s'arranger avec aucuns créanciers, si l'on ne pouvait tout de suite faire passer l'éponge sur les autres par la force et pleine séverité de la loi."

2Ibid., viii., 309. The bailli to the marquis, Mirabeau, October 6, 1778 .

3 Ibid.

- Ibid., viii., 279. The marquis to the bailli, Bignon, August 29, I778: "Ce mauvais sujet avait interdiction prononcée ou instigué [the marquis corrects himself, for the interdiction was not pronounced until Mirabeau had come of age] avant sa majorité. D'ailleurs je ne l'ai pas émancipé par son contrat de mariage, ainsi selon nos lois, il était et il est toujours mineur."-Ibid., vii., 62. The marquis to the bailli, Coulomb, December 24, I773: "Quant à notre fol, toutes ses dettes dans ce pays même seraient sans valeur comme fruits de minorité." 
Paris. After reading it M. Dufour added a note to the document on May 29 th, ordering that it be joined to the proces-verbal of March 29 th and laid before the procureur of the king that he might give his opinion upon the case. Thereupon, M. Dufour would make his report in the council chamber. The record shows further that on the 3 Ist of May M. Mereau, procureur of the king, expressed himself in favour of the petition for interdiction, and that on the 8th of June, I774, M. Dufour, with the agreement of the council, pronounced the decree that rendered Mirabeau a minor to the day of his death. "The said M. Gabriel-Honoré Riqueti, Comte de Mirabeau," ran the decree, "is and shall remain interdicted and deprived of the management and administration as well of his goods and personal affairs as of those of the said lady, Marie Marguerite Emilie de Covet, his spouse; in consequence we forbid him to pass or to sign any acts, either before notaries or privately, on pain of nullity." The marquis was appointed honorary curator and M. Raspaud acting curator, the condition under which the office was to be undertaken and the revenues allotted to Mirabeau and his wife, being literally the same as those contained in the petition of the marquis. Finally, it was ordered, "in order that these presents may be notorious, that they be recorded and notice of them be given to the notaries of this city and to those to whom it may pertain and the name of the Comte de Mirabeau be transcribed on the list of the interdicted." On the roth of June, I774, the Marquis de Mirabeau appeared before Dufour and was duly sworn in as honorary curator of his son.

Mirabeau had not willingly submitted to this humiliating deed, and it may readily be believed that he did not exaggerate, when he wrote to his father in later 


\section{Lettres de Cachet and Interdiction 4I I}

years that it was a "terrible blow" 1 to him. The limit of the interdiction was not set and its termination depended upon the good pleasure of the father, who alone could pay the legitimate debts and begin the action for the annulment of the usurious debts. What course the marquis took will be shown in the following volume. The evidence thus far presented would seem to justify the statement that June 8 , I 774, was one of the most critical dates in the life of Mirabeau.

2Lettres originales de Mirabeau, i, 325 . 


\section{CHAPTER XV}

\section{TWO AFFAIRS OF HONOUR}

I was not without reason that the expression "children born or to be born" appeared so frequently in the documents of the process for the interdiction of Mirabeau. In the spring of 1774 , it was evident that the Comtesse de Mirabeau was about to become a mother for the second time. Before the birth of the child, the father, living on a mere pittance, about to be declared a minor and incompetent to administer his own affairs, endeavoured to provide for its future, if it proved to be a boy and thus a younger son. "I assured myself," he wrote to his father from Vincennes, "of the funds necessary for the reception of my child at Malta, if its sex permitted it to enter there. For four per cent. I secured this money, that I left on deposit until the event." 1 In the same month, however, in which he was submitted to the interrogation concerning his debts, he became the possessor of a secret that robbed the anticipation of approaching paternity of all pleasure and added the last tragic touch to the misery of his situation. The last week in May, I774, there fell into Mirabeau's hands a letter from young Gassaud to his wife. It was written in Paris. A skilful interpretation of the text convinced him that she had been unfaithful to him; he accused her and

1 Lettres originales de Mirabeau, i., 325. 
she confessed. A stormy scene followed. The countess fell upon her kness, clasped his feet, and begged his forgiveness. The state into which the letter cast him bordered on madness. The storm of anger, of outraged pride and of disappointed affection-for Mirabeau undoubtedly loved his wife at this time-once past, he forgave her. ${ }^{1}$

It has been generally supposed that the infidelity of the Comtesse de Mirabeau was one of the consequences of the exile of Mirabeau to Manosque, where his wife was thrown into the company of the young musketeer Gassaud. ${ }^{2}$ A more careful examination of the evidence has made clear that this view is not correct. ${ }^{3}$ M. de Gassaud had left for Paris in April

1 See the letters of Mirabeau and of his wife given below in the text.

'Loménie, iii., ro9; Stern, La vie de Mirabeau, i., 98.

${ }^{3}$ M. Mouttet, in his manuscript volume, Mirabeau en Provence, has treated this question in a convincing manner. The substance of the argument is this: When Mirabeau and his wife went to Manosque, April ro, I 774, young Gassaud was no longer there. The letter of the marquis, addressed to the father of the young man, written at Paris, April $\mathrm{r} 8, \mathrm{I774}$, is proof of this: "Je ne me suis pas trouvé chez moi," he wrote, "quand M. votre fils me fit l' honneur d'y venir. Mon frère fut plus heureux, et il en reçut la lettre que vous me faites l'honneur de m'écrire en date du 6 du courant." Gassaud must have left Manosque for Paris several days before the arrival of Mirabeau. He did not return to Manosque until after the discovery of the infidelity of Madame de Mirabeau. The letter that Mirabeau intercepted was a letter that Gassaud wrote from Paris to the countess. That letter Mirabeau burned before the eyes of his wife. The original of the reply, dictated to the countess by Mirabeau, exists. It bears upon the back the address, "A Monsieur, Monsieur de Gassaud, Mousquetaire dans le Ière Compagnie, à l'Hôtel des Mousquetaires à Paris." Gassaud had left Paris before the arrival of the two letters addressed to him by Mirabeau. This is shown by the address of the dictated letter; the word Manosque had been substituted for Paris, evidently by some one in Paris. The evidence seems to be convincing that the infidelity of the countess occurred before the residence at Manosque. 
before Mirabeau and his wife had reached Manosque. It was probably as a guest at the chateau that Gassaud violated the laws of hospitality by making love to the young wife of his host. And when it is remembered that Mirabeau's infant son was but a babe in arms, it may be possible to sympathise with the outraged father. In his calmer moments Mirabeau seemed to realise that this discovery must remain a secret and that nothing would be gained by giving vent to his anger. The affair between his wife and Gassaud must, however, be brought to an end. At his dictation, she wrote to Gassaud, informing him that their secret had been discovered and that he must not see her again.

At last, Monsieur [ran the letter], I have recovered my senses. The first effect of my return to virtue is to inform you that all relations between us are at an end. Chance has permitted your letter to fall into the hands of my husband. I had not waited for this moment to confess my errors, and the personal moderation that he has shown toward me in this whole matter leads him to ask me to pray you not to return to this place so long as we shall be here, as much because it is no longer possible for me to see you, as on account of my husband. I do you too much justice to believe that I shall have need to ask of you the two letters of mine that you have as well as the portrait and this [letter]; I hope that you will be good enough to send them to me. 1

The letter was written on May 28, I774. Probably on the same day, Mirabeau himself wrote to the seducer of his wife.

A letter in my handwriting [he began] ought to be a stroke of lightning for you, if honour is not entirely stifled in

1 Copy of letter in Mouttet, Mirabeau en Provence, Chapter v. 
your heart. I am, then, your most cruel enemy [evidently a quotation from the letter of Gassaud]; I, who have displayed so much interest in you and so much activity in serving you, I who conquered the strongest antipathy against you, an antipathy aroused, no doubt, by a most frightful presentiment. Yes, I am your most cruel enemy, for such is always the one that we have outraged. Great God! what a rascal you are! You for whom hospitality, confidence, gratitude are nothing; you who did not have the courage to attempt to kill me and who had the abominable consistency to tear from me a thousand times more than my life. Vile seducer! a wife that I adored, and you knew it; a feeble creature that pusillanimity has ruined; a poor unfortunate, from whom you have taken every form of happiness, for none is possible with the remorse of this thing. . . Unfeeling one, did you think to deceive me? An honest heart is deceived for a long time, for it knows not distrust; but your awkward subterfuges, which are not far removed from madness, ought to have opened my eyes; ah! who had told you that I would not plunge a dagger into her breast; that I would not cast her into a sombre dungeon? Barbarian, who sacrifice to your brutal and unrestrained desires all the virtues and the most innocent of all women. Ah! who gave you the right to deprive me of the pleasure of becoming once more a father?

Unworthy mortal, you who dare to judge a man who has never resorted to violence but when honour has been compromised, you who plunge yourself into the mire of infamy, do you know what distrustful and irritated honour is? Well, then, I am about to teach you.

You had no more prudence than honour, and I divined a thousand times the abyss into which you were going to plunge me. I trusted this unfortunate woman and I warned her of the danger; my warnings were frequent, she replied at last in an irritated manner and I became angry. I wished you to know it. The fear of injuring you in the minds of your parents arrested me. Your cowardly hypo- 
crisy, your false confidence, all the ruses that your infernal soul made use of before departing for Paris, reassured me; I would have believed that I committed a crime in suspecting friendship of treason. . . . Great God! I parted from you in the arms of perfidy.

Your affairs became my dearest idol; they always have been. Their discussion became, through the indecision of your uncle, a source of disgust that I overcame. I triumphed over him and I avow that I did not believe that I was your most cruel enemy. . . . The most unbelievable imprudence caused to fall into my hands a letter, the first line of which threw me into a condition from which I have not yet recovered and that threatens me with madness. An unfortunate creature, that I could annihilate, cringes at my feet and embraces them; I see her remorse, her repentance disarms me. I recall her sex, her age; all my fury falls upon the villain who has ruined us both.

But is it necessary to destroy him? No, I have only to speak to his uncle and his fortune will be taken from him; his father will be his executioner. Such vengeance is not mine; but to complete the horror, I cannot resolve to deprive of life a mortal, infamous, it is true, but the son and nephew of all those I respect and honour.

Unfortunate being, if your conscience were not the cesspool of all the vices, it would be your most inexorable executioner; for I know from my own condition, I who have nothing to reproach myself with, what is, what ought to be, that of a man soiled with crimes and surrounded by the evils that he has wrought. . . . But you were not so formed as to be sensible to this torture.

It matters not; your father and your family save your life; but never appear before my eyes, for may a thunderbolt annihilate me, if I do not exterminate you.

P. S. Doutbless you do not want me to go to Paris to get those three letters, this one and a portrait. ${ }^{1}$

1 Copy in Mouttet, Mirabeau en Provence, Chapter v. 


\section{Two Affairs of Honour}

There were violent scenes in those days between Mirabeau and his wife. It was, without doubt, at this time that, in response to her exclamation, "I know very well that you will end by having me locked up," he replied, in a calm tone, "No, I would kill you sooner." $1 \mathrm{He}$ turned for comfort and advice to Madame de Vence, then at Aix. His letters have been destroyed, but from her replies we learn something of his state of mind and of his purposes. His first letter simply informed her that he had a secret to confide to her. "You frighten me exceedingly, M. le Comte," she replied to him, "and the disorder of your letter troubles me more than I can express to you. What has happened to you? Do not delay, I beg you, to intorm me of it. Until then I can say nothing to you, being absolutely ignorant of the new addition to your troubles." 2 On the receipt of this letter, Mirabeau sent Madame de Vence the letter of Gassaud to his wife.

The revelation affected her deeply.

How sorry I am for you [she answered], and how you deserve to be pitied! By what misfortune has this fatal letter fallen into your hands? It is going to poison forever your own life and that of your unhappy wife, whom I pity even more than you, since she is condemned to the most frightful torment, that of remorse. Do not aggravate her sufferings by letting her know the extent of yours. Remember that she is more unfortunate than culpable, more feeble than criminal, and that you have yourself exposed her to the point where she has ended by succumbing. It is not that I pretend to justify her errors; I am sure that she knows the extent of them as well as myself and that she

1 Lettres originales de Mirabeau, iii., 37 r.

2 Madame de Vence to Mirabeau, probably written the last of May, I 774. Copy in Mouttet, Mirabeau en Provence, Chapter v.

vol. $1-27$ 
detests now the seducer who deprived her at the same time of her own self-respect and of that of her husband. But the more unpardonable her fault is, the more merit you will have in pardoning her. By that, you will assure forever her love, her respect, and her gratitude and all your rights will acquire new strength from it. How could you think of destroying an unfortunate being whose senses have surely been seduced more than her heart and who has not found in her education any principle that would have taught her to be on guard against herself? From the time that she was born [Madame de Vence had known Mlle. de Marignane from her childhood] she has had under her eyes only bad examples; you yourself have sought to destroy the little religion that was taught her at the convent. The thing has happened that happens to three fourths of the women that differ from Madame de Mirabeau only by a little less imprudence; but I realise that it is frightful to be certain of it and not to be able to dissimulate what so many others make a pretence of ignoring. This last suffering was reserved for you, but remember that you will be contributing to augment it, if you cause any suffering to your wife.

Your conduct toward her, up to the present time, has been admirable; continue in the same way, I beg of you; appear to forget what she will remember only too often; let your anger fall entirely upon the infamous suborner who has seduced her, but see in her only the mother of your son, who will employ all the moments of her life in causing you to forget her fault. I do not pretend to diminish it; reflect a little, I beg you, upon the inequality that prejudice has placed between the man and the woman and how unnatural it is that that which is permitted to the man should be so rigorously punished in the woman, who, very often, simply follows the example that her husband has given her. Do not believe that I conclude from that that Madame de Mirabeau is less culpable; it is not in accordance with my principles that I reason, but solely in accordance with those 


\section{Two Affairs of Honour}

inspired by a lack of religion. I have little faith in the virtue of women that have none, and you did very wrong to destroy that of your wife. The misfortune that has come to her will recall it. Leave her this consolation; I would I might procure some consolation for you, but in the condition in which you are, there is little that is efficacious. I can only assure you of my participation in all your troubles; do not fear to confide them to me; they will be buried in the most profound secret and you will never find anybody that will take such a genuine interest in them.

I return to you the fatal letter; I confess that I was tempted to burn it, but a moment of reflection led me to see that it would be doing an injury to you. This merit belongs to you. I exhort you to it with all my heart. It is for the goodness of yours to efface even the last trace of all which may recall to you such cruel memories, by burying this unhappy knowledge in the most profound forgetfulness; the tranquillity of your life depends upon it and I have that in view, in giving you this advice, as much as that of your poor wife, whose situation appears to me even more frightful than your own. In the name of God, have pity upon this unfortunate being, whose life will be shorter than you imagine. ${ }^{1}$

Again on the $9^{\text {th }}$ of June, Madame de Vence wrote to Mirabeau urging him to forget what had happened.

Be assured [she said] that I do not abandon the innocent for the guilty, but the interests of the two seem to me to be so bound together that I cannot separate them, and I believe that I am rendering a service to both of them in counselling you to throw the thickest possible veil over the past. It is only in the most profound forgetfulness that you can recover your tranquillity and you would have some confidence in my advice if you would render justice to the

1 Madame de Vence to Mirabeau, probably written the last of May, I 774. Copy in Mouttet, Mirabeau en Provence, Chapter v. 
sentiment that dictated it. Believe me, M. le Comte, I should never think of giving it to you, if it were inspired by any other motive than the most sincere attachment. ${ }^{1}$

The conduct of Mirabeau in the days that followed was such as to win the praise of his cousin.

I admire you [she wrote on the I2th of June], and I assure you that it is with all my heart. It is impossible to conduct oneself better than you have done, and your moderation on so critical an occasion does honour as well to your heart as to your reason. It must be confessed that you deserve some credit for it, and, however good the opinion I had of you, I acknowledge in good faith that I would never have dared to hope you would be master of yourself to such a point. This self-control appears to me a very good omen for all the rest and I shall begin to believe you more culpable when you are in the wrong, for I see that you can do what you will and that you wished to do what was best and most honest. The more that has cost you, the more I esteem you, and if this sentiment on my part has any value in your eyes, I assure you that you have nothing to desire in that respect. ${ }^{2}$

The storm seemed to subside, and the countess, apparently grateful for the consideration that her husband had shown her, wrote to the marquis, seeking to soften his resentment toward his son. Her letter bore the date June I 4 th; the knowledge of the final action of the châtelet had not yet reached Manosque.

I feel [she wrote] a great relief on seeing your letters to my husband; he had really need of them and I cannot

- Madame de Vence to Mirabeau, June 9, r774. Copy in Mouttet, Mirabeau en Provence, Chapter v.

2 Madame de Vence to Mirabeau, June 12, I774. Copy in Mouttet, Mirabeau en Provence, v. 
describe to you the effect they produced upon him. Deign to encourage him in order to draw him from the physical and moral depression into which he has fallen. ... As to his conduct toward me, be persuaded that it has always been very kind and his actions excellent. I wish with all my heart that he had conducted himself as much to your satisfaction as he has to mine. . . . I close by begging you to be good enough to allow him to see an end to his sufferings. ${ }^{1}$

At the same time, Mirabeau wrote both to his uncle and to his father. ${ }^{2}$

The contrition of the countess was soon put to the test. The letter addressed by Mirabeau to young Gassaud had not found him in Paris. He received it only at Aix, where he probably first learned of the discovery of his crime. ${ }^{3}$ With his appearance in his father's house, the relations between Mirabeau and his wife became once more strained. The letter of Gassaud had been burned by Mirabeau before the eyes of his wife; the letter of the countess, acknowledging her guilt, was in the possession of Gassaud. The musketeer was defiant and the countess became insolent. It was probably at this time that Mirabeau struck his wife in answer to the retort that "his mother and sister were strumpets." 4 In his desire to avoid a scandal, Mirabeau even forgot his threat to annihilate the seducer of his wife and refused to be provoked to a duel. These are the inferences that seem to be justifiable from

1 Observations sur un libelle diffamatoire, 49, 50.

2 See the letter of the marquis to the countess, June 28,1774 .

$3 \mathrm{M}$. Mouttet suggests that the return of Gassaud was due to a warning from the countess. This is, of course, simply an assumption and it is just as possible that he knew nothing of the discovery of his infamous conduct until he reached home.

- Lettres originales de Mirabeau, iii., 355. 
passages in the Lettres de Vincennes and in a letter of Madame de Vence.

A man [runs the first passage], treated as a friend, had inflicted upon me the most cruel and worst of outrages, accompanied by infernal duplicity. A tender attachment bound me to his family. His father, upon his knees, begged of me the life of his unworthy son. His mother bathed my hands in her tears. I nearly died of shame in seeing these grey hairs at my feet. I pardoned; I pardoned without reserve and without afterthought. In vain, by insolent provocations, by a formal defiance, was the attempt made to force me to abandon my resolutions; I mastered my anger. I had the glory of humiliating vice solely by the superiority of honesty. My sword did not leave its scabbard and that of my vile aggressor fell from his hand. ${ }^{1}$

Mirabeau informed Madame de Vence of what had passed.

I admire you as much as I am sorry for you [she replied], and that is saying not a little. Your situation appears to me frightful in every respect, and were it not for the feeling of self-contentment that you ought to have, I should consider you still more unfortunate. But I regard it as a great consolation to have done the best possible and to have put the wrong entirely on the side of the persons of whom you have reason to complain. I may not justify the conduct of Madame de Mirabeau, and whatever interest I may take in her, I do not pretend in any way to excuse her faults; I would like even to make her comprehend them. I hope that you will be or that you might be a little more content with her conduct toward you, but as that is not possible, it is necessary to expect everything from your good actions; it is not possible that they will not finally produce the effect they should produce upon

1 Lettres originales de Mirabeau, i., 339, 340. 


\section{Two Affairs of Honour}

a sensible and honest soul. I should regret very much not to regard Madame de Mirabeau as such. The horrible conduct of $M$. de Gassaud will certainly make an impression upon her and I am persuaded that she will see him in the future only with horror. I should be very sorry to believe that she has awaited this last conviction to make the distinction that she should between your two courses. I am sure that she felt it from the very first moment. I can attribute the remark that she addressed to you only to a moment of delirium. Be wiser than she for her interest and for your own and do not belie by a moment of cruelty such a long course of good conduct; I assure you that it has very much augmented the good opinion that I had of you. ${ }^{1}$

The affair was not, however, definitely arranged. "There was need," M. Mouttet asserts, "of the intervention of the parents and of the uncle, whose property the musketeer expected to inherit, to bring about a final agreement in virtue of which the portrait and the letters were returned to Mirabeau." 2 The secret was safe.

What must have been the feelings of the man, who had just passed through such an ordeal and had treated his wife with such generosity, what must have been his feelings on reading his father's answer to the letter written by the countess on the I 4 th of June, in which he finds no promise of immediate relief from his distressing financial situation and in which his wife receives marks of affection that the marquis, ignorant of her sin, continued for years to shower upon her! The letter was of the 28 th of June, I774, and must have

1 Madame de Vence to Mirabeau, June 26, I774. Original in the Minto collection in the possession of M. de Montigny.

2 Mouttet, Mirabeau en Provence, Chapter v. 
reached Manosque the first week in July. After acknowledging the receipt of the two letters of June $\mathrm{r}_{4} \mathrm{th}$, the marquis added that he would not reply to his son, as they had no need of duplicates.

Furthermore, my brother, who has also received a letter from him, will answer him, without doubt, and that is sufficient. My brother has not, as I have, given from a very limited fortune 8500 livres in annuity to have in addition and as recompense, a very heavy burden. [By way of interpretation, it should be remembered here that the bailli was sending his brother 15,ooo livres a year and that Mirabeau never received 8500 livres a year from his father.] My brother has not cared for and stood sponsor for a child all his life to see himself, at an age when one has a right to expect assistance from him, obliged to undergo for him an apprenticeship in the most cruel matters; my brother not having had a particle of all this, is not nailed and lacerated by consultations; by disagreeable scenes, by delays, by miscalculations, by obligations against everybody; my brother does not receive, by every courier, letters of accomplices, or of victims, of miserable beings that have been ruined, of others expatriated because they had given their indorsement, all complaining, invoking my aid, protesting that they will bring their children to my door, etc. ; my brother not having been intrusted with the maintenance of the paternal house, has not, as I have, sweated and grown old in the effort to conserve it; my brother, having a more steadfast soul and a keener sense of justice than I, had no need, as I had, from youth up, to form the habit of examining himself each day before God and man for fear of having been guilty of some injustice of commission or of omission. . . . Finding myself to-day in charge of a rigorous guardianship, I cannot help groaning and trembling before Providence. From all that, it follows, my dear daughter, that the dispositions of $m y$ brother are and always will be infinitely more proper to the 


\section{Two Affairs of Honour}

consolation with which you are occupied than my own. I no longer am able to appreciate the wrong that is done to me. Thus I pray God with all my heart to turn aside the bitterness of my old age from the head that has brought it upon me. I am willing to see only the wildness of the past, I am willing even to see hope in the future; but it is impossible at my age to reform the natural distaste, and worse than that, which I have for certain actions and their consequences.

It is not for me to put your husband again on his feet; it is for him to raise himself. Do not fear the revolution that you see in him; we ought, on the contrary, to desire it; without a physical revolution he will never become modest, patient, and distrustful of himself. If he does not change, it were better for him to die; if he does change, he may become a man of merit, and cause the wildness of his youth to be forgotten, by never forgetting it himself. But I repeat, to do that, a physical change will be necessary, and we have not yet reached that, by a good deal. I do not think, nevertheless, that your request of a limit to his sufferings can come from him, God preserve me from it! My daughter, get him to confide to you a statement of his debts, I know of nothing else from which he suffers. Now, as according to the course of nature I cannot see the end of them, I do not know how to prescribe it.

Finally, let him seek and labour himself to clear up and straighten out this mass; let him watch the course of his affairs; I will not conceal from him, at the close of each year, the details; let him think of himself as if he were a well-behaved son whom a profligate father had left loaded with debts. ${ }^{1}$

A few days after the receipt of this letter, probably as the result of the trying scenes through which she had passed, Madame de Mirabeau became critically ill and the premature birth that followed put an end to a

1 Letter given in Loménie, iii., I I8, I I 9. 
somewhat complicated situation. ${ }^{1}$ The sickness of his wife increased the expenses of the household and Mirabeau endeavoured through the mediation of Madame de Vence to obtain some financial aid from his father. "I have executed you commission to $M$. du Bourguet," she wrote, "and he acknowledged the justice of your request and promised me to write to your father that he had taken it upon himself to fix the commencement of your allowance for April I; I told him that that was not sufficient and that you needed money. He assured me that he did not have a sou and that he was going to tell your father that he was obliged to borrow the money to pay your living expenses." 2 At this time, when Mirabeau was not receiving from his father sufficient to live upon, his father had a house in Paris, a summer house at Bignon, and a chateau at Hyères.

But the affairs of Mirabeau were to be rendered still more complicated by his own thoughtless and passionate, although well-intended, acts arising out of the course of conduct that he had chosen to follow toward his wife and Gassaud, and his indignation at an insult to his sister, Mme. de Cabris. For some time, Mirabeau' had been engaged in negotiating a marriage between M. de Gassaud and Mlle. de Tourettes. The affair

1 Between the 8 th and the $\mathrm{r}_{3}$ th of July, $\mathrm{I}_{774}$, according to the letters of Madame de Vence addressed to Mirabeau. In his Observations pour le Comte de Mirabeau ( ${ }_{7} 78_{3}, \mathrm{p}$. I), Mirabeau wrote: "En r774 les symptômes d'une nouvelle grossesse disparurent au milieu d'un rhume violent.". In the Lettres originales de Mirabeau (iii., 352) is a letter to Dupont de Nemours in which Mirabeau refers to this affair as follows: "Ainsi donc me déshonorer dans la bête d'acception que l'on donne à ce mot, et, ce qui est plus sérieux, me donner un enfant qui n'était pas à moi, et dont une fausse couche l'a délivrée."

2 Madame de Vence to Mirabeau, July r $_{3}$, I $_{74}$. 


\section{Two Affairs of Honour}

seemed about to take an unfavourable turn, possibly due to the rumours of his relations with the countess, and Mirabeau, fearful that the reputation of his wife might be compromised, violating the orders of the king that exiled him to Manosque, mounted his horse and rode a hundred miles across country to render a service at the same time to Gassaud and to himself. "The future father-in-law," he explained at a later time to his father, "was my friend. The idea that the family of the young man might suspect me of having alienated him, broke my heart. I mounted my horse; I galloped to Tourettes. I urged, I plead, I conjured. The negotiations were renewed and they were successful." 1

Had he at once returned to Manosque, his absence might never have been noticed, but Tourettes was near Grasse, the home of his sister, and it was part of the purpose of his journey to call upon her and to avenge an insult that had been inflicted upon her. It is necessary at this point to become better acquainted with this bizarre character that we have already encountered and whose influence upon Mirabeau's life will continue to make itself felt for some years to come.

Louise de Riqueti was the youngest daughter of the Marquis de Mirabeau. Like her sisters, she received her early education in the Benedictine convent at Montargis. At thirteen years of age, she was placed as a boarder in the Dominican convent of the same city, where she remained until her seventeenth year, leaving it only a few months before her marriage. According to Mirabeau, "the charming thing about this convent was that it was not at all religious; that several ladies had retired there for the pleasures of society; that

1 Lettres originales de Mirabeau, i., 340. 
there was company the year round; that one learned the usages of society and not the awkwardness that one acquires elsewhere behind the convent grate; that there are masters of all kinds." Mlle. Louise was intrusted to the charge of Mme. de Remigny, "a frivolous woman, comprehending and practising the life of the convent in the least severe manner in the world." During the time that she was there and the short time that she passed at home, the marquis, prejudiced by the reports of Mme. de Remigny, was enthusiastic in his praise of the child. When she was only thirteen, he characterised her as "a rare child both in mind and temperament, a charming character"; at fifteen, she was, "in mind and judgment, the rarest subject of her day." It was at about this time that her hand was sought by young D'Orsay, the step-son of Lefranc de Pompignan, an intimate friend of the marquis. D'Orsay had seen the young girl in the parlour of the convent and had fallen in love with her. He was wealthy, having an income of 300,000 livres, but he was the son of a fermiergéneral. To the overtures that were made to her, Louise replied: "I will never change my name for a worse; I am ignorant of what one does with riches, but if they are necessary, I feel that I possess the talent to attract them to the house that I enter." The marquis reported these words with delight.

The relations between the marquis and his wife, that might at any time produce an open rupture and render it difficult to marry his daughter suitably, led him to accept the first suitor proposed by the bailli, whose birth and wealth rendered him eligible. This person was the Marquis de Cabris, a young man of nineteen. There were cases of mental alienation in his family and the marquis was informed of it, but he was determined 


\section{Two Affairs of Honour}

to conclude the arrangements. Mme. de Pailly, furthermore, whom on this and other occasions he called-employing the expression of one of his friends - the "father prefect" of his house, desired the marriage and concerned herself with it, he said, more than he himself. The marriage contract, in which Louise did not obtain from her maternal grandmother the same advantages that her sister, Mme. du Saillant, had received-a cause of subsequent jealousy-was hurriedly drawn up. The Cabris family proposed that a meeting between the young people should be arranged before deciding on the union, but the marquis rejected the idea. "My daughter," he replied, "will not take a journey to meet a husband. They have only to inform themselves as to what she looks like, and it is my opinion that the conjugal amalgam, as far as the physical form is concerned, is not a difficult thing at twenty years, when those united are not prejudiced. . . . My daughter," he wrote a little later, "will leave the convent only to be married in the church there, or, at any rate, at Bignon, which is only four leagues from there." And this was the man whose whole life had been wrecked by a mariage de convenance!

In the summer of 1769 the young girl was taken to Bignon, and on the r8th of November a carriageful of Provençals arrived at the chateau under the guidance of the bailli. The first sight of young Cabris, gloomy and distrait, astonished the marquis and did not fill his daughter with much enthusiasm. Her father noticed during the two days that the young people were together that Louise "bit her nails when he came near her to pick up a book." The marquis was not, however, disturbed by this, for he had a theory that "if the thing was to last, it should not begin too vigorously." On 
the contrary, after the arrival of the party, the marriage was celebrated; on the following day "the marquis gave his benediction and the party, augmented by the bride, set out for Provence." 1

What kind of a person was this young girl, sacrificed in so brutal a manner by her father? Mirabeau has drawn a picture of her in his letters written from Vincennes. "With all the spendour of a most brilliant youth, she had," he wrote, "the most eloquent black eyes, the freshness of Hebe, that nobility that one sees no longer except in ancient statues, and a figure more beautiful than any other that I have ever seen; who had, I say, with all this, that suppleness, that grace, that magic of seduction that pertains only to her sex." $\mathrm{He}$ asserted, furthermore, that she possessed

an intelligence of an extent and keenness seldom found even among men the most distinguished for their talents. I do not doubt that a man of honour and judgment, in love with her, would have been able to restrain her mind and set her heart right; for her imagination is really the unique theatre of her opinions, of her sentiments, and perhaps, also, of her sensations; but her impetuosity, her nobility, her fecundity, at that time, wasted their resources. This astonishing woman was susceptible of generosity through amour propre, of sensibility through illusion, of constancy, of fidelity even, through stubbornness. ${ }^{2}$

This was Mirabeau's opinion of his sister when he was no longer prejudiced in her favour; it was his conception of what she might have become, had she married the right man. What she did become, he related elsewhere in the same letters. Madame de Cabris

1 The data given above concerning Madame de Cabris I have taken from M. Charles de Loménie, iii., r20-r30.

2 Lettres originales de Mirabeau, iii, 289, 299. 
had a lover "fifteen days after her arrival at Grasse," the residence of her husband.

My uncle talked to her about it, more as a prudent and tender uncle, who felt that the happiness of her whole life might depend upon this step, than as an austere casuist. Cabris was a libertine; his wife, like all unfaithful women, displayed an extreme jealousy; my uncle attempted to moderate her passion. All his lessons were so badly received that he soon wearied of his self-imposed task of watching over the debut of his niece at Grasse and returned to Mirabeau; that did not prevent him, at the time of the journey that she took some months later to meet me, to show the greatest tenderness toward her. ${ }^{1}$

In this last sentence, Mirabeau refers to his meeting with his sister in Aix, on his return from Corsica, in I770. They were much devoted to one another at this time and the presence of Louise, according to the bailli, interfered with Mirabeau's economic studies. ${ }^{2}$ Madame de Cabris became the confidante of the amours of her brother and his assiduous correspondent. ${ }^{3}$ In I 772 she was present at his wedding, and her name appears among the witnesses to the marriage contract. There is no evidence that Mirabeau saw his sister again until he met her in Grasse on his return from Tourettes, in response to her letter.

Shortly before the visit of Mirabeau to Grasse, Madame de Cabris had become involved in an affair that raised against her and her husband the entire society

1 Lettres originales de Mirabeau iv., 133, I34.

2 Correspondance générale, vi., 375. The bailli to the marquis, Aix, August 23, 1770: "Peut-être le trouveras-tu pas bien fort dans le métier d'économiste. Il y aurait mordu comme un autre, mais sa scur, qui est ici, lui ôtait beaucoup du temps qu'il était accoutumé de donner au travail."

3 Loménie, iii., I3I. 
of the place. During the winter of 1773 and 1774 , the home of the lieutenant-géneral of the sénéchaussée of Grasse had been the centre of the social life of the city. Among the guests were $M$. and Mme. de Cabris. Suddenly they absented themselves from the gatherings; a coldness had sprung up; sharp expressions were exchanged, followed soon by something more serious. On the morning of March I6, I774, the inhabitants of Grasse awoke to find affixed to the doors of the houses of the most distinguished people in the place a diatribe in sixteen couplets in which the whole society that assembled at the lieutenant-generral's was insulted in the most shameful fashion. The lines were indecent beyond description. Copies were scattered in the churches, in the shops, and in the public places. All Provence was inundated with them.

Mme. de Cabris was suspected, but without just cause. The verses were written by a procureur in the service of $M$. de Cabris, the baron himself, in a condition verging on imbecility, being incapable of producing even such miserable doggerel. It was shown, however, in the investigation that followed, that he had assisted, during the night, in placarding the town. During the investigation, society was divided into two groups, very bitter toward each other. $M$. de Villeneuve de Mouans, a relative of the Cabris, attempted to reconcile the two parties, so he states, and to put an end to the scandal.

But [he explained] in accordance with the principles of justice that animated him, he had not hesitated to say, to some persons who had spoken to him of this affair, that a reparation was necessary, proportional to the nature and publicity of the outrage. Unfortunately, Mme. de Cabris was connected with one of the suspected persons. She 


\section{Two Affairs of Honour}

was offended by the acts and by the remarks of $M$. de Villeneuve; she was more irritated still on learning that he had written that he and his wife had reason to complain of her conduct toward them, but they intended to avenge themselves by good offices. ${ }^{1}$

Whether this is the exact truth or not, it is impossible to tell. According to M. de Montigny, Mirabeau asserted that his sister had been "grievously insulted by M. de Villeneuve on the streets of Grasse." 2 At any rate, his sister had complained to him of the action of M. de Villeneuve and when Mirabeau left Manosque, he intended to have a meeting with this gentleman. ${ }^{3}$

Mirabeau reached Grasse on the 4 th of August. The next morning, accompanied by his sister, in male attire, and a M. de Briançon, a lover of Mme. de Cabris, he set out on horseback for the country-seat of Mme. de la Tour-Roumoulles, a sister-in-law of M. de Villeneuve and his sworn enemy. The Pavillon des Indes, as the residence of Madame de la Tour-Roumoulles was called, is some two leagues from Grasse. It is situated in the midst of olive trees on the side of a hill, overlooking the villages of Mouans and Sartoux. The property touched the estate of M. de Villeneuve, Baron de Mouans.

At four o'clock in the afternoon, M. de Villeneuve

1 Joly, M. A., Les procès de Mirabeau en Provence (Paris, 1863 ). This work is based upon the records of the trial preserved at Grasse. I have, also, made use of Loménie, iii., $\mathrm{r}_{3} \mathrm{I}-\mathrm{r} 38$.

2 Montigny, Mémoires de Mirabeau, ii., 33.

3 Correspondance générale, $\mathrm{x} ., 234$. The bailli to the marquis, Aix, February 25, 1782: "Il est certain que Rongelime [Mme. de Cabris] avait appelé son frère. Un homme digne de foi a vu la lettre qu'elle lui écrivait à ce sujet."-Quoted by Guibal, i., I3 I, note r. Lettres originales de Mirabeau, i., 340: "La rencontre de Villeneuve fut une vraie rencontre où il n'entra aucune prémeditation, quoiqu'il fut bien dans mes projets de lui faire une visite."

vol. $1-28$ 
was in his fields directing the labour of his workmen. The party from the Pavillon, having just dined, were enjoying a stroll in the open air. Mirabeau saw the man that he had come to Grasse to interview and hastened toward him. Words were exchanged and Mirabeau, seizing the sun-umbrella that the baron carried in his hand, beat him with it until it broke in : pieces. Thereupon he seized $M$. de Villeneuve and shook him violently, and when his opponent grappled him in self-protection they rolled together down a low bank near which they were struggling. Mirabeau had fallen uppermost and continued to attack his victim, "raining blows upon his face and elsewhere," to use the language of the complainant. Madame de la Tour-Roumoulles, Madame de Cabris, and M. de Briançon stood by, laughing heartily. A peasant woman, washing linen in a neighbouring fountain, had observed the affair and ran to the spot. Prevented by Mirabeau's companions from interfering in behalf of her master, by her loud cries she attracted the attention of some labourers, who hurried to the aid of the baron. Then Mirabeau desisted and retired with his companions, first throwing some silver to the peasants, saying, "To prove to you that I am an honest man, here go drink to my health."

Not a very serious matter, it would seem, and yet on the 9th of August, I 774, M. de Villeneuve entered against Mirabeau the complaint of attempted assassination. A more amusing document than that containing the charge it would probably be difficult to find in the records of criminal trials. According to M. de Villeneuve, the peasants "raised the unhappy victim and bore him back to his chateau, his countenance covered with blood and his body bruised with the blows that 
he had received. On account of the vigour of his constitution, M. de Villeneuve did not realise at first the extent of his injuries, but the first fermentation of his blood having passed, he finds himself to-day in a state of weakness, that gives cause for anxiety."

It resulted from the testimony of the witnesses at the trial that a surgeon who had been called discovered nothing but a few scratches and that "the unhappy victim," instead of being carried back to his chateau, instructed his peasants to return to their labours, and walked off to another part of his estate.

The attempt to prosecute the case encountered many obstacles and offers an interesting illustration of the manner in which justice was administered under the ancient régime. No judges could be found at Grasse. "Carpillet, lieutenant-criminel,'was occupied '; De Floris, lieutenant-civil, was sick; called one after the other, as their names appeared on the roll, the advocates imitated the judges," giving various reasons for their refusal. Finally an advocate was found, a M. Raphael Albanelly, who was willing to take the testimony. During four days, August I0, II, I3, and I4, I 774, he listened to witnesses. The identity of the accused was not doubtful. All the witnesses described a man "rather tall and stout, very much marked with smallpox, wearing a suit of blue silk, with blonde hair unpowdered, tied behind in the form of a cadogan." Nor was there any uncertainty about the facts. On August r8th, all the witnesses having been heard, Albanelly decided that the matter "should be laid before the procureur of the king."

To find a prosecuting officer proved as difficult a matter as to find a judge. The records bear witness to thirteen refusals, all furnishing more or less amusing 
excuses for their action. At length, M. Laugier, the oldest advocate on the list, undertook to fill the office of procureur, and in accordance with his conclusions Albanelly on August 22 decided "that Mirabeau should be taken and bodily seized and conducted to the prison of Grasse, to be heard and interrogated, and if he could not be taken, perquisitions should be made, the affair should be made public by the crier, and his goods should be seized and listed; that the M. de Verdaches, Coseigneur de Briançon, should be summoned to appear in person; the ladies De Cabris and De la Tour, assigned to be heard in person."

Mirabeau was no longer in Grasse, having taken his departure for Manosque on August i 7 th. The affair in itself was not serious, nor was the action of $M$. de Villeneuve in appealing to the courts looked upon with favour even by his own relatives. A gentleman in those days was supposed to defend his honour with his sword.

You know [wrote Mirabeau to his father from Vincennes] that the Villeneuves were the first to praise my conduct and to cover with infamy that of their relative. You know that the old marquis, who had become, in a certain sense, the head of the house, wrote to me: "Be assured, M. le Comte, that I shall always put an infinite distance between a friend who conducts himself as well as you on important occasions, and a relative who dishonours his name, if the shame be not personal." You know that the count, who had become his son, made the same bitter reproaches to his cousin and laboured in my behalf at Grasse. You know that Madame la Comtesse de Vence, a woman universally respected, was my advocate and my counsel in this affair, and the Marquis de Tourettes, who bears the name and the arms of Villeneuve and enjoys the esteem of 


\section{Two Affairs of Honour}

the entire province, wished to be my procureur in this procedure. ${ }^{1}$

Mirabeau also claimed that $M$. de Marignane wrote to him that the "best document that could appear in his defence was the complaint itself of $M$. de Villeneuve."2

But Mirabeau was an enemy of the Maupeou parliament at Aix and the case came within its jurisdiction. The members of the parliament were not likely to overlook the fact that in leaving Manosque without permission Mirabeau had violated the orders of the king that exiled him to that place and would make as much as possible of the scandal produced by the affair at Grasse. "The procureur-general of the court wrote to the chancellor a letter concerning Mirabeau that deserves rather the name of réquisitoire." 3 Even if the lettre de cachet of the King prevented the parliament from executing the order for his arrest, the trial could continue at Grasse. "It would be very difficult," wrote M. de Marignane to Mirabeau on August 24, I 774, "for justice or for the government not to pronounce some punishment; it would be, perhaps, advantageous that the last should help you to avoid the condemnation of the first, which will always be more rigorous." 4 Mirabeau had evidently reached this conclusion before receiving the letter of his father-in-law, for he had despatched his wife to Bignon to lay the affair before his father, in a favourable light, and to secure his intervention.

In spite of her condition-she had not fully recovered

1 Lettres originales de Mirabeau, i., 337.

2 Ibid.

s Guibal, i., I33.

4 Loménie, iii., 137 . 
from her sickness-the countess set out, accompanied by a valet and a femme de chambre. Her father was alarmed at the journey, but did nothing to render it easier for her. At Aix, she knocked at all doors, without finding anyone who would lend her a carriage. An intimate friend of her father, M. de Valbelle, who was then at Tourvès, had a carriage in the city and the Marquise de Marignane despatched a messenger to him requesting the loan of it; the request was refused. Madame de Mirabeau was finally obliged to hire a carriage of the Jew Rodolphe, who charged her thirty écus for the use of it. ${ }^{1}$

"At last, I am about to depart, my dear," she wrote to her husband from Aix on August 23d. "Don't scold me, for yesterday I passed the saddest day that I have ever had. . . . I miss you more every day." 2 While in Aix, creditors had besieged her door, and as her carriage passed down the main avenue of the city, one had the presumption to present himself at the window and urge his claims. ${ }^{3}$

The journey was a trying one and the comtesse experienced many disagreeable things from postillions and suffered much from stormy weather. Thunder and rain forced her to remain for some hours at Avignon and later at Tain. At midnight, August 24th, she reached Lyons. Here she remained but a day, seeing little of the city, and set out on the evening of the $25^{\text {th }}$ for Montargis.4 "I am sad, my dear," she wrote to her husband. "I am already weary of seeing people that I do not know and who take no interest in me. I am still almost on the borders of Provence and I am home-sick already for it, at least for the

1 Guibal, i., 133 .

- Observations pour le Comte de Mirabeau, 2.

- Guibal, i., I34.

- Ibid. 
place where you are. God grant that we may meet again soon, for we were not made to be separated."1

Mirabeau endeavoured to prepare the way for the countess by writing to his sister, Madame du Saillant. "I am sending you a sister," he announced to her August 2oth. "Be her counsel, her guide and her friend in the most serious affair I have ever had in my life. Care for her health, as she will care for yours, and both of you have a care for that of my father, of whose illness I had not heard."2 Although ill at the time, Madame du Saillant set out at five o'clock on the morning of August 3 oth to meet the countess at Montargis, where she had been in a convent since the previous evening, and to bring her to Bignon.

At Bignon, Madame de Mirabeau found all the Du Saillants, the bailli, and Madame de Pailly. The marquis was absent and knew nothing yet of the fresh escapade of his son. He returned to Bignon on September 2. Madame du Saillant went to meet him in order to warn him, for fear of a revolution. His daughter-in-law trembled at the idea of appearing before him; he received her kindly, but informed her that he was too agitated to talk that evening about the affair of his son. The next day, he broached the subject with an irritation upon which all the arguments of Madame de Mirabeau could make no impression. ${ }^{3}$

"He proposed to me," she wrote to Mirabeau on the same day, "that I should remain here as long as this thing lasts. Knowing your intentions in the matter I did not refuse; but you know, my dear, that I am always very much disposed to follow you, or to go to

1 Observations pour le Comte de Mirabeau, 3.

2 Guibal, i., 134.

s Ibid., i., I33. 
find you in whatever place you may be, and with great joy, I assure you." 1

The marquis gave his daughter-in-law little opportunity to plead the cause of her husband; the letter addressed to the Duc de la Vrillière asking that Mirabeau be arrested and transferred to the Chateau d'If was written at Bignon, September 2, 1774, the night of her arrival. When the countess presented her case to the marquis the next morning it was already too late. He had acted simply on the information received from Madame du Saillant. "My son," ran the letter to the minister, "has violated his order of exile and has left the place where he was retained by the command of the king. He has added to this extravagance, that of an ugly affair of the most scandalous kind. In the character of his first judge, I believe that I ought to request his punishment. I pray you, then, to be good enough to obtain an order of the king that he may be imprisoned and retained in the Chateau d'If. I beg you to pardon my importunities and be good enough to have compassion on a father so unfortunate as to be obliged to solicit favours of this kind."2 There was little need for such harshness and such haste on the part of the marquis. He had no reason to be disturbed at the attitude of the parliament of Aix.

Maupeou had just been exiled. The days of the parliaments that he had founded were numbered. The reaction that had already taken place, and that ought to become even more marked, could only be favourable to the Comte de Mirabeau. The economisme was about to reach the height of its grandeur. Nothing would have been more easy for the marquis than to protect his son. The misdemeanour

1 Observations pour le Comte de Mirabeau, 4

2 Archives nationales, K, I64, No. 2, 15. 
of the latter was not very grave. . . . At Bignon all were, in fact, well disposed toward Mirabeau; they poured out their anger upon Madame de Cabris, "a beggar," said the bailli, "that ought to be crushed between two stones." 1

Meanwhile, the countess was ignorant of what the marquis was about. At least in the letters to Mirabeau she kept up a hopeful tone and revealed no knowledge of the real situation. "My father-in-law," she wrote on September 6, I774, "cited to me the other day among the reasons that he gave for remaining with him, the necessity of being your advocate. That pleased me. He never complains of your head without eulogising your heart. Finally he showers kindnesses upon me; and it is certain that one would not treat thus the wife of a son for whom one did not wish to do anything." She referred to a plan to send to Provence for her son and hints that if they both conducted themselves well Provence would play little part in their future. She continued to assure him of her devotion. "In spite of all the kind treatment that I receive here," she wrote, "I do not feel at home; I cannot prevent myself from thinking that I am a stranger here, without heart-ties. So that I seek constantly, without ever finding." 2

On September 7, I 774, the order was despatched to arrest Mirabeau and take him to the Chateau d'If. ${ }^{3}$ On the same day a letter was sent to M. Joannis at Aix requesting him to put an end to the prosecution of

1 Loménie, iii., I4 I; Guibal, i., 135, 136.

2 Observations pour le Comte de Mirabeau, 5 .

3 Archives nationales, $K, 164$, No. 2, the receipt of Senac de Meilhan. The order for Mirabeau's arrest is found in the Archives des Bouches-du-Rhone and has been published in the Revue rétrospective (1889), 249. 
Mirabeau at Grasse. The procureur wrote at once to M. de Villeneuve requesting him to drop the affair. "I am very desirous of succeeding in this matter," wrote M. de Joannis to the minister, "and of showing this family [the Riqueti] all that I would like to do for them." 1 His zeal may have been due to the rise of the influence of the Physiocrats in the government. In the letter ordering the arrest of Mirabeau, the Duc de la Vrillière remarks that in leaving his place of exile "he had rendered himself guilty of a disobedience that his Majesty did not believe that he could leave unpunished." The duke informed the intendant that the expenses of arresting Mirabeau and conducting him to the chateau were to be paid by the marquis. The $5_{5}$ th of September, Senac de Meilhan issued two orders to M. Ouvrière, officer of the marechaussée, one for the officer himself, instructing him to arrest Mirabeau and conduct him to the Chateau d'If, the other for the commandant of the Chateau, M. d'Allégre, authorising him to receive and retain the prisoner. ${ }^{2}$ The orders were executed at once, $M$. Ouvrière being assisted by two cavalrymen. "Mirabeau had, for a moment, the

2 Archives nationales, K, 164, No. 2, 23: "J'ai cru apercevoir." wrote Joannis, "dans votre lettre du 7 septembre, au sujet de la détention du comte de Mirabeau au Château d'If, que vous croyez que les poursuites de la justice devraient cesser." On the 29 th of August, Joannis had written to La Vrillière an account of the affair at Grasse. This letter could not have reached Versailles before the letter of the marquis asking for the imprisonment of his son. This conflicts with the statement of the countess that the government was informed of the affair before hearing from the marquis. The letter of Joannis is found in the Archives nationales (K, I64, No. 2, 14); the letter of the countess is given in Loménie (iii., I $40,14 \mathrm{I}$ ).

2 The receipt of the two officers of the marechaussée is found in the Revue rétrospective (1889), 249; the receipt of the commandant is in the Archives nationales, K, I64, No. 2, I9. 


\section{Two Affairs of Honour}

thought of evading the arrest with which he was threatened, and of hiding himself for a few weeks; then he disdained this expedient and awaited the officers at Mirabeau."1 On September 2oth he was taken down the harbour of Marseilles and landed upon the lonely rock crowned by the Chateau d'If, rendered famous by Dumas in his tale of Monte Cristo. The expense of the arrest, paid by the marquis, amounted to 403 livres, Io sols. In sending the account to $\mathrm{La}$ Vrillière, De Meilhan apologised for the size of the bill, explaining that "it should be considered that there were fifteen good strong leagues, that the officer and the two horsemen that he employed were obliged to be on foot a whole day in order to execute the order." He added, "I would not have been willing to intrust it to anyone but M. Ouvrière, with whose intelligence and firmness I was acquainted."2

This imprisonment could have been no surprise to Mirabeau. He had warned his wife, in his first letter to her after her departure, "not to be frightened at a few months in a citadel." 3 He acknowledged to his father, while at Vincennes, that as he had left his place of exile without permission the marquis would have had trouble in excusing his conduct to the minister when this irregularity had led to a scandal, meaning the affair at Grasse. ${ }^{4}$ He did not think, however-and he was right in thinking as he did-that his father had done all he could to plead his cause with the minister.

1 Guibal (i., I37): "Tu me disais, dans ta dernière lettre, que tu comptais te cacher 15 jours. Je suis bien en peine de savoir comment tu auras exécuté ce projet." - Letter of the countess to Mirabeau, September 26, I 774 .

2 Archives nationales, K, I64, No. 2, 2 I.

3 Observations pour le Comte de Mirabeau, 7.

- Lettres originales de Mirabeau, i., 34r. 
"I cannot believe," he said, "that you made a travesty of it to the minister. Twenty persons have told me so; again, I do not believe it. The most implacable, the blackest, the most perfidious enemy could hardly be capable of such a course." 1

The news of the arrest and the manner in which it had been executed produced an indignant protest at Bignon. The countess was much moved and the marquis passed the day consoling her, "kissing her the whole day long, from the roots of her hair to the tip of her chin." He assured her that her husband would be materially well off at the Chateau d'If. ${ }^{2}$ But Madame de Mirabeau knew on the thirteenth of the month what the fate of her husband was to be. On that day, she wrote to him, assuring him that she had done all that she could, but

all my efforts [she added] have been useless, my dear one, and I have not been able to save you from the blow that crushes me. Your uncle and your father have assured me that it was not in their power to prevent the government from punishing you for breaking your ban and they have acquired, at least your father, by their demand, so much more right to withdraw you from it. Your father always appears very choleric toward you; I believe it is that he may anticipate my importunities. You may easily believe that that will not relieve him from them. I am in a state of profound sadness since I have learned that the ministers have despatched the order; for it did not pass by way of this place and they were even instructed of the decree [at Grasse for the arrest of Mirabeau] when my father-in-law wrote to them. I never cease to think of you and of the frightful state to which this order will consign you. The

1 Lettres originales de Mirabeau, i., 339.

2 Guibal, i., $\times 37$. 
tears stream from my eyes when I am alone or when you are mentioned.

She promises again to come to him, if he desires it. When she had suggested to the marquis the idea of following her husband, he had informed her that "it would not be decent." She had been told that prisoners of state were not permitted to receive letters, but permission had been asked that she might correspond with her husband. "My father-in-law asked me to promise that I would not send letters from anybody else, but I refused point blank, saying that I could not keep it, as I did not wish to refuse you anything." 1

The marquis appears to have played a double rôle. His treatment of Mirabeau would be difficult to explain on the ground that he simply wished to shield him from punishment. He was directly responsible for the rigorous treatment of his son. We learn from a letter of the commandant to the minister ${ }^{2}$ that the marquis had furnished that officer "with such information as was necessary to acquaint him with the dangerous character of his son, and had sent him at the same time the imprint of the seal of the countess." The commandant was so impressed with the dangerous character of his prisoner that, learning that Mirabeau was about to ask the freedom of the place through the countess, he requested that his petition be not granted as it would interfere with the strict surveillance that was necessary. "Enterprising as he is," remarked M. d'Allégre, "he would nullify all the measures that I might take to conform exactly with the orders of your highness."

1 Observations pour le Comte de Mirabeau, 5, 6; Loménie, iii., 140.

2 Archives nationales, K, I64, No. 2, 20. 
For the fourth time, Mirabeau was the victim of a lettre de cachet, for the second time he was the occupant of a state's prison. Up to the present, he had suffered from the arbitrary power placed in the hands of his father by the old family organisation; he was now to feel the weight of governmental oppression placed at the disposal of his father. Here were sufficient reasons to make of him an opponent of arbitrary power, but his interest in the great question that was stirring France to its depths was not consciously due to his own sufferings. The interest that he took in the affair between the ministry and the parliaments has already been shown, and it is little surprising that a man of his early maturity, of his experience, of his sympathies, of his intellectual connections, should be desirous of adding to the literature of opposition that never ceased to come from the press during the last four years of the reign of Louis XV. and of the existence of the Maupeou parliaments. When the door of Chateau d'If closed upon him, Mirabeau's first contribution to the great debate that was to terminate with a constitution for France, his Essai sur le despotisme, had been written. 


\section{CHAPTER XVI}

\section{THE "ESSAY UPON DESPOTISM"}

$\mathrm{N}$ the winter of $\mathrm{I773}$, the success of Maupeou's coup d'état seemed to be assured and arbitrary government was triumphant in France. ${ }^{1}$ It was at this time that Mirabeau wrote his Essay upon Despotism, as a protest against the despotic course of the government and as an appeal to the French people and to their ruler. It was no mere literary exercise, but a political document. "It was prepared in haste," wrote Mirabeau, "because I wished to take advantage of the crisis into which France had been plunged to produce a sensation that I believed possible and necessary." 2 It was about to appear when Louis $\mathrm{XV}$. died. The times changed, and "to publish such a writing, it was necessary to wait until the evil days returned." That the book did not at once see the light matters little; the fact that it was written to pro-

1" On a vu qu' à la mort de Louis XV. le nouveau parlement de Paris, un instanté branlé par l'affaire Beaumarchais, avait repris consistance. L'agitation politique avait cessé depuis plus d'un an; il ne paraissait presque plus de libelles et les esprits si violemment surexcités en 177 I s'étaient apaisés; dans toute la France, la justice était administrée d'une façon régulière et normale. Il est incontestable que Maupeou avait réussi."-Flammermont, Le Chancelier Maupeou et les parlements, 592.

2 Unless otherwise indicated, all the quotations from the Essai sur le despotisme are from the first edition, bearing the imprint, Londres, 1775 . 
duce a political effect and owed its origin to a specific political situation makes the date significant in Mirabeau's life. From this time forth he never ceased to interest himself in public affairs and to take every opportunity to educate public opinion in the principles of government based upon law. From 1774 until 1789 , until the representatives of the nation triumphed over the king, Mirabeau was a vigorous opponent of arbitrary government. The Essai sur le despotisme was a veritable confession of faith to which he ever remained true.

It was probably written in the first three months of I774, during his exile at the chateau de Mirabeau, ${ }^{1}$

1 The biographers of Mirabeau disagree upon the place and date of the writing of the Essai. M. de Montigny states (Memoires de Mirabeau, iv., 4) "que ce fut pendant son exile à Manosque, à la fin de I772, que Mirabeau composa son premier ouvrage, l'Essai sur le despotisme." It could not have been 1772 if it was composed at Manosque, and it could not have been composed at Manosque if it was written in $\times 772$. The events of $\times 772$ and 1773 were seemingly confused by M. de Montigny. Professor Stern writes (i., ro3) of "le Traité sur le despotisme," composé peu de temps après la mort de Louis XV.," that is, at Manosque shortly after May ro, I774. According to M. Charles de Loménie (iii., I45)," au moment où Mirabeau fut arrêté à Manosque, il y achevait, pour se distraire de ses soucis de toute sorte, son premier ouvrage connu l'Essai sur le despotisme." That is, the work was written at Manosque, at least finished there.

There are good grounds for believing that it was written at Mirabeau in the first three months of r774. Mirabeau went to the chateau the last week in December, I 773, and left it for Manosque the second week in April, r 774. He remained, then, at Mirabeau about three months. From internal evidence, it is clear that the work was written either late in $\times 7.73$ or early in 1774 . See page $\times 77$, note $\mathrm{I}$, "En I 773, un arrêt du conceil " etc; I 80, note $r$, "Pourra-t-on effacer jamais des fastes de la France, qu'en I 773 , trois vaisseaux de guerre" etc.; I93, note 2, "Il n'y a que deux ans, que M. Gaillard, dans un discours de reception à l'Académie" (Gaillard was received in 1771$) ; 202$, note $x, a$ book is referred to with the date $x 773$ and the observation is made, "C'est à cette époque que l'Essai sur le 


\section{The "Essay upon Despotism"}

and was addressed to the dauphin, later Louis XVI. The form is poor, betraying no plan whatever. Mirabeau realised this, attributing it to the haste with which the work was composed. At the opening of the book, he states that his purpose is simply to bring together general reflections upon despotism, "an undertaking," he adds, "better suited to my mediocrity, for indignation gives colour." After laying down a few "first principles," he "abandoned himself to his ideas as they presented themselves to his imagination." M. de Montigny was convinced, "after a long and fruitless examination" that "in order to find a plan for the work

despotisme devait paraitre." On the other hand, it was evidently written under the influence of the coup d'état of Maupeou and before May Io, $\times 774$, the date of the death of Louis XV. It is filled with the spirit of opposition to arbitrary government and betrays no trace of the enthusiasm that marked the beginning of the reign of Louis XVI. See page 3: "L'ouvrage renfermé sous ce cachet allait paraître quand Louis XV. est mort. Il fut fait à la hâte, parceque je voulais saisir le moment de crise ou la France était plongé, pour produire une sensation que je croyais possible et nécessaire;" I 69, note, "L'on peut remarquer à ce sujet dans les gazettes récentes, qui détaillent la position des quartiers d'hiver des differentes troupes en Corse," evidently the winter of $1773^{-1774}$ and written in the winter; 9-13, the letter to the dauphin, clearly the young man who later became Louis XVI., would have had little point if written after the death of Louis XV. See the introduction to the third edition of the Essai, page xvi., where Mirabeau states that he was not more than twenty-three when he wrote the Essai "en trois mois," and pages xxxii.-xxxv., where he declares that it was written in less than three months, during an enforced exile "dans ses terres," that is, at Mirabeau. All the evidence, then, seems to point to Mirabeau as the place of writing. It is, furthermore, the most probable place of writing, for the chateau had a good library and, as the condition of the count was less desperate at this time than later at Manosque, he would be able to apply himself more successfully. The question of the date of writing is an important one, for if the book was not written until after the death of Louis XV., my treatment of it as one of the pamphlets called forth by the coup d'état of I77I is not sound.

voL. I $I-29$ 
it would be necessary to make one." 1 The material is drawn from a variety of sources, chiefly from the writings of Sallust and Tacitus. Horace, Cicero, Montaigne, Rousseau, Montesquieu, Ami des hommes, Racine, Massillon, Froissart, Commines, Hobbes, Hume, Gregory of Tours, Mably, the Capitularies, and the collections of Bouquet also supplied him with matter for quotations or for reflection.

Although Mirabeau refers but twice to the Ami des hommes, on almost every page it is possible to detect the intellectual influence of his father. The teachings of the Theorie de l'impôt and of the Ami des hommes are incorporated into the book almost in the very language of the marquis. ${ }^{2}$ Mirabeau also gives utterance to the hereditary attitude of his family toward the favoritism of the court and to the righteous indignation of the bailli toward the men of the pen who had taken posesession of the posts of honour under the monarchy. ${ }^{3}$ The essay of the son lacks, however, the reserve that characterises the hardiest passages in the writing of the father. Mirabeau belonged to the younger genera-

1 Montigny, Mémoires de Mirabeau, iv., 9

2 The importance of population, the evils of luxury and cupidity, the position of the king as the first servant of the state, the theory of a society based on common interests, these were ideas that Mirabeau had found in the writings of his father. A comparison between the ideas of the Essai and those contained in the writings of the marquis (see Chapter VI) will make clear the debt of Mirabeau to his father.

3 In a note to page I60, Mirabeau refers to an episode in the life of the bailli that has already been mentioned in the chapter devoted to him: " J'ai vu la lettre d'un célebre brouillon de nos jours, à qui l'on a la bonté de croire de l'esprit, et qui après avoir renversé la marine, écrivit à un des chefs de ce corps, en lui reocmmandant le maintien de l'harmonie entre l'épée et la plume, c'est-à-dire, la subordination absolue de celle-là à celle-ci: ce grand principe base de l'administration. . . . Cela ferait rire, si cela n'était pas infame." 


\section{The "Essay upon Despotism"}

tion and was less inclined to compromise with misrule. He gave free rein to his indignation and expressed himself in language that would have fallen naturally from the lips of Desmoulins or Danton. Finally, the narrative is frequently interrupted by appeals to the prince or appeals to his countrymen, in which the future orator reveals himself.

The language in which Mirabeau described despotism is that of the revolution. "It is not a form of government," he exclaimed, "it is the annihilation of every essential form of government; it is a condition contrary to nature. . . . Despotism is to monarchies what idleness is to individuals, that is to say, the father of all the vices." It is "the exclusive destination of a single man to employ all others, even at their own expense, for his sole benefit, or what he believes to be his benefit. In a word, a despotic state becomes a sort of menagerie, the chief of which is a wild beast, who has over those who surround him no other pre-eminence than this."

This "state contrary to nature" had been intro- 1 duced into nearly all the constitutions of Europe, degrading and transforming language, ideas, and even sentiments.

For centuries, efforts have been made to introduce it into France, where there have been employed sucessively, to this detestable end, secret but effective intrigues and finally violent but authentic means. The most beautiful country of Europe [he laments], France, our native land, this cherished daughter of nature, whose riches are inconceivable and whose resources are without number, displays the sad effects of absolute authority; the air that we breathe is no longer that of liberty. We may neither describe its woes nor deplore its situation; complaints even are forbidden; when the tutelary authority is despotic and 
menacing, liberty becomes license, truth is a crime, and courage a danger; we are no longer permitted either to talk or to listen. Informers surround us; and we would have lost memory with speech were it in the power of man to forget as well as to be silent.

The Europe of the olden time knew not this spirit of servitude that has later shown itself, "the spirit that has created certain knowledge, full power, and for such is my good pleasure-a sort of protocol," observes Mirabeau, "that will cause posterity to regard our style as that of baseness and servitude."

So deeply was he impressed with the evils of despotism that, were it necessary to choose, he would "prefer without hesitation a feeble and incomplete authority to an absolute power, to whatever hand it might be intrusted. A weak authority could not furnish, without doubt, a happy and prosperous government, but despotism is frightful and leaves no other refuge than death, if it falls into the hands of a ferocious and stupid prince." Mirabeau was not ignorant of the force of the language that he employed. He knew that he would be looked upon "by philosophers, free from prejudices and passions," as a "mad ranter." They would, without doubt,

denounce his work as a veritable signal for revolt. Long experience of men and affairs has taught them that a happy people is insolent; that it is necessary to make it feel its chain; and that the spirit of liberty, inseparable from fanaticism, is the father of rebellion and license. I have known for a long time [comments Mirabeau scornfully] these maxims so often repeated by the slaves of courts; I know that in their opinion the people ought to consider themselves fortunate that they are not forced to sustain themselves upon deserted and sterile fields. Yes, without 


\section{The "Essay upon Despotism"}

doubt, some beings more feeble in body and mind than the rest of humanity ought to command despotically millions of slaves; and it is an effort of generosity to leave them sufficent to sustain their miserable lives. This principle is humane, it is reasonable, and in a century in which the arts, the sciences and philosophy flourish, there is no cause to be astonished that Poland and Denmark are fecundated and nourished by serfs and that Germany and France itself contain some of them. Those whose hearts have not been broken on hearing that four fifths of mankind ought to be unhappy to secure the tranquillity of a few men (and what tranquillity!), to procure them pleasures and enjoyments, can easily believe all the rest.

Despots have need of great audacity, if they reflect upon the consequences of despotism, for it is a dangerous undertaking to attempt to oppress men under the burden of despotic power.

Consider [wrote Mirabeau, addressing himself to the dauphin], consider that in countries where the peoples are serfs, where in consequence they are not interested in public affairs and are not able to watch over their interests, to calculate the advantages that they derive from the administration, to protect their rights, to anticipate the assaults that might be made upon them, to work and to enjoy themselves in peace, to know what they owe and why they owe it, to pay only the taxes necessary for the maintenance and functions of the tutelary authority to which they have submitted for their own greatest good -consider that in such a country there would be neither strength, nor riches, nor unity, nor consistency, nor industry; that such a constitution could not be called society; that it is contrary to nature and hence unstable and full of trouble; that neither soil, nor climate, nor natural resources can resist the terrible influence of such brigandage; that such a kingdom will be poor, burdened with debt, uncultivated, depopulated, invaded by the first to take advan- 
tage of so unhappy a crisis; or rather remember that if a single man awake other men from the slumber of slavery, from that moment you would become the feeblest and the most detested of all malevolent beings, the public victim as you were the veritable national enemy.

Denying that "any man has a right to oppress another," Mirabeau asserted that

the citizen may and ought to defend his liberty with courage and with stubbornness; that that one, even, who would defend it with frenzy would be no more culpable than the one who would precipitate himself with rage upon the ravisher of his wife and his children, upon the assassin who has designs upon his life. ... The tyrants that have died a natural death in their beds may be counted. Injustice, in a word, has often dethroned sovereigns, it has never rendered their thrones stable. The hands of fanatics have been raised against the most beloved princes. What despot would dare to devastate his own estates without fear! What tyrant may hope to oppress twenty millions of people with impunity!

The honest citizen to whom the love of liberty gives the courage to write and publish this work . . . the honest citizen who dares to complain of you to yourself, abhors assassins and would cast himself in front of the mad slave who would raise a criminal hand against you.

But this same citizen would be the first to repulse your mercenary cohorts and to cry out to his compatriots:

The monarch is respectable only when he is the father, the defender, the organ of the country for the advantage of which he was enthroned. Duty, interest, and honour command us to resist his arbitrary orders and even to snatch from him the power, the abuse of which may lead to the subversion of liberty, if there are no other means of saving it. You owe everything to the observance of the laws and you can expect obedience and respect only as related to them. 


\section{The "Essay upon Despotism"}

Adopting the ideas of his father, without acknowledgment, Mirabeau denounced the love of money and luxury as the causes and effects of despotism.

If it is true [he observed], as has been said by one of the greatest writers of our day [Rousseau], that the love of money, or what amounts to the same thing, the consideration accorded to wealth, is the extreme limit of corruption, what period of corruption has been reached by our Europe, entirely mercantile and venal? Luxury [he maintained] is born at the approach of despotism, or rather it is one of the first steps to arbitrary power, for the cupidity and indolence that it produces and nourishes are the first symptoms and the most powerful promoters of servitude.

Luxury and cupidity lead to moral decay, and " bad morals"-his father's idea again-"are the greatest affliction of a state." Elsewhere he remarks that "as soon as a government has introduced luxury and the effeminacy that always follows it, liberty and the state are lost; for men never retrograde from effeminacy to masculine virtues, the sole supports of states and defenders of liberty."

Mirabeau's criticism of a despotic government rested upon a conception of society drawn from the works of French philosophers, but chiefly from the writings of his father. It was the physiocratic view of government. Man is naturally good and just and attains his highest development in society. For not only is "society the natural state of man," but "it may be said that he is not really a man, that is, a thinking and sensible being, until society begins to take shape." Although an admirer of Rousseau, Mirabeau was unable to accept the extreme conclusions that Rousseau had drawn from his study of society. 
Whether man in his natural state [observes Mirabeau] was or was not repugnant to society, it exists, nevertheless, and all the books possible will not be able to dissolve it. It is much better, then, to enlighten it than to show it that it ought not to exist.

M. Rousseau, affected deeply by the corruption of cities, pretends that these institutions have degenerated from their natural condition and render men more unhappy. If we adopt this opinion, let us endeavour to discover remedies or at least palliatives for our woes. This investigation is more useful and more pleasant to make than the satire of men and their societies. . . . It is the science of consolations that interests men. It is the general belief that our condition is preferable to that of the Caribbees . . . and mankind will probably never return to the forest even if nature should produce a new Timon, as eloquent as M. Rousseau, to convert them to that sad kind of life. As for me I cannot persuade myself that man took a false step when he drew near to his fellows.

As sociability ... renders necessary the justice upon which it depends . . . it is evident that unauthorized injustice can only mean the dissolution of every society. Although man is naturally good, the desire to be a despot, to men assembled in society, is as natural as the hatred of despots to those who have not been perverted by slavery. There is no contradiction here [Mirabeau explained], for justice, or goodness (they are the same virtues), consists in exercising a restraint on one's passions, in subordinating them to the general welfare, in which is always found the real and durable good of the individual; but it does not consist in not having passions. . . . This general penchant for invasion once admitted and recognised, one soon feels the necessity of opposing oneself continually to the tyranny that menaces us, since each of us bears the germ of it in his heart. . . . One should learn, furthermore, from a passion so general, so active and so industrious, the necessity of being just; for what right have I to repulse oppression, if I 
oppress? . . . The desire of superiority is the most active passion of the human heart. Let us add that it is impossible for a man who is not restrained by some great interest, not to take advantage of his superiority. The desire to degrade others is bound up inseparably with that to raise oneself. These two passions combined produce tyranny and slavery.

Writers upon slavery have called it the alienation of liberty. "This definition of slavery," observes Mirabeau, "appears to me to be as dangerous as it is false; for it supposes that a man may be permitted to alienate his liberty." He denies that this is possible, as one cannot alienate his personal possessions, meaning his faculties. "Tell the despot," he exclaimed, "who pretends to have been born an absolute master of slaves whom he oppresses and tramples upon at his pleasure, to appropriate their pleasures, their pains, their sensations, their strength, all the faculties, finally, that make up their personal property; he would reply to you perhaps through the hangman; it is the sole argument of tyrants. Let us deplore his blindness, let us detest his principles, but let us never be convinced by violence. It is as shameful to allow oneself to be subjugated by it as it is odious to exercise it."

"If we may not dispose of our own liberty," he went on, "with how much greater reason may we not engage that of our descendants." He characterised the act of serfage known as obnoxiatio, by which men voluntarily placed themselves and their children in a state of servitude, "as the most unbelievable monument of the most iniquitous, most revolting, and most absurd madness that the records of humanity have transmitted to us." This outburst of indignation was followed by the remark that "men forge their chains when they 
make their laws." Codes have been multiplied "and the knowledge of positive law for civilised peoples has become an immense science; its study is more fatiguing for the memory than for the understanding. Such are the works of man, ... more active in perceiving and multiplying exceptions than fitted to seize general principles, to observe and meditate nature." For "nature, without doubt, intended us to have surer and less mobile laws. She has not made individual systems; the rights of all men and all nations are the same, as well as their duties." It is the business of the legislator "to extend and to unite the different applications of the natural law." But what is this law, "obligatory for all and as essentially existent as the sun that gives us light"'? It is not quite clear what Mirabeau understood by it. It was something more than the produit net, although that evidently was a part of the law.

In a passage throwing considerable light upon the question, he wrote that

the duties of all consist in the accomplishment of the law. The law, that is to say order, is founded upon the sensations and the physical needs of man, to whom nature accorded as many faculties to enjoy with as she permitted him enjoyments; it is then in the midst of these enjoyments, it is in their production, their distribution, that must be sought the social code. . . . Society ought to give the greatest possible liberty to the individuals that compose it, by increasing the mass of their properties and multiplying their enjoyments, Without this Law, no more consistency, no more unity, or, to say all in a word, no more society; for the formation of society is only the extension of primitive relations, not their abolition. Now the first natural relations are to give assistance and do good, in order to receive 


\section{The "Essay upon Despotism"}

assistance and be helped. . . . For, in forming themselves into societies, men did not intend and should not have intended to sacrifice anything; they did intend and they should have intended to extend their enjoyment and the benefits of liberty, by reciprocal succours and guaranties. That is the motive of the subordination that they render to the sovereign authority, to which the people has confided its defence and police. Upon this foundation, it is easy to rest the rights of all men and consequently the relative duties of sovereigns and peoples.

Mutual service, in a word, is the law of society. It followed naturally from these assumptions, as

the first principles, the basis of all discussion, source of all truths in matters of government and morals, that we are indebted to society only so far as society helps us, since its object is to benefit the human race, to multiply its forces, its riches and its enjoyments. ... From this truth it evidently follows that man owes obedience to government only in so far as its constitution creates better or more favourable conditions, that is to say, in proportion as it approximates more or less closely to the first and unique motive of its institution.

But in a despotic government, might is the only right; there, a revolutionist cannot with justice be prosecuted more than any other; there is no law but that of the strongest. Justice does not exist; there is no citizen. Man is only a slave; a slave owes nothing, because he has nothing of his own. . . . It is impossible to infringe laws and rules in a government the essence of which is to have none, and this lack of regularity is the vice that ought to destroy everything, for nothing is conserved or reproduced in nature but by fixed and invariable laws.

In a scheme such as this, there was no place for a king responsible alone to God. The king was simply 
the first servant of the state. In language of the most revolutionary stamp, Mirabeau defined the position of a king.

The people [he wrote, addressing an imaginary ruler], whom you command, intrusted to you the employment of its forces only for its own benefit, or what amounts to the same thing, for the maintenance of public security, both internal and external, and for the advantages that it promised itself when it instituted a tutelary authority. You have not torn from them the exercise of their rights, for they were the stronger before they had created you the depository of their power. They rendered you powerful for their own best good. They respected you, they obeyed you, for their own best good. Let us talk more clearly still: they pay you and they pay you dearly, for they hope that you will return more than you cost.

You are, in a word, their first stipendiary, and you are only that; for it is in accord with natural law to be able to dismiss the one that we hire and who serves us poorly, as it is contrary to natural law that each one shall not be free to look into, to become acquainted with, his own interests, and that the rights of man may be arbitrarily diminished by those who have been charged to defend them.

If the prince replied that he "cares not for right when the fact is in his favour," and that he shall "know how to maintain his usurpation in the face of those who have imprudently despoiled themselves of the power to restrain him," Mirabeau reminds him of the danger of such an attitude and recalls the question addressed to a despot: "What would you do, Philip, if all your subjects should decide to say no every time that you said yes?" Nature had made the prince a man and had not given him more organs and faculties 


\section{The "Essay upon Despotism" $\quad 46 \mathrm{I}$}

than to any other. Some of his ancestors "had merited the esteem and love of a numerous and powerful nation," but

peoples are not intended by divine right to serve as beasts of burden or as the sport of princes. . . . Nature has not destined entire Europe to be the plaything of a dozen families.... Your people and you are bound together by the close bond of utility which unites you. If you break it, you will compromise your existence, be it that society will tear from you the power in which it finds only oppression and sorrow instead of protection and prosperity; be it that you will succeed in enervating your subjects by servitude and ruining your country by the ravages of despotism.... You are the stipendiaries of your subjects and you ought to submit to the conditions under which your salary is accorded you, on penalty of losing it.

"Society does not pay him, this public officer," Mirabeau remarks in another place, "to save him trouble, but that he may take that of defending the mass of public riches, and, consequently, the property of each individual." The king had been raised to a commanding position to protect the rights of his subjects and not to encroach upon those liberties. "Where liberty loses its rights," said Mirabeau, "there is the frontier of your empire."

The position of the noble did not differ from that of the king.

The great owe their elevation only to public needs; that the people were made for them is so far from the truth, that they themselves, all that they are, exist only for the people ... for the difference that society has placed between the people and notable citizens, the distinctions that it has established in all the grades of the hierarchy, are for the good of all and not for the exclusive 
advantage of the great; and when one profits by the advantages of a bargain, one cannot with justice evade the conditions that it carries with it, however onerous they may be. Every great man who is not useful to his compatriots is a veritable bankrupt ... and ... nothing is so criminal as to charge oneself with a public function that one is not capable of performing.

The essay contains nothing to indicate that Mirabeau was opposed to a hereditary monarchy or a hereditary nobility. He is not an advocate of democracy or of social equality, but an opponent of arbitrary government and the protagonist of government based upon law. Nature has established laws everywhere and society forms no exception to this rule. Society exists for the good of all its members and rests upon a system of rights and duties. In this society "nothing is given for nothing." Kings and great men, raised above their fellows, have certain duties to perform in return for the benefits that they enjoy. They must govern in accordance with the laws, and if they violate the liberties of those who have chosen them to rule, they are despots. There is nothing here that cannot be found in the writings of the marquis. The work of the son differs from that of the father in form rather than in content.

But how, one naturally asks, shall the king and nobles be forced to obey the law? What checks shall be placed upon their power? Here again Mirabeau shows himself a true physiocrat, finding salvation not in elections, national assemblies, and control of taxation, but in education. The king must learn that it is contrary to his own interest to rule despotically. "Why appeal to force?" Mirabeau asks. "Instruction, this arm more gentle, more powerful likewise with 
time, will suffice for the organisation of societies and will preserve them from the convulsions of violence."

[As] despotism from the side of the sovereign is an unenlightened love of enjoyment, and as consequently submission to despotism on the part of the people betrays ignorance or forgetfulness of their rights, instruct the kings and their subjects and the very foundation is cut from beneath despotism. . . . All the acts of despotism are only combats in the dark among people who, however, fear the blows, for men are inclined to be good and wish only to be at peace. Bring in the light and you will see them all at peace.

This light, at the approach of which civil dissensions, social crimes, public outrages, prejudices, fanaticism are obliterated, is the sole barrier that ought to be raised against all errors, all political brigandage and the ills of society.

Instruction and liberty are the bases of all social harmony and of all human prosperity; I might have said simply instruction, for liberty depends absolutely upon it, since universal instruction is the most inexpugnable enemy of despots. It is evident, and one cannot lay too great stress upon it, that general instruction, that would furnish to each fixed and logical principles and would become the invariable compass of our judgments, would teach us to assign to names, to ideas, to things, their veritable value; and that from this moment we would no longer have reason to fear, for public tranquillity, the illusions that still seduce men after having seduced so many.

It is evident that no man would tranquilly permit his harvest to be burned; but it is quite as evident that if each arbitrary whim, each act of brigandage in finance, each coup d'autorité carried with it, thanks to the universality of instruction, the idea of a social crime as direct as a voluntary conflagration, all would oppose themselves to its execution. 
It is not less certain that if all princes considered the consequences of an arbitrary administration, consequences frightful for men, and not less terrible for themselves, they would take good care not to be despots.

It is then to kings that we must address ourselves. It is they that we must dare to instruct and to bring back to the first principles of nature, from which it is so easy to wander.

[To educate kings, is, however, no easy matter.] The nation, that ought, without doubt, to preside over this education, because it is the most interested in it, not only does not choose the instructors of its princes, but almost always sees them drawn from the class of courtiers, objects of its contempt, if not of its fear. What hope can it conceive of a pupil confided to such hands?

Mirabeau, like the men of his generation, hoped all things from the growth of intelligence as the result of education, but his book contains no definite counsels as to how that education could be accomplished. He would instruct the despot, but he confessed that "the first arms of despots, and those arms whose effects are the most cruel for liberty," are " the obstacles placed in the way of instruction, the prohibitions that hamper the press and the publication of public writings." Despotism deprived him of the very means by which he would overcome despotism.

Although it contained no practical suggestions as to how France might escape from the cul de sac in which it found itself, this first political pamphlet of Mirabeau's was significant in many ways. It was representative of the view of a considerable group of thoughtful men in France at the close of the reign of Louis XV. It showed the frank hostility to arbitrary government, the demand for a government based upon law, and the conception of the monarch as the first 


\section{The "Essay upon Despotism"}

servant of the state, that were characteristic of the thought of the period. It also hinted at the solution of the problem that was about to be attempted by Turgot and his associates, the substitution of enlightened government by an absolute monarch, ruling in accordance with the laws, for the government of an arbitrary king.

This first public utterance of Mirabeau was typical of those that were to follow and revealed him as he appeared to himself, a fearless speaker of the truth, an apostle of liberty, a man who cared not what the judgment of contemporaries might be, but trusted posterity to do him honour. When he cried to princes, "May you on hearing these new truths awake from the profound lethargy in which you have been plunged, arouse your soul to true glory, I mean to say, that of repairing its faults, and cry out, 'Alleviate my people, elevate my nation, there is yet time, for I perceive some traces of dying liberty,' " his appeal may have fallen. upon deaf ears, but his words to the young men of France were not without effect. He called himself a

citizen of the world, brother of all men, faithful subject of good kings, enemy of all tyrants. . . . I have no other interest [he wrote] than that of truth. I have no other occupation than that of publishing it. Persecution does not frighten me, for fortune and favour cannot seduce me; I do not wish that my nation shall merit the reproach that Tiberius made to the Romans and that our princes should have more reason to complain of the baseness of their subjects than the subjects of the repugnance that their princes have to hear the truth.

I have spoken it as I knew it, as I saw it. May I inspire citizens, abler and more eloquent than myself, with the courage necessary to teach their compatriots that each of

vor. $\mathrm{x}-3 \mathrm{O}$ 
them is in society only to draw from this association the greatest good for himself; that a king, chief of society, is instituted by it and for it; that every sovereign who calls himself such by the grace of God resembles Xerxes, enchaining the seas or scourging Mount Athos with rods, if he oppresses his people and that people revolts; for God cannot be other than the inexorable and terrible judge of tyrants.

He had already dedicated himself to this great struggle that was to end with the triumph of law over arbitrary rule; and in words almost prophetic, words that fix the attention with a strange fascination as we read them to-day in the light of his completed life, he spoke of the rewards of such a struggle:

When great men have descended into the tomb, when passions and private interests have vanished, then, when envy is silent, the voice of posterity makes itself heard. Lying illusions disappear; vain clamours are no more; and if great talents and mighty virtues, persecuted and disdained, were more than once the torment of him that nature raised above other men, in his inmost soul he at least knew his own worth; he divined the judgment of posterity. And the tardy tribute of our veneration and our praise teaches those that a noble emulation draws into the thorny road of true glory, that they will find themselves one day in the place that they have merited; and that the judgments of opinion, that alone endure, from which alone no mortal can escape, are equitable soon or late. 
CRITICAL BIBLIOGRAPHY 


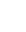




\section{CRITICAL BIBLIOGRAPHY}

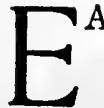

$\mathrm{ACH}$ volume of this work will be accompanied by a critical bibliography of the sources and of the secondary works that have been consulted in the preparation of the volume. This arrangement of three bibliographies, in place of one appended to the last volume, will necessitate some repetition, several works being utilised more than once, but this defect, if it be a defect, will be more than compensated for by the convenience of having each volume complete in itself. The three bibliographies taken together will not form an exhaustive bibliography of Mirabeau literature. They will contain practically all the sources, both manuscript and printed, all the standard biographies, like those of Loménie and Stern, and all the scientific monographs that I have consulted, whether published originally in book form or as articles in reviews. The bibliographies will not contain all the brief popular or semi-popular works that have been written on Mirabeau in French, German, and English, although some of them-those of Mezières, Rousse, Erdmannsdörffer, Willert, and Von Holst, for example-are excellent. ${ }^{1}$ They will not include the standard histories of the revolution like those of Aulard, Blanc, Michelet, Von Sybel and Taine, if I have not had occasion to make specific use of them. The addition of all these titles might increase the bulk but not the value of the bibliography as a bibliography of Mirabeau literature.

1 Mezières, A., Vie de Mirabeau, Paris, r 892; Rousse, Edmond, Mirabeau, Paris r89r; Erdmannsdörffer, B., Mirabeau, Bielefeld, und Leipzig, x900; Willert, P. F., Mirabeau, London, I 898 ; Von Holst, H., The French Revolution Tested by Mirabeau's Career, 2 vols., Chicago, 1894 . 
Such critical discussions of the value of the sources or of the secondary works as may be introduced here and there will, as a rule, have to do with the work as a whole. Some questions that might properly be considered here, such, for example, as the date of the writing of the Essai sur le despotisme, I have treated in the body of the work on account of their close connection with the text. The criticism of specific bits of evidence or specific statements in secondary works is presented in the foot-notes to the volumes.

\section{I-SOURCES}

\section{A-Manuscript Sources}

\section{I-Montigny Collection (Aix en Provence).}

(a) Correspondance gênérale entre le bailli et le marquis de Mirabeau. I 2 volumes in folio. I have adopted for this collection the title employed by M. Guibal in his Mirabeau et la Provence. The letters are found in the first ten volumes, the last two containing the mémoires of the bailli. A letter prefixed to the collection and written by M. Pontier to M. Lucas de Montigny, the adopted son of Mirabeau, April 17 , $r 826$, shows that the letters previously in the hands of $M$. Pontier passed at that time into the hands of M. de Montigny. The following paragraph, describing the collection and giving its history, forms the preface to the first volume and was evidently written previous to 1826 :

"Cette collection manuscrite en I 2 vol. folio, chamois verd, est sortie de la maison sur le Cours [the main avenue in Aix] appartenant à M. l'évêque conseiller, qu'occupait en location M. le Bailli de Mirabeau, frère du Marquis Victor de Mirabeau, auteur de l'Ami des hommes, et oncle du Comte et Vicomte de Mirabeau, fils du dit marquis. Le bailli fut forcé d'émigrer, et pendant son absence le fils de M. l'évêque, pauvre hère et patriote déterminé, fit vendre tous les effets du bailli, parmi lesquels se trouvaient les 


\section{Critical Bibliography}

manuscrits susdits qui avaient été copiés successivement sur les originaux par un secretaire affidé au bailli pendant longues années et nommé Bertrand. Ce fait est certain et ces manuscrits peuvent être considérés comme autographes et sans altération. Iis sont très curieux, riches d'observations, et ne peuvent être que fort utiles aux déscendants de cette famille et productifs par l'impression des matériaux qu'ils renferment sur la marine de France. L' acquéreur les sauva d'une déstruction certaine, car ils allaient être vendus à des épiciers."

These twelve volumes contain, then, not the originals of the letters that passed between the bailli and the marquis, but copies of them. That the most of these copies were made by the secretary of the bailli is possible, but they are not all his work. Three letters, at least(Correspondance générale, vi., 38r) are in the handwriting of Mirabeau. As these letters were written by the marquis at Aigueperse, after the arrival of Mirabeau from Provence, M. Charles de Lomenie inferred (iii., 50) that they were copied at that time "dans le recueil où le marquis fait soigneusement transcrire sa correspondance, copiée de la main de celui même qui en est en grande partie l'objet. Mirabeau sert à ce moment de secretaire à son père." I have adopted this inference of $\mathrm{M}$. de Loménie, although he has not given his reasons for his conclusions.

The fact that the documents came from the house on the "Cours" occupied by the bailli and the tradition that the letters were copied by Bertrand would seem to weaken the strength of the inference of $M$. de Lomenie, but an examination of the correspondence shows conclusively that if Bertrand really copied the letters he could not have done so at the time of their receipt and despatch, but at a much later date, and that the letters were arranged artificially before they were copied. For example, in vol. i. we have this order: The chevalier to the marquis, Martinique, Dec. 4, 1753 ; the marquis to the chevalier, Paris, May 13 , 1754; the chevalier to the marquis, Martinique, Dec. 24, 
I 753; the marquis to the chevalier, Paris, May 24, I754; the chevalier to the marquis, Guadeloupe, Jan. Io, I754. Now, if this collection belonged to the bailli and he had copied the letters at the time of their despatch or receipt, the dates would have run: Martinique, Dẹc. 4, I753; Martinique, Dec. 24, r753; Guadeloupe, Jan. Io, I754; Paris, May I3, I754; Paris, May 24, I754; for the bailli wrote his three letters before the marquis wrote his, and the letters of the marquis could not have been received and copied before they were written. If the collection belonged to the bailli, the copying was done later. The same reasoning would not apply to this illustration if the collection belonged to the marquis. The order of the volume might be the order in which the letters were despatched and received. This is also true of the other volumes that I have examined. If the copies were made by Bertrand, how did three letters in Mirabeau's handwritting get into the volumes? It might be answered that Mirabeau copied them when he was with his uncle in Provence from October, I 782 , to September, 1783 . To render that possible, however, we must assume that the copying had already begun and had advanced so far when Mirabeau appeared that he could copy three letters-why only three?-in their proper place. This hypothesis that the bailli made copies of all the letters sent to the marquis and retained the originals received from the marquis, at a later date rearranged them, had them copied into volumes by his secretary, and that, during the copying, Mirabeau appeared and copied in their proper place two letters written from Aigueperse by his father in 1770 and one received from his uncle at the same timethis hypothesis seems less reasonable than the other, that the copying was done at the time of the despatch or receipt of the letters by the secretary of the marquis, that Mirabeau copied the three letters at Aigueperse, and that after the death of the marquis the collection passed into the possession of his brother.

The question as to who copied the letters is not, however, 
of vital importance. An examination of the collection by any competent judge will convince him that it consists of reliable copies of the letters of the marquis and of the bailli. That is the important thing. Of course, if the three letters copied by Mirabeau were copied at Aix in 1783 , instead of at Aigueperse in I 770, the statement that Mirabeau was acting, at that time, as his father's amanuensis would not be true. I must confess that, on reading the letters copied by Mirabeau, letters containing such flattering references to himself, I was somewhat surprised that his father allowed him to copy them. It seems much the more natural thing that they should have been shown to him by the bailli in 1783 . It seems strange, also, at first thought, that his father should have permitted him to copy these three letters and no others, but further consideration suggests that the whole thing might have been done as a pure proof of confidence on the part of the marquis. There would seem, then, not to be sufficient reason to reject the hypothesis of $M$. de Loménie.

When these letters were rescued from the grocerymen, the history of Mirabeau's youth had not been written; had they been destroyed, it never would have been written satisfactorily. Since passing into the possession of the Montigny family, the collection has been used three times: by M. Lucas de Montigny for his well-known work, Mémoires de Mirabeau ( 8 vols., Paris, I 834, I 835), by MM. Louis and Charles de Loménie in their remarkable study on Les Mirabeau (5 vols., Paris, 1879-1891), and for the present volume on The Youth of Mirabeau. Practically all the references to Mirabeau, found in the letters, have been utilised in these three works. They form, however, but a small part of the correspondence. The bulk of it is still unpublished and offers abundant material for a monograph upon the work of the bailli as an officer of the French navy and especially as a colonial governor. His mémoirs deal with the condition of the colonies.

The value of these letters for the life of Mirabeau is self- 
evident. They contain the record of his early life as seen by his father and his uncle, recorded from day to day and from year to year. They are not all, however, of equal value. The later letters in which the marquis or the bailli refers to earlier events are valuable, but not so valuable as the record made at the time of the event. It is for this reason that I have throughout the volume insisted upon the date of the letter, that it might be clear to the reader whether the evidence was strictly contemporary or not. In utilising these letters, it must be remembered that, as a rule, the marquis was an unfriendly witness, while the bailli was a friendly one. There are, however, marked exceptions to this rule. During the period when Mirabeau enjoyed the confidence of his father, the marquis passed to the opposite pole in his attitude toward his son. The bailli frequently relapsed from his favourable attitude and at times became extremely hostile to his nephew. It is necessary, therefore, to keep trace of these shifting attitudes in order to attain to a correct evaluation of the evidence.

(b) The Minto Manuscripts. This collection of letters written to Mirabeau by his wife, by Madame de Vence, and others-also the letter of Mirabeau to Gassaud-during the years $r 773$ to 1783 , received its name from the fact that for about sixty years, 1785 to 1846 , it was in the possession of Sir Gilbert Elliot, afterwards Lord Minto, and of his descendants. Elliot was a school friend of Mirabeau's at the Choquard pension, and while in England ( $1784-\mathrm{r} 785$ ) Mirabeau intrusted this package of letters to Elliot for safe-keeping. The package bears the following inscription: "Paquet que mon cher Elliot ne remettra jamais qu'à moi, ou sur un billet circonstancié de moi, écrit en pleine liberté, parcequ'il importe infiniment à la justification de ma vie toute entière et qu'il est un des plus précieux monuments de mon honneur." (Loménie, iii, rr6, note r.) It is a curious thing, this solicitude of Mirabeau, long years before he became famous, concerning the opinion of posterity. An examination of the chapters in which $I$ have utilised 


\section{Critical Bibliography}

these letters will demonstrate the correctness of his estimate of their value. They rescue from obscurity several important incidents of his early life, and even when critically evaluated their testimony is distinctly favourable to him. The letters did not pass into the possession of M. de Montigny, transmitted to him by the descendents of Sir Gilbert Elliot, until the Mémoires had been published. "C'est seulement dix ans après la rédaction de ce grand ouvrage et douze ans après sa publication," he wrote in a note prefixed to the collection, "que ce précieux dépôt m'a été remis. S'il avait été plutôt en ma possession, j'aurais tiré un parti utile de plusieurs lettres de la comtesse de Vence. A comparison of the account of the Gassaud affair in the Mémoires (ii., 30) with the accounts in Lomenie (iii., ro8-r r6) and in my own volume (Chapter XV.) will show how useful the letters of the Comtesse de Vence might have been to $\mathrm{M}$. de Montigny.

(c) Letters of Mirabeau and of his Wife. (r). Five letters of Mirabeau to M. or to Madame de Limaye and Mirabeau's declaration of his responsibility for the notes indorsed by M. de Limaye, all written in April, I 774, some at Mirabeau and some at Manosque. These letters supply important information concerning the methods employed by Mirabeau to raise money immediately after his marriage and indicate how disastrously his family relations were influenced by money affairs. (2). Letters of Mirabeau to the Duc de Nivernois (Paris, July $21, x_{7} 68$ ), to his mother (Ile de Re, March 5, r768), to Madame du Saillant (Aix, June r 7, I 772), to his mother (Mirabeau, August I8, r772), to Madame de Vence (Manosque, May 3, I774); letter of the Marquis de Marignane to the bailli (Aix, June $\times 7$, 1772); letter of the Comtesse de Mirabeau to Gassaud (Manosque, May 28, I 774 ). All of these letters help to piece out and to render more definite our knowledge of Mirabeau's life from $x 768$ to 1774 .

2-Collection of M. Paul Arbaud (Aix en Provence). The Mirabeau manuscripts of M. Paul Arbaud bear chiefly upon the period of Mirabeau's life that I shall treat in my 
second volume. For this volume, I have made use of but four pieces: (I) Lettre de cachet for the arrest of the Marquis de Mirabeau ( 1760 ); (2) Song sung at Aix in 1783 ; (3) Letter of Madame de Mirabeau to Madame de Roquessante (Mirabeau, September, I 772); (4) Letter of Mirabeau to $M$. de Roquessante (without place or date, probably Mirabeau, September, I772).

3-Collection of M. L. de Berluc-Perussis (Aix en Provence). Letter of Montvallon on the youth of the Comtesse de Mirabeau (Aix, April 27, I763).

4-Collection of $M$. Sigaud de Bresc (Aix en Provence). (I) Four letters of Mlle. de Marignane to her father, written in the years 1768 to 1770 . Portions of these letters have been published by M. Guibal in an appendix to the first volume of his Mirabeau et la Provence; (2) letter of the Marquis de Mirabeau to the intendant of Provence urging him to propagate the doctrines of the Physiocrats (Mirabeau, May I2, I768).

5-Collection of M. Garcin (Apt en Provence). (I) Letter of Madame de Roquessante (probably June, I772, Aix), in which she writes of the engagement and coming marriage of Mirabeau; (2) letter of Mirabeau to Madame de Roquessante (Aix, June 17, I772); letter of Mirabeau to Madame de Roquessante (Mirabeau, August 26, r772).

6-Collection of $M$. Mouttet (Aix en Provence). The collection of M. Mouttet is largely composed of copies. Most of the letters enumerated above, with the exception of the Correspondance generale, figure in this collection. Some of these copies he had incorporated textually into his Mirabeau en Provence; others, like the Minto manuscripts, formed a carton by themselves. As he kindly permitted me to take these with me to America, they were employed in the construction of my narrative and are still in my possession. Besides the copies of the documents already mentioned, the collection of M. Mouttet contained the following that have been utilised in my first volume: (I) Analysis of the record of the sale of the chateau de 


\section{Critical Bibliography}

Mirabeau, April 25, I 570, to Jean Riqueti (Archives départementales des Bouches-du-Rhône, register B, 62 (Capricornus); (2) copies of the seven documents relating to the establishment of a trading and manufacturing company at Marseilles of which Jean Riqueti was a member (Archives départementales des Bouches-du-Rhône (see detailed reference in note to Chapter II.) ; (3) letter of Madame de Mirabeau to Madame de Roquessante (probably written at Mirabeau, September, I772).

7-Archives nationales (Paris)

(a) $\mathrm{K}, \mathrm{I6}_{4}$, No. 2. The letters and documents relating to the arrests and imprisonments of Mirabeau during the year 1774. They consist of letters of the marquis, of Marignane, of D'Albertas, and the official documents connected with the exile and imprisonment of Mirabeau. This material was unknown to M. de Montigny. As a result his treatment of the year $\mathrm{I} 774$ is very unsatisfactory on account of its lack of clearness. They were used for the first time by Professor Stern in his Das Leben Mirabeau (vol. i., Berlin, I889), and almost at the same time by M. Charles de Loménie in Les Mirabeau (vol. iii., Paris, r889).

(b) M, 783. The manuscripts of the Marquis de Mirabeau. The carton contains the Journal of the marquis's youth (eight pages have been separated from the Journal and are -or were a few years ago-found in $M, 784$ ), extracts from his letters to the intendant de Brie (Nov. Io, I770, to Nov. $8,1788)$, accounts of the campaigns in which he took part, and a large number of mémoires and studies on political and economic subjects.

(c) $\mathrm{MI}, 784$. Other manuscripts of the marquis, among them the plan for a course in economics at the Choquard pension. referred to in Chapter VI.

(d) Y, 499r. The documents, nine pieces, referring to the interdiction of Mirabeau. Three of them have been published by M. Alfred Bégis. (See Printed Sources.) The account of the interdiction of Mirabeau, in Chapter XIV. of this volume, is based upon these documents and is 
the first detailed account of the subject that has been published.

\section{B-Printed Sources}

Argenson, Marquis de. Mémoires, 9 vols., Paris, I859; 5 vols., Paris, 1857 .

Barbier, E. J. F. Journal, 8 vols., Paris, 1866.

Brette, A. "Les services militaires de Mirabeau" (La révolution française, xxix.).

This article contains the reprints of documents upon the military career of Mirabeau, found in French archives.

Bégis, Alfred. Mirabeau, membre de l'assemblée constituante. Son interdiction judiciaire. Paris, 1895. This pamphlet-only a very limited number of copies was printed -is little more than a source publication, containing three of the nine documents in the Archives nationales ( $Y, 499 \mathrm{I}$ ) relating to the interdiction of Mirabeau. No attempt was made to weave them into a narrative, supplementing them with other sources.

Desmoulins, Camille. La France libre, I789.

Dumont, E. Souvenirs sur Mirabeau. Bruxelles, $183^{2}$. In my first volume I have referred to Dumont but once, on the matter of Mirabeau's strategy in winning his wife. What Dumont gives us is evidently nothing but gossip, hearsay evidence, and has practically no value. It was only in 1788 , sixteen years after the event, that Dumont met Mirabeau (Souvenirs, 25), and the Souvenirs were written more than ten years after that (see pages I9 and 20). I shall criticise this work more in detail in one of the following bibliographies.

Elliot, Sir Gilbert. Life and Letters. 3 vols. London, 1874. Contains a description of Mirabeau, as he was at the Choquard pension, by Elliot, who, at the time, was a school-mate of Mirabeau's.

Flammermont, Jules. Remontrances $d u$ parlement de Paris en XVIII ${ }^{\circ}$ siècle. 3 vols. Paris, $1888-1898$.

Gilbert, D. L. Euvres posthumes et cuvres inédites de 


\section{Critical Bibliography}

Vauvenargues. Troisième édition. 2 vols. Paris, I 857 ; one volume-they are not numbered-contains the correspondence of the marquis and of Vauvenargues, a very important source for the youth and young manhood of the marquis.

Gleichen, Charles-Henri. Souvenirs. Paris, 1868. Gleichen was an intimate friend of the Mirabeau family. Connected with the court at Bayreuth and a friend of Count Louis-Alexandre de Mirabeau, he conducted the negotiations (see page 116 of the Souvenirs) that led to the reconciliation of the brothers. He passed considerable time in Paris, between $I 753$ and $I 770$, and was so frequent a visitor in the Mirabeau household that, to quote his own words, he became "l'enfant de la maison" (p. II 7 ). He certainly had an opportunity to observe the treatment of Mirabeau by his father. It is true that the Souvenirs were written after 1804 (see page 66, where Gleichen refers to the death of Necker), that, meanwhile, Mirabeau had died famous, and that Gleichen would be naturally inclined to play the prophet in announcing that he had said to the marquis that he would make of the boy "un grand scélérat, pouvant en faire un grand homme." But even if we doubt the genuineness of this posthumous prophecy, it cannot be denied that when Gleichen characterised the marquis as "vaniteux" (p. I15), and asserted that Mirabeau was treated at home in a "despotique, avilissante et haineuse" manner, because "il était laid et indomptable par les châtiments" (p. II6), his memory is not entirely playing him false.

Garat. Mémoires historiques sur la vie de M. Suard. 2 vols. Paris, I 820 .

Hausset, Madame du. Mémoires. Paris, 1824.

Isambert. Recueil générale des anciennes lois françaises. 30 vols. Paris, I821-1833.

Journal de Paris. January I, I 777-September $30,1811$. 87 vols.

Loménie, Louis de. La Comtesse de Rochefort et ses amis. Paris, 1879. This volume contains a considerable number of letters that passed between the marquis and Madame de 
Rochefort, as well as letters between Madame de Pailly and the countess. The relation of the Comtesse de Rochefort to the Duc de Nivernois was similar to that of Madame de Pailly to the Marquis de Mirabeau. In this volume, M. de Loménie has made a valuable contribution to our knowledge of the peculiar matrimonial relations in the best families in France in the second half of the eighteenth century. It is from such studies as this that we learn that Mirabeau's notoriety, due to his relations with Madame de Monnier, for example, was rather the result of his indifference to public opinion in the matter of conventionalities than of his violation of the moral law.

Marais, Mathieu. Journal et mémoires. 4 vols. Paris, 1863.

Mably. Des droits et devoirs du citoyen. Paris, 1893.

Mirabeau, Comte de. Observations sur un libelle diffamatoire intitulê: Mémoire d consulter et consultation pour Madame la Comtesse de Mirabeau. Aix, I783.

This is one of the judicial mémoires published by Mirabeau in opposing the request of his wife for a divorce at Aix in 1783 . It contains copies of a large number of letters of the countess, addressed to Mirabeau, and statements of Mirabeau concerning his early life.

- Observations pour le Comte de Mirabeau. Aix, 1783 . Another mémoire published in connection with the same trial.

Essai sur le despotisme. Londres, I775. Actually printed at Neufchâtel. In this volume, I have been concerned only with the writing of the Essai; in the second volume, I give an account of the printing of it.

- Lettre de M. de S(aint)-M(athieu) aux auteurs de la Gazette Litterraire. This letter is prefixed to the third edition of the Essai sur le despotisme, printed at Paris in 1792. It was written by Mirabeau while in Holland. It exists in pamphlet form, bearing the date 1777 (Bibliothèque nationale, Loménie, iii, 282, v., 472). Professor Stern examined the files of the Gazette for I 776 and 1777 without 


\section{Critical Bibliography}

finding the letter. M. de Saint-Mathieu was the name by which Mirabeau was known in Holland. It was the name of a fief of his mother's in Poitou.

Lettres originales de Mirabeau, êcrites du donjon de Vincennes pendant les années $\mathrm{x} 777,{ }^{7} 78$, '79, '80. 4 vols. Paris, I792. These are the famous letters of Mirabeau written to Sophie de Monnier during Mirabeau's imprisonment at Vincennes. One of the most important sources upon the life and character of Mirabeau, their use is hedged in by some very serious critical difficulties. They were published by Manuel in r 792. Where did he find them? Has he reproduced them exactly? Has he smuggled into the collection, letters that Mirabeau did not write? These questions form one group of problems. When were the letters written (many are not dated, or incorrectly dated)? Did all the letters in the collection pass through the hands of the prison authorities, or are some of them part of a secret correspondence? Did they all reach Sophie de Monnier? These questions form a second group of problems. Last of all arises the question of the influence, upon the composition of Mirabeau's letters, of the fact that they were read by a police officer before they were sent to Madame de Monnier. I shall make no attempt here to answer these questions, as I have consulted for this volume little beside the Mémoire addressed by Mirabeau to his father, found in the first volume of the letters. In the bibliography of my second volume, I shall make a critical study of the collection. For the present, a brief statement must suffice.

Manuel, who was one of the "vainqueurs de la Bastille" and "un des administrateurs de la police" in Paris, found some of the letters-so at least he claims in the Discours préliminaire to the first edition-" sous les débris de la Bastille, quelques-unes à la mairie." Letters written to Sophie, Manuel tells us, were returned to the authorities after being read. "Elles revenaient tomber avec mépris ou dans la poche de l'inspecteur ou dans le panier inutile des plaçets. Eparpillées par la révolution, je les ai ramassés

vor. $\mathrm{x}-3 \mathrm{I}$ 
partout d'une main respectueuse." $\mathrm{He}$ did not find all his letters, however, in the bureau of police or at the mairie. "Beaucoup," he asserts, "m'ont été ou prétées ou vendues, ou données par les amis de Sophie et de Gabriel; toutes abandonnées par Gabriel lui-même." He was a friend and admirer of Mirabeau and claims that he spent a year before the death of Mirabeau in collecting the letters. Mirabeau, he affirms, knew what he was about and requested him not to publish the letters until after his death, as "on ne veut pas encore me connaitre." Mirabeau added that his family would give much to prevent the publication of them.

Manuel did not simply collect and publish the letters; he acknowledges that he arranged and supplemented them: "Déchirées et presque effacées par le temps, au milieu de ces monceaux de papiers étonnés de se trouver ensemble, il m'a fallu quelquefois sentir somme lui pour devenir ce que je ne voyais plus. . . J J'ai tout recueilli, tout rapproché; ces débris de l'amour étaient pour moi des reliques, et mon cœur a suppleé à mes yeux." In a word, he acknowledges that he supplied what was lacking in the letters that he published, but nowhere does he indicate what, these additions were. He has evidently supplied missing dates; sometimes, he has used the same material more than once; whether he has actually fabricated letters may be difficult to determine.

Manuel has been severely criticised by M. de Montigny, the writer of the Mémoires de Mirabeau (ii., 230-256). M. de Montigny maintains that all the statements made by Manuel concerning the publication are unreliable; he dwells upon the carelessness of his editorial work and upon the reprehensible manner in which missing portions of letters were supplied. M. de Montigny charges Manuel with stealing the letters from the cartons in which they were preserved in the police office. As procureur of the commune of Paris he had access to these cartons. Manuel's statement that Mirabeau knew of his purpose and offered no objection to it, M. de Montigny characterises 
as an "infame mensonge." He states that an unsuccessful attempt was made by Madame du Saillant to prevent the publication. As to the editorial work, M. de Montigny claims that letters are misdated and out of place, that letters written to other persons are attributed to Sophie, and that Manuel used the same material more than once. The last charge might be difficult to sustain, as Mirabeau was quite given to repeating himself, when he thought he had a good thing, and the single example cited by $M$. de Montigny (Lettres originales, i., I 73, 403; ii., 365), certainly does not prove his case. The most serious charge made against Manuel by $M$. de Montigny is that he drew upon his imagination to supply what was missing in the letters. Manuel, as I have already shown, does not deny this. "Nous pourrions prouver," writes M. de Montigny, "en prèsence des originaux dont quelques-uns sont entre nos mains que tel commencement, ou tel fin, tel morceau pris dans le corps d'une lettre imprimé, sont de pure invention, et n'ont pu qu'être fabriqués par l'éditeur." In the summer of I904, I ran across some of the originals of these letters in the British Museum. A comparison with the reproductions in the published collection showed that Manuel had done his work with scrupulous exactness. The principal complaint of M. de Montigny against Manuel is that he did not suppress some of the letters, but published them all, good and bad. That is, of course, a question of morals and not of historical criticism. Concerning the Mémoire, the portion of the collection that I have principally used for this volume, M. de Montigny declares (ii., 250) "la partie du premier volume où est inséré le Mémoire apologétique ... exempte de toute espèce de tache."

Mirabeau, Marquis de. Journal de ma vie. (Revue rétrospective, Sept., Oct., I834). The manuscript is in the Archives nationales, $\mathrm{M}, 783, \mathrm{M}, 784$.

L'ami des hommes. Paris, 1883 .

- Theorie de l'impôt. r 76r.

Montesquieu. De l'esprit des lois. Amsterdam, r749. 
Minto, the Countess of. A Memoir of the Right Honorable Hugh Elliot. Edinburgh, 1868.

Hugh Elliot was a brother of Gilbert and also an inmate of the Choquard pension at the same time with Mirabeau. The first chapter of this volume contains extracts from the boys' letters in which they speak of Mirabeau.

Mouttet, Alexandre. Documents inédits sur Mirabeau. Aix. This pamphlet contains the "contrat et acte de mariage."

Oncken, A. Der ältere Mirabeau und die ökonomische Gesellschaft in Bern. Bern, I886.

In the appendixes are a letter of the marquis and several of Le Trosne referring to the marquis.

Pallain, M. G. La statue de Mirabeau. Paris, 1883. Contains a picture of the house (no longer in existence), where Mirabeau was born, copies of the baptismal record and of other documents.

Ribbe, Charles de. Lettres inédites du Marquis et du Comte de Mirabeau. (Mémoires de l'Académie d'Aix, viii., 391). Two letters of the marquis, one written to his eldest son (February, I77I), the other to the elder Gassaud (April, I774).

Streckeisen-Moultou, M. G. J. J. Rousseau, ses amis et ses ennemis. 2 vols. Paris, 1865 . Contains letters of the marquis to Rousseau.

Tableau de la constitution française. Paris, 1771.

\section{II-SECONDARY WORKS}

Aubertin, Charles. L'esprit public au XVIII siècle. Troisième édition. Paris, 1889.

Berluc-Perussis, L. de. Lettres inédites de "l'Ami des hommes." Digne, I89g. This work contains a selection of the marquis's letters from the Correspondance générale and properly belongs under the printed sources, but as I have consulted only the introduction, I introduce it here.

Brocard, Lucien. Les doctrines économiques et sociales du 


\section{Critical Bibliography}

Marquis de Mirabeau, dans "l'Ami des hommes." Paris, rgo2.

Demolins, Edmond. Les Français d'aujourd' hui. Paris, 1900.

Flammermont, Jules. Le Chancellier Maupeou et les parlements. Deuxième édition. Paris, r 885 .

Guibal, G. Mirabeau et la Provence. 2 vols. Vol. i., first edition 1887 , second r $90 \mathrm{r}$; vol. ii., r $89 \mathrm{r}$.

An exhaustive and scholarly work. It is difficult to see how any historian in the future can find such favourable conditions for a study of Mirabeau and Provence as were enjoyed by M. Guibal. A professor of history at the University of Aix-Marseille, passing long years in the midst of places familar to Mirabeau, constantly associated with men whose interest in Mirabeau was almost a cult, having access to manuscript material that is very likely to disappear with time, labouring patiently and carefully at his task, he acquired a knowledge of the subject that made it possible for him to produce a monograph that is final. I have made frequent use of the first volume.

Joly, M. A. Les procès de Mirabean en Provence. Paris, 1863. The standard monograph upon the Villeneuve affair at Grasse, based upon the official records of the trial.

Lavergne, Léonce. Les économistes françaises $d u$ dixhuitième siècle. Paris, 1870 .

Loménie, Louis de. Beaumarchais et son temps. 2 vols. Deuxième édition. Paris, I 858.

Loménie, Louis et Charles de. Les Mirabeau. 5 vols. Paris, I879-1891.

A remarkable work with an equally remarkable history. M. Louis de Loménie, a distinguished professor of the Collegge de France, had already acquired an enviable reputation by his works on Beaumarchais and on the Comtesse de Rochefort, when the liberality of M. de Montigny made it possible to undertake a more ambitious and more formidable task, the history of a French family in the eighteenth century, the Mirabeaus. He did not live to complete his 
work and under ordinary circumstances the years of labour that he had given to the investigation and to the preparation of the first two volumes would have been lost. But Madame de Loménie was a woman of superior character and ability. She had been closely associated with her husband in his work and saw to it that his efforts were not in vain. Aided by her son, M. Charles de Loménie, the first two volumes were prepared for the press. Inspired by his mother, M. Charles de Lomenie prepared himself to complete the task that his father had begun. It was no small undertaking to acquire the special and general knowledge that would enable him to continue worthily the biography that had been so brilliantly begun by his distinguished father, a trained investigator and a most skilful writer, but he carried it to a successful issue, thus completing a great work in a manner creditable both to his head and to his heart. How well the work was done can be fully appreciated only by one who has followed in his footsteps.

$\mathrm{My}$ indebtedness to this great work is visible on nearly every page. I found the way cleared for me and my task lightened. In the preparation of my first volume, the first three volumes of MM. Louis and Charles de Loménie have been constantly before me. As my work is a biography of Mirabeau and not of the Mirabeaus, it corresponds only to the last three volumes, the work of M. Charles de Loménie. I have used some material that he did not use, but, on the other hand, have not had access to some of the letters that he employed. My conception of Mirabeau's life as a whole is somewhat different from his and I have at times differed with him in the interpretation of the evidence. He impresses me as unsympathetic toward Mirabeau, while I impress him - so he wrote me, after kindly reading over a published chapter of this book-as leaning too far in the opposite direction. But, whatever his attitude, toward Mirabeau, he has endeavoured to do him strict justice. After all, to quote M. Mézières in the Avant-propos to his Mirabeau, "Le spectacle du monde nous apparait toujours 


\section{Critical Bibliography}

un peu à travers nous-mêmes," and it would be, perhaps, a little suspicious if my conception of Mirabeau agreed in all things exactly with that of M. Charles de Loménie.

But it is not simply to the writings of M. Charles de Leménie that I am indebted. He gave me a most hearty welcome to Paris, talked with me about my work, loaned me material, and responded at once to any request for advice or information. As a result of his criticism of Chapter IX (published in the American Historical Review, July, I 9०3), $I$ have made some modifications in the text and notes.

Mouttet, A. Notes et souvenirs. A collection of newspaper articles, published in 1877 .

- G. Lucas de Montigny. Aix, 1895.

- La galérie du Chateau de Mirabeau. Aix en Provence. 1894.

The above works are simply pamphlets, from which may be gleaned bits of information not to be found elsewhere. Nothing connected with Mirabeau was too insignificant to fix the attention of M. Mouttet.

- Mirabeau en Provence. Manuscript. This was the most serious piece of constructive work that M. Mouttet did. A friend to whom the manuscript had been loaned lost a portion of it and M. Mouttet never had the heart to do it over again. He will always be remembered not for what he wrote upon Mirabeau, but for the generosity with which he assisted those who did write.

Montigny, Lucas de. Mémoires biographiques, littéraries, et politiques de Mirabeau, écrite par lui-même, par son père, son oncle et son fils adoptif. 8 vols. Paris, I834, I835.

This is the work from which all writers of biographies of Mirabeau, before MM. Louis and Charles de Loménie, drew their information concerning Mirabeau's youth. These later biographers employed the manuscripts that M. de Montigny had used, and had access to material that he did not use, thus rendering antiquated a large part of his work.

It is difficult to approach the volumes of M. de Montigny 
in the spirit of unsympathetic criticism, when one is acquainted with the motives that induced him to write them. Mirabeau adopted him when he was an infant, cared for him, loved him, and provided for him in his will. The devotion of $M$. de Montigny to the memory of his adopted father was a veritable cult. He passed his life in collecting everything that was in any way related to Mirabeau; he bought and restored the old chateau on the Durance, then in ruins, and, finally, he wrote this work as a lasting monument to the memory of Mirabeau and a justification of his life. It was not the work of a historical scholar, striving to do even-handed justice to his subject and to lay bare the truth, but of a devoted son desirous of hiding forever the blots on the reputation of a revered father and making known only what was noble and lovable. He does not conceal his purpose and acknowledges frankly that he has destroyed sources that would have revealed Mirabeau in an unfavorable light (i., 3I2). He scourges Manuel more for having published without reserve all the letters of Mirabeau to Sophie de Monnier than for having manipulated his sources. He doubtless had a right to do what he would with his own, and he concealed nothing of his partisanship or of his avowed purpose to do all he could for the fame of Mirabeau. He himself places the reader on his guard. The most astonishing thing about it all is his unexampled generosity in allowing M. Louis de Loménie to use all the material in his possession, knowing that it might lead to the construction of a biography that would be the undoing of his own work. His willingness to aid the historian was as admirable as his devotion to Mirabeau. Whatever one may think about the character of Mirabeau, there can hardly be two opinions concerning that of $M$. de Montigny.

The earlier biographers of Mirabeau, who used without control the extracts from unpublished sources that fill the pages of M. de Montigny's volumes, built on a very unsound foundation. The dates of his foot-notes are frequently 


\section{Critical Bibliography}

wrong and the text of the extracts is often incorrectly reproduced. I attempted to lighten the labour of copying the Correspondence gênerale by collating the extracts in M. de Montigny with the original letters. It was not often that much was gained by it, for the text was at times so corrupt that it was easier to copy the original than to correct the copy. The inaccuracy in the dates of the letters cited, and in the text of the extracts, must be due principally to carelessness, for it is not clear what could be gained by systematic falsification. Anyone who has prepared a manuscript, swarming with dates and quotations, for publication knows how difficult it is to attain to perfect accuracy.

A considerable portion of the sources that M. de Montigny had collected he destroyed because of their contents; another portion has disappeared. I have felt obliged, at times, to make use of the material quoted in his work, even when I was unable to verify it, but I have always indicated the origin of the information and warned the reader that any portion of my narrative that rests alone upon the extracts of M. de Montigny, may prove to be unsound.

Oncken, A. Der ältere Mirabeau und die ökonomische Gesellschaft in Bern. Bern, I886.

(Peuchet.) Mémoires sur Mirabeau. 4 vols. Paris, 1824. The best biography of Mirabeau before the appearance of the work of M. de Montigny. It contains numerous extracts from rare printed sources and is still not without its use.

Richard, A. L'esprit Bas-Alpin. Digne, I894.

Rocquain, F. L'esprit révolutionnaire avant la réoolution. Paris, 1878 .

Rousse, Edmond. Mirabeau. Paris, I89I.

Ribbe, Charles de. Les familles et la société en France avant la révolution. Quatrième édition. 2 vols. Tours, I 879 .

Un journal et un journaliste à Aix avant la réoolution. (Mémoires de l'Académie d'Aix, viii.) 
Ripert, Henri. Le Marquis de Mirabeau. Paris, Igor. A study upon the marquis as an economist.

Stern, Alfred. Das Leben Mirabeaus. 2 vols. Berlin, 1889. A most excellent biography and one that has been exceedingly helpful to me in my work as a whole. I have been able to make but little use of it in this first volume, apart from the admirable chapter on the Marquis de Mirabeau as a publicist, the most scholarly single chapter on that topic that I am acquainted with. The treatment of Mirabeau's early life in Professor Stern's biography is very brief and he did not make use of the Correspondance générale. This condensed treatment was obligatory on account of the scale on which the work was planned. Professor Stern has shown generosity equal to that of $M$. Charles de Lomenie in contributing to the success of my work. My obligations to him will be more evident in the second volume than they have been in this.

- La vie de Mirabeau. 2 vols. Paris, 1895, I896.

This work is not simply a translation from the German. In revising his German text for the translation, Professor Stern made use of the last three volumes of $M$. Charles de Lomenie and some other material that had appeared after the publication of his life in German. The French work is, then, really a revised second edition. 


\section{APPENDIXES}





\section{APPENDIX I}

MONG the manuscripts of M. Sigaud de Bresc of Aix,
I found a letter of the marquis that shows 1 another side of his labours as a propagator of the "doctrine." It is dated at Paris, May, I 2, I768, and is apparently addressed to the intendant of Provence. After thanking him for the manner in which he has terminated "cette tracasserie du chemin de Mirabeau," he adds that he takes advantage of this opportunity "pour vous ouvrir mon âme tout entière et vous marquer le désir et l'espérance que j'ai de trouver un véritable patriote en vous." The marquis had been so pleased with his administration that he was led to point out to him that he might become "le createur enfin du patriotisme bien entendu dans notre province. Certes vous m'en remercierez un jour." Then followed an interesting bit of personal history: "A peine mes yeux se sont ouvertes et ma tête a commencée à agir que l'ambition de faire de grandes choses devint ma passion dominante; je compris avec le temps que pour cela il fallait les faire bonnes, et d'entre celles-ci, je n'en pus connaître et concevoir de meilleurs que celle de faire bien à nos semblables et à nos concitoyens." As the result of reflection, he had reached two conclusions: "r, On ne sçaurait gouverner à sa guise que le sciècle future. 2, Le véritable conducteur du sciècle future sera celui qui sçaura s'emparer des opinions." It was possible, then, to prepare in his study to "opérer dans le grand pour la postérité." As the result of his studies he attained to a knowledge of the science économique. He wrote and his book was so well received that he saw that he had dis- 
covered his vocation. He became the rallying point for "tous les hommes bienfaisants en ce genre épars jusque la sans se connaître. . . . Enfin, après avoir été longtemps le seul apôtre de cette science je vois maintenant'qu'elle prend force et domination même sur les opinions de tout parti. ... Tout consiste à repandre l'instruction et la lumière. J'ai fait une tentative encore lorsque les Ephémérides sont devenues l'organe de la science et j'ai trouvé à en placer quelques exemplaires en divers cantons de notre province. Maintenant, Monsieur, votre réputation, votre conduite, et votre zèle me flattent de l'idée d'avoir trouve l'homme propre par son mérite, son état, et sa fortune à réalizer en faveur de notre patrie [Provence] ce que je n'ai pu jamais que concevoir en idée, n'ayant ni le crédit, ni les moyens de la faire réussir. Il ne s'agirait pour cela que de répandre la lumière, c'est à dire, d'accoutumer nos compatriotes à s'occuper de ces matières-là. Je vous propose, Monsieur, d'être en cela le bienfaiteur de notre pays et je m'offre à vous pour la correspondance et pour faire passer toutes les secours que vous pourrez désirer à cette égard." He sent him the Précis de l'ordre légal-containing the elements of the science-and the Voyage d'un philosophe, both the work of "M. Poivre, intendant aux Isles de France et de Bourbon. Quant à celui-là, certainement un imprimeur y fera ses affaires. Je dit un imprimeur, car le premier pas utile est d'en prendre un sous votre main et protection, qui soit actif, qui puisse devenir intelligent et qui établisse des correspondances dans les diverses villes de Provence. Comme il faut d'abord le mettre en gout, certainement ce petit receuil, le plus amusant et le plus curieux qu'il soit possible se vendra bien." Raspaud, the man of affairs of the marquis at Aix, had instructions to send him the second part of the Avis au peuple. It had appeared in the Ephémérides and was afterward printed separately. "Cet ouvrage a tellement été jugé utile qu'un grand nombre d'évêques et d'intendants en ont envoyés par centaines dans leurs diocèses et départments." This letter appeared to me so 


\section{Appendix II}

significant a document for the life of the marquis, for the history of the methods employed in revolutionising France, and of the influence of the views of the father upon the thought of the son, that it seemed wise to publish the most important part of it, thus guarding against the possible loss of the original.

\section{APPENDIX II}

Letter of M. de Montvallon, Aix, April 27, I763.

"La mort de la cadette de Marignane a causé un grand désordre de famille. Tous étaient chez Maliverny, lorsqu'à l'heure du dîner, le Comte du Bar [uncle of the child] vint pour prendre la petite qui reste, pour la mener à diner avec sa grand'mère chez lui. La mère s'y opposa avec emportement, et Maliverny, pour calmer sa fille, prit le Comte du Bar par les épaules et le pria de sortir. De quoi le pauvre marquis prit sa fille par le bras en disant que sa fille ni lui ne paraîtraient plus dans cette maison, et, après le dîner, la remit aux Bénédictines.

"Le soir, la jeune marquise envoya demander le bonnet de nuit de son mari, qui dit qu'elle n'avait qu'à revenir; que pour lui, il tiendrait parole. Le lendemain, Maliverny fit prier M. de la Tour, pour finir ce grabuge; il l'avait d'abord promis, et ensuite s'en excusa, sur quoi la marquise, feignant avoir besoin de changer d'air, prit la résolution d'aller à Lyon. Ce qu'il y a d'étrange en tout cela, c'est que les cruautés de la mère contre ses filles, ont fait dire au médecin que, après avoir causé la mort de la cadette, elle causerait celle de l'ainée, si on ne la séparait pas."

De Montvallon.

I have made use of the copy in the manuscript work of M. Mouttet, Mirabeau en Provence, I 2, I3. The original is in the possession of M. L. de Berluc-Perussis of Aix en Provence. 


\section{APPENDIX III}

Letter of Madame de Roquessante, written probably in June, 1772 .

“Depuis ma lettre écrite, le mariage de M. de Mirabeau est enfin conclu. Il faut changer à ce que j'ai eu l'honneur de vous mander qu'au lieu de cent mille écus de fonds, M. de Mirabeau père assure à $M$. son fils les trois terres qu'il a en Provence et à l'époque où le fermier de Mirabeau doit augmenter la ferme de cinq mille francs, il en cède deux et demi à $M$. son fils. Le mariage se fera d'ici à quinze jours ou trois semaines; on attend beaucoup de belle choses de Lyon. On assure même que le père doit envoyer pour vingt mille francs de diamants; il est déjà arrivé au pretenđu une tabatière, une boite à mouche et un étui d'or que l'on dit du meilleur gout possible. On est au comble de la joie. Il est parti sur le champ pour aller prendre Madame sa sœur [Madame de Cabris]; le père permet encore qu'ils habitent Mirabeau tant qu'ils voudront et qu'ils y jouissent du jardin, s'il y en a ou choses pareilles."

The original of this letter is in the possession of $M$. Garcin of Apt en Provence. I have reproduced it from a copy made by $M$. Mouttet.

\section{APPENDIX IV}

Madame Duranti-Ladurane to Citizen Pin. Beaumont, November 29, 1792. From a manuscript copy in the collection of M. Mouttet.

Madame Duranti-Ladurane, the step-daughter of the person who had indorsed one of Mirabeau's notes to the Jews and been obliged to pay it, was attempting to recover from the government the sum that had been paid. After thanking M. Pin for the interest he had taken in the matter, Madame Duranti-Ladurane went on: "Je vous prie de le faire observer dans la pétition que vous prendrez la peine de dresser à cet effect que mon beau-père, qui était fort 


\section{Appendix IV}

attaché à M. Riquetti, fils ainé, et sachant des durétés que son père exercait vis-à-vis de lui, l'ayant marié et ne lui ayant assigné que des biens petits revenus qui ne pouvait pas lui être suffisant, il était obligé de s'endetter" Here follows the portion of the letter given by M. Guibal (i., Io9, note 3). According to Madame Duranti-Ladurane, in the second year of his married life, Mirabeau had recourse to her step-father and painted in such a touching manner his desperate situation-his wife joining her petition to his - that the note was indorsed. When it came due, the marquis was asked to pay it and refused and the Jews forced the payment from the indorser. Five or six years later, in 1783 , when Mirabeau was in Provence for the lawsuit against his wife, the matter was brought to his attention and he was asked to pay. He declared that he was powerless to do so, but that he was an honest man, could never forget the kindness, and would pay as soon as he was able to do so. They never saw him again. "Malheureusement la mort l'a surpris. Nous espérons que la nation, à qui ce grand homme a rendu tant de services, fera honneur à une dette qui certainement lui paraîtra sacrée." Here the extract in Guibal stops. The last two sentences are worthy of reproduction: "Il me semble que ce doit être le bien de ce cruel père qui doit la payer. Il avait, à ce qu'on m'avait dit, déshérité, quoique l'ainé, en faveur de son cadet." 





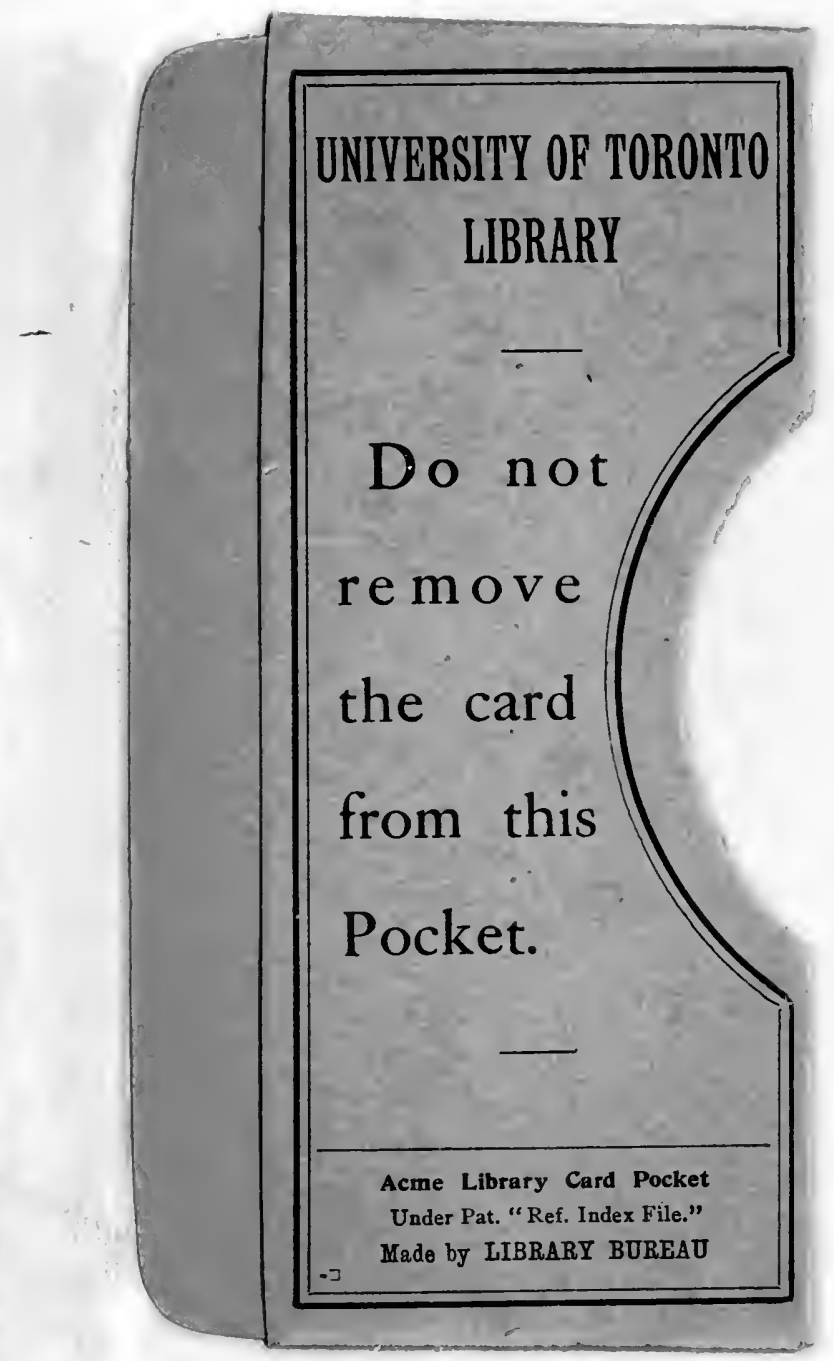




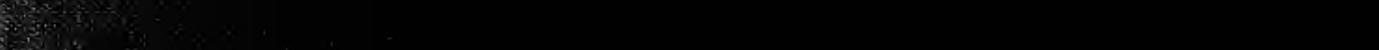

